MARIA FERNANDA BANDEIRA DE MELO GALLETTI

\title{
EFEITOS DA TEMPERATURA E DA ALIMENTAÇÃO SANGUÍNEA SOBRE O PERFIL DE EXPRESSÃO GÊNICA DE Rickettsia rickettsii DURANTE A INFECÇÃO DO CARRAPATO-VETOR Amblyomma aureolatum
}

Tese apresentada ao Programa de Pós-Graduação em Biologia da Relação Patógeno-Hospedeiro do Instituto de Ciências Biomédicas da Universidade de São Paulo para a obtenção do Título de Doutor em Ciências. 


\section{EFEITOS DA TEMPERATURA E DA ALIMENTAÇÃO SANGUÍNEA SOBRE O PERFIL DE EXPRESSÃO GÊNICA DE Rickettsia rickettsii DURANTE A INFECÇÃO DO CARRAPATO-VETOR Amblyomma aureolatum}

Tese apresentada ao Programa de Pós-Graduação em Biologia da Relação Patógeno-Hospedeiro do Instituto de Ciências Biomédicas da Universidade de São Paulo, para a obtenção do Título de Doutor em Ciências.

Área de concentração: Biologia da Relação Patógeno-Hospedeiro

Orientadora: Profa. Dra. Andréa Cristina Fogaça Versão original 
DADOS DE CATALOGAÇÃO NA PUBLICAÇÃO (CIP)

Serviço de Biblioteca e Informação Biomédica do

Instituto de Ciências Biomédicas da Universidade de São Paulo

reprodução não autorizada pelo autor

Galletti, Maria Fernanda Bandeira de Melo.

Efeitos da temperatura e da alimentação sanguínea sobre o perfil de expressão gênica de Rickettsia rickettsii durante a infecção do carrapato-vetor Amblyomma aureolatum / Maria Fernanda Bandeira de Melo Galletti. -- São Paulo, 2013.

Orientador: Profa. Dra. Andréa Cristina Fogaça.

Tese (Doutorado) - Universidade de São Paulo. Instituto de Ciências Biomédicas. Departamento de Parasitologia. Área de concentração:

Biologia da Relação Patógeno-Hospedeiro. Linha de pesquisa: Biologia da interação carrapato-riquétsia.

Versão do título para o inglês: Effects of the temperature and blood feeding on the gene expression profile of Rickettsia rickettsii during infection of its tick vetor Amblyomma aureolatum.

$\begin{array}{llll}\text { 1. Rickettsia rickettsii } & \text { 2. Febre Maculosa } & \text { 3. Carrapato 4. Elevação }\end{array}$ de temperatura 5. Alimentação sanguínea 6. Transcriptoma I. Fogaça, Profa. Dra. Andréa Cristina II. Universidade de São Paulo. Instituto de Ciências Biomédicas. Programa de Pós-Graduação em Biologia da Relação Patógeno-Hospedeiro III. Título. 


\title{
UNIVERSIDADE DE SÃO PAULO \\ INSTITUTO DE CIÊNCIAS BIOMÉDICAS
}

\begin{abstract}
Candidato(a): $\quad$ Maria Fernanda Bandeira de Melo Galletti.
Título da Tese: $\quad$ Efeitos da temperatura e da alimentação sanguínea sobre o perfil de expressão gênica de Rickettsia rickettsii durante a infecção do carrapato-vetor Amblyomma aureolatum.
\end{abstract}

Orientador(a):

Profa. Dra. Andréa Cristina Fogaça.

A Comissão Julgadora dos trabalhos de Defesa da Tese de Doutorado, em sessão pública realizada a considerou
( ) Aprovado(a)
( ) Reprovado(a)

\begin{tabular}{|c|c|}
\hline Examinador(a): & $\begin{array}{l}\text { Assinatura: } \\
\text { Nome: ....... } \\
\text { Instituição: . }\end{array}$ \\
\hline Examinador(a): & $\begin{array}{l}\text { Assinatura: } \\
\text { Nome: ....... } \\
\text { Instituição: }\end{array}$ \\
\hline Examinador(a): & $\begin{array}{l}\text { Assinatura: } \\
\text { Nome: ....... } \\
\text { Instituição: }\end{array}$ \\
\hline Examinador(a): & $\begin{array}{l}\text { Assinatura: } \\
\text { Nome: ........ } \\
\text { Instituição: }\end{array}$ \\
\hline Presidente: & $\begin{array}{l}\text { Assinatura: } \\
\text { Nome: ........ } \\
\text { Instituição: }\end{array}$ \\
\hline
\end{tabular}




\section{CERTIFICADO}

Certificamos que o Projeto intitulado "Caracterização molecular das interações entre o carrapato-vetor e o agente etiológico da febre maculosa, Rickettsia rickettsii", protocolado sob o $\mathrm{n}^{\circ} 1423 / 2008$, utilizando 12 (doze) cobaias, 06 (seis) coelhos e 02 (dois) cães, sob a responsabilidade do Prof. Dr. Marcelo Bahia Labruna, está de acordo com os princípios éticos de experimentação animal da Comissão de Bioética da Faculdade de Medicina Veterinária e Zootecnia da Universidade de São Paulo e foi aprovado na reunião do dia 18 de junho de 2008.

We certify that the Research "Molecular characterization of the interaction between the tick vector and Rickettsia rickettsii, the etiological agent of Brazilian spotted fever", protocol.number 1423/2008, utilizing 12 (twelve) cobaias, 06 (six) habits and 02 (two) dogs, under the responsibility Prof. Dr. Marcelo Bahia Labruna, agree with Ethical Principles in Animal Research adopted by Bioethic Commission of the School of Veterinary Medicine and Animal Science of University of São Paulo and was approved in the meeting of day 06/18/08.

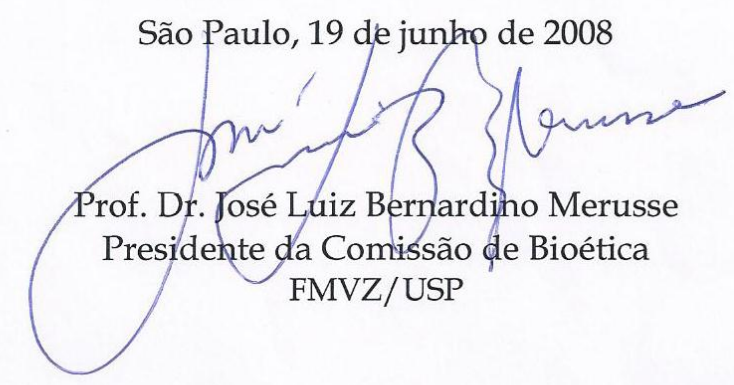




\section{Certificado}

Certificamos que o protocolo registrado sob $n^{\circ} \mathbf{1 2 8}$ nas fls. 109 do livro 02 para uso de animais em experimentação, sob a responsabilidade do Prof(a) $\operatorname{Dr}(a)$ ) Andréa Cristina Fogaça, Coordenador (a) da Linha de pesquisa "Caracterização molecular das interações entre o carrapato-vetor e o agente etiológico da febre maculosa, Rickettsia rickettsii" do qual participam o(s) aluno(s) Maria Fernanda Bandeira de Melo Galletti, Camila Dantas Malossi e os pesquisadores Sirlei Daffre, Marcelo Bahia Labruna, Adriano Pinter, está de acordo com os Princípios Éticos de Experimentação Animal adotado pela Sociedade Brasileira de Ciência de Animais de Laboratório (SBCAL) e foi aprovado pela COMISSÃO DE ÉTICA NO USO DE ANIMAIS (CEUA) em 20.09.2011, com validade de 3 anos.

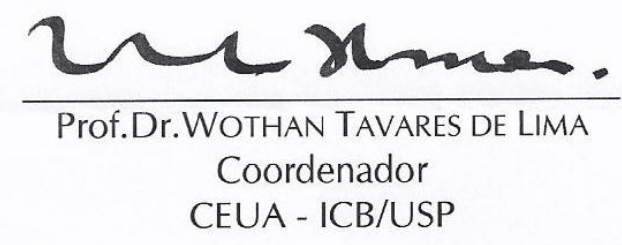

São Paulo, 22 de setembro de 2011.

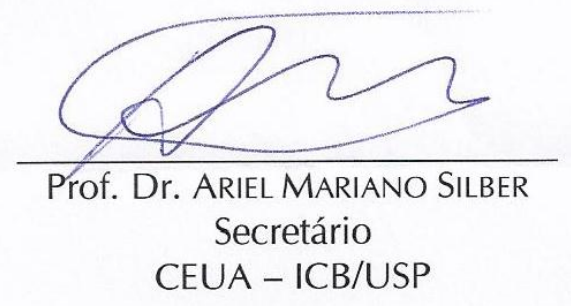


Dedico este trabalho aos meus pais, Aline e José Roberto, que durante toda a vida dedicaram-me amor e apoio irrestrito para a realização de todos os meus sonhos e conquistas.

Ao meu grande amor, meu amado esposo Silvio, pelo apoio incondicional durante todos os momentos dessa jornada.

À minha irmã, Maria Carolina, pelo exemplo de força e caráter.

Eles são os meus exemplos de respeito, capacidade intelectual e profissionalismo. Sem esse apoio eu não estaria preparada para tantos desafios. 


\section{AGRADECIMENTOS}

Confesso que após um longo período de trabalho criativo para compor a tese e seus grandes frutos, me sinto bloqueada para redigir os agradecimentos. Talvez pelo fato de eu me sentir tão grata e maravilhada com tudo que me aconteceu durante o doutoramento. Perdi o fôlego por diversas vezes, por motivos angustiantes ou extremamente bons e novamente fico sem ar, mas desta vez para agradecer. Como dizer a todos o quanto eu reconheço cada ajuda que me foi dada?

Em primeiro lugar, gostaria de agradecer à minha querida orientadora Profa. Dra. Andréa Cristina Fogaça, uma das figuras mais marcantes que conheci. Agradeço a oportunidade de ter desfrutado da sua habilidade intelectual durante todos esses anos. Agradeço também todo o incentivo e estímulo para que eu amadurecesse muito pessoal e profissionalmente. Sempre será um grande exemplo profissional para mim. Agradeço os momentos de paciência, de diabruras experimentais, de devaneios teóricos e de direcionamento ao "planeta terra", quando necessário. Sem o seu apoio, ajuda e dedicação nada disso teria valido a pena.

Às minhas companheiras de grupo, Camila Malossi e Larissa Martins que nos anos de convivência me mostraram como construir uma base sólida de confiança profissional.

À minha co-orientadora Profa. Dra. Sirlei Daffre por todo o aprendizado.

Aos nossos colaboradores diretos, Prof. Dr. Marcelo Labruna e Dr. Adriano Pinter pela dedicação e disposição para contribuir com o trabalho in vivo e Prof. Dr. André Fujita e Dr. Milton Nishiyama por toda a paciência e ajuda estatística.

Aos membros do nosso laboratório, Eliane Esteves, Thaís Bifano, Rafael Rosa, Paula Pohl, Sandra Kalil, Janaina Peixoto, Suzana Pessoa, José Mário Balanco, Claudia Angeli e Gustavo Zoppello pelo apoio diário, dedicação e disposição para contribuir com o meu trabalho.

Ao Departamento de Medicina Veterinária Preventiva e Saúde Animal da Faculdade de Medicina Veterinária e Zootecnia da USP, por todo auxílio durante os experimentos in vivo. 
Ao Departamento de Parasitologia do Instituto de Ciências Biomédicas da USP, pelo apoio estrutural e burocrático.

À Fundação de Amparo à Pesquisa do Estado de SP (FAPESP) e pela concessão da bolsa (2009/50137-7) e apoio financeiro.

Sem o apoio e carinho de todas essas pessoas citadas, além de tantas não mencionadas, essa jornada não teria a mesma importância.

A Deus pela vigilância constante! 
"Toda a nossa ciência, comparada com a realidade, é primitiva e infantil - e, no entanto, é a coisa mais preciosa que temos."

Albert Einstein (1879 - 1955) 


\section{RESUMO}

GALLETTI, M. F. B. M. Efeitos da temperatura e da alimentação sanguínea sobre o perfil de expressão gênica de Rickettsia rickettsii durante a infecção do carrapato-vetor Amblyomma aureolatum. 2013. 148 f. Tese (Doutorado em Biologia da Relação Patógeno-Hospedeiro) - Universidade de São Paulo, Instituto de Ciências Biomédicas, São Paulo, 2013.

Rickettsia rickettsii é o agente etiológico da febre maculosa das Montanhas Rochosas, a mais letal dentre as riquetsioses que acometem o homem. A principal espécie de carrapato-vetor de $R$. rickettsii na área metropolitana da cidade de São Paulo é Amblyomma aureolatum. Quando um carrapato em jejum no solo encontra um hospedeiro vertebrado e inicia a alimentação sanguínea, $R$. rickettsii é exposta a uma elevação da temperatura e aos componentes da refeição sanguínea. Ambos os estímulos foram previamente associados à reativação da virulência da bactéria em carrapatos, porém, os fatores responsáveis por essa conversão do fenótipo avirulento em virulento não foram completamente elucidados até o momento. Dessa forma, o presente trabalho teve como objetivo determinar os efeitos desses dois estímulos ambientais sobre o perfil de expressão gênica dessa bactéria durante a infecção de $A$. aureolatum. Inicialmente, estabelecemos um sistema de propagação de riquétsias para obter material genético suficiente para a padronização dos procedimentos de preparação de amostras para os experimentos de microarranjos. Para tal, estabelecemos, pela primeira vez, a infecção de uma cepa patogênica brasileira de $R$. rickettsii em células embrionárias do carrapato Rhipicephalus (Boophilus) microplus (BME26). Através da utilização de microarranjos de oligonucleotídeos customizados, analisamos os efeitos da elevação da temperatura em $10^{\circ} \mathrm{C}$ e da alimentação sanguínea sobre o perfil transcricional da bactéria infectando o conjunto de órgãos de fêmeas de $A$. aureolatum. Esse é o primeiro estudo da expressão gênica global de uma bactéria do gênero Rickettsia infectando um carrapato-vetor natural. Apesar de ambos os estímulos terem promovido um aumento da carga bacteriana, a alimentação sanguínea teve um efeito maior, também modulando cinco vezes mais genes que a elevação da temperatura. Dentre os genes induzidos, alguns codificam fatores de virulência, tais como componentes do sistema de secreção do tipo IV (T4SS), sugerindo que esse importante sistema de secreção bacteriano seja utilizado para secretar efetores durante a ingestão de sangue pelo carrapato. Através de análises in silico de domínios conservados das proteínas hipotéticas, identificamos outros componentes do T4SS de $R$. rickettsii ainda não descritos na literatura. A alimentação sanguínea também induziu a expressão de genes codificadores de enzimas antioxidantes, o que pode corresponder a uma tentativa de $R$. rickettsii de se proteger contra os efeitos deletérios de radicais livres produzidos pelos carrapatos alimentados. Por fim, analisamos a transcrição de uma seleção de genes de $R$. rickettsii em glândulas salivares e intestinos de carrapatos machos e fêmeas através de RT-qPCR microfluídica. Os resultados mostraram que a elevação da temperatura e a alimentação modulam um conjunto específico de genes em cada tecido analisado, tendo sido possível definirem-se assinaturas transcricionais tecido-específicas. Os genes diferencialmente expressos identificados neste estudo devem ser caracterizados funcionalmente, podendo ser considerados como futuros alvos para o desenvolvimento de vacinas. 
Palavras-chave: Rickettsia rickettsii. Febre Maculosa. Carrapato. Elevação de temperatura. Alimentação sanguínea. Transcriptoma. Microarranjos. RT-qPCR. Assinatura transcricional. 


\begin{abstract}
GALLETTI, M. F. B. M. Effects of the temperature and blood feeding on the gene expression profile of Rickettsia rickettsii during infection of its tick vector Amblyomma aureolatum. 2013. 148 p. Ph. D. thesis (Doctorate in Biology of HostPathogen Relation) - University of São Paulo, Institute of Biomedical Sciences, São Paulo, 2013.
\end{abstract}

Rickettsia rickettsii is the causative agent of Rocky Mountain Spotted Fever, which is the most lethal spotted fever rickettsiosis that affects humans. The main tick species that transmits $R$. rickettsii in the metropolitan area of São Paulo's city is Amblyomma aureolatum. When an infected and starving tick begins blood feeding from a vertebrate host, $R$. rickettsii is exposed to a temperature elevation and to components in the blood meal. These two environmental stimuli have been previously associated with the reactivation of rickettsial virulence in ticks, but the factors responsible for this phenotype conversion have not been completely elucidated. The main aim of the present work was to determine the effects of these two environmental stimuli on the $R$. rickettsii transcriptional profile during $A$. aureolatum infection. We initially established an effective system for rickettsia propagation to generate a substantial quantity of genetic material for microarray standardization. For that, for the first time, we established an in vitro infection of the virulent Brazilian $R$. rickettsii strain in the BME26 tick embryonic cell line from Rhipicephalus (Boophilus) microplus. Using customized oligonucleotide microarrays, we analyzed the effects of a $10^{\circ} \mathrm{C}$ temperature elevation and a blood meal on the transcriptional profile of $R$. rickettsii infecting whole organs of Amblyomma aureolatum female ticks. This is the first bacterial transcriptome study of the Rickettsia genus when infecting a natural tick vector. Although both stimuli significantly increased the bacterial load, blood feeding had a greater effect, also modulating five-fold more genes than the temperature upshift. Among the genes induced by blood-feeding, some encode virulence factors, such as Type IV Secretion System (T4SS) components, suggesting that this important bacterial transport system is used to secrete effectors during the acquisition of the blood meal by the tick. Using an in silico conserved domain analysis of hypothetical proteins, we identified additional T4SS components of $R$. rickettsii that were never previously described. Blood-feeding also up-regulated the expression of antioxidant enzymes, which might correspond to an attempt by $R$. rickettsii to protect itself against the deleterious effects of free radicals produced by fed ticks. Finally, we studied the transcriptional profile of selected genes of $R$. rickettsii on the salivary glands and midguts of male and female ticks by microfluidic RT-qPCR. Results showed that temperature upshift and blood feeding modulate specific sets of genes in each tissue, allowing for the establishment of a tissue-specific transcriptional signature. The modulated genes identified in this study require further functional analysis and may have potential as future targets for vaccine development.

Keywords: Rickettsia rickettsii. Rocky Mountain Spotted Fever. Tick. Elevation of temperature. Blood feeding. Transcriptome. Microarray. RT-qPCR. Transcriptional signature. 


\section{LISTA DE ILUSTRAÇÕES}

Figura 1 - llustração da infecção de carrapatos ixodídeos por $R$. rickettsii e da transmissão da bactéria para o hospedeiro vertebrado

Figura 2 - Fluxograma dos quatro diferentes procedimentos utilizados para a preparação das amostras de cDNA para a hibridização nos microarranjos......41

Figura 3 - Observação de células BME26 infectadas com $R$. rickettsii por microscopia ótica.

Figura 4 - Curva de crescimento de $R$. rickettsii em células BME26. .52

Figura 5 - Imagem gerada pelo escaneamento dos microarranjos de oligonucleotídeos após a hibridização com amostras de cDNA de $R$. rickettsii preparadas com diferentes procedimentos.

Figura 6 - Níveis de infecção em órgãos totais de carrapatos A. aureolatum adultos.

Figura 7 - Classificação funcional das CDS de R. rickettsii moduladas pelo aumento da temperatura de incubação de $25{ }^{\circ} \mathrm{C}$ para $35{ }^{\circ} \mathrm{C}$ durante a infecção de fêmeas de $A$. aureolatum.

Figura 8 - Classificação funcional das CDS de $R$. rickettsii moduladas pela alimentação sanguínea de fêmeas de $A$. aureolatum infectadas

Figura 9 - Efeitos da temperatura sobre o perfil de expressão gênica de $\boldsymbol{R}$. rickettsii infectando glândulas salivares (SG) e intestinos (MG) de machos e fêmeas de $A$. aureolatum.

Figura 10 - Assinatura gênica tecido-específica de $R$. rickettsii quando exposta à elevação da temperatura em $10^{\circ} \mathrm{C}$.

Figura 11 - Efeitos da alimentação sanguínea sobre o perfil de expressão gênica de $R$. rickettsii infectando glândulas salivares (SG) e intestinos (MG) de machos e fêmeas de $A$. aureolatum.

Figura 12 - Assinatura gênica tecido-específica de R. rickettsii quando exposta à alimentação sanguínea.

Figura 13 - Assinatura gênica tecido-específica de $R$. rickettsii exposta à elevação da temperatura e à alimentação sanguínea simultaneamente.

Figura 14 - Localização e orientação dos genes codificadores de componentes do T4SS reprimidos (A) ou induzidos (B) pela alimentação sanguínea no cromossomo de $R$. rickettsii. 


\section{LISTA DE TABELAS}

Tabela 1 - Programa térmico das qPCR realizadas no equipamento BioMark (Fluidigm Corporation)

Tabela 2 - CDS de $R$. rickettsii com função anotada moduladas pela elevação da temperatura de incubação do carrapato vetor de $25^{\circ} \mathrm{C}$ para $35^{\circ} \mathrm{C}$ .58

Tabela 3 - CDS de $R$. rickettsii com função anotada induzidas pela alimentação sanguínea do carrapato

Tabela 4 - CDS de $R$. rickettsii com função anotada reprimidas pela alimentação sanguínea do carrapato

Tabela 5 - Análise de similaridade de proteínas hipotéticas moduladas pelo aumento de temperatura de incubação de $25^{\circ} \mathrm{C}$ a $35^{\circ} \mathrm{C}$.

Tabela 6 - Análise de similaridade de proteínas hipotéticas induzidas pela alimentação sanguínea

Tabela 7 - Análise de similaridade de proteínas hipotéticas reprimidas pela alimentação sanguínea.

Tabela 8 - Validação dos dados de modulação dos microarranjos por RT-qPCR. ..69

Tabela 9 - CDS de $R$. rickettsii diferencialmente expressas pela exposição à elevação de temperatura em tecidos de $A$. aureolatum adultos. A análise transcricional foi realizada por RT-qPCR microfluídica

Tabela 10 - CDS de $R$. rickettsii diferencialmente expressas pela exposição à alimentação sanguínea nas glândulas salivares de $A$. aureolatum adultos.

Tabela 11 - CDS de $R$. rickettsii diferencialmente expressas pela exposição à alimentação sanguínea nos intestinos de $A$. aureolatum adultos

Tabela 12 - CDS de $R$. rickettsii diferencialmente expressas nas glândulas salivares de $A$. aureolatum adultos pelo efeito aditivo da elevação de temperatura e da alimentação sanguínea. 82

Tabela 13 - CDS de $R$. rickettsii diferencialmente expressas no intestino de $A$. aureolatum adultos pelo efeito aditivo da elevação de temperatura e da alimentação sanguínea.

Tabela 14 - CDS de $R$. rickettsii expressas em células BME26 incubadas a $34{ }^{\circ} \mathrm{C}$. 


\section{LISTA DE ABREVIATURAS E SIGLAS}

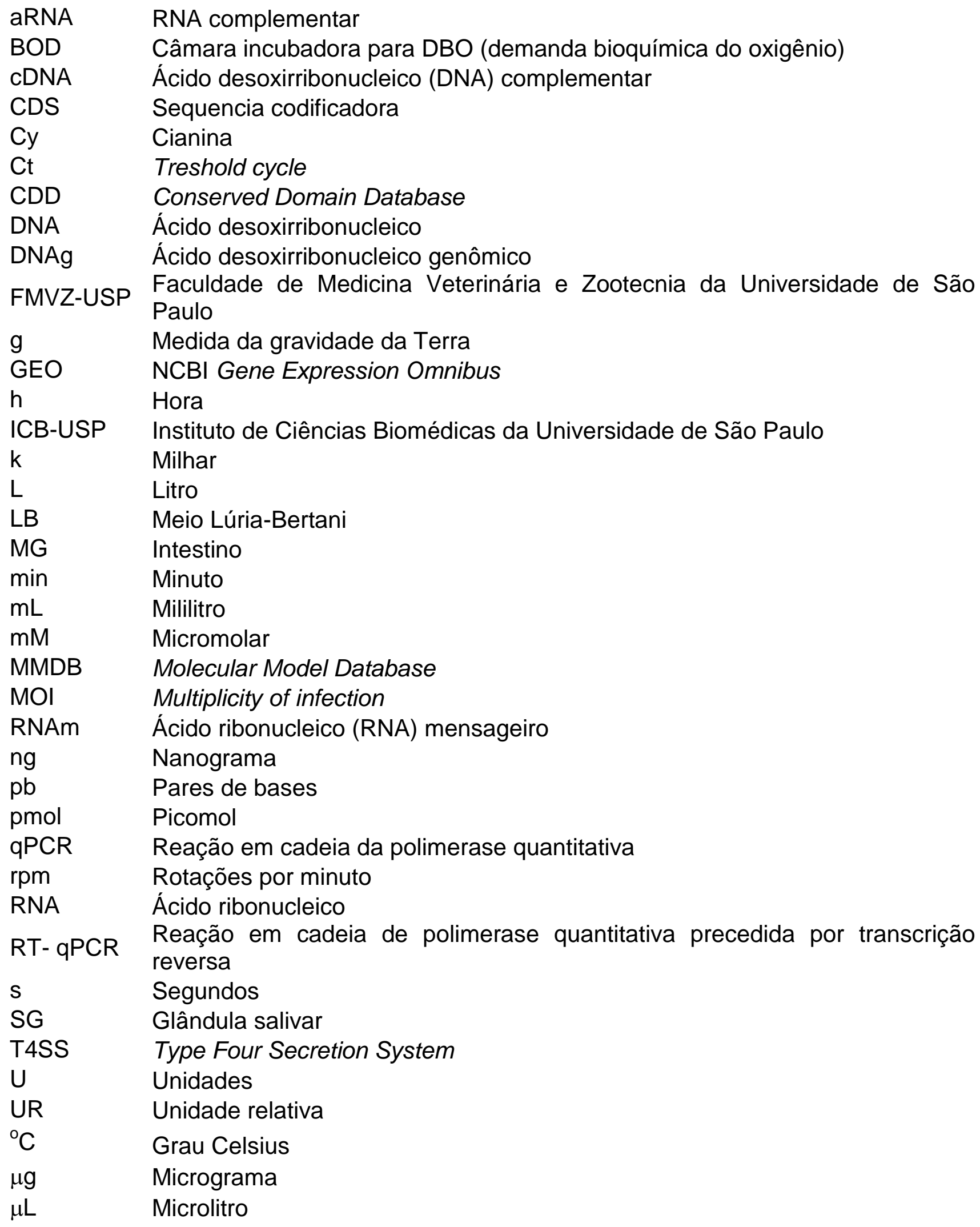


1 INTRODUÇÃO

1.1 Carrapatos e sua importância na transmissão de agentes infecciosos.......19

1.2 Febre Maculosa das Montanhas Rochosas (RMSF) ................................21

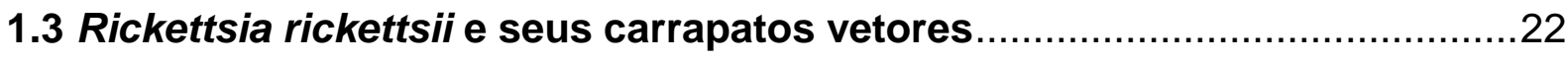

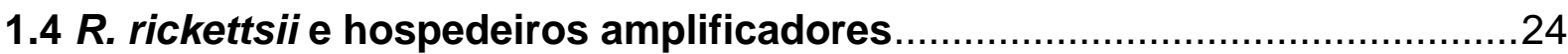

1.5 Estudos moleculares da interação entre carrapatos e patógenos por eles

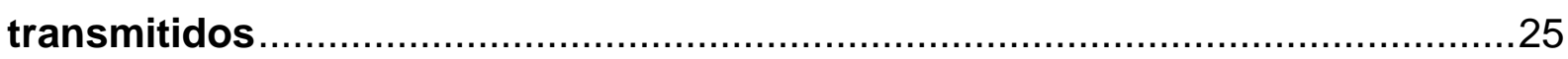

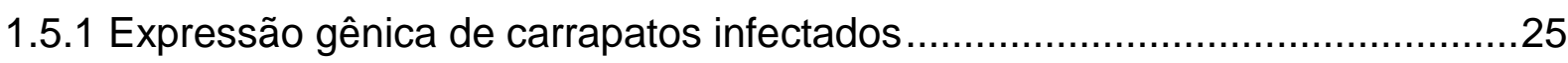

1.5.2 Reativação da virulência de riquétsias durante a infecção do carrapato-vetor e expressão gênica frente a diferentes condições ambientais ..................................27

2 OBJETIVO

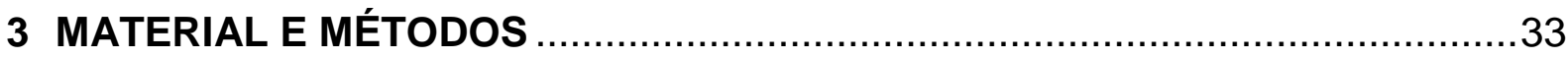

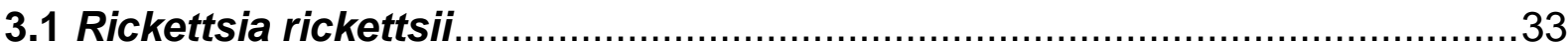

3.2 Células embrionárias do carrapato Rhipicephalus (Boophilus) microplus

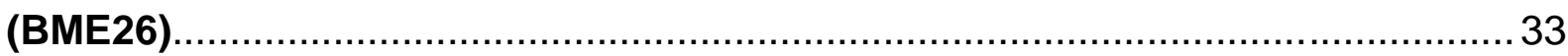

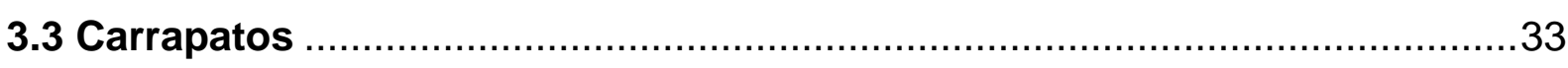

3.4 Infecção experimental de células BME26 por R. rickettsii...........................34

3.4.1 Determinação da curva de crescimento de Rickettsia rickettsii em células embrionárias de carrapatos .............................................................................

3.5 Infecção experimental de $\boldsymbol{A}$. aureolatum por $\boldsymbol{R}$. rickettsii............................36

3.6 Dissecção das glândulas salivares e intestinos de $A$. aureolatum infectados

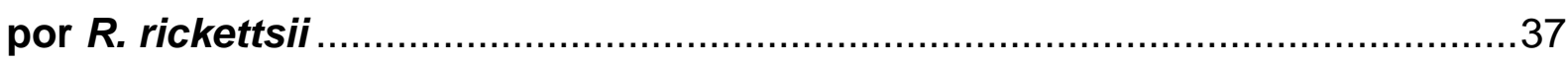

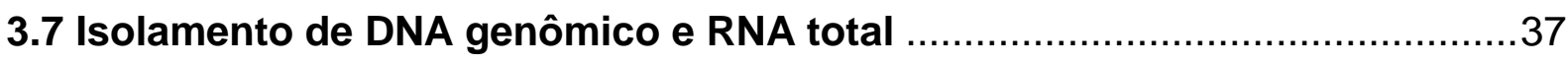

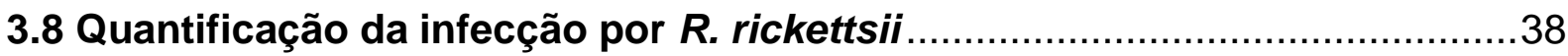

3.8.1 Clonagem de um fragmento de $147 \mathrm{pb}$ do gene da citrato sintase (gltA) de Rickettsia spp..............................................................................................

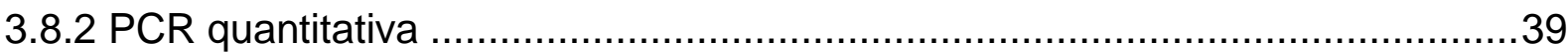

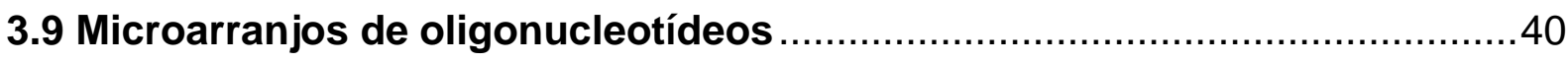

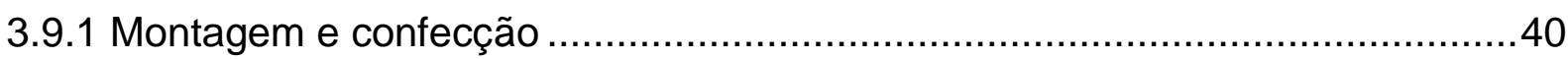

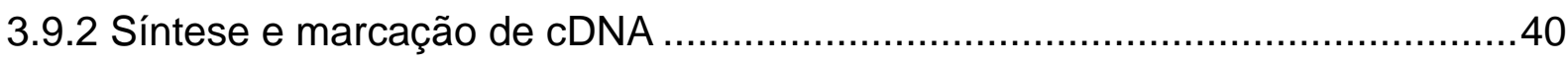

3.9.2.1 Padronização dos procedimentos .......................................................... 40 
3.9.2.2 Amostras destinadas à determinação da expressão gênica diferencial de $R$. rickettsii.

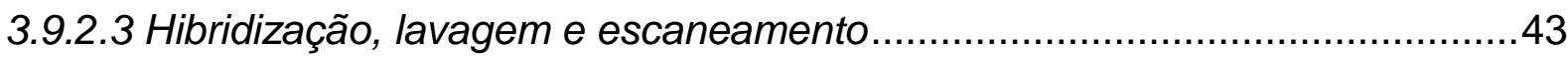

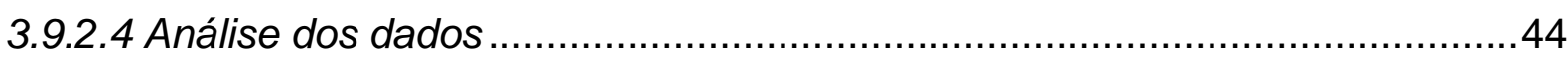

3.10 Análise in silico das CDS de proteínas moduladas pela temperatura e alimentação sanguínea

3.11 Validação dos dados de microarranjos por reação em cadeia de polimerase quantitativa precedida por transcrição reversa (RT- qPCR) ............45

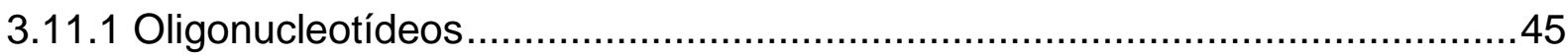

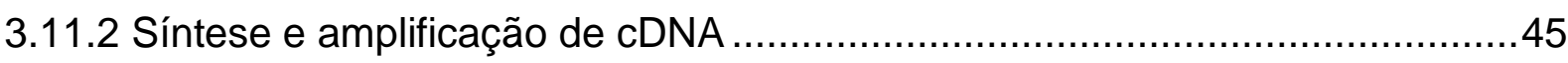

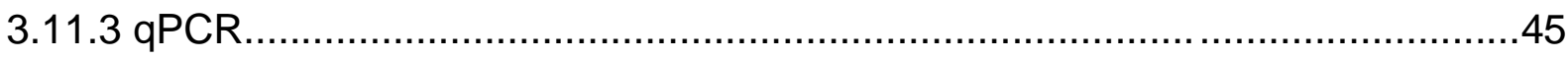

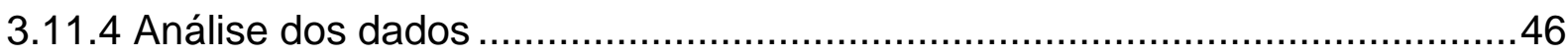

3.12 Análise do perfil de expressão gênica de $R$. rickettsii em glândulas salivares e intestinos de carrapatos adultos por RT- qPCR microfluídica .........46

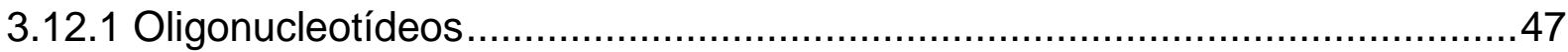

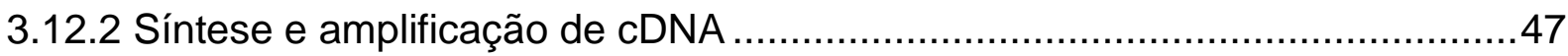

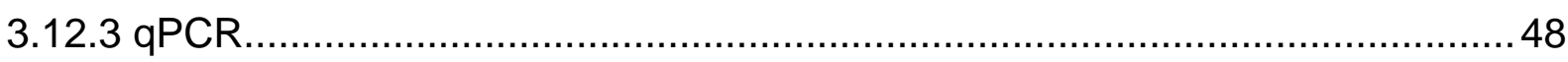

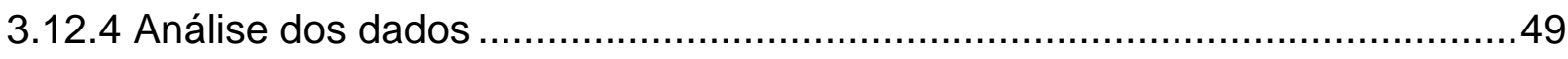

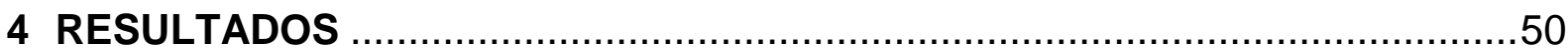

4.1 Determinação do perfil de expressão gênica global de Rickettsia rickettsii por microarranjos de oligonucleotídeos ......................................................

4.1.1 Padronização dos procedimentos para a síntese e marcação de cDNA ..........50

4.2 Efeitos de estímulos ambientais sobre o perfil transcricional de $R$. rickettsii infectando carrapatos Amblyomma aureolatum ..............................................54

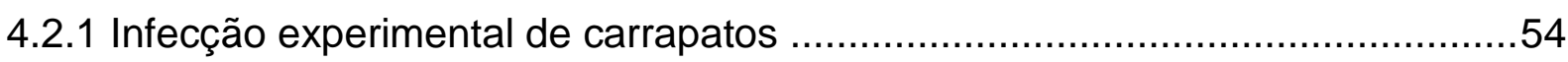

4.2.2 Efeitos da temperatura sobre o perfil de expressão gênica global de $R$.

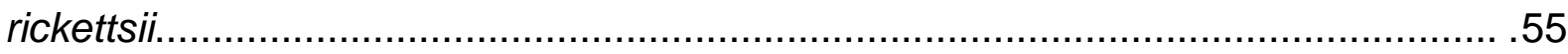

4.2.3 Determinação dos efeitos da alimentação sobre o perfil de expressão gênica global de $R$. rickettsii

4.3 Caracterização in silico das proteínas hipotéticas moduladas pela temperatura e alimentação sanguínea .65

4.4 Confirmação do perfil de expressão de $R$. rickettsii infectando fêmeas de $A$. aureolatum 
4.5 Perfil de expressão de genes de $\boldsymbol{R}$. rickettsii modulados pela temperatura e alimentação sanguínea em glândulas salivares e intestinos de carrapatos $\boldsymbol{A}$.

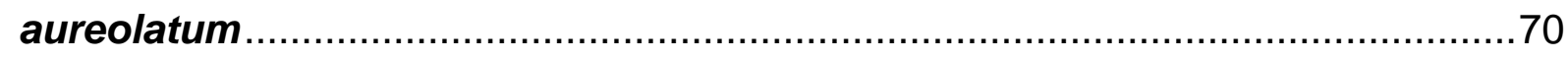

4.6 Expressão gênica de $\boldsymbol{R}$. rickettsii em células BME26 ...............................84

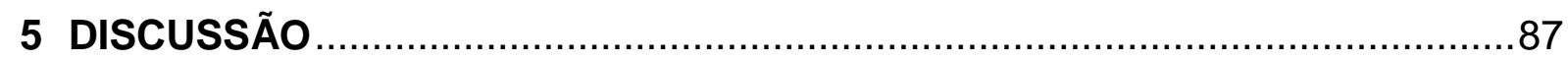

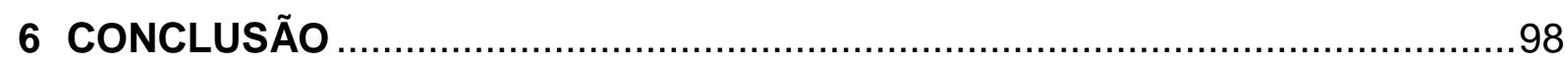

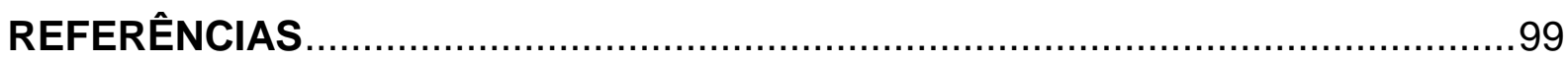

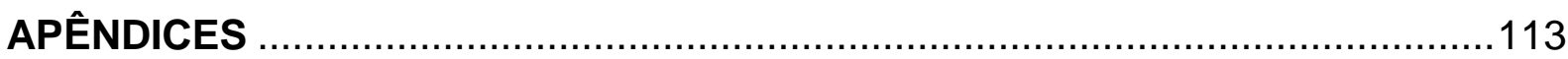

APÊNDICE A - Oligonucleotídeos utilizados na validação dos dados de expressão gênica de $R$. rickettsii obtidos nos microarranjos.

APÊNDICE B - Oligonucleotídeos utilizados na validação dos dados de expressão gênica de $R$. rickettsii obtidos nos microarranjos.

APÊNDICE C - Proteínas hipotéticas de $R$. rickettsii moduladas pela mudança de temperatura em $10^{\circ} \mathrm{C}$.

APÊNDICE D - Proteínas hipotéticas de $R$. rickettsii induzidas pela alimentação sanguínea.

APÊNDICE E - Proteínas hipotéticas de $R$. rickettsii reprimidas pela alimentação sanguínea. 


\section{INTRODUÇÃO}

\subsection{Carrapatos e sua importância na transmissão de agentes infecciosos}

Os carrapatos são artrópodes que apresentam um hábito de vida parasitário, alimentando-se obrigatoriamente do sangue e/ou da linfa de animais vertebrados. Além do desconforto e lesões ocasionadas pela picada, o hospedeiro pode ser acometido por paralisia e, no caso de grandes infestações, anemia (Sonenshine, 1991). Além disso, os carrapatos são vetores de uma ampla diversidade de patógenos como vírus, bactérias e protozoários, os quais, por sua vez, podem ocasionar doenças severas tanto ao homem quanto a outros animais (Colwell et al., 2011; Dantas-Torres et al., 2012; Jongejan, Uilenberg, 2004; Nicholson et al., 2010; Piesman, Eisen, 2008; Sonenshine, 1991).

Esses ectoparasitas estão subdivididos em três famílias: Nuttalliellidae, Argasidae e Ixodidae. (Horak et al., 2002; Keirans, Durden, 2001; Nava et al., 2009). A família Nuttalliellidae é a menor descrita, representada por apenas um gênero de carrapatos, Nuttalliella, com pouca descrição e estudos reportados na literatura (Horak et al., 2002; Latif et al., 2012; Mans et al., 2012). Diferentemente, mais de 900 espécies das famílias Argasidae e Ixodidae, já foram descritas (Nava et al., 2009). Os membros dessas duas últimas famílias se diferenciam por inúmeras características metabólicas e morfológicas (Barker, Murell, 2004). Carrapatos argasídeos têm como característica a ausência de um escudo dorsal quitinoso e, por isso, são conhecidos como "carrapatos moles". Têm fases de vida parasitária curtas (de minutos a algumas horas) e podem permanecer por longos períodos no ambiente, mesmo sob condições hostis, sem se alimentar. Além disso, apresentam estádios de ovo, larva, vários estádios de ninfa (de dois a oito) e, no estádio adulto, realizam várias cópulas e ovipõem uma pequena coleção de ovos (algumas centenas) após cada repasto sanguíneo (Kopacek et al., 2010). Dois gêneros são comumente associados a infestações de humanos e animais, Argas e Ornithodoros, responsáveis também pela disseminação de vírus e, principalmente, de bactérias do gênero Borrelia (Dantas-Torres et al., 2012; Keirans, Durden, 2001). Já os carrapatos ixodídeos possuem tipicamente três estádios de desenvolvimento (larva, ninfa e adultos) e, em sua maioria, dependem da alimentação em três hospedeiros para completar esse ciclo de vida. No estádio adulto, a diferenciação em gêneros é 
realizada facilmente através da presença de um escudo quitinoso dorsal completo nos machos e parcial nas fêmeas, dando origem ao nome "carrapatos duros". Diferentemente dos argasídeos, carrapatos ixodídeos alimentam-se por períodos mais longos, de até três semanas. A fase parasitária é apenas finalizada após o completo ingurgitamento e desprendimento da pele do hospedeiro (Klompen et al., 1996; Mans, Neitz, 2004). Em virtude deste prolongado período de alimentação, os membros da família Ixodidae são vetores de uma grande diversidade de agentes patogênicos (Colwell et al., 2011; Jongejan, Uilenberg, 2004). De fato, nesta família encontram-se diversos gêneros de importância médica humana e veterinária e/ou que acarretam prejuízos econômicos significativos (Dantas-Torres et al., 2012).

As viroses transmitidas por carrapatos que usualmente acometem humanos são divididas em três grupos de acordo com as manifestações clínicas da doença: (i) o grupo das encefalites (Encefalite de Powassan, Encefalite Langat, Encefalite Louping III); (ii) o grupo das febres hemorrágicas (Febre hemorrágica de Omsk, Doença da floresta de Kyasanur e Febre hemorrágica do Congo-Crimeia) e; (iii) o grupo das viroses similares à dengue (Dobler, 2010; Kilpatrick, Randolph, 2012; Piesman, Eisen, 2008). Embora possuam manifestações clínicas distintas, muitas destas doenças são ocasionadas pela mesma família de vírus (Flaviviridae) e possuem em comum um alto grau de letalidade, em torno de 30\% (Lasala, Holbrook, 2010).

Diferentemente da grande diversidade de vírus transmitidos por carrapatos, poucos são os protozoários carregados por eles. Ainda assim, o principal representante deste grupo, protozoários do gênero Babesia, são altamente patogênicos e acometem tanto humanos quanto outros animais. As babesioses estão distribuídas em todos os continentes. No caso da babesiose bovina, prejuízos pecuários significativos são ocasionados em decorrência da diminuição da produtividade (queda na produção de leite e diminuição do ganho de peso) e aumento da mortalidade no rebanho (Barros et al., 2005; Böse et al., 1995; Suarez, Noh, 2011). A patologia é ainda uma preocupação médico-sanitária, já que, além da transmissão por carrapatos, o patógeno pode ainda ser transmitido via transfusão sanguínea (Schnittger et al., 2012).

Além de vírus e protozoários, as bactérias se destacam como importantes agentes infecciosos transmitidos por carrapatos, com grande impacto socioeconômico. As bactérias transmitidas por carrapatos são subdivididas 
essencialmente em quatro grupos, (i) bacilos Gram-negativos, causadores da Tularemia; (ii) erlichias, agentes etiológicos das erlichiose monocítica e erlichiose granulocítica humana; (iii) espiroquetas (borrélias), agentes etiológicos das doença de Lyme e da febre recorrente transmitida por carrapato e, por fim, (iv) riquétsias, causadoras das febres maculosas, com grande potencial fatal (Dantas-Torres et al., 2012; Parola, Raoult, 2006).

\subsection{Febre Maculosa das Montanhas Rochosas (RMSF)}

Dentre as riquettsioses transmitidas por carrapatos, a Febre Maculosa das Montanhas Rochosas (Rock Mountain Spotted Fever; RMSF) é a mais severa. A RMSF está amplamente distribuída por diversos países do continente Americano, com casos reportados no Canadá, Estados Unidos (Chapman et al., 2006), México (Zavala-Castro et al., 2006), Costa Rica (Fuentes, 1979; Hun et al., 2008), Panamá (Estripeaut et al., 2007), Colômbia (Hidalgo et al., 2007), Argentina (Paddock et al., 2008; Ripoll et al., 1999) e Brasil (Angerami et al., 2006a, b; Calic et al., 2005; de Lemos et al., 2002). No Brasil, a doença é conhecida como Febre Maculosa Brasileira (FMB) (Labruna, 2009).

A RMSF é uma riquetsiose que acomete o homem e tem desenvolvimento potencialmente fatal (Dantas-Torres, 2007; Nicholson et al., 2010). A doença foi divulgada cientificamente por Wolbach (1919). Na fase inicial, a sintomatologia é caracterizada por uma febre alta repentina, náuseas e vômito. Com a progressão da enfermidade, é possível detectar-se dores musculares e abdominais intensas e, em $60-70 \%$ dos casos, podem-se visualizar máculas na superfície corporal, as quais nomeiam a doença (Chapman et al., 2006; Greene, Breitschwerdt, 2006; DantasTorres, 2007). A antibioticoterapia específica, a base de tetraciclina e cloranfenicol, pode ser bem sucedida se iniciada imediatamente após a detecção da doença. Entretanto, devido à grande similaridade sintomática com outras doenças mais comuns e a vasta possibilidade de diagnósticos diferenciais, ocorre um retardo do início do tratamento, podendo levar o paciente a óbito (Dantas-Torres, 2007).

No Brasil, a FMB já foi registrada em diversos estados da região Nordeste, Sul, Centro-Oeste, sendo que a maior incidência, com áreas endêmicas, ocorre na região Sudeste. As taxas de letalidade nessas áreas endêmicas oscilam entre 22 e 42\%, de acordo com os dados do Ministério da Saúde <http://portal.saude.gov.br/ 
portal/saude/profissional/area.cfm?id_area=1555>. Somente no Estado de São Paulo, 410 casos foram confirmados laboratorialmente entre 2001 e 2011, sendo que 152 (37,07\%) destes foram fatais (Divisão de Zoonoses do Centro de Vigilância Epidemiológica de SP <http://www.cve.saude.sp.gov.br/htm/cve_fmb.html>. Em 2011, 19 óbitos decorrentes de FMB foram registrados pelo Ministério da Saúde em São Paulo <http://portal.saude.gov.br/portal/arquivos/pdf/obitos_febre_maculosa_ brasil_1990_2011.pdf>.

\subsection{Rickettsia rickettsii e seus carrapatos vetores}

O agente etiológico da RMSF é a a-proteobactéria intracelular obrigatória, Rickettsia rickettsii (Família Rickettsiaceae; Ordem Rickettsiales), a qual é aeróbia, não possui motilidade, nem forma esporos (Hackstadt, 1996; Weiss, 1982). Estes organismos unicelulares têm entre 0,3 e $2 \mu \mathrm{m}$ de tamanho e possuem uma membrana externa composta por lipopolissacarídeos em sua maioria (Hackstadt, 1996).

A distribuição de $R$. rickettsii está restrita ao continente Americano (Chapman et al., 2006) e pode ser correlacionada a presença de diferentes espécies de carrapatos da Família Ixodidae, seus carrapatos vetores (Chapman et al., 2006; Dantas-Torres 2007; Dantas-Torres et al., 2012; Demma et al., 2005; Labruna, 2009). Os carrapatos, então, atuam tanto como reservatórios de $R$. rickettsii, quanto como transmissores da mesma para diferentes espécies de animais e para o homem (Parola et al., 2005). Nos Estados Unidos, os carrapatos Dermacentor variabilis e Dermacentor andersoni são descritos como principais vetores da bactéria, enquanto no México e em parte do estado americano do Arizona, é o carrapato Rhipicephalus sanguineus. Ainda nos EUA, o carrapato Amblyomma americanum já foi apontado como vetor no estado da Carolina do Norte (para revisão, vide Dantas-Torres et al., 2012). Ao longo de parte da América Central e toda a América do Sul, incluindo o Brasil, o carrapato Amblyomma cajennense (carrapato-estrela), que apresenta uma resistência considerável aos ambientes inóspitos das regiões áridas e diferentes condições de umidade das áreas temperadas (Estrada-Peña et al., 2004; Szabó et al., 2013), é incriminado como principal vetor (Chapman et al., 2006). Essa espécie também é a principal transmissora de $R$. rickettsii no Brasil, onde está amplamente distribuída (Labruna, 2009). Entretanto, na região metropolitana do estado de São 
Paulo, o carrapato Amblyomma aureolatum (carrapato amarelo-do-cão) é reconhecido como principal vetor devido às condições ideais (temperatura amena e umidade elevada) para sua proliferação (Labruna, 2009; Labruna et al., 2011; Pinter \& Labruna, 2006; Vieira et al., 2004).

Após a ingestão de sangue de um hospedeiro vertebrado infectado, o epitélio intestinal de seu carrapato-vetor é colonizado por $R$. rickettsii, onde a bactéria é amplificada. Em seguida, praticamente todos os tecidos do carrapato são infectados, inclusive as glândulas salivares e os ovários (Figura 1). Assim, a bactéria pode ser transmitida da mãe para a prole (transmissão transovariana). Além disso, ocorre transmissão de um estádio para outro, caracterizando uma transmissão transestadial (Burgdorfer, 1988; Labruna et al., 2011; Soares et al., 2012). Intrigantemente, os diferentes tipos de transmissão parecem não ser suficientes para manter altas taxas de prevalência da bactéria nas populações naturais de carrapatos. Segundo estudos de campo realizados nos Estados Unidos e também no Brasil, somente uma pequena parcela de carrapatos encontra-se infectada por $R$. rickettsii nas áreas endêmicas para a RMSF (Burgdorfer, 1988; Foley et al., 2007; Guedes et al., 2005; Labruna, 2009; Ogrzewalska et al., 2012; Pinter, Labruna, 2006; Sangioni et al., 2005). No Brasil, foi relatada uma taxa de apenas $0,89 \%$ de infecção em uma população de $A$. aureolatum de Mogi das Cruzes (Pinter, Labruna, 2006) e de 11\% na população da mesma espécie de carrapato em São Bernardo do Campo (Ogrzewalska et al., 2012), ambas as cidades do estado de São Paulo. Segundo Burgdorfer (1988) e Niebylski e colaboradores (1999), a baixa prevalência de indivíduos infectados nas populações naturais de carrapatos, mesmo em regiões endêmicas, pode ser associada a menores taxas reprodutivas e de sobrevivência, já que os estudos desses autores sugeriram que $R$. rickettsii é patogênica para seus vetores nos Estados Unidos. No Brasil, estudos também apontaram uma diminuição nos parâmetros reprodutivos e de sobrevivência de carrapatos do gênero Amblyomma infectados por $R$. rickettsii (Labruna et al., 2011; Soares et al., 2012).

Sendo assim, a caracterização molecular das interações entre $A$. aureolatum e a bactéria $R$. rickettsii faz-se importante, podendo gerar informações relevantes para o esclarecimento dos mecanismos de virulência de Rickettsia para carrapatos. Esses dados, por sua vez, podem gerar subsídios para um melhor entendimento dos mecanismos responsáveis pela baixa prevalência da bactéria nas populações naturais de $A$. aureolatum. 
Figura 1 - llustração da infecção de carrapatos ixodídeos por $\boldsymbol{R}$. rickettsii e da transmissão da bactéria para o hospedeiro vertebrado.

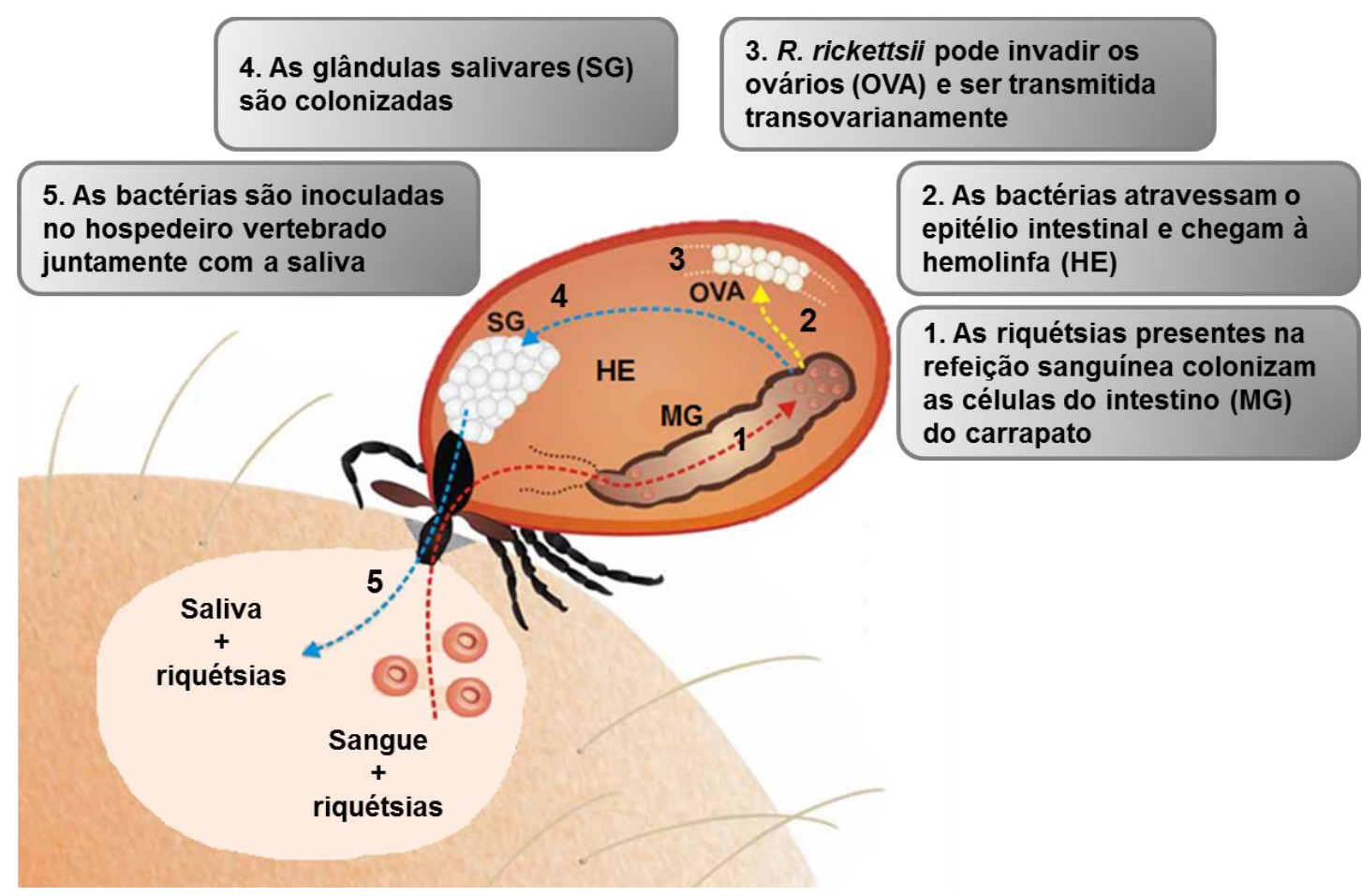

Fonte: Modificado de Hajdušek e colaboradores (2013).

\subsection{R. rickettsii e hospedeiros amplificadores}

Devido às baixas taxas de prevalência de carrapatos infectados por $R$. rickettsii em áreas endêmicas, a participação de alguns animais vertebrados silvestres como hospedeiros amplificadores tem grande relevância epidemiológica. Estes animais mantêm a bactéria em níveis altos em sua corrente sanguínea por alguns dias ou semanas após a infecção, garantindo a fonte de infecção para carrapatos na natureza (Burgdorfer, 1988; Labruna, 2009; Souza et al., 2009). No Brasil, as capivaras, gambás e cães domésticos são apontados como potenciais hospedeiros amplificadores de $R$. rickettsii (Labruna, 2009; Ogrzewalska et al., 2012). Além disso, estes hospedeiros também possibilitam uma elevação da densidade populacional dos carrapatos.

No entanto, por razões ainda desconhecidas, a interação carrapato vetor- $R$. rickettsii-hospedeiro amplificador não resulta, na maioria das regiões endêmicas, em altas taxas de prevalência do patógeno nas populações de carrapatos vetores. Nessas regiões, como mencionado anteriormente, a prevalência de carrapatos infectados é muito baixa, podendo chegar à zero em alguns períodos analisados 
(Burgdorfer, 1988; Fritzen et al., 2011; Guedes et al., 2005; McDade, NewHouse, 1986; Pinter \& Labruna, 2006; Sangioni et al., 2005). É provável que o desaparecimento da bactéria da população de carrapatos em determinados períodos seja decorrente de dois fenômenos, (i) ausência de animais sentinelas (equinos e cães) soro-reativos para a bactéria (Cardoso et al., 2006); além do (ii) aumento da virulência da bactéria para o vetor (Burgdorfer, 1988; Niebylski et al., 1999), muito embora os mecanismos para tal fenômeno sejam ainda desconhecidos.

\subsection{Estudos moleculares da interação entre carrapatos e patógenos por eles transmitidos}

\subsubsection{Expressão gênica de carrapatos infectados}

$R$. rickettsii, como descrito anteriormente, é uma bactéria intracelular obrigatória. A patogenicidade de $R$. rickettsii para o hospedeiro vertebrado já está bem caracterizada desde a década de 80 (Walker, 1989). Entretanto, no caso dos hospedeiros invertebrados, especificamente carrapatos $A$. aureolatum e $A$. cajennense, os poucos trabalhos existentes descrevem apenas as consequências danosas desta infecção sobre os parâmetros biológicos de alimentação de fêmeas adultas, oviposição e porcentagem de eclosão dos ovos (Labruna et al., 2011; Soares et al., 2012).

Dentre os poucos trabalhos da literatura que relatam os efeitos da infecção por bactérias do gênero Rickettsia sobre os seus carrapatos vetores ao nível molecular, todos foram realizados utilizando-se $R$. montanensis (Ceraul et al., 2007; Macaluso et al., 2003; Macaluso et al., 2006; Mulenga et al., 2003; Sunyakumthorn et al., 2012). Dentre esses trabalhos, Macaluso e colaboradores (2003) compararam a expressão gênica global de carrapatos $D$. variabilis não infectados com a expressão de uma linhagem cronicamente infectada por $R$. montanensis. Através da metodologia de PCR differential-display, o trabalho relata que a infecção deflagrou a indução da expressão de diversos genes nos ovários de fêmeas de $D$. variabilis, como genes codificadores de ATPase, a-tubulina, proteína rica em glicina e $\alpha$ catenina. Dentre essas proteínas, a $\alpha$-catenina foi caracterizada funcionalmente por Sunyakumthorn e colaboradores (2012) no carrapato $D$. variabilis como atuante na organização do citoesqueleto de actina, processo fundamental para a invasão da 
célula hospedeira por microrganismos como riquétsias. Diferentemente do que foi demonstrado por Macaluso e colaboradores (2003), esse trabalho mostrou que ocorre uma modulação negativa dessa molécula em ovários infectados por $R$. montanensis, indicando uma possível tentativa do vetor de impedir a utilização de componentes do seu citoesqueleto para a invasão bacteriana. As reações do carrapato para tentar controlar a invasão bacteriana também foram analisadas por Ceraul e colaboradores (2007). Este estudo avaliou o perfil de expressão de genes codificadores de peptídeos antimicrobianos (duas defensinas e uma lisozima) em carrapatos $D$. variabilis ao longo de uma infecção por $R$. montanensis. Os dados mostraram que a expressão dos genes codificadores dos peptídeos antimicrobianos foi induzida tanto no intestino quanto no corpo gorduroso dos carrapatos e que o tempo necessário para que essa indução seja deflagrada após a infecção parece depender tanto do tecido quanto do gene analisado.

Embora os trabalhos acima mencionados tenham contribuído para um melhor entendimento da interação Rickettsia-carrapato vetor, eles não podem ser extrapolados para uma infecção por $R$. rickettsii, já que $R$. montanensis parece não ser patogênica para os carrapatos, tampouco para humanos e animais domésticos (Ceraul et al., 2007). Assim, a caracterização molecular das interações entre $R$. rickettsii e $A$. aureolatum faz-se fundamental para uma melhor compreensão da FMB.

Diversos estudos envolvendo análises do perfil de expressão gênica de carrapatos infectados por vários outros patógenos também foram previamente reportados: D. variabilis infectados pelas bactérias Borrelia burgdorferi (Johns et al., 2000) e Anaplasma marginale (de la Fuente et al., 2007), Rhipicephalus appendiculatus infectados pelo protozoário Theileria parva (Nene et al., 2004), Ixodes ricinus infectados por B. burgdorferi (Rudenko et al., 2005); Ixodes scapularis frente ao desafio com $A$. marginale e A. phagocytophilum (Zivkovic et al., 2009); Rhipecephalus (Boophilus) microplus infectados por A. marginale (Zivkovic et al., 2010); Amblyomma americanum infectados pela bactéria Erlichia chaffeensis (Karim et al., 2012) e I. scapularis infectados pelo vírus Langat (flavivírus) (McNally et al., 2012). De uma maneira geral, os resultados destes trabalhos demonstraram que a infecção apresenta um efeito modulador sobre a expressão de genes codificadores de proteínas relacionadas com estresse, defesa do carrapato ou para o estabelecimento da infecção. 
1.5.2 Reativação da virulência de riquétsias durante a infecção do carrapato-vetor e expressão gênica frente a diferentes condições ambientais

A reativação da virulência de vírus, bactérias e protozoários é um fenômeno comum (Barragan et al., 2008; Gilford, Price, 1955; Reynolds et al., 2008; Spencer, Parker, 1923;) e previamente descrito em $R$. rickettsii infectando carrapatos (Gilford, Price, 1955; Spencer, Parker, 1923). Nesses dois últimos trabalhos, Spencer e Parker (1923) e Gilford e Price (1955) relataram que $R$. rickettsii encontra-se em um estado avirulento em carrapatos em jejum ou mantidos a temperaturas próximas à ambiental, uma vez que a inoculação de homogeneizados de carrapatos nessas condições em cobaias não deflagrou a sintomatologia da infecção. A sintomatologia só foi observada quando carrapatos infectados foram previamente alimentados em um hospedeiro (Gilford, Price, 1955) ou mantidos em temperaturas elevadas $\left(35^{\circ} \mathrm{C}\right.$ a $37^{\circ} \mathrm{C}$ ) (Spencer, Parker, 1923) por 24 a 48 horas e, então homogeneizadas e inoculadas nos animais. Alguns anos mais tarde, Hayes e Burgdorfer (1982) realizaram um estudo de ultraestrutura de $R$. rickettsii em carrapatos, observando diferenças marcantes na membrana das bactérias de carrapatos em jejum em relação às bactérias de carrapatos alimentados. Tais diferenças também foram associadas ao fenômeno de reativação da virulência da bactéria. Além disso, Policastro e colaboradores (1997) demonstraram que a temperatura influencia a expressão proteica de $R$. rickettsii mantida em uma cultura de células in vitro. Os autores observaram que proteínas diferentes são expressas pelas bactérias infectando culturas de células mantidas a $28^{\circ} \mathrm{C}$ e a $34^{\circ} \mathrm{C}$, sugerindo que este perfil diferencial também ocorra quando as bactérias estão infectando seu carrapato vetor (temperaturas próximas a $28^{\circ} \mathrm{C}$ ) ou hospedeiros mamíferos (temperaturas próximas a $\left.34^{\circ} \mathrm{C}\right)$.

Embora tenham sugerido que a alimentação sanguínea e a temperatura sejam fatores importantes para a reativação da virulência de $R$. rickettsii em carrapatos, os mecanismos moleculares desta reativação não foram elucidados. Dessa maneira, a determinação da expressão gênica de Rickettsia em carrapatos não alimentados e alimentados, bem como de bactérias infectando carrapatos mantidos em diferentes temperaturas, pode gerar dados que permitam inferir se o fenômeno de reativação de $R$. rickettsii é ocasionado por um aumento da temperatura ou se depende de fatores presentes na alimentação sanguínea. 
Com o avanço dos estudos genômicos e o desenvolvimento de tecnologias, a análise do perfil de expressão de genes (transcriptoma) de um organismo, tecido ou conjunto de células, nos fornece, atualmente, novas formas de investigar a interação entre patógenos e as células do hospedeiro. Essa é uma importante abordagem para se compreender os mecanismos envolvidos nos mais diversos processos celulares. De fato, a determinação da expressão gênica de um patógeno durante a infecção do vetor ou do hospedeiro pode fornecer informações importantes para o melhor entendimento da relação patógeno-hospedeiro e, dessa forma, vem sendo empregada para o estudo de uma grande diversidade de agentes etiológicos (La et al., 2007).

Uma das tecnologias de análises de transcrição gênica em larga escala disponíveis é o microarranjo. Essa técnica permite a análise quantitativa dos níveis de expressão de milhares de genes simultaneamente (Conway, Schoolnik, 2003; Hughes, Shoemaker, 2001; Leroy, Raoult, 2010; Schulze, Downward, 2001). Além disso, são potentes ferramentas para a utilização da grande quantidade de informações geradas a cada dia pelos projetos de sequenciamento de genomas, auxiliando a caracterização funcional de genes codificadores de proteínas hipotéticas (Pashalidis et al., 2005; Zaini et al., 2008). A metodologia de microarranjos vem sendo amplamente utilizada para a detecção de alterações na expressão gênica de bactérias, uma vez que a regulação ao nível da transcrição desempenha um papel fundamental em procariotos (Ehrenreich, 2006; Lucchini et al., 2001; Ng et al., 2003; Schoolnik, 2002). Dentre os diferentes tipos de microarranjos, aqueles baseados em oligonucleotídeos são os mais utilizados atualmente por apresentarem uma maior especificidade em comparação aos microarranjos baseados em amplicons. Além disso, asseguram uma melhor uniformidade na concentração das sondas e afinidade na hibridização, diminuindo assim, a chance de ocorrerem hibridizações cruzadas (Kreil et al., 2006).

Com a elucidação completa do genoma de várias espécies do gênero Rickettsia, hoje é possível utilizar o microarranjo para a análise de expressão gênica em larga escala dessas bactérias. Ellison e colaboradores (2008), por exemplo, realizaram um estudo comparativo da expressão de genes de uma cepa virulenta de $R$. rickettsii (denominada cepa R) com uma cepa avirulenta (lowa). Essa metodologia também foi utilizada para a determinação dos efeitos da restrição de nutrientes sobre o perfil de expressão gênica de $R$. conorii (La et al., 2007) e de $R$. rickettsii (Ellison et al., 
2009) e dos efeitos da temperatura sobre $R$. typhi (Dreher-Lesnik et al., 2008), $R$. prowazekii (Audia et al., 2008) e $R$. rickettsii (Ellison et al., 2009).

A influência da temperatura tem sido um dos principais agentes ambientais utilizados nos estudos das alterações dos perfis de expressão gênica de bactérias intracelulares em infecções in vitro (revisão de Leroy, Raoult, 2010). Essas alterações nos níveis transcricionais de genes auxiliam os microrganismos a se adaptar a um novo ambiente, podendo, consequentemente, garantir sua sobrevivência, perpetuando a espécie. Por exemplo, foi demonstrado que a temperatura modula a expressão gênica de $R$. typhi, o agente etiológico do tifo murino, o qual é transmitido por pulgas (Dreher-Lesnik et al., 2008). Interessantemente, os autores observaram que genes codificadores de proteínas de choque térmico e de proteínas envolvidas com o metabolismo bacteriano são reprimidos pela diminuição da temperatura de $37{ }^{\circ} \mathrm{C}$ para $25^{\circ} \mathrm{C}$, as quais mimetizam, respectivamente, as temperaturas do hospedeiro vertebrado e do insetovetor. O efeito da temperatura sobre o perfil de expressão de genes spoT de $R$. conorii, agente etiológico da febre maculosa do Mediterrâneo, foi avaliado por Rovery e colaboradores (2005). Esses genes apresentam múltiplas cópias e estão associados à adaptação gênica da bactéria a estresses. Nesse trabalho, foi demonstrado que a expressão de spoT1 é induzida pela elevação da temperatura de $10{ }^{\circ} \mathrm{C}$ para $37^{\circ} \mathrm{C}$. Audia e colaboradores (2008), em uma análise de transcrição gênica global de $R$. prowazekii, causadora do tifo epidêmico, exposta ao aumento de temperatura de $34^{\circ} \mathrm{C}$ para $42{ }^{\circ} \mathrm{C}$, demonstraram que $57 \%$ dos genes induzidos são homólogos a genes conhecidamente associados a estresses de temperatura. Em $R$. rickettsii, Ellison e colaboradores (2009) observaram que a expressão gênica de bactérias infectando uma linhagem celular de carrapatos $I$. scapularis (ISE6) mantidas a $37{ }^{\circ} \mathrm{C}$ ou a $22{ }^{\circ} \mathrm{C}$ não apresenta diferenças expressivas (utilizando fold change cut-off $>3,0$ ). $O$ mesmo foi observado para bactérias cultivadas em células Vero mantidas a $34{ }^{\circ} \mathrm{C}$ ou a $25{ }^{\circ} \mathrm{C}$. A modulação da expressão gênica só foi detectada quando $R$. rickettsii foi cultivada a $34{ }^{\circ} \mathrm{C}$ por 3 dias e, em seguida, exposta a uma temperatura de $4^{\circ} \mathrm{C}$ por 2 horas (28 genes modulados) ou por 24 horas (56 genes modulados). Interessantemente, os autores observaram que o decréscimo da temperatura de $34{ }^{\circ} \mathrm{C}$ para $4{ }^{\circ} \mathrm{C}$ reprimiu a expressão de três genes ligados ao enovelamento de novas proteínas sintetizadas, o que justificaria o retardo no crescimento da bactéria a baixas temperaturas. A modulação do perfil de expressão 
gênica por variações de temperatura também já foi relatada para outros gêneros de bactérias que acometem o homem, tais como Mycobacterium tuberculosis (Stewart et al., 2002), Borrelia burgdorferi (Ojaimi et al., 2003; Stevenson et al., 2006; Tokarz et al., 2004), Yersinia pestis (Han et al., 2004) e Listeria monocytogenes (van der Veen et al., 2007).

Além da temperatura, a carência nutricional já foi descrita como um importante fator de modulação da expressão gênica principalmente de microrganismos intracelulares obrigatórios, os quais são dependentes de nutrientes da célula alvo (Ellison et al., 2009; La et al., 2007; Wike, Burgdorfer; 1972; Winkler, 1990). Especificamente no caso de microrganismos que infectam células de invertebrados que se alimentam de sangue, a ausência ou presença da alimentação sanguínea integral ou parcial desfavoreceu o crescimento e alterou a expressão gênica bacteriana (Ellison et al., 2009; La et al., 2007; Rovery et al., 2005; Spencer, Parker, 1923; Wike, Burgdorfer; 1972;). Ao nível molecular, Rovery e colaboradores (2005) analisaram, além da influência da temperatura, a modulação dos cinco genes spoT de $R$. conorii sob um estresse nutricional. Apenas o gene spoT1 teve transcrição induzida quando o carrapato foi privado de alimentação ou quando células Vero infectadas foram privadas do meio de cultura rico em nutrientes. Assim, os autores associaram a modulação específica de spoT1 como um sinal para a limitação do crescimento sob carência nuctricional. A modulação dos genes spoT frente à ausência de nutrientes também foi demonstrada anteriormente em $B$. burgdorferi (Concepcion et al., 1999; Fraser et al., 1997). Ainda em R. conorri, foi descrito que a carência nutricional induz a transcrição de genes de virulência, tais como um antígeno de superfície (sca4) e quatro componentes do sistema de secreção do tipo IV (virB4, virB9 virB10 e virB11) (La et al., 2007). A fim de avaliar a influência de componentes sanguíneos na expressão gênica global de $R$. rickettsii in vitro, Ellison e colaboradores (2009) adicionaram um agente quelante de ferro ao cultivo de células Vero e ISE6. Foi detectada uma alteração no crescimento bacteriano e a modulação de cinco genes nesta condição (fold-change cut-off > 3,0). Neste caso, todos os genes modulados codificam proteínas hipotéticas e por isso não se conseguiu discutir a relação funcional da variável biológica na expressão deles.

Apesar de terem gerado informações importantes para o conhecimento da interação de riquétsias com seus vetores e/ou hospedeiros, todos os trabalhos acima mencionados foram realizados in vitro. Dessa maneira, o estudo da expressão 
gênica de $R$. rickettsii infectando seus vetores naturais torna-se necessário, podendo fornecer informações importantes para o melhor entendimento da relação patógenohospedeiro, podendo ainda revelar potenciais alvos para o desenvolvimento de vacinas para o controle da RMSF.

Pouco também é conhecido acerca dos efeitos de estímulos ambientais sobre os perfis de expressão gênica de microrganismos, principalmente de bactérias intracelulares obrigatórias, em tecidos específicos dos seus vetores ou hospedeiros. A expressão diferenciada destes organismos em diferentes tecidos podem indicar as adaptações pelas quais os organismos precisam estabelecer baseados no tipo celular em que estão associados. Dentre os poucos trabalhos da literatura, existem relatos da adaptação da espiroqueta $B$. burgdorferi aos tecidos de seus hospedeiros vertebrados mamíferos e também aos seus carrapatos vetores (Narasimhan et al., 2002; Piesman et al., 2003; revisão de Stevenson et al., 2006). Essa adaptação tem como objetivo manter, com sucesso, o seu ciclo de infecção. Durante este ciclo, a bactéria enfrenta diferentes ambientes, usufrui de diversos nutrientes das células hospedeiras e, por fim, consegue evadir do sistema imune de seus hospedeiros. Para isso, a bactéria tem respostas transcricionais diferentes dependendo do desafio que ela encontra em cada ambiente que coloniza (Stevenson et al., 2006). Como mostrado por Piesman e colaboradores (2003), utilizando amostras do carrapato $I$. scapularis alimentados, a expressão gênica de diversas proteínas de membrana foram diferentemente moduladas, dependendo do tecido do carrapato que infectavam. O nível transcricional das proteínas imunomoduladoras de superfícies OspC e OspA foram analisadas. Enquanto a transcrição de $0 s p C$ foi induzida no intestino e nas glândulas salivares do carrapato, ospA não foi modulada em intestinos e foi reprimida em glândulas salivares. Baseados nestes resultados, os autores especulam que a expressão diferencial tecidual pode estar relacionada à importância destes genes na dinâmica de infecção no invertebrado e na transmissão da bactéria para o hospedeiro vertebrado. No caso de $R$. rickettsii, ainda não existe nenhum estudo descritivo do efeito molecular tecido-específico da infecção, tanto em células de vertebrados como de invertebrados.

Deste modo, estudos dos efeitos de fatores ambientais sobre a transcrição de $R$. rickettsii em tecidos específicos do vetor também são importantes, podendo gerar subsídios para se estabelecerem, no futuro, estratégias mais eficientes de controle da FMB. 


\section{OBJETIVO}

Com base nos dados da literatura acima apresentados, o objetivo geral deste trabalho foi de avaliar os efeitos da temperatura e da alimentação sanguínea sobre o perfil de expressão gênica de Rickettsia rickettsii durante a infecção do carrapato vetor Amblyomma aureolatum.

Como objetivos específicos, propusemos:

1. Determinar os efeitos da elevação da temperatura sobre o perfil de expressão gênica de $R$. rickettsii em carrapatos $A$. aureolatum adultos pela metodologia de microarranjos de oligonucleotídeos;

2. Determinar os efeitos da alimentação sanguínea sobre o perfil de expressão gênica de $R$. rickettsii em carrapatos $A$. aureolatum adultos por microarranjos de oligonucleotídeos;

3. Validar os dados obtidos pelos microarranjos através de RT-qPCR;

4. Analisar a expressão de alguns dos genes validados no intestino e nas glândulas salivares de carrapatos machos e fêmeas por RT-qPCR microfluídica. 


\section{MATERIAL E MÉTODOS}

\subsection{Rickettsia rickettsii}

A cepa de Rickettsia rickettsii utilizada neste estudo, denominada Taiaçu, foi originalmente isolada de um espécime do carrapato $A$. aureolatum proveniente do município de Mogi das Cruzes - SP. O homogeneizado deste espécime foi inoculado em cobaias para a amplificação das bactérias. As cobaias foram sacrificadas no pico febril da infecção por $R$. rickettsii e seus órgãos foram dissecados, homogeneizados e armazenados a $-80{ }^{\circ} \mathrm{C}$. Este homogeneizado de órgãos foi utilizado para a inoculação de novas cobaias ou para a manutenção das bactérias em uma cultura in vitro de células Vero (Pinter, Labruna, 2006).

\subsection{Células embrionárias do carrapato Rhipicephalus (Boophilus) microplus (BME26)}

A linhagem de células embrionárias de carrapatos Rhipicephalus (Boophilus) microplus utilizada neste estudo, denominada de linhagem BME26, foi gentilmente cedida pela Profa. Dra. Sirlei Daffre, ICB-USP. A linhagem foi isolada por Holman e Ronald (1980) e caracterizada por Esteves e colaboradores (2008). Para uso em nossos experimentos, as células foram cultivadas em $5 \mathrm{~mL}$ de meio de cultura L15B300 (Munderloh et al., 1999) suplementado com $5 \%$ de soro fetal bovino termoinativado (Life Technologies, EUA), 10\% de meio triptose fosfato (BD Difco, EUA), $0,1 \%$ de um concentrado de lipoproteínas bovinas (Life Technologies), $100 \mathrm{U} / \mathrm{mL}$ de penicilina e $100 \mathrm{U} / \mathrm{mL}$ de estreptomicina (Life Technologies), sendo o $\mathrm{pH}$ acertado para 7,2, conforme descrito por (Esteves et al., 2008). As células foram mantidas a $34{ }^{\circ} \mathrm{C}$ em incubadora BOD e subcultivadas a cada 20 dias de modo a manterem-se as condições ideais para o seu crescimento.

\subsection{Carrapatos}

Os carrapatos utilizados neste estudo foram provenientes da colônia de Amblyomma aureolatum de Atibaia, São Paulo, mantida no laboratório do Prof. Dr. Marcelo Bahia Labruna (FMVZ-USP, São Paulo, SP). Durante as fases de vida 
parasitária, os carrapatos foram alimentados em cobaias (Cavia porcellus; estádio larval), em coelhos (Oryctolagus cuniculus; estádio de ninfa) e em cães (Canis familiares; estádio adulto). Nas fases de vida livre, os carrapatos foram mantidos em incubadora BOD com temperatura ajustada para $25^{\circ} \mathrm{C}$ e umidade relativa (UR) de $95 \%$.

\subsection{Infecção experimental de células BME26 por R. rickettsii}

Células BME26 foram cultivadas conforme descrito no item 3.2 até a monocamada atingir cerca de $3,00 \times 10^{6}$ células. Três dias antes da infecção, o meio de cultura foi substituído por meio sem antibiótico e $0 \mathrm{pH}$ foi mantido a 7,2 (ideal para as células BME26) ou elevado para 7,4 (ideal para as riquétsias). Paralelamente, um inóculo criopreservado de $R$. rickettsii em células Vero, cedido pelo Prof. Dr. Marcelo B. Labruna (FMVZ-USP), foi descongelado em banho-maria a $37{ }^{\circ} \mathrm{C}$ por $3 \mathrm{~min}$. Em seguida, diferentes diluições $(1: 1,1: 10$, 1:100 ou 1:1000, volume/volume) do inóculo foram adicionadas à monocamada de células BME26. Após a inoculação, as garrafas contendo as células foram transferidas para uma BOD a $28^{\circ} \mathrm{C}$ ou permaneceram a $34^{\circ} \mathrm{C}$. Logo após a adição do inóculo (tempo $0 \mathrm{~h}$ ) e após 24,48 , e 72 h do início da infecção, as células de uma garrafa de cada condição analisada foram descoladas pelo uso de um dispositivo Cell Scraper (Thermo Fisher Scienfic, EUA). Alíquotas de $1 \mathrm{~mL}$ foram utilizadas para a determinação do número de células viáveis e para a visualização das células por microscopia ótica. Alíquotas de $1 \mathrm{~mL}$ da suspensão celular também foram centrifugadas a $3.000 x g$ por 5 min a $4{ }^{\circ} \mathrm{C}$, sendo o precipitado celular ressuspendido em $100 \mu \mathrm{L}$ de RNAlater (Life Technologies) e mantido a $-20{ }^{\circ} \mathrm{C}$ até a extração de ácidos nucleicos (item 3.7). O DNA genômico resultante da extração foi utilizado para a quantificação do número de riquétsias por reação em cadeia da polimerase quantitativa (qPCR) conforme detalhado no item 3.8.

O número de células viáveis por $\mathrm{mL}$ foi determinado por contagem em uma câmara de Neubauer após a coloração com uma solução de azul de Tripan a 4\%. Para a visualização das células, $100 \mu \mathrm{L}$ da suspensão foram centrifugados por 5 min contra uma lâmina de vidro, utilizando-se uma citocentrífuga (Fanem, Brasil). As células aderidas às lâminas foram coradas pela utilização de dois métodos diferentes: Gimenez (Garduño et al., 2002) ou Panótico (Instant Prove, Brasil). Na 
coloração por Gimenez, as lâminas foram submersas por 2 min em uma solução de fucsina básica $10 \%$ e fenol aquoso 4\%, enxaguadas com água destilada e submersas, em seguida, em uma solução de verde malaquita 0,8\% por duas vezes, com duração de $10 \mathrm{~s}$ cada. Para a coloração por Panóptico, seguiu-se o protocolo do fabricante. Após a coloração, as células foram observadas sob microscópio Zeiss-Axiofhot (Zeiss, Alemanha), utilizando-se um aumento de 1000x.

A fim de obter-se um inóculo de $R$. rickettsii em células BME26, os procedimentos acima descritos foram repetidos. Para tal, o inóculo em células Vero (diluição 1:100) foi adicionado a uma monocamada de células em pH 7,2. Após 48h a $34{ }^{\circ} \mathrm{C}$, uma alíquota da suspensão foi removida para a extração de DNA genômico e quantificação do número de riquétsias por qPCR. O restante da suspensão celular foi centrifugado a $3.000 \mathrm{xg}$ por 10 min e o precipitado foi ressuspendido em meio de cultura L-15B300 suplementado (descrito no item 3.2) sem antibiótico e $10 \%$ de dimetil sulfóxido (DMSO), próprio para o congelamento. Essa suspensão foi dividida em alíquotas de $1 \mathrm{~mL}$ e armazenada em um container de congelamento programável (Sigma-Aldrich, EUA), seguindo-se o procedimento descrito pelo fabricante. Após congelamento, as alíquotas foram transferidas e armazenadas em nitrogênio líquido até a sua utilização nos experimentos.

3.4.1 Determinação da curva de crescimento de Rickettsia rickettsii em células embrionárias de carrapatos

Monocamadas com cerca de 3,00 × $10^{6}$ células BME26 em pH 7,2 receberam um inóculo de $9,02 \times 10^{6}$ riquétsias (obtido conforme descrito no item 3.4) [MOI (multiplicity of infection) de 3,0]. Após a inoculação, as garrafas contendo as células foram transferidas para uma BOD a $34^{\circ} \mathrm{C}$. Logo após a adição do inóculo (tempo 0 h) e em intervalos de $12 \mathrm{~h}$ (até $60 \mathrm{~h}$ ), as monocamadas celulares de três garrafas (triplicatas biológicas) foram descoladas pelo uso de um dispositivo Cell Scraper (Thermo Fisher Scientific). As células provenientes de cada garrafa foram utilizadas para a contagem do número de células BME26 viáveis por $\mathrm{mL}$ (item 3.4) e para a quantificação absoluta do número de $R$. rickettsii por qPCR quantitativo (item 3.8). 


\subsection{Infecção experimental de $A$. aureolatum por $\boldsymbol{R}$. rickettsii}

Primeiramente, os soros de três cobaias foram avaliados através da reação de imunofluorescência indireta (RIFI) com antígeno de $R$. rickettsii para atestar que as mesmas não haviam tido contato prévio com esse patógeno (Labruna et al., 2008). Câmaras de tecido de algodão foram afixadas ao dorso previamente tricotomizado de cada animal para a alimentação dos carrapatos, as quais restringem a área de fixação, impedindo a fuga e permitindo um maior controle do processo parasitário. Após $24 \mathrm{~h}$, as cobaias foram inoculadas intraperitonealmente com um homogeneizado de fígado e de baço de uma cobaia previamente sacrificada durante o pico febril da infecção por $R$. rickettsii. Em seguida, as larvas foram depositadas nas câmaras de infestação.

As câmaras foram abertas três vezes ao dia durante um período de 8 a 12 dias para o recolhimento das larvas ingurgitadas, desprendidas naturalmente dos hospedeiros. As larvas foram transferidas para incubadoras BOD para realizar a ecdise para o estádio de ninfa, processo que leva em torno de 20 dias. Após 20 dias adicionais ao término da ecdise para o estádio de ninfa, as mesmas foram alimentadas em coelhos, também através da utilização de câmaras de infestação. As ninfas ingurgitadas foram recolhidas das câmaras e transferidas para incubadoras BOD para a ecdise para o estádio adulto.

Após aproximadamente 60 dias, os carrapatos $A$. aureolatum adultos foram subdivididos em três grupos experimentais. Dois grupos não foram alimentados, tendo sido mantidos em incubadora BOD a $25^{\circ} \mathrm{C}$ (grupo 1 - G1) ou a $35^{\circ} \mathrm{C}$ (grupo 2 - G2). O outro grupo (grupo 3 - G3) foi alimentado em cães. Após 3 dias de incubação ou de alimentação, os carrapatos foram lavados em PBS (tampão salino fosfato; $\mathrm{NaCl}$ 0,14 M; KCl 2,7 mM; $\mathrm{Na}_{2} \mathrm{HPO}_{4} 10$ mM; $\mathrm{KH}_{2} \mathrm{PO}_{4}$ 1,8 mM; pH 7,4) estéril e dissecados (item 3.6). Os cães utilizados para a infestação com carrapatos adultos foram monitorados para a infecção por $R$. rickettsii, conforme descrito anteriormente para as cobaias e coelhos.

Todos os animais utilizados para a alimentação dos carrapatos foram monitorados clinicamente para a infecção por $R$. rickettsii durante todo o período de alimentação das ninfas. Além disso, a avaliação sorológica foi realizada nos animais sobreviventes 21 dias após a infestação com carrapatos infectados para a averiguação de soro-conversão, conforme descrito por (Labruna et al., 2007). Os 
procedimentos para a experimentação com os animais foram aprovados pelos Comitês de Ética em Experimentação Animal da Faculdade de Medicina Veterinária e Zootecnia e do Instituto de Ciências Biomédicas da Universidade de São Paulo.

\subsection{Dissecção das glândulas salivares e intestinos de $A$. aureolatum infectados por $R$. rickettsii}

Cada exemplar de carrapato foi transferido para uma base de parafina de cor contrastante (vermelha) com a região dorsal voltada para cima. Quatro incisões na cutícula, nas regiões anterior, posterior e nas duas laterais, foram cuidadosamente realizadas sob lupa estereoscópica binocular (modelo TL-2, Olympus, Japão) com o auxílio de uma lâmina de bisturi. As incisões permitiram que a cutícula dorsal fosse completamente rebatida com o auxílio de uma pinça.

Em seguida, todos os órgãos ou as glândulas salivares e o intestino foram dissecados, lavados em PBS estéril e transferidos para tubos de polipropileno contendo $100 \mu \mathrm{L}$ de RNAlater (Life Technologies) para os órgãos e $50 \mu \mathrm{L}$ para cada intestino ou par de glândulas salivares. Os órgãos foram armazenados a $-20^{\circ} \mathrm{C}$ até a utilização para a extração de ácidos nucléicos (item 3.7).

\subsection{Isolamento de DNA genômico e RNA total}

As células BME26 e os órgãos armazenados a $-20{ }^{\circ} \mathrm{C}$ em RNAlater (Life Technologies) foram homogeneizados no mesmo reagente com o auxílio de um homogeneizador Potter-Elvehjen. Os homogeneizados foram individualmente submetidos ao isolamento simultâneo de DNA e de RNA pela utilização do Invisorb TwinSpin Cell Mini kit (Invitek, Alemanha), de acordo com as especificações do fabricante. Ao final do procedimento, as concentrações de DNA e de RNA de cada amostra foram determinadas em um espectrofotômetro (modelo NanoDrop-1000, Thermo Fisher Scientific). O RNA total foi submetido a uma eletroforese em gel de agarose a 1,5\% e, após a coloração com brometo de etídeo, a integridade do RNA foi aferida pela visualização em um transiluminador acoplado a um sistema de imagens (modelo ImageQuant ${ }^{\mathrm{TM}}$ 300, GE Healthcare, Reino Unido). Para monitoramento da infecção durante as infestações de $A$. aureolatum, os ácidos nucléicos de alguns exemplares de ninfas infectadas e não-infectadas (controle) 
também foram extraídos pela mesma metodologia acima descrita. Todas as amostras de DNA e de RNA foram armazenadas a $-20{ }^{\circ} \mathrm{C}$ e a $-80{ }^{\circ} \mathrm{C}$, respectivamente, até a sua utilização nos experimentos.

\subsection{Quantificação da infecção por R. rickettsii}

3.8.1 Clonagem de um fragmento de $147 \mathrm{pb}$ do gene da citrato sintase (gltA) de Rickettsia spp.

Cinquenta ng do DNA genômico de dois exemplares de carrapatos $A$. aureolatum infectados por $R$. rickettsii foram utilizados como molde para a amplificação de um fragmento de 147 pb do gene da citrato sintase ( $g / t A)$ dessa bactéria. A reação foi realizada utilizando-se 10 pmol dos oligonucleotídeos CS-5 (5'-GAG AGA AAA TTA TAT CCA AAT GTT GAT-3') e CS-6 (5'- AGG GTC TTC GTG CAT TTC TT-3'), 0,5 mM de uma mistura de desoxorribonucleotídeos trifosfosfatados (dNTP), 2,5 mM de cloreto de magnésio $\left(\mathrm{MgCl}_{2}\right)$, tampão para Taq DNA polimerase diluído para 1x (volume/volume) e 1U de Taq DNA polimerase (Biotools, Espanha), sendo o volume de $20 \mu \mathrm{L}$ completado com $\mathrm{H}_{2} \mathrm{O}$ ultrapura estéril. O programa térmico utilizado foi de 2 min a $95{ }^{\circ} \mathrm{C}$ seguidos de 35 ciclos de 30 s a 95 ${ }^{\circ} \mathrm{C}$, 30s a $55^{\circ} \mathrm{C}$ e $1 \mathrm{~min}$ a $72{ }^{\circ} \mathrm{C}$, o qual foi realizado por um termociclador Mastercycler® Gradient (Eppendorf, Alemanha). Os produtos da PCR foram analisados por eletroforese em gel de agarose a $2 \%$. Após a coloração do DNA com brometo de etídeo, o mesmo foi visualizado pelo auxílio de um transiluminador acoplado a um sistema de imagens (modelo ImageQuant ${ }^{\mathrm{TM}}$ 300, GE Healthcare). A banda referente ao fragmento de $147 \mathrm{pb}$ foi recortada do gel e o DNA nela contido foi purificado pela utilização do Wizard® SV Gel and PCR Clean-Up System (Promega, EUA), conforme as instruções do fabricante.

O DNA isolado foi submetido a uma reação de ligação com o pGEM ${ }^{\circledR}$ T Easy Vector (Promega), de acordo com o procedimento recomendado pelo fabricante. $O$ produto de ligação foi incubado com uma suspensão de Escherichia coli DH5-a por $30 \mathrm{~min}$ em banho de gelo, seguidos de $1 \mathrm{~min}$ e $30 \mathrm{~s}$ a $42{ }^{\circ} \mathrm{C}$ e $3 \mathrm{~min}$ adicionais em banho de gelo. Após a adição de $400 \mu \mathrm{L}$ de meio Lúria-Bertani (LB), a suspensão foi incubada por $30 \mathrm{~min}$ a $37{ }^{\circ} \mathrm{C}$ sob agitação de $300 \mathrm{rpm}$ e, em seguida, semeada em meio LB agar 1,5\% contendo IPTG (concentração final de 0,5 mM), X-Gal 
(concentração final de $320 \mu \mathrm{g} / \mathrm{L}$ ) e ampicilina (concentração final de $50 \mu \mathrm{g} / \mathrm{L}$ ). Após $18 \mathrm{~h}$ de incubação a $37^{\circ} \mathrm{C}$, três unidades formadoras de colônia (UFC) de coloração branca foram semeadas em $3 \mathrm{~mL}$ de meio LB contendo ampicilina (concentração final de $50 \mu \mathrm{g} / \mathrm{L})$. Após $18 \mathrm{~h}$ de cultivo a $37^{\circ} \mathrm{C}$ sob agitação de $1.000 \mathrm{rpm}, 1,5 \mathrm{~mL}$ da suspensão bacteriana foram submetidos a uma centrifugação a 4.000 x g por 10 min a $4^{\circ} \mathrm{C}$. O DNA plasmidial do sedimento resultante foi extraído pela utilização do Wizard® Plus SV MiniPreps DNA Purification System (Promega). Após a quantificação, $100 \mathrm{ng}$ do DNA plasmidial foram submetidos ao sequenciamento de nucleotídeos utilizando-se o ABI Prism® dGTP Big Dye Terminator Reaction kit with AmpliTaq® DNA Polimerase (Life Technologies) e 3,2 pmol dos oligonucleotídeos M13 senso (5'GTAAAACGACGGCCAG3') ou M13 antissenso (5'CAGGAAACAGCTATGAC3'). O sequenciamento automático das duas fitas complementares dos três clones foi realizado em um equipamento ABI Prism 310 (Life Technologies). As sequências resultantes foram analisadas pelo programa BioEdit, versão 7.0.9 (Tom Hall, Ibis Biosciences, EUA). Após a confirmação da identidade da sequência obtida com o fragmento de $147 \mathrm{pb}$ da citrato sintase de $R$. rickettsii, diluições do DNA plasmidial foram preparadas para a construção de uma curva-padrão para a quantificação absoluta do número de $R$. rickettsii por PCR quantitativa. O gene gltA é um gene de cópia única, permitindo que o número de riquétsias seja quantificado com base no número de cópias do gene identificado em uma amostra.

\subsubsection{PCR quantitativa}

Para cada reação, 8 pmol de cada um dos oligonucleotídeos CS-5 e CS-6 e 0,5 pmol da sonda interna fluorogênica (5' - 56 FAM - CAT TGT GCC ATC CAG CCT ACG GT - BHQ 1 - 3') foram adicionados a 50 ng de cada amostra de DNA genômico ou a diluições seriadas na base 10 do DNA plasmidial contendo 0 fragmento do gene gltA $\left(5,30 \times 10^{7}\right.$ a $5,30 \times 10^{2}$ cópias $)$. As reações foram realizadas pela utilização do QuantiMix Easy Probes kit (Biotools), de acordo com o procedimento descrito pelo fabricante. O programa térmico utilizado foi de 2 min a 95 ${ }^{\circ} \mathrm{C}$ seguidos de 50 ciclos de $15 \mathrm{~s}$ a $95{ }^{\circ} \mathrm{C}$, $15 \mathrm{~s}$ a $55^{\circ} \mathrm{C}$ e 20 s a $68^{\circ} \mathrm{C}$, o qual foi realizado por um termociclador para PCR quantitativas (qPCR), modelo 
Mastercycler $^{\circledR}$ ep realplex2 (Eppendorf). Todas as amostras foram analisadas em triplicata.

\subsection{Microarranjos de oligonucleotídeos}

\subsubsection{Montagem e confecção}

Primeiramente, uma lista com as 1.345 CDS (sequências codificadoras) elucidadas pelo sequenciamento completo do genoma da cepa Sheila Smith de $R$. rickettsii (NC_009882) foi submetida ao desenho de oligonucleotídeos. Para tal, foram utilizados os serviços da GE Healthcare, disponíveis através do programa eArray (Agilent Technologies, EUA; http://earray.chem.agilent.com). Foi solicitado o desenho de 10 oligonucleotídeos por CDS, sendo gerada uma lista de 13.405 oligonucleotídeos. Em seguida, os filtros de qualidade recomendados pela Agilent Technologies foram aplicados manualmente, gerando uma segunda lista com 13.049 oligonucleotídeos. Os 13.049 oligonucleotídeos representando 99,5\% do genoma de R. rickettsii (pelo menos 6 oligonucleotídeos por CDS) foram utilizados para a confecção dos microarranjos, formato $8 \times 15 \mathrm{k}$, pela Agilent Technologies. Apenas seis genes, que codificam as proteínas hipotéticas A1G_00350, A1G_04065, A1G_06365, A1G_07320 e A1G_02055, além do gene que codifica a enzima pterina-4-alfa-carbinolamina desidratase (PHS) putativa não estão representados. Uma descrição detalhada nos microarranjos pode ser encontrada na base de dados do NCBI Gene Expression Omnibus (GEO) com o número de acesso GPL16681.

\subsubsection{Síntese e marcação de cDNA}

\subsubsection{Padronização dos procedimentos}

Primeiramente, avaliamos quatro diferentes procedimentos para a síntese e marcação das amostras de cDNA de $R$. rickettsii. Para esse fim, utilizamos o RNA extraído de células BME26 mantidas a $28^{\circ} \mathrm{C}$ ou $34^{\circ} \mathrm{C}$ por $48 \mathrm{~h}$ após a infecção por $R$. rickettsii. O RNA total de três garrafas (triplicata biológica) de células infectadas de cada condição analisada foi reunido formando uma amostra pool. O RNA contido 
na amostra pool foi tratado com DNase RQ1 (Promega), conforme especificações do fabricante, e utilizado para a síntese e marcação do cDNA.

Três variáveis foram avaliadas: (i) a necessidade da remoção do RNAm eucariótico das amostras para evitar a interferência desse material na marcação do RNAm procariótico, (ii) a necessidade de amplificação do cDNA confeccionado; e (iii) a eficiência de dois diferentes kits de marcação (Figura 2).

Figura 2 - Fluxograma dos quatro diferentes procedimentos utilizados para a preparação das amostras de cDNA para a hibridização nos microarranjos.

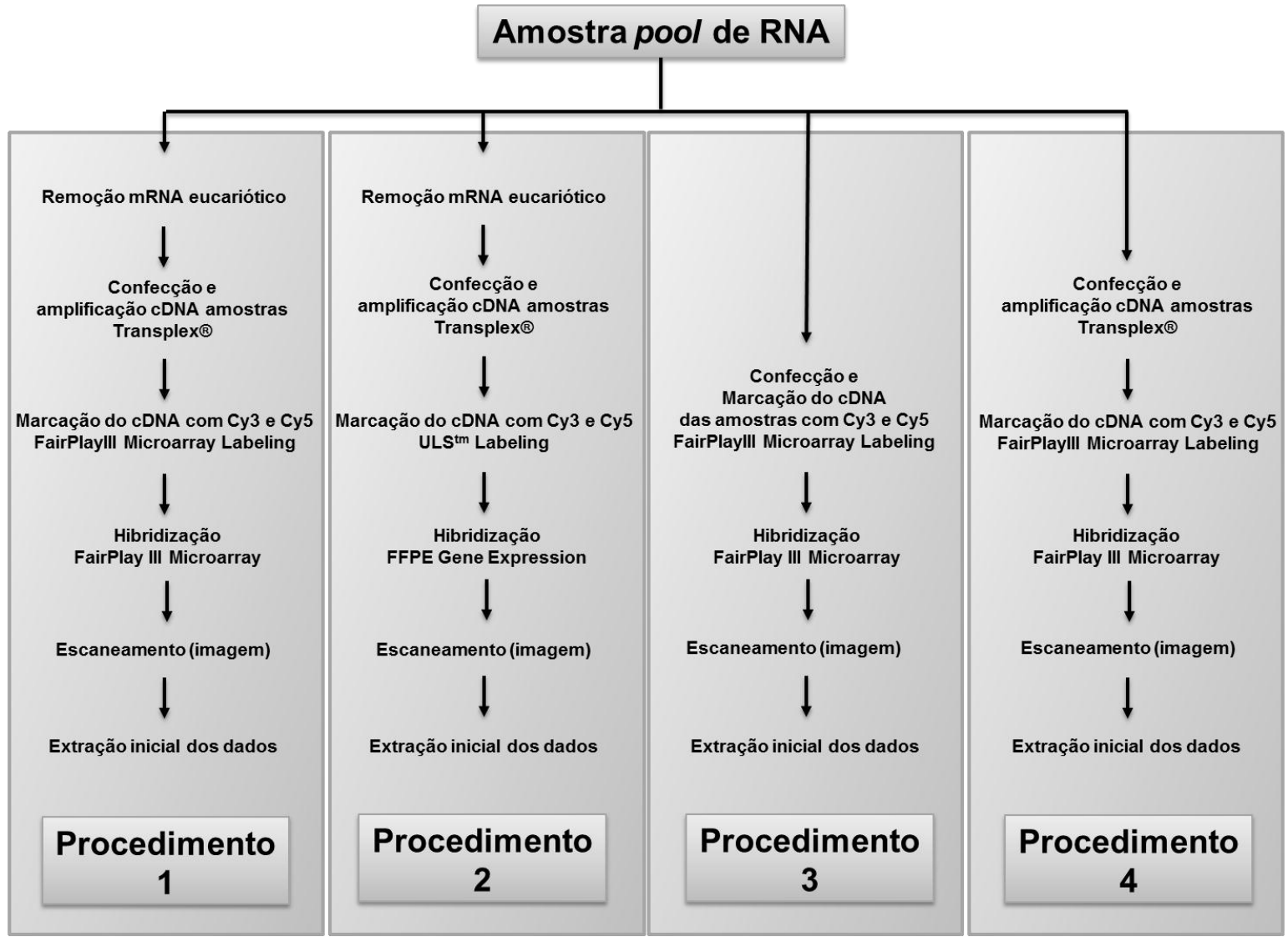

Para a remoção do RNAm eucariótico, procedimento adotado para a preparação das amostras obtidas pelos procedimentos 1 e 2 , utilizamos o kit Oligotex $^{\circledR}$ mRNA (QIAGEN, EUA). A síntese de cDNA seguida de amplificação, empregada na preparação das amostras resultantes dos procedimentos 1, 2 e 4, foi realizada pela utilização do Transplex ${ }^{\circledR}$ Whole Transcriptome Amplification Kit (Sigma-Aldrich). Após a amplificação, o kit illustra GFX ${ }^{\mathrm{TM}}$ PCR DNA and Gel Band Purification (GE Healthcare) foi utilizado para a purificação do cDNA, seguindo-se o protocolo do 
fabricante. As amostras obtidas pelo procedimento 3 não foram amplificadas e a síntese de cDNA foi realizada com o FairPaly III Labeling Kit (Agilent Technologies).

As concentrações de cDNA de todas as amostras foram determinadas em um espectrofotômetro (modelo NanoDrop-1000, Thermo Fisher Scientific). Quinhentos ng de cDNA de cada amostra foram utilizados para a marcação independente com Cy3 ou Cy5 de modo a obterem-se de réplicas técnicas (dye swap). Para a marcação do cDNA das amostras obtidas pelo procedimento 3 , utilizamos 0 Genomic DNA ULS ${ }^{T M}$ (Kreatech's Universal Linkage System) Labeling Kit (Agilent Technologies). O cDNA das demais amostras foi marcado com o FairPaly III Labeling Kit (Agilent Technologies). Todos os procedimentos utilizados neste experimento seguiram as especificações dos respectivos fabricantes.

Após a marcação, as concentrações de cDNA de todas as amostras foram determinadas em um espectrofotômetro (modelo NanoDrop-1000, Thermo Fisher Scientific). As concentrações obtidas foram empregadas para calcular o rendimento de marcação, conforme descrito na fórmula abaixo:

Rendimento de marcação = $340 \times$ pmol por $\mu \mathrm{L}$ de fluoróforo

(ng por $\mu \mathrm{L}$ de cDNA x 1000) - pmol por $\mu g$ de fluoróforo

As amostras com rendimento de marcação $\geq 825 \mathrm{ng}$ foram utilizadas para a hibridização com os microarranjos de oligonucleotídeos.

\subsubsection{Amostras destinadas à determinação da expressão gênica diferencial de $R$. rickettsii}

Para a análise do perfil transcricional de $R$. rickettsii infectando carrapatos $A$. aureolatum, 200 ng do RNA extraído dos órgãos de sete fêmeas de cada grupo biológico (G1, G2 e G3, descritos no item 3.5), apresentando entre 1,60 x $10^{8}$ e 2,20 x $10^{8}$ bactérias, foi reunido em uma amostra pool. Cada exemplar contribuiu de forma equitativa (200 ng) para a composição da amostra pool. Após o tratamento, o RNA resultante foi utilizado como molde para transcrição e amplificação com o MessageAmp ${ }^{\mathrm{TM}}$ II-Bacteria Kit Prokaryotic RNA Amplification (Life Technologies), 
conforme descrito pelo fabricante. Esse kit tem especificidade para RNA de procariotos e apresentou um rendimento de amplificação superior ao do TransPlex ${ }^{\circledR}$ Whole Transcriptome Amplification Kit (Sigma-Aldrich) utilizado anteriormente.

Em seguida, as concentrações RNA amplificado (aRNA) das amostras foram determinadas em um espectrofotômetro (modelo NanoDrop-1000, Thermo Fisher Scientific). Um $\mu \mathrm{g}$ de aRNA de cada réplica biológica foi marcado independentemente com os fluoróforos Cy3 ou Cy5 (dye swap) utilizando-se o Genomic DNA ULS ${ }^{\text {TM }}$ (Kreatech's Universal Linkage System) Labeling Kit (Agilent Technologies). O rendimento da marcação foi calculado conforme descrito no item 3.9.2.1. Foram utilizadas duas réplicas biológicas e duas réplicas técnicas (dye swap) para cara condição analisada.

O RNA proveniente de carrapatos $A$. aureolatum não infectados foi amplificado conforme descrito anteriormente e utilizado como controle de hibridização não específica com os microarranjos.

\subsubsection{Hibridização, lavagem e escaneamento}

A hibridização e lavagem dos microarranjos seguiram as instruções da Agilent Technologies contidas no manual do FairPlaylll Microarray kit. Resumidamente, cada par de amostras de cDNA a ser analisado foi combinado e aplicado em um microarranjo. Em seguida, as lâminas foram transferidas para um forno de hibridização a $65^{\circ} \mathrm{C}$ onde permaneceram por $17 \mathrm{~h}$ com rotação a $10 \mathrm{rpm}$. Ao final do processo de hibridização, as lâminas foram submetidas a lavagens com Wash Buffer 1 e 2 (Agilent Technologies) por 1 min cada, sob agitação branda. $O$ excesso de água foi removido mergulhando-se as lâminas em acetonitrila. Em seguida, as lâminas foram imersas em Stabilization Buffer por $30 \mathrm{~s}$.

Após a lavagem, os microarranjos utilizados para a padronização dos procedimentos de síntese e marcação de cDNA seguiram imediatamente para a varredura no escâner Axon GenePix 4000B (Molecular Devices, EUA). As imagens dos microarranjos foram obtidas com o auxílio do programa GenePix Pro 6.0 (Molecular Devices). A varredura dos microarranjos utilizados na determinação do perfil de expressão gênica diferencial de $R$. rickettsii foi realizada em um escâner High-Resolution C (Agilent Technologies). 
Todas as imagens foram processadas pelo programa Feature Extraction 10.5 (Agilent Technologies). Esse programa analisa se todos os parâmetros de qualidade da marcação e hibridização foram atingidos. O mesmo programa localiza e aplica, automaticamente, a grade para a captação dos dados de fluorescência de cada canal em cada ponto do microarranjo, além de determinar as razões de intensidade de fluorescência entre os canais.

\subsubsection{Análise dos dados}

Após a obtenção dos dados brutos de fluorescência em cada canal pelo software Feature Extraction 10.5 (Agilent Technologies), os mesmos foram normalizados com o algoritmo loess (Ballman et al., 2004). As razões de intensidades normalizadas de G2 (carrapatos não alimentados incubados a $35^{\circ} \mathrm{C}$ ) versus $\mathrm{G} 1$ (carrapatos não alimentados incubados a $25^{\circ} \mathrm{C}$ ) (i) e G3 (carrapatos alimentados) versus G2 (carrapatos não alimentados incubados a $35^{\circ} \mathrm{C}$ ) (ii) foram utilizadas para calcular o fold-change (soma dos valores de fold-change de todas as sondas representando um gene dividido pelo número total de sondas representando o mesmo gene). Uma CDS foi considerada modulada somente quando $65 \%$ das sondas (oligonucleotídeos) exibiram um fold-change maior do que 1,5 e menor do que -1,5 nas duas réplicas biológicas e nas duas duplicatas técnicas. As análises dos dados foram realizadas em colaboração com o Prof. Dr. André Fujita (Instituto de Matemática e Estatística, IME - USP).

O conjunto de dados completo de expressão destes experimentos é público e está disponível de acordo com o guia MIAME (Minimum Information About a Microarray Experiment) (Brazma et al., 2001), com número de acesso GSE44349.

\subsection{Análise in silico das CDS de proteínas moduladas pela temperatura e alimentação sanguínea}

As sequências de nucleotídeos de todas as CDS codificadoras de proteínas hipotéticas detectadas como moduladas foram submetidas a uma análise in silico contra 0 banco de dados CDD (Conserved Domain Database http://www.ncbi.nlm.nih.gov/cdd) para a identificação de domínios conservados e similaridade com proteínas previamente anotadas. Neste banco de dados, os 
alinhamentos são realizados com base nos domínios conservados de proteínas de diferentes organismos, incluindo também domínios descritos por análises tridimensionais da base de dados MMDB (Molecular Model Database).

\subsection{Validação dos dados de microarranjos por reação em cadeia de polimerase quantitativa precedida por transcrição reversa (RT- qPCR)}

\subsubsection{Oligonucleotídeos}

Os oligonucleotídeos específicos para 17 genes com expressão gênica modulada de acordo com os dados de microarranjos foram desenhados utilizando-se o programa Primer3 4.0 <http://primer3.wi.mit.edu/> (Rozen, Skaletsky, 2000) e sintetizados pela empresa Life Technologies (Apêndice A).

\subsubsection{Síntese e amplificação de cDNA}

Um $\mu \mathrm{g}$ do RNA total extraído de órgãos de fêmeas de $A$. aureolatum de cada grupo biológico (G1, G2 e G3, descritos no item 3.5), apresentando entre 1,51 x $10^{8}$ e 3,06 $\times 10^{8}$ riquétsias, foi submetido ao tratamento com DNase RQ1 (Promega). Foram utilizadas cinco réplicas biológicas individuais de cada grupo. Após o tratamento, o RNA foi utilizado para as reação de transcrição reversa e amplificação com o kit MessageAmp ${ }^{\mathrm{TM}}$ II-Bacteria Kit Prokaryotic RNA Amplification (Life Technologies), conforme descrito anteriormente (item 3.9.2.2).

\subsection{3 qPCR}

Para cada reação foram utilizados $8 \mu \mathrm{L}$ do Kit Maxima ${ }^{\circledR}$ SYG Green/ROX qPCR Master Mix (2X) (Thermo Fisher Scientific), 10 pmols de cada um dos oligonucleotídeos específicos, $1 \mu \mathrm{g}$ das amostras de aRNA e quantidade suficiente de água ultrapura autoclavada para completar $16 \mu \mathrm{L}$. Utilizamos o termociclador StepOnePlus ${ }^{\mathrm{TM}}$ (Life Technologies), com o seguinte programa térmico: $95^{\circ} \mathrm{C}$ por 2 min, 40 ciclos de $95^{\circ} \mathrm{C}$ por $15 \mathrm{~s}, 60{ }^{\circ} \mathrm{C}$ por $15 \mathrm{~s}, 72{ }^{\circ} \mathrm{C}$ por $30 \mathrm{~s}$. Previamente às análises de expressão gênica diferencial, a eficiência de cada par de oligonucleotídeos foi determinada avaliando-se a amplificação obtida (Ct) com 
diferentes concentrações de aRNA. Todas as amostras foram analisadas em triplicata.

\subsubsection{Análise dos dados}

A equação de $2^{-\Delta \Delta C t}$ (Livak, Schmittgen, 2001) foi aplicada para calcular a expressão relativa de cada gene analisado, sendo que a quantidade de aRNA das amostras foi normalizada de acordo com o nível de expressão do gene codificador da metionil tRNA sintetase. Para a análise dos efeitos da elevação da temperatura, a condição utilizada como calibradora foi G1 e para a análise dos efeitos da alimentação, a condição calibradora foi G2. A identificação das amostras discrepantes (outliers) foi realizada considerando-se:

$$
\begin{aligned}
& <\mathrm{J} 1-1,5 \mathrm{x} d \mathrm{~J} \\
& >\mathrm{J} 3+1,5 \mathrm{x} d \mathrm{~J}
\end{aligned}
$$

Onde $\mathrm{J}(\mathrm{J} 1, \mathrm{~J} 2, \mathrm{~J} 3)$ são amostras diferentes e $\mathrm{dJ}=\mathrm{J} 3$ - J1. Em seguida, as medianas foram estatisticamente testadas pelo teste de Wilcoxon.

\subsection{Análise do perfil de expressão gênica de $R$. rickettsii em glândulas salivares e intestinos de carrapatos adultos por RT- qPCR microfluídica}

Para analisar o efeito da temperatura e da alimentação sanguínea sobre o perfil de expressão de genes de $R$. rickettsii em tecidos específicos (glândulas salivares e intestinos) de fêmeas e de machos de $A$. aureolatum dos grupos biológicos G1, G2 e G3 (descritos no item 3.5), utilizamos a metodologia de RT-qPCR microfluídica em larga escala.

A mesma metodologia foi utilizada para a determinação do perfil transcricional de $R$. rickettsii infectando células BME26 (item 3.4). Para tal, monocamadas de BME26 foram infectadas com $R$. rickettsii utilizando-se $\mathrm{MOI}$ de 3,0. Após a incubação por 48 h a $34{ }^{\circ} \mathrm{C}$, as monocamadas foram processadas conforme descrito no item 3.4. Cinco réplicas biológicas foram obtidas e utilizadas nos experimentos de RT-qPCR. 


\subsubsection{Oligonucleotídeos}

Noventa e cinco oligonucleotídeos específicos para genes de $R$. rickettsii, selecionados com base nos resultados dos microarranjos ou envolvidos na virulência da bactéria conforme dados da literatura (Beckwith, 2013; Chan et al., 2009; Heinzen et al., 1993; Hendrick, Hartl, 1993; Li, Walker, 1998; Rahman et al., 2005; Rahman et al., 2013; Rikihisa, Lin, 2010; Uchiyama et al., 2006; Uchiyama, 2012; Walker et al., 2001; Winkler, 1976), foram desenhados utilizando-se o programa Primer3 4.0 <http://primer3.wi.mit.edu/> (Rozen, Skaletsky, 2000) e sintetizados pela Life Technologies (Apêndice B).

\subsubsection{Síntese e amplificação de cDNA}

Duzentos ng de RNA total de glândulas salivares ou intestinos de machos e de fêmeas de $A$. aureolatum dos três grupos biológicos (G1, G2 e G3, descritos no item 3.5) ou de células BME26 (descritas no item 3.9.2.1) foram utilizados para a confecção do cDNA com a transcriptase reversa M-MLV (Life Technologies), seguindo-se o protocolo descrito pelo fabricante. Previamente à síntese de cDNA, todas as amostras de RNA foram tratadas com RQ1 RNase-Free DNase (Promega) para a remoção de DNA genômico residual. Duas amostras de cDNA foram sintetizadas da mesma maneira acima descrita a partir de uma amostra pool de RNA de glândulas salivares e de intestinos de machos e de fêmeas de $A$. aureolatum não infectados e amostras de RNA de células BME26 não infectadas, para serem utilizadas como controle das reações. Além disso, uma amostra pool contendo $2 \mu \mathrm{L}$ de cada uma das 135 amostras de cDNA foi empregada para a obtenção das curvas de eficiência (pontos gama) para cada par de oligonucleotídeos. As amostras de cDNA foram armazenadas a $-20^{\circ} \mathrm{C}$ até utilização nas reações de pré-amplificação.

Para a realização da pré-amplificação específica de cDNA, uma solução contendo todos os 95 pares de oligonucleotídeos (concentração final de $0,2 \mu \mathrm{M}$ ) foi preparada. Uma mistura contendo $5 \mu \mathrm{L}$ do TaqMan PreAmp Master Mix 2X (Life Technologies) e 2,5 $\mu \mathrm{L}$ do pool de oligonucleotídeos foi preparada e, em seguida, adicionada a 2,5 $\mu \mathrm{L}$ de cada amostra de cDNA contidas em poços de uma placa. A placa foi centrifugada a $1000 \mathrm{xg}$ por 2 min a $4{ }^{\circ} \mathrm{C}$ e transferida para um termociclador Mastercycler ${ }^{\circledR}$ Gradient (Eppendorf), onde as reações foram realizadas com 0 
seguinte programa térmico: $95^{\circ} \mathrm{C}$ por 10 min e 14 ciclos a $95^{\circ} \mathrm{C}$ por 15 s e $60{ }^{\circ} \mathrm{C}$ por 4 min. As amostras de cDNA pré-amplificadas foram diluídas em $40 \mu \mathrm{L}$ de $\mathrm{H}_{2} \mathrm{O}$ ultrapura tratada com dietilpirocarbonato (DEPC) e congeladas a $-20{ }^{\circ} \mathrm{C}$ até a utilização.

\subsection{3 qPCR}

A PCR quantitativa (qPCR) foi realizada utilizando-se arranjos dinâmicos de microfluídica para qPCR (formato 96x96, Fluidigm Corporation, EUA), seguindo-se rigorosamente as especificações do fabricante (Fluidigm Corporation). Resumidamente, o óleo de controle de uma seringa de distribuição foi adicionado a cada uma das duas válvulas presentes no arranjo dinâmico. Em seguida, a placa foi posicionada em um IFC Controler HX (Fluidigm Corporation), equipamento responsável pela aplicação da pressão e distribuição dos fluidos nos microcanais controladores do arranjo. Uma mistura contendo $368 \mu \mathrm{L}$ de TaqMan Gene Expression Master Mix 2X (Life Technologies), $36 \mu \mathrm{L}$ de DNA Binding Dye Sample Loading Reagent 20X (Fluidigm Corporation), $36 \mu \mathrm{L}$ de EvaGreen 20X (Biotium, EUA) e $100 \mu \mathrm{L}$ de Tris-EDTA $1 \mathrm{X}$ foi preparada. Cinco $\mu \mathrm{L}$ dessa mistura foram adicionados a 1,7 $\mu \mathrm{L}$ de cada amostra de cDNA pré-amplificado. Para a obtenção de uma mistura de oligonucleotídeos, $385 \mu \mathrm{L}$ do Assay Loading Reagent 2X (Fluidigm Corporation) foram adicionados a $193 \mu \mathrm{L}$ de TE $1 \mathrm{X}$. Da mesma maneira, $5 \mu \mathrm{L}$ dessa mistura foram adicionados a 1,7 $\mu \mathrm{L}$ de cada par de oligonucleotídeos a ser analisado. As preparações de cDNA e de oligonucleotídeos foram distribuídas em poços presentes em cada face lateral do arranjo dinâmico.

Mais uma vez, o arranjo seguiu para o equipamento IFC Controler HX por $1 \mathrm{~h}$ para a aplicação da pressão e distribuição das amostras e oligonucleotídeos. Em seguida, o arranjo foi transferido para o termociclador BioMark (Fluidigm Corporation) para que a realização das reações, seguindo o programa térmico descrito na Tabela 1. 
Tabela 1 - Programa térmico das qPCR realizadas no equipamento BioMark (Fluidigm Corporation).

\begin{tabular}{cccc}
\hline & Temperatura $\left({ }^{\circ} \mathrm{C}\right)$ & $\begin{array}{c}\text { Tempo } \\
\text { (minutos) }\end{array}$ & Ciclos \\
\hline \multirow{2}{*}{ Mix térmico } & 50 & 120 & \\
& 70 & 1800 & 1 \\
& 25 & 600 & \\
UNG e Hot Start & 50 & 120 & 1 \\
& 95 & 600 & \\
Ciclo de PCR & 95 & 15 segundos & 35 \\
\hline Curva de Melting & 60 & 60 segundos & \\
\hline
\end{tabular}

\subsubsection{Análise dos dados}

Os dados de fluorescência gerados em cada reação foram tecnicamente normalizados com base na emissão da sonda controle (ROX), contida no $2 X$ TaqMan ${ }^{\circledR}$ PreAmp Master Mix, (Life Technologies). Os Ct corrigidos foram extraídos pelo software Fluidigm ${ }^{\oplus}$ Real-Time PCR Analysis version 3 (Fluidigm Corporation).

A escolha dos genes de referência foi baseada nos resultados de $\mathrm{Ct}$ analisados pelo programa NormFinder <http://www.mdl.dk/publications normfinder.htm> (Andersen et al., 2004). Uma CDS foi considerada modulada somente quando o mesmo comportamento foi observado em todas as réplicas biológicas analisadas dos experimentos in vivo e in vitro, utilizando-se um fold-change mínimo de $( \pm)$ 1,5. Além deste parâmetro, utilizamos uma análise de variância para excluir os genes com comportamento discrepante dentro do conjunto de amostras do mesmo grupo biológico (cut-off de variância: < 50\%).

Após a normalização inicial, os dados seguiram para o programa $\mathrm{MeV}$ (MultiExperient Viewer) <http://www.tm4.org/mev/>, no qual analisamos o perfil transcricional do conjunto de dados em todas as condições analisadas. $O$ teste $t$ de Student foi aplicado às medianas para avaliar se a diferença estatística entre os grupos analisados era significativa. 


\section{RESULTADOS}

\subsection{Determinação do perfil de expressão gênica global de Rickettsia rickettsii por microarranjos de oligonucleotídeos}

\subsubsection{Padronização dos procedimentos para a síntese e marcação de cDNA}

Para estabelecermos uma metodologia eficiente para a síntese e marcação de cDNA de $R$. rickettsii buscamos, primeiramente, um modelo in vitro de células de carrapato para a amplificação da bactéria e obtenção de RNA em grande quantidade. Para esse fim, um inóculo da cepa Taiaçu de $R$. rickettsii em células Vero foi adicionado a uma monocamada de células embrionárias do carrapato Rhipicephalus (Boophilus) microplus (BME26). Observamos que $R$. rickettsii foi capaz de infectar essa linhagem celular em todas as condições analisadas (temperatura de incubação de $28{ }^{\circ} \mathrm{C}$ e $34{ }^{\circ} \mathrm{C}$; meio de cultura com pH 7,2) e em todas as diluições do inóculo (de 1:1 até 1:1000 com base de diluição de 10x) utilizadas (dados não mostrados). Para a visualização das células infectadas, dois métodos de coloração foram utilizados, o Panóptico (Figuras 3A e B) ou o Gimenez (Figura 3C e D). Este último mostrou-se mais eficiente para a observação de riquétsias infectando as células BME26 e foi adotado como padrão pelo nosso grupo de pesquisa. Um efeito citopático foi deflagrado pela infecção por $R$. rickettsii após $60 \mathrm{~h}$ em todas as condições analisadas e diluições do inóculo inicial. Um efeito citopático também é observado após 60 h de infecção de células Vero por essa cepa de $R$. rickettsii (Prof. Dr. Marcelo Bahia Labruna - comunicação pessoal). 

Figura 3 - Observação de células BME26 infectadas com $R$. rickettsii por
microscopia ótica.
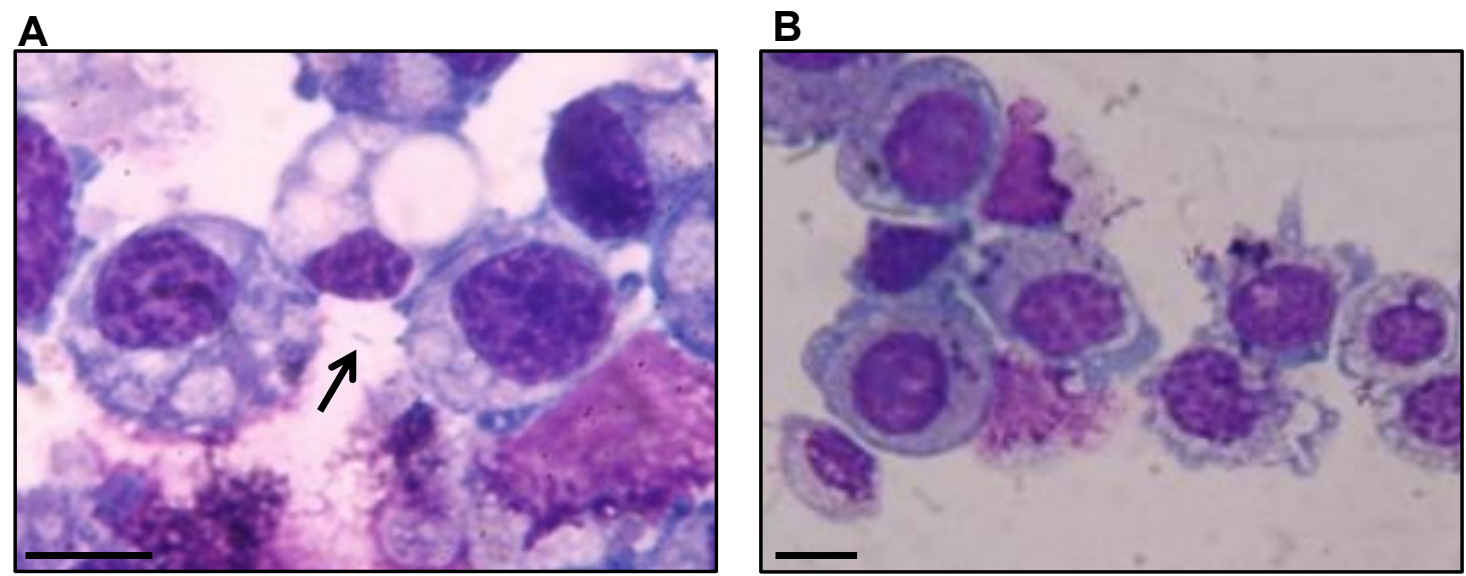

C

D
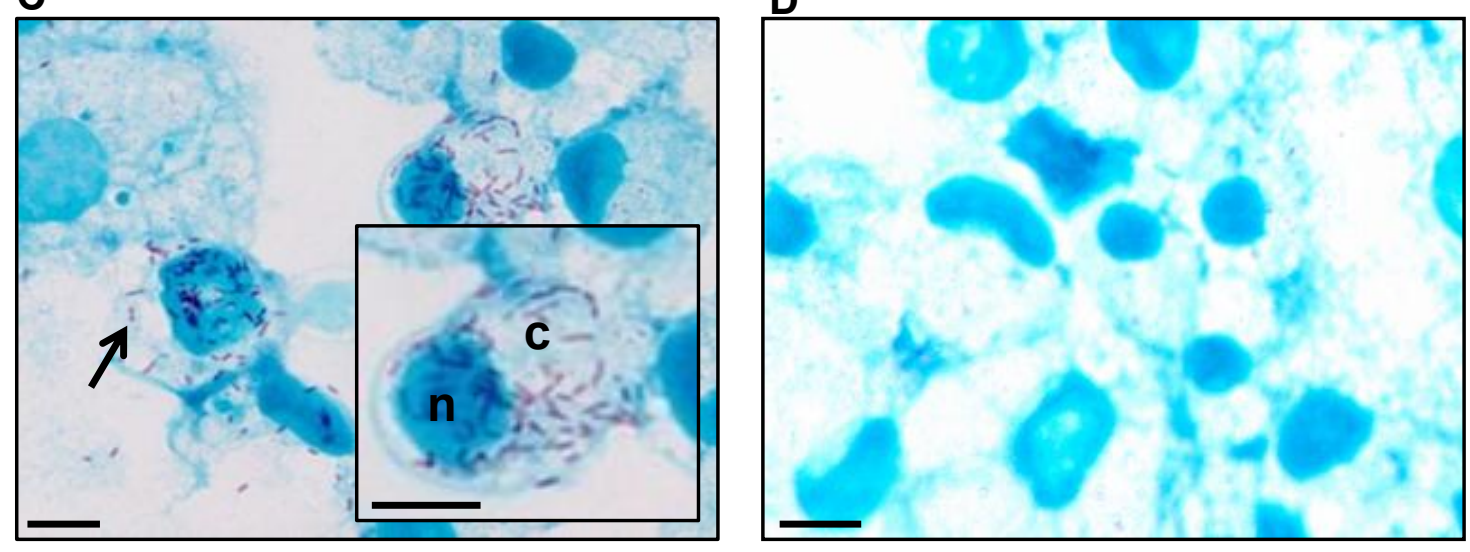

Nota: As células BME26 infectadas por $R$. rickettsii foram coradas pelos métodos de Panóptico (A) ou Gimenez (C) e observadas sob microscópio Zeiss-Axiofhot (Zeiss) com aumento de 1000x. As células apresentadas correspondem ao ponto de $72 \mathrm{~h}$ após a inoculação de riquétsias. Como controle, células não infectadas foram coradas também com Panóptico (B) ou Gimenez (D). As riquétsias (bastonetes de coloração púrpura, setas pretas) foram visualizadas fora da célula (A) ou no interior das células infectadas (C). n: núcleo; c: citoplasma; barra preta: $10 \mu \mathrm{m}$.

Após comprovar a capacidade de $R$. rickettsii de infectar células BME26, determinamos a sua curva de crescimento nessa linhagem celular, de modo a obtermos RNA de bactérias na fase logarítmica de crescimento. Para tal, um inóculo de $R$. rickettsii em células BME26 foi adicionado a novas monocamadas de células BME26 incubadas a $34^{\circ} \mathrm{C}$. O DNA genômico extraído logo após a adição do inóculo (tempo $0 \mathrm{~h}$ ) e após 12, 24, 36, 48 e $60 \mathrm{~h}$, a $34{ }^{\circ} \mathrm{C}$ e pH 7,4, foi utilizado para a quantificação do número de riquétsias por qPCR com sonda TaqMan ${ }^{\circledR}$ específica para o gene gltA (Figura 4). Observamos um aumento de uma ordem de grandeza no número de bactérias a cada $24 \mathrm{~h}$. Novamente, após 60 h do início da infecção, foi observado o descolamento de um grande número de células BME26 do tapete celular (efeito citopático). 
Figura 4 - Curva de crescimento de $R$. rickettsii em células BME26.

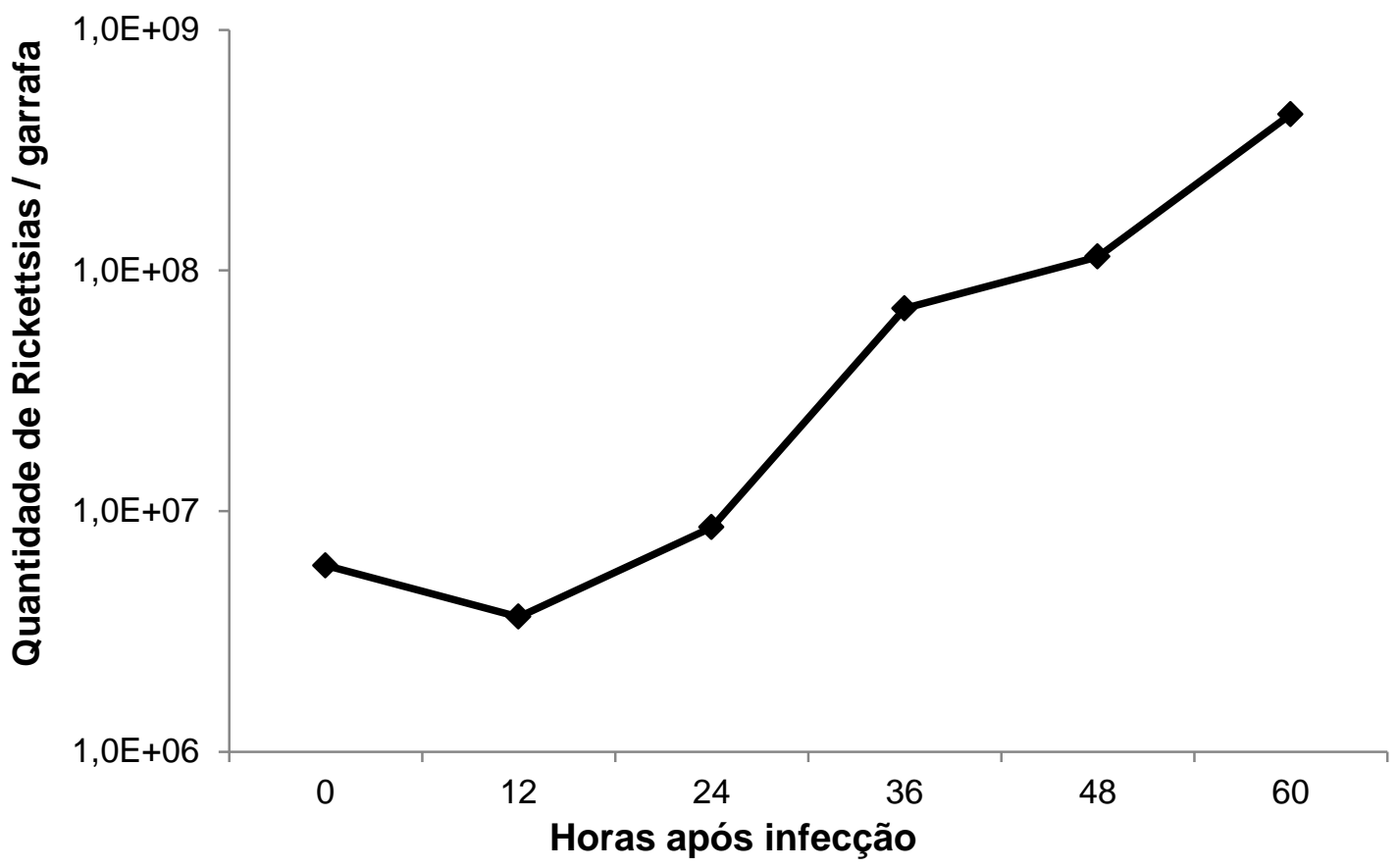

Nota: As células BME26 foram infectadas e o número de bactérias logo após a adição do inóculo (tempo $0 \mathrm{~h}$ ) e após 12, 24, 36, 48 e $72 \mathrm{~h}$ foi determinado por qPCR com sonda TaqMan específica para o gene glt $A$ de $R$. rickettsii. Cada ponto da curva representa uma média ( $\log _{10}$ ) da quantidade total de $R$. rickettsii de três garrafas (triplicata biológica).

Após a determinação da curva de crescimento de $R$. rickettsii, foi possível obter uma quantidade de RNA suficiente para a padronização dos procedimentos a serem adotados na síntese e marcação de cDNA. Para esse fim, utilizamos o RNA extraído de células BME26 mantidas a $28^{\circ} \mathrm{C}$ ou $34^{\circ} \mathrm{C}$ por $48 \mathrm{~h}$ após a infecção por R. rickettsii. O RNA total de três garrafas (triplicata biológica) de células infectadas de cada condição analisada foi reunido formando uma amostra pool. A primeira variável a ser avaliada foi a necessidade da remoção do RNA eucariótico, utilizandose para isso o kit Oligotex ${ }^{\circledR}$ RNAm (QIAGEN). Também avaliamos a necessidade de amplificar o cDNA após a transcrição reversa. A síntese e amplificação de cDNA foi realizada utilizando-se 0 kit Transplex ${ }^{\circledR}$ Whole Transcriptome Amplification Kit (Sigma-Aldrich). Por fim, comparamos a eficácia de dois kits diferentes de marcação: o Genomic DNA ULS ${ }^{\text {TM }}$ (Kreatech's Universal Linkage System) Labeling Kit (Agilent Technologies) e o FairPaly III Labeling Kit (Agilent Technologies) (vide Figura 2 no item Material e Métodos). Ao final do processamento, cada par de amostras foi hibridizado com os microarranjos. A imagem obtida após o escaneamento (Figura 5) 
demonstrou que a intensidade de fluorescência foi maior nas amostras submetidas à amplificação (Figuras 5A, 5B e 5D) do que naquelas não submetidas a esse procedimento (Figura $\mathbf{5 C}$ ). Já a remoção do RNAm eucariótico pareceu não ser fundamental, uma vez que a intensidade da fluorescência obtida pelos procedimentos 1 (RNAm eucariótico removido; Figuras 5A) e 4 (RNAm eucariótico não removido; Figuras 5D) não apresentou grandes diferenças. Por fim, o procedimento 2, o único no qual as amostras foram submetidas à marcação com o Genomic DNA ULS ${ }^{\mathrm{TM}}$ Labeling Kit (Figura 5B), foram as que apresentaram a maior intensidade de fluorescência.

Figura 5 - Imagem gerada pelo escaneamento dos microarranjos de oligonucleotídeos após a hibridização com amostras de cDNA de $R$. rickettsii preparadas com diferentes procedimentos.

A

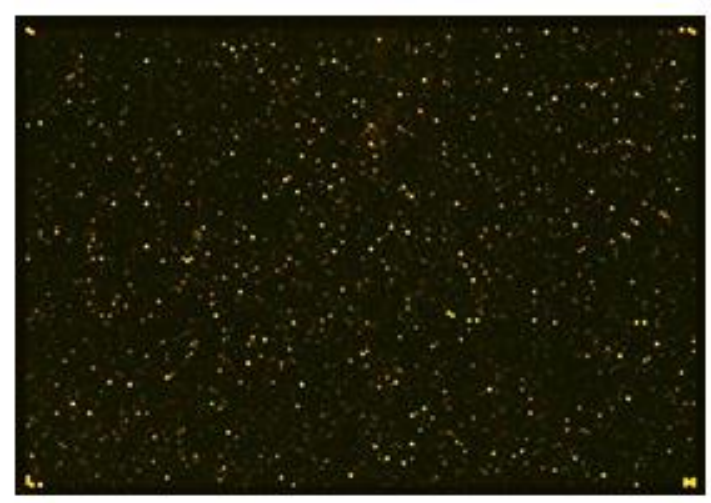

C

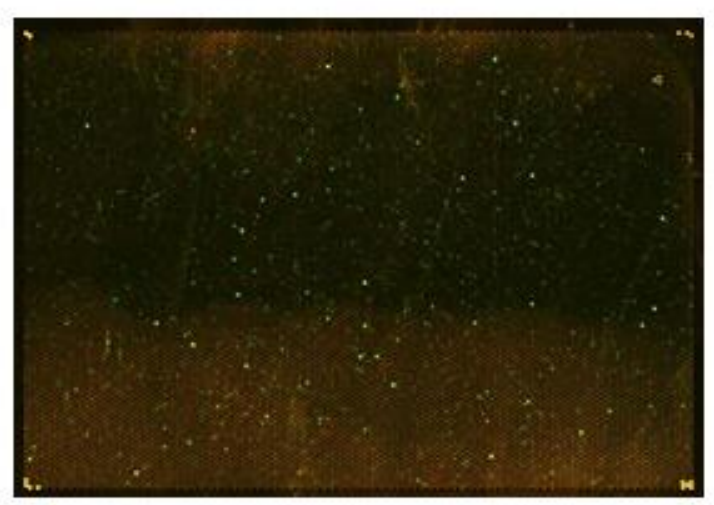

B

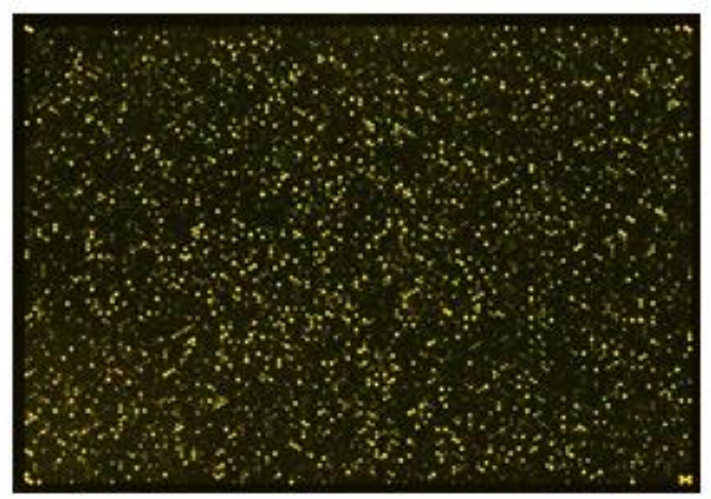

D

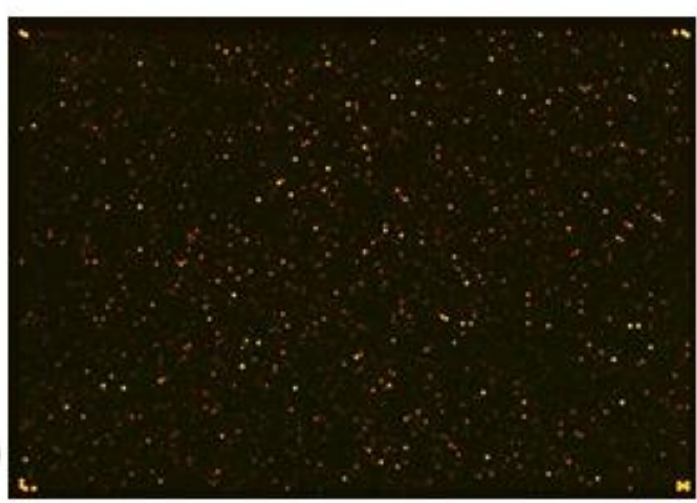

Nota: A. Amostras de cDNA preparadas com a remoção de RNAm eucariótico, com a amplificação de cDNA e com a marcação com o FairPlaylll Labeling Kit. B. Amostras de cDNA preparadas com a remoção de RNAm eucariótico, com a amplificação de cDNA e com a marcação com o Genomic DNA ULS $^{T M}$ Labeling Kit. C. Amostras de cDNA preparadas sem a remoção de RNAm eucariótico, sem a amplificação de cDNA e com a marcação com o FairPlaylll Labeling Kit. D. Amostras de cDNA preparadas sem a remoção de RNAm eucariótico, com a amplificação de cDNA e com a marcação com o FairPlayllI Labeling Kit. 
Os parâmetros relacionados à qualidade de hibridização, estabelecidos pelo programa Feature Extraction 10.5 (Agilent Technologies), também apontaram o procedimento 2 como o mais eficiente na confecção e marcação dos cDNAs das amostras. Além da intensidade de fluorescência das amostras submetidas ou não à remoção de RNAm eucariótico ter sido similar, a recuperação de RNA com o kit Oligotex ${ }^{\circledR}$ mRNA (QIAGEN) apresentou grandes variações entre amostras. Dessa forma, para as análises subsequentes, o RNA total extraído de células BME26 ou de carrapatos infectados por $R$. rickettsii não foi submetido à remoção do RNA eucariótico, mas foram submetidas ao procedimento de amplificação. Além disso, utilizamos o Genomic DNA ULS ${ }^{\mathrm{TM}}$ Labeling Kit para a marcação com os fluoróforos.

\subsection{Efeitos de estímulos ambientais sobre o perfil transcricional de $R$. rickettsii infectando carrapatos Amblyomma aureolatum}

\subsubsection{Infecção experimental de carrapatos}

Conforme descrito no item Material e Métodos, cobaias foram inoculadas com um homogeneizado de baço e fígado de uma cobaia sacrificada previamente durante o pico febril da infecção por $R$. rickettsii. As larvas de $A$. aureolatum foram depositadas em câmaras de alimentação afixadas ao dorso de cobaias para que realizassem o repasto sanguíneo. Após a ecdise, as ninfas foram alimentadas da mesma forma descrita para as larvas, porém em coelhos. Por fim, após a ecdise para a fase adulta, os adultos foram subdivididos em três grupos. Os integrantes dos grupos denominados G1 e G2 não foram alimentados, tendo sido mantidos em incubadoras BOD com temperaturas ajustadas para $25^{\circ} \mathrm{C}$ e $35^{\circ} \mathrm{C}$, respectivamente, por três dias. Os integrantes do terceiro subgrupo, denominado G3, foram alimentados por três dias em cães. Ao final das etapas de incubação ou alimentação, os órgãos totais ou as glândulas salivares e os intestinos dos carrapatos dos três grupos foram dissecados e submetidos individualmente à extração simultânea de RNA total e DNA genômico (DNAg). O DNAg foi utilizado para a determinação do número total de bactérias nos tecidos por qPCR com sonda $\operatorname{TaqMan}^{\circledR}$ específica para o gene gltA de $R$. rickettsii.

Os resultados das qPCR nos mostraram que 100\% dos carrapatos estavam infectados por $R$. rickettsii. Além disso, observamos que o grupo de carrapatos 
alimentados (G3 - 7,2 \pm 4,0 $\times 10^{8}$ ) apresentou uma parcela de fêmeas (Figura 6A) e de machos (Figura 6B) com, em média, três vezes mais bactérias que os indivíduos dos grupos não alimentados e mantidos a $25^{\circ} \mathrm{C}\left(\mathrm{G} 1-2,2 \pm 2,0 \times 10^{8}\right)$ ou a $35^{\circ} \mathrm{C}$ (G2 - 3,4 $\pm 2,2 \times 10^{8}$ ). Os carrapatos do G2 também apresentaram um número significativamente maior de bactérias em relação aos do G1. Esses resultados demonstraram que tanto a elevação da temperatura quanto a aquisição da alimentação sanguínea aumentam significativamente a capacidade de proliferação da bactéria no carrapato-vetor.

Figura 6. Níveis de infecção em órgãos de carrapatos $A$. aureolatum adultos.
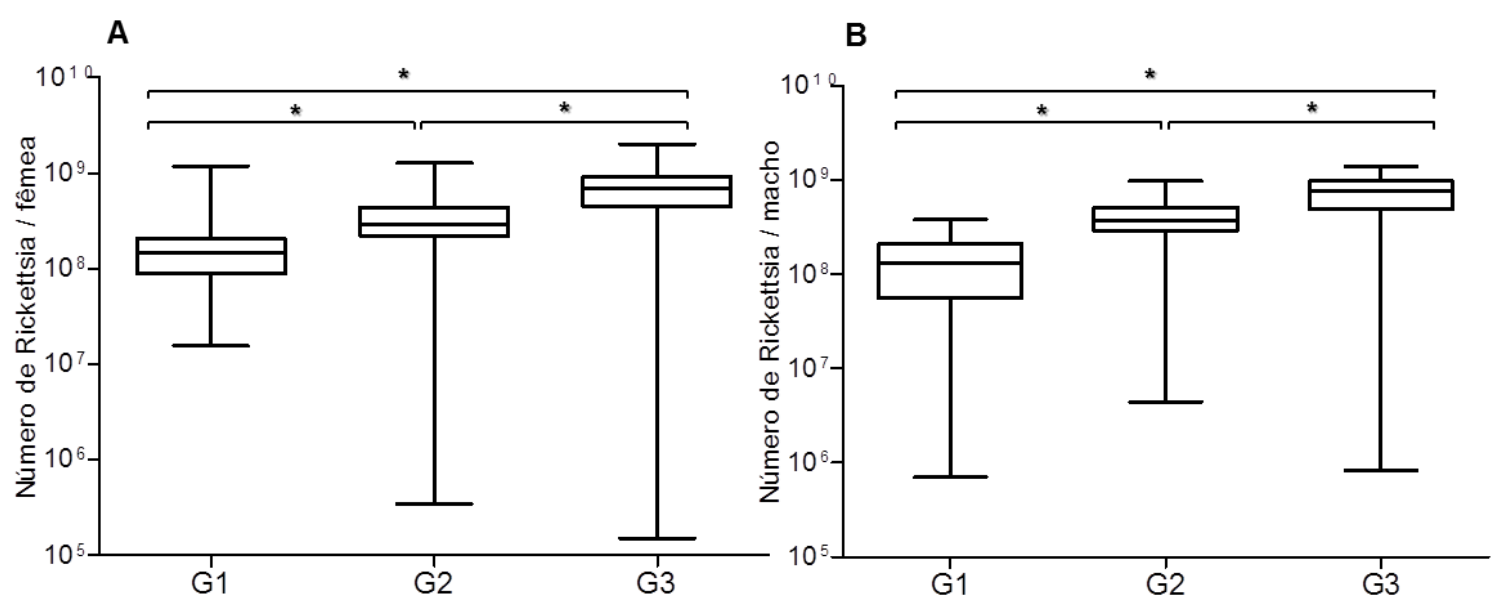

Nota: Para a quantificação dos níveis de infecção, o DNAg isolado dos órgãos de fêmeas $(A)$ e de machos (B) dos 3 grupos G1 e G2 (não alimentados e incubados a $25^{\circ} \mathrm{C}$ e $35^{\circ} \mathrm{C}$, respectivamente) e G3 (alimentados) foram analisados individualmente por qPCR com sonda TaqMan específica para o gene gltA de Rickettsia. As medianas estão representadas pelas linhas horizontais centrais de cada caixa. ${ }^{*} \mathrm{p}<0.001$ (test $t$ de Student).

4.2.2 Efeitos da temperatura sobre o perfil de expressão gênica global de $R$. rickettsii

Primeiramente, duas amostras pool de RNA do G1 (fêmeas não alimentadas incubadas a $25^{\circ} \mathrm{C}$ por 3 dias) e do G2 (fêmeas não alimentadas incubadas a $35^{\circ} \mathrm{C}$ por 3 dias) foram obtidas. Cada amostra foi constituída pelo RNA extraído dos órgãos de sete fêmeas apresentando entre $1,60 \times 10^{8}$ e 2,20 × $10^{8}$ bactérias. Após a síntese, amplificação e marcação do aRNA, as amostras foram hibridizadas com os microarranjos. Como controle, amostras de aRNA produzidas a partir do RNA de carrapatos não infectados também foram hibridizadas com os microarranjos. Os 
dados normalizados de fluorescência foram utilizados para a identificação das sequências codificadoras (CDS) de $R$. rickettsii moduladas pelo aumento da temperatura.

Das 1.304 CDS de $R$. rickettsii representadas no microarranjo, 44 (3,37\%) foram moduladas pela elevação da temperatura de $25^{\circ} \mathrm{C}$ para $35^{\circ} \mathrm{C}$, sendo que 25 foram induzidas e 19 foram reprimidas. Catorze (31,81\%) são CDS que codificam proteínas com função anotada (Tabela 2) e 30 (68,18\%) codificam proteínas hipotéticas (Apêndice $\mathbf{C}$ ). As CDS representadas pelos oligonucleotídeos que tiveram hibridização cruzada com o aRNA de carrapatos não infectados $(5,7 \%)$ foram excluídas das análises.

A elevação da temperatura em $10^{\circ} \mathrm{C}$ induziu a transcrição de CDS de enzimas ligadas ao processamento de RNA (dimetiladenosina transferase e endonuclease ligante de DNA/metaloproteína/AP putativa), além da CDS da recombinase XerD tirosina sítio específico. Importantemente, duas proteínas ligadas a adaptações do microrganismo a alterações de temperatura (proteína de choque frio e GrpE) foram induzidas. Por outro lado, CDS de enzimas relacionadas ao metabolismo energético (succinato semialdeído desidrogenase), ao metabolismo de lipídeos (subunidade B da coenzima transferase succinil-CoA:3-cetoácido A), além de proteínas associadas com a formação ou reparo de DNA (subunidade A da DNA girase, subunidade alfa da ribonucleotídeo-difosfato redutase e proteína de reparo e emparelhamento de DNA) foram reprimidas (Figura 7). 
Figura 7 - Classificação funcional das CDS de $R$. rickettsii moduladas pelo aumento da temperatura de incubação de $25{ }^{\circ} \mathrm{C}$ para $35^{\circ} \mathrm{C}$ durante a infecção de fêmeas de $A$. aureolatum.

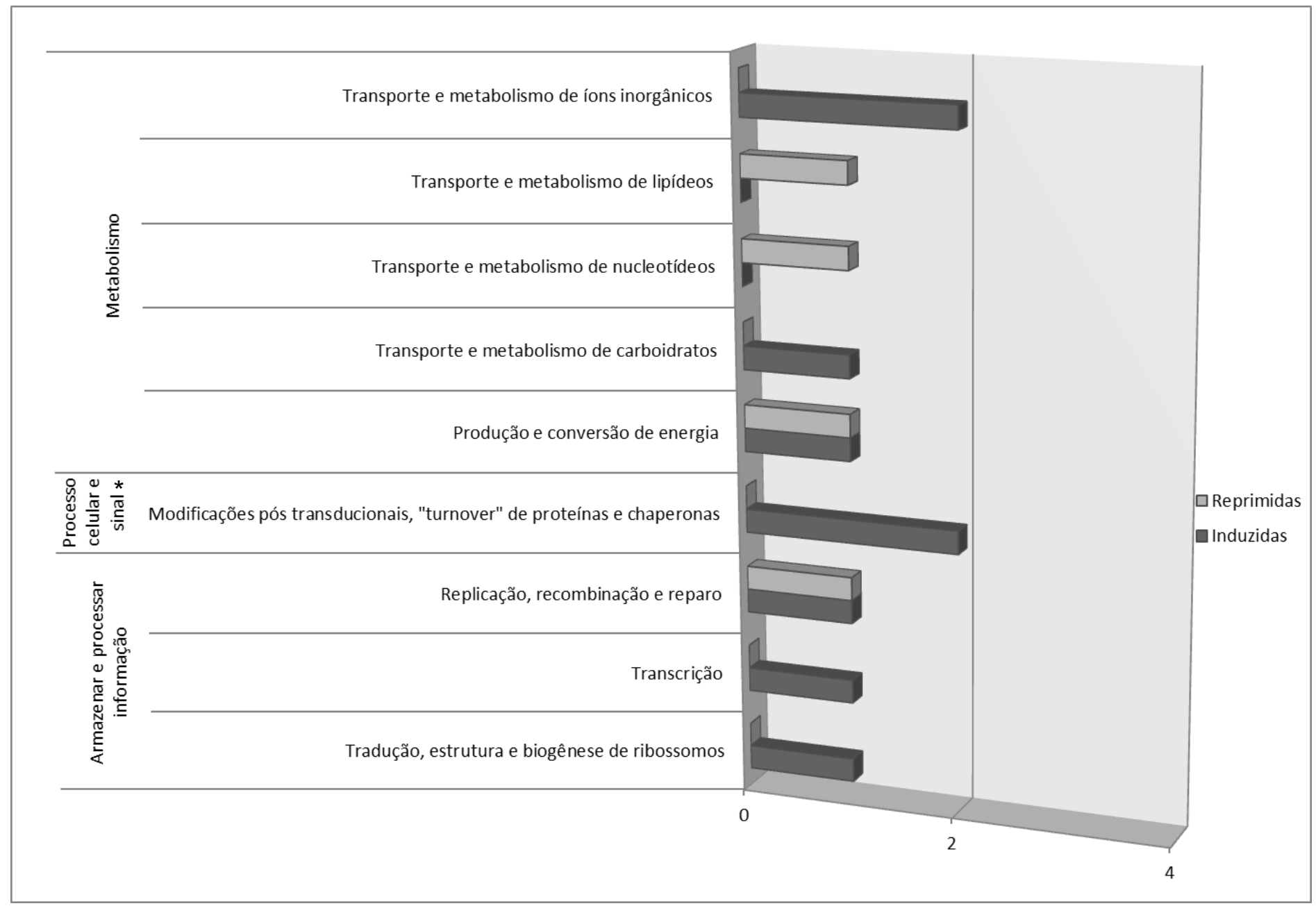

* Sinal: abreviação de sinalização. 
Tabela 2 - CDS de $R$. rickettsii com função anotada moduladas pela elevação da temperatura de incubação do carrapato vetor de $25^{\circ} \mathrm{C}$ para $35^{\circ} \mathrm{C}$.

\begin{tabular}{|c|c|c|c|c|c|}
\hline \multirow[b]{2}{*}{$\begin{array}{c}\text { Identificação } \\
\text { do gene }\end{array}$} & \multirow[b]{2}{*}{ CDS } & \multirow[b]{2}{*}{ Anotação } & \multirow[b]{2}{*}{ COG } & \multicolumn{2}{|c|}{ Fold-change } \\
\hline & & & & $\begin{array}{c}\text { Réplica } \\
\text { biológica } 1\end{array}$ & $\begin{array}{c}\text { Réplica } \\
\text { biológica } 2\end{array}$ \\
\hline A1G_00390 & ref|NC_009882.1_:c57026-55992 & Endonuclease putativa ligante de DNA/metaloproteína/AP & COG05330 & 1,98 & 1,72 \\
\hline A1G_00800 & ref|NC_009882.1_:132498-133136 & Proteína YsxC ligante de GTP & COG0218R & 1,87 & 1,61 \\
\hline A1G_02195 & ref|NC_009882.1_:c388225-387110 & Subunidade $\mathrm{D}$ putativa do antiporter de cátion $/ \mathrm{H}^{+}$monovalente & COG0651CP & 1,68 & 1,57 \\
\hline A1G_02785 & ref|NC_009882.1_:487702-488622 & Recombinase XerD tirosina sítio-específica & COG4974L & 1,53 & 1,53 \\
\hline A1G_05185 & ref|NC_009882.1_:c874676-873717 & Proteína CorA de transporte de magnésio e cobalto & COG0598P & 1,66 & 1,52 \\
\hline A1G_05370 & ref|NC_009882.1_:909316-909915 & Proteína GrpE & COG05760 & 1,62 & 1,80 \\
\hline A1G_05630 & ref|NC_009882.1_:c944176-943964 & Proteína de choque frio-like & COG1278K & 1,98 & 1,87 \\
\hline A1G_05635 & ref|NC_009882.1_:c946479-945574 & Dimetiladenosina transferase & COG0030J & 1,82 & 1,50 \\
\hline A1G_05960 & ref|NC_009882.1_:991314-992378 & Proteína de resistência a biciclomicina & COG2814G & 1,60 & 1,53 \\
\hline A1G_03490 & ref|NC_009882.1_:608404-609831 & Succinato semialdeído desidrogenase & COG1012C & $-1,79$ & $-1,59$ \\
\hline A1G_03670 & ref|NC_009882.1_:632043-633866 & Subunidade alfa da ribonucleotídeo-difosfato redutase & COG0209F & $-1,78$ & $-1,89$ \\
\hline A1G_03790 & ref|NC_009882.1_:652833-655895 & Antígeno de superfície & - & $-1,99$ & $-1,60$ \\
\hline A1G_05000 & ref|NC_009882.1_:844068-844703 & Subunidade $B$ da coenzima transferase succinil-CoA:3-cetoácido A & COG2057I & $-2,32$ & $-1,95$ \\
\hline A1G 07470 & ref|NC_009882.1_:c1249026-1247194 & Proteína de reparo e emparelhamento de DNA & COG0323L & $-1,69$ & $-1,54$ \\
\hline
\end{tabular}


4.2.3 Determinação dos efeitos da alimentação sobre o perfil de expressão gênica global de $R$. rickettsii

Duas amostras pool de RNA dos grupos G2 (fêmeas não alimentadas incubadas a $35^{\circ} \mathrm{C}$ por 3 dias) e G3 (fêmeas alimentadas em cães por 3 dias) foram obtidas. Cada amostra foi constituída pelo RNA extraído dos órgãos de sete fêmeas apresentando entre $1,60 \times 10^{8}$ e 2,20 × $10^{8}$ bactérias. Após a síntese e marcação do aRNA, as amostras foram hibridizadas com os microarranjos. Identificamos 221 CDS moduladas, as quais correspondem a cerca de $16 \%$ do total de CDS de $R$. rickettsii representadas nos microarranjos. Destas, 80 (36,20\%) foram induzidas e 141 $(63,80 \%)$ foram reprimidas, sendo que 119 (53,12\%) codificam proteínas com função anotada (Tabelas 3 e 4) e 105 (46,87\%) codificam proteínas hipotéticas (Apêndice D e E). Conforme descrito para a identificação de CDS de $R$. rickettsii moduladas pela elevação da temperatura, as CDS representadas pelos oligonucleotídeos que tiveram hibridização cruzada com o aRNA de carrapatos não infectados também foram excluídas das análises.

A aquisição da alimentação sanguínea pelo vetor induziu a transcrição de seis CDS ligadas à geração de energia (por exemplo, as subunidades G e C da proteína putativa de antiporter de cátion $/ \mathrm{H}^{+}$monovalente e as subunidade A e B da ATP sintase F0F1) (Figura 8). Ainda, CDS de enzimas envolvidas na cadeia de transporte de elétrons, tais como a subunidade $\mathrm{G}$ da NADH desidrogenase $\mathrm{e}$ polipeptídeos I e II da citocromo c oxidase, além da subunidade $\beta$ da $N A D(P)$ transidrogenase também foram induzidas pela alimentação sanguínea. Ademais, CDS de proteínas envolvidas nas funções de síntese e reparo de DNA também foram induzidas nesta condição, como mostrado pelo aumento de transcrição da subunidade alfa da DNA polimerase II, das exodesoxirribonucleases III e VII e das proteínas de reparo MutS, RecO e RecJ. Os eventos de tradução também se destacam nesta condição, já que ocorreu a indução das CDS da proteína ribossomal S8 da subunidade 30S das proteínas L18 e L28 da subunidade 50 S e do fator de iniciação da tradução (IF-3). Também se destaca a indução de CDS de proteínas relacionadas ao provável estresse oxidativo sofrido pela bactéria nos carrapatos alimentados, tais como a ferredoxina, a glutarredoxina 3 e a tiorredoxina peroxidase 1. Importantemente, a expressão de alguns fatores de virulência bacterianos também foi induzida pela alimentação sanguínea, dentre eles seis componentes do 
sistema de secreção do tipo IV (VirD4, VirB4, VirB8, VirB9, VirB10 e VirB11). O componente VirB3, por outro lado, foi reprimido pela aquisição de sangue. 
Figura 8 - Classificação funcional das CDS de $R$. rickettsii moduladas pela alimentação sanguínea de fêmeas de $A$. aureolatum infectadas.

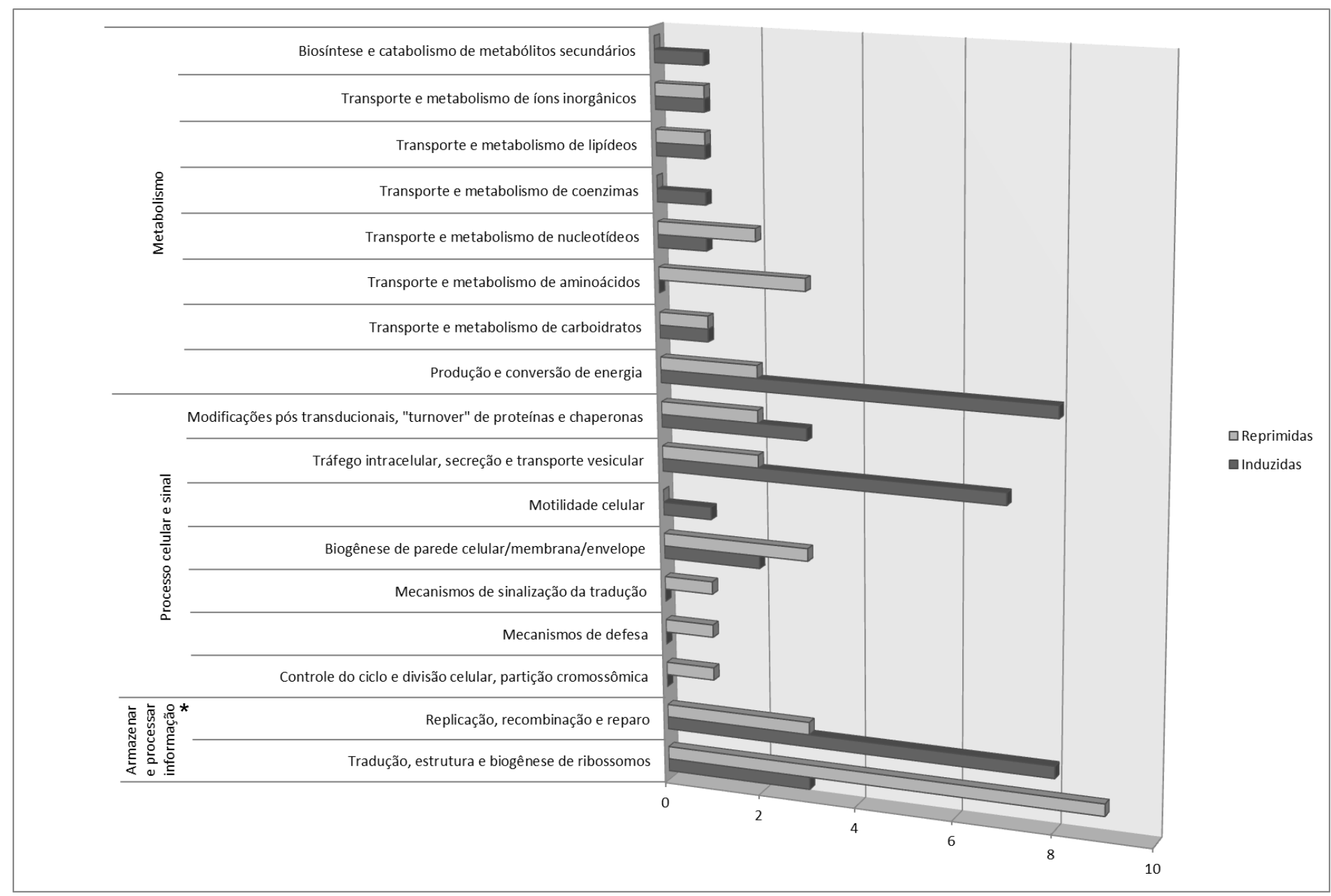

*Armazenar e processar informação: abreviação de armazenamento e processamento de informação. 
Tabela 3 - CDS de $R$. rickettsii com função anotada induzidas pela alimentação sanguínea do carrapato.

\begin{tabular}{|c|c|c|c|c|c|}
\hline \multirow[b]{2}{*}{$\begin{array}{l}\text { Identificação } \\
\text { do gene }\end{array}$} & \multirow[b]{2}{*}{ CDS } & \multirow[b]{2}{*}{ Anotação } & \multirow[b]{2}{*}{ COG } & \multicolumn{2}{|c|}{ Fold-change } \\
\hline & & & & $\begin{array}{c}\text { Réplica } \\
\text { biológica } 1\end{array}$ & $\begin{array}{c}\text { Réplica } \\
\text { biológica } 2\end{array}$ \\
\hline A1G_00160 & ref|NC_009882.1_:c29202-28708 & Subunidade B da ATP sintase FOF1 & COG0711C & 1,70 & 1,94 \\
\hline A1G_00175 & ref|NC_009882.1_:c30842-30114 & Subunidade A da ATP sintase FOF1 & COG0356C & 2,30 & 2,39 \\
\hline A1G_00430 & ref|NC_009882.1_:64387-64584 & Metilase de DNA sítio-específica & COG0270L & 1,78 & 2,08 \\
\hline A1G_00635 & ref|NC_009882.1_:c102248-100851 & Subunidade beta da NAD(p) transidrogenase & COG1282C & 1,89 & 1,80 \\
\hline A1G_00785 & ref|NC_009882.1_:c131143-131006 & Proteína L28 ribossomal (50S) & - & 1,77 & 1,77 \\
\hline A1G_01205 & ref|NC_009882.1_:225568-225900 & Proteína HU ligante de DNA & COG0776L & 3,09 & 3,48 \\
\hline A1G_01215 & ref|NC_009882.1_:227060-228409 & Proteína de reconhecimento de partículas & COG0541U & 1,64 & 1,62 \\
\hline A1G_01495 & ref|NC_009882.1_:c269892-269554 & Ferredoxina & COG0633C & 2,30 & 2,09 \\
\hline A1G_01525 & ref|NC_009882.1_:275087-275395 & Glutarredoxina 3 & COG06950 & 3,12 & 2,23 \\
\hline A1G_02025 & ref|NC_009882.1_:360525-360845 & Subunidade $\mathrm{G}$ do antiporter putativo de cation $/ \mathrm{H}^{+}$monovalente & COG1320P & 2,04 & 1,66 \\
\hline A1G_02035 & ref|NC_009882.1_:361975-362622 & Proteína B de transporte de heme & - & 1,53 & 1,76 \\
\hline A1G_02200 & ref|NC_009882.1_:c388743-388408 & Subunidade $\mathrm{C}$ do antiporter putativo de cation $/ \mathrm{H}^{+}$monovalente & COG1006P & 2,00 & 2,14 \\
\hline A1G_02205 & ref|NC_009882.1_:c389574-388822 & Proteína VirB9 & COG3504U & 2,42 & 2,35 \\
\hline A1G_02210 & ref|NC_009882.1_:c390274-389576 & Proteína VirB8 & COG3736U & 2,23 & 1,93 \\
\hline A1G_02230 & ref|NC_009882.1_:392342-393790 & Proteína VirB10 & COG2948U & 1,69 & 1,76 \\
\hline A1G_02235 & ref|NC_009882.1_:393787-394791 & ATPase VirB11 do Sistema de secreção do tipo IV & COG0630NU & 1,70 & 1,66 \\
\hline A1G_02240 & ref|NC_009882.1_:394925-396700 & Componente VirD4 do Sistema de secreção do tipo IV & COG3505U & 1,72 & 1,94 \\
\hline A1G_02290 & ref|NC_009882.1_:c406315-403655 & Proteína MutS de reparo e emparelhamento de DNA & COG0249L & 1,70 & 1,76 \\
\hline A1G_02555 & ref|NC_009882.1_:c450224-449622 & Tiorredoxina peroxidase 1 & COG0450O & 1,59 & 1,75 \\
\hline A1G_02595 & ref|NC_009882.1_:455319-456344 & Proteína capD & COG1086MG & 1,54 & 1,63 \\
\hline A1G_02600 & ref|NC_009882.1_:456337-457470 & Epimerase UDP-N-acetilglucosamina 2 putativa & COG0381M & 1,65 & 1,77 \\
\hline A1G_02690 & ref|NC_009882.1_:477545-477787 & Subunidade menor da exodesoxirribonuclease VII & COG1722L & 1,64 & 2,91 \\
\hline A1G_03140 & ref|NC_009882.1_:c552178-551231 & Polipeptídeo II da Citocromo C oxidase & COG1622C & 1,54 & 1,58 \\
\hline A1G_03350 & ref|NC_009882.1_:587602-588060 & Proteína ligante SsrA & COG06910 & 2,12 & 2,06 \\
\hline A1G_03685 & ref|NC_009882.1_:634696-635682 & Subunidade beta da redutase ribonucleotídeo-difosfato & COG0208F & 1,61 & 1,71 \\
\hline A1G_03930 & ref|NC_009882.1_:676576-677049 & Fator de iniciação da tradução IF-3 & COG0290J & 1,84 & 1,86 \\
\hline A1G_03935 & ref|NC_009882.1_:677195-678433 & Subunidade E2 da desidrogenase de alfa-cetoácido de cadeia ramificada & COG0508C & 1,52 & 1,54 \\
\hline A1G_03945 & ref|NC_009882.1_:679794-681557 & Exonuclease RecJ específica de fita única de DNA & COG0608L & 1,50 & 1,76 \\
\hline A1G_04575 & ref|NC_009882.1_:772880-773593 & Proteína de reparo de DNA RecO & COG1381L & 1,65 & 2,16 \\
\hline A1G_05475 & ref|NC_009882.1_:c923789-923442 & Proteína L18 ribossomal (50S) & COG0256J & 1,77 & 2,39 \\
\hline A1G_05485 & ref|NC_009882.1_:c924745-924347 & Proteína S8 ribossomal (30S) & COG0096J & 1,66 & 1,94 \\
\hline A1G_05670 & ref|NC_009882.1_:952076-952858 & Exodesoxirribonuclease III & COG0708L & 1,59 & 1,76 \\
\hline A1G_06385 & ref|NC_009882.1_:1054896-1055495 & Fosfatidilglicerofosfatase A & COG1267I & 2,16 & 1,75 \\
\hline A1G_06495 & ref|NC_009882.1_:1074289-1075014 & Proteína carreadora de acil (3-cetoacil redutase) & COG1028IQR & 1,57 & 1,54 \\
\hline A1G 06605 & ref|NC_009882.1:1093598-1093933 & Sintetase S-adenosilmetionina & COG0192H & 2,01 & 2,13 \\
\hline A1G_06640 & ref|NC_009882.1_:c1099203-1095658 & Subunidade alfa da DNA polimerase III & COG0587L & 1,73 & 1,73 \\
\hline A1G_06655 & ref|NC_009882.1_:1103534-1105075 & Proteína AmpG & - & 1,60 & 1,63 \\
\hline A1G_06670 & ref|NC_009882.1_:1107497-1109929 & Proteína precursora VirB4 & COG3451U & 2,10 & 2,08 \\
\hline A1G_06740 & ref|NC_009882.1_:c1127546-1125516 & Subunidade G da NADH desidrogenase & COG1034C & 1,67 & 1,66 \\
\hline A1G_06750 & ref|NC_009882.1_:c1130695-1128059 & Aconitase hidratase & COG1048C & 2,21 & 1,97 \\
\hline
\end{tabular}


Tabela 4 - CDS de $R$. rickettsii com função anotada reprimidas pela alimentação sanguínea do carrapato.

\begin{tabular}{|c|c|c|c|c|c|}
\hline \multirow{2}{*}{$\begin{array}{l}\text { Identificação } \\
\text { do gene }\end{array}$} & \multirow[b]{2}{*}{ CDS } & \multirow[b]{2}{*}{ Anotação } & \multirow[b]{2}{*}{ COG } & \multicolumn{2}{|c|}{ Fold-change } \\
\hline & & & & $\begin{array}{c}\text { Réplica } \\
\text { biológica } 1\end{array}$ & $\begin{array}{c}\text { Réplica } \\
\text { biológica } 2\end{array}$ \\
\hline A1G_00015 & ref|NC_009882.1_:1409-2158 & Proteína ligante de ATP RfbE do sistema de exportação do antígeno O & COG1134GM & $-1,76$ & $-1,63$ \\
\hline A1G_00025 & ref|NC_009882.1_:2932-6033 & Hidroxilase putativa bifuncional glutamato sintase, subunidade beta/2-poliprenilfenol & COG0493ER & $-1,60$ & $-1,54$ \\
\hline A1G_00080 & ref|NC_009882.1_:12813-13808 & Proteína NifR3-like & COG0042J & $-1,66$ & $-1,71$ \\
\hline A1G_00200 & ref|NC_009882.1_:34713-34922 & Fator de recombinação $\mathrm{F}$ & - & $-1,55$ & $-1,64$ \\
\hline A1G_00295 & ref|NC_009882.1_:45976-46317 & Antígeno-like de superfície Sca10 & - & $-2,39$ & $-2,27$ \\
\hline A1G_00390 & ref|NC_009882.1_:c57026-55992 & Endonuclease putativa ligante de DNA/ferro metaloproteína/AP & COG05330 & $-2,45$ & $-2,22$ \\
\hline A1G_00395 & ref|NC_009882.1_:c58403-57210 & Acil-CoA dessaturase 1 & COG1398I & $-2,13$ & $-1,64$ \\
\hline A1G_00515 & ref|NC_009882.1_:75811-77307 & Proteína carreadora de ADP,ATP & COG3202C & $-2,20$ & $-2,41$ \\
\hline A1G_00520 & ref|NC_009882.1_:77503-78798 & Transportador de glicerol-3-fosfato & COG2271G & $-1,62$ & $-1,83$ \\
\hline A1G_00525 & ref|NC_009882.1_:78823-79245 & Nucleosideo difosfato quinase & COG0105F & $-1,69$ & $-1,81$ \\
\hline A1G_00530 & ref|NC_009882.1_:79249-81117 & Enzima de modificação GidA tRNA uridine 5-carboximetilaminometil & COG0445D & $-2,04$ & $-1,81$ \\
\hline A1G_00575 & ref|NC_009882.1_:c88344-88012 & Proteína acessória de associação ferro-enxofre & COG0316S & $-2,58$ & $-2,68$ \\
\hline A1G_00680 & ref|NC_009882.1_:114829-115716 & Proteína S2 ribossomal (30S) & COG0052J & $-2,62$ & $-2,29$ \\
\hline A1G_00685 & ref|NC_009882.1_:115915-116844 & Fator de elongação Ts & COG0264J & $-1,79$ & $-1,78$ \\
\hline A1G_00800 & ref|NC_009882.1_:132498-133136 & Proteína YsxC ligante de GTP de biogênese de ribossomo & COG0218R & $-3,11$ & $-2,61$ \\
\hline A1G_00805 & ref|NC_009882.1_:133207-134007 & Acetilglutamato quinase & COG0548E & $-2,32$ & $-1,75$ \\
\hline A1G_00810 & ref|NC_009882.1_:134020-134307 & Proteína VirB3 do sistema de secreção tipo IV & COG3702U & $-2,07$ & $-1,89$ \\
\hline A1G_00880 & ref|NC_009882.1_:155386-155802 & Proteína L19 ribossomal (50S) & COG0335J & $-2,44$ & $-1,88$ \\
\hline A1G_00920 & ref|NC_009882.1_:161909-162601 & tRNA/rRNA metiltransferase & COG0565J & $-1,95$ & $-1,79$ \\
\hline A1G_00945 & ref|NC_009882.1_:165322-166362 & Modulador da atividade de protease HfIK & COG03300 & $-1,58$ & $-1,60$ \\
\hline A1G_01390 & ref|NC_009882.1_:256639-257463 & 2,3,4,5-tetraidropiridina-2,6-carboxilato $\mathrm{N}$-succiniltransferase & COG2171E & $-1,71$ & $-1,56$ \\
\hline A1G_01440 & ref|NC_009882.1_:266435-266578 & Antígeno-like de superfície Sca8 & - & $-5,66$ & $-5,15$ \\
\hline A1G_01445 & ref|NC_009882.1_:262509-262940 & Antígeno-like de superfície Sca8 & - & $-4,06$ & $-3,50$ \\
\hline A1G_01475 & ref|NC_009882.1_:263261-263530 & Antígeno-like de superfície Sca8 & - & $-6,15$ & $-7,11$ \\
\hline A1G_01595 & ref|NC_009882.1_:283754-284281 & Peptídeo deformilase & COG0242J & $-2,32$ & $-1,94$ \\
\hline A1G_01600 & ref|NC_009882.1_:284293-285189 & Formiltransferase metionil-tRNA & COG0223J & $-1,93$ & $-2,00$ \\
\hline A1G_01640 & ref|NC_009882.1_:c295786-294017 & Ligante de ATP do transportador $\mathrm{ABC}$ resistente a multidrogas & COG1132V & $-1,64$ & $-1,65$ \\
\hline A1G_01670 & ref|NC_009882.1_:299495-300343 & Beta 1,4-glicosiltransferase & COG0463M & $-3,08$ & $-2,15$ \\
\hline A1G_01675 & ref|NC_009882.1_:300420-301658 & Protease mitocondrial & COG0612R & $-2,34$ & $-1,83$ \\
\hline A1G_01680 & ref|NC_009882.1_:301812-302522 & Fosforribosilaminoimidazol-succinocarboxamida sintetase & COG0152F & $-1,93$ & $-1,62$ \\
\hline A1G_01995 & ref||NC_009882.1_:c357123-355294 & Proteína ligante de GTP & COG1217T & $-2,23$ & $-2,16$ \\
\hline A1G_02095 & ref|NC_009882.1_:c370213-369356 & Fator 2 de relaxamento de cadeia peptídica & COG1186J & $-1,57$ & $-1,76$ \\
\hline A1G_02170 & ref|NC_009882.1_:c384629-383091 & Subunidade D putativa de antiporter de cation $/ \mathrm{H}^{+}$monovalente & COG0651CP & $-1,63$ & $-2,04$ \\
\hline A1G_02680 & ref|NC_009882.1_:c474839-474342 & Proteína RimM de processamento de rRNA16S & COG0806J & $-2,18$ & $-1,93$ \\
\hline A1G_02785 & ref|NC_009882.1_:487702-488622 & Recombinase XerD tirosina sítio-específica & COG4974L & $-2,52$ & $-2,87$ \\
\hline A1G_02825 & ref|NC_009882.1_:496734-497573 & Permease de transportador $\mathrm{ABC}$ & COG4120R & $-1,84$ & $-1,95$ \\
\hline A1G_02830 & ref|NC_009882.1_:497570-498292 & Ligante putativo de ATP do transportador ABC & COG1101R & $-1,79$ & $-2,34$ \\
\hline A1G_03010 & ref|NC_009882.1_:525371-525985 & DNA helicase RuvA - Holliday junction & COG0632L & $-3,83$ & $-3,52$ \\
\hline A1G_03025 & ref|NC_009882.1_:526978-528006 & DNA helicase RuvB - Holliday junction & COG2255L & $-1,53$ & $-1,63$ \\
\hline A1G_03150 & ref|NC_009882.1:554615-555154 & Peptidase sinal de lipoproteína & COG0597MU & $-2,65$ & $-2,19$ \\
\hline
\end{tabular}


Tabela 4 (Continuação).

\begin{tabular}{|c|c|c|c|c|c|}
\hline \multirow[b]{2}{*}{$\begin{array}{l}\text { Identificação } \\
\text { do gene }\end{array}$} & \multirow[b]{2}{*}{ CDS } & \multirow[b]{2}{*}{ Anotação } & \multirow[b]{2}{*}{ COG } & \multicolumn{2}{|c|}{ Fold-change } \\
\hline & & & & $\begin{array}{c}\text { Réplica } \\
\text { biológica } 1\end{array}$ & $\begin{array}{c}\text { Réplica } \\
\text { biológica } 2\end{array}$ \\
\hline A1G_03160 & ref|NC_009882.1_:555741-557243 & UDP-N-acetilmuramoil-L-alanil-D-glutamato sintetase & COG0771M & $-1,88$ & $-1,66$ \\
\hline A1G_03165 & ref|NC_009882.1_:557375-558508 & Proteína de divisão celular FtsW & COG0772D & $-2,31$ & $-2,00$ \\
\hline A1G_03170 & ref|NC_009882.1_:558505-559635 & Undecaprenildifosfo-muramoilpentapeptideo beta- $\mathrm{N}$ - acetilglucosaminiltransferase & COG0707M & $-1,65$ & $-1,54$ \\
\hline A1G_03250 & ref|NC_009882.1_:c568298-567279 & Proteína CapM & COG0438M & $-3,43$ & $-2,99$ \\
\hline A1G_03280 & ref|NC_009882.1_:571571-572620 & Subunidade alfa da fenilalanil-tRNA sintetase & COG0016J & $-1,52$ & $-1,50$ \\
\hline A1G_03780 & ref|NC_009882.1_:651005-652540 & tRNA pseudouridina sintase B & COG0130J & $-1,90$ & $-1,96$ \\
\hline A1G_04070 & ref|NC_009882.1_:c698126-696873 & Proteína ampG & COG2271G & $-2,05$ & $-1,66$ \\
\hline A1G_04075 & ref|NC_009882.1_:c698615-698370 & Transposase & - & $-2,44$ & $-2,34$ \\
\hline A1G_04275 & ref|NC_009882.1_:c729262-728207 & Porfobilinogênio desaminase & COG0181H & $-4,57$ & $-6,30$ \\
\hline A1G_04285 & ref|NC_009882.1_:c730629-730501 & Histidina quinase de simporte de $\mathrm{Na}+$ /prolina e tradução de sinais & - & $-6,29$ & $-5,12$ \\
\hline A1G_04290 & ref|NC_009882.1_:c731081-730683 & Histidina quinase sensor de 2-componentes & COG2205T & $-6,91$ & $-5,17$ \\
\hline A1G_04835 & ref|NC_009882.1_:c813871-813740 & Subunidade R (restriction) do tipo 1 sítio- específica do sistema de modificação e restrição & - & $-2,28$ & $-1,84$ \\
\hline A1G_05020 & ref|NC_009882.1_:845765-845917 & Fosfo-N-acetilmuramoil-pentapeptideo-transferase & - & $-2,09$ & $-2,68$ \\
\hline A1G_05095 & ref|NC_009882.1_:991314-992378 & Proteína de resistência a biciclomicina & - & $-4,62$ & $-3,16$ \\
\hline A1G_05210 & ref|NC_009882.1_:c881085-879286 & Proteína reguladora de nitrogênio NtrY & COG5000T & $-2,10$ & $-2,52$ \\
\hline A1G_05315 & ref|NC_009882.1_:C901984-901727 & Chaperonina GroEL & - & $-1,53$ & $-1,88$ \\
\hline A1G_05620 & ref|NC_009882.1_:c941865-940801 & Proteína ampG & - & $-2,43$ & $-1,96$ \\
\hline A1G_05625 & ref|NC_009882.1_:c943449-942217 & RNA helicase RhIE ATP-dependente & COG0513LKJ & $-2,98$ & $-2,49$ \\
\hline A1G_05635 & ref|NC_009882.1_:c946479-945574 & Dimetiladenosina transferase & COG0030J & $-3,61$ & $-2,68$ \\
\hline A1G_05925 & ref|NC_009882.1_:c985898-984621 & Subunidade ClpX ligante de ATP da protease ATP-dependente & COG12190 & $-1,87$ & $-1,62$ \\
\hline A1G_05935 & ref|NC_009882.1_:C987336-986650 & Proteína trans-regulatória ExsB & COG0603R & $-2,76$ & $-3,02$ \\
\hline A1G_05960 & ref|NC_009882.1_:c862507-862325 & Proteína de resistência a biciclomicina & COG2814G & $-1,87$ & $-1,58$ \\
\hline A1G_06065 & ref|NC_009882.1_:c1013060-1012188 & Lauril aciltransferase lipídeo A & COG1560M & $-2,51$ & $-2,19$ \\
\hline A1G_06070 & ref|NC_009882.1_:c1014000-1013035 & Tetraacildissacarídeo 4'-quinase & COG1663M & $-3,18$ & $-2,98$ \\
\hline A1G_06075 & ref|NC_009882.1_:c1014858-1014004 & Proteína periplasmática putativa & COG0739M & $-3,36$ & $-4,04$ \\
\hline A1G_06135 & ref|NC_009882.1_:c1024825-1024376 & Proteína ligante de substrato de transportador $A B C$ & COG1463Q & $-1,70$ & $-1,56$ \\
\hline A1G_06145 & ref|NC_009882.1_:c1025600-1025133 & Ribonuclease H & COG0328L & $-2,08$ & $-1,82$ \\
\hline A1G_06170 & ref|NC_009882.1_:1029038-1029760 & Proteína surfeit, locus 1 & COG3346S & $-2,18$ & $-2,05$ \\
\hline A1G_06265 & ref|NC_009882.1_:1040765-1042162 & Proteína carreadora de ADP,ATP & COG3202C & $-1,91$ & $-2,02$ \\
\hline A1G_06400 & ref|NC_009882.1_:1056470-1057675 & Aspartato quinase & COG0527E & $-1,87$ & $-1,77$ \\
\hline A1G_06435 & ref|NC_009882.1_:c1061573-1060332 & Transportador prolina/betaína & - & $-3,11$ & $-2,65$ \\
\hline A1G_06705 & ref|NC_009882.1_:1117766-1118383 & NADH desidrogenase subunidade $J$ & COG0839C & $-2,11$ & $-1,93$ \\
\hline A1G_06710 & ref|NC_009882.1_:1118376-1118690 & NADH desidrogenase subunidade $\mathrm{K}$ & COG0713C & $-4,59$ & $-3,56$ \\
\hline A1G_06715 & ref|NC_009882.1_:1118690-1120663 & NADH desidrogenase subunidade $L$ & COG1009CP & $-1,97$ & $-1,54$ \\
\hline A1G_07355 & ref|NC_009882.1_:c1234383-1234144 & Antitoxina do sistema de toxina-antitoxina StbD & COG2161D & $-3,32$ & $-2,82$ \\
\hline A1G_07375 & ref|NC_009882.1_:1236834-1237097 & Proteína J induzida por danos ao DNA & COG3077L & $-1,98$ & $-1,82$ \\
\hline A1G_07380 & ref|NC_009882.1_:1237189-1237332 & Toxina do sistema de toxina-antitoxina da família de proteínas RelE/StbE & COG3041S & $-3,13$ & $-2,62$ \\
\hline A1G 07400 & ref|NC_009882.1:c1240365-1239220 & Succinil-diaminopimelato desuccinilase & COG0624E & $-2,61$ & $-2,18$ \\
\hline
\end{tabular}




\subsection{Caracterização in silico das proteínas hipotéticas moduladas pela temperatura e alimentação sanguínea}

Dentre as CDS de $R$. rickettsii moduladas pela elevação da temperatura e pela alimentação sanguínea em carrapatos, identificadas pelos experimentos de microarranjos, 133 (56\%) codificam proteínas hipotéticas. Interessantemente, muitas CDS de proteínas hipotéticas apresentaram valores de fold-change bastante superiores aos de CDS de proteínas com função anotada. A fim de obtermos mais informações acerca dessas CDS, realizamos uma análise in silico de similaridade com domínios característicos de proteínas eucarióticas e procarióticas presentes no banco de dados público Conserved Domain Database (CDD). Das CDS analisadas que foram moduladas pela elevação da temperatura, 17 apresentaram similaridade com proteínas previamente anotadas (e-values entre 2.99e-03 e 2.16e-50) (Tabela 5). Treze CDS diferencialmente expressas pela temperatura não exibiram nenhuma similaridade com proteínas dos bancos de dados. Das 103 CDS de proteínas hipotéticas moduladas pela alimentação sanguínea, 72 apresentaram similaridades com proteínas do banco de dados (e-values entre 2.90e-03 e 3.00e-116) (Tabelas 6 e 7) e 31 CDS não exibiram nenhuma identidade com estruturas previamente descritas. 
Tabela 5 - Análise de similaridade de proteínas hipotéticas moduladas pelo aumento de temperatura de incubação de $25^{\circ} \mathrm{C}$ para $35^{\circ} \mathrm{C}$.

\begin{tabular}{|c|c|c|c|c|}
\hline CDS & Anotação & $\begin{array}{l}\text { Média do fold-change } \\
\text { (réplicas biológicas } 1 ; 2 \text { ) }\end{array}$ & Busca de domínios - CDD & E-Value \\
\hline \multicolumn{5}{|c|}{ Reprimidas pela elevação de temperatura } \\
\hline ref|NC_009882.1_:489832-490995 & Proteína hipotética A1G_02795 & $1,99(2,07 ; 1,92)$ & Lipoproteína_7[pfam01540] - Lipoproteína adesina & $2.65 \mathrm{e}-03$ \\
\hline ref|NC_009882.1:520257-521780 & Proteína hipotética A1G 02985 & $2,25(2,50 ; 1,99)$ & Heme Cu Oxidase I super família[cl00275] - Subunidade I da heme-cobre oxidade & $6.66 \mathrm{e}-18$ \\
\hline ref|NC_009882.1_:691150-691590 & Proteína hipotética A1G_04030 & $2,07(2,31 ; 1,84)$ & COG5622[COG5622] - Proteína requerida para ligação à células do hospedeiro & $4.84 \mathrm{e}-61$ \\
\hline ref|NC_009882.1_:c871627-869777 & Proteína hipotética A1G_05165 & $2,92(2,90 ; 2,95)$ & ANK[cd00204] - repetições de ankirina & $4.60 \mathrm{e}-03$ \\
\hline ref|NC_009882.1_:1020437-1020736 & Proteína hipotética A1G_06100 & $2,26(2,96 ; 1,56)$ & SpoT[COG0317] - Pirofosfohidrolase/sintetase guanosina pilofosfato & $2.71 \mathrm{e}-16$ \\
\hline ref|NC $009882.1: 1250262-1250714$ & Proteína hipotética A1G 07480 & $2,62(3,02 ; 2,21)$ & SNF2 assoc super familia [cl07173] - Helicase SNF2 bacteriana & $9.57 \mathrm{e}-03$ \\
\hline \multicolumn{5}{|c|}{ Induzidas pela elevação de temperatura } \\
\hline ref|NC 009882.1:c346202-345054 & Proteína hipotética A1G 01945 & $2,19(2,26 ; 2,12)$ & Super família AgrB [cl01873] - Gene acessório regulador B & $8.85 \mathrm{e}-04$ \\
\hline ref|NC_009882.1_:524000-524968 & Proteína hipotética A1G_03000 & $2,92(3,46 ; 2,38)$ & Família Fic/DOC de filamentação induzida por cAMP & $2.07 \mathrm{e}-22$ \\
\hline ref|NC $009882.1: c 535744-534896$ & Proteína hipotética A1G 03065 & $1,80(1,99 ; 1,61)$ & FTR1[pfam03239] - Família FTR1 da ferro permease & $9.12 \mathrm{e}-60$ \\
\hline ref|NC_009882.1_:787589-787804 & Proteína hipotética A1G_04655 & $1,89(1,84 ; 1,94)$ & Transposase_20[pfam02371] - Família IS116/IS110/IS902 de transposase & $6.69 \mathrm{e}-08$ \\
\hline reffNC_009882.1_:c947519-946632 & Proteína hipotética A1G_05640 & $2,04(2,23 ; 1,85)$ & SurA_N_3 super família [cl07813] - Domínio N-terminal da chaperona SurA & $2.06 \mathrm{e}-12$ \\
\hline refiNC 009882.1: c1226140-1225526 & Proteína hipotética A1G 07280 & $1,70(1,72 ; 1,69)$ & MFS[cd06174] - Principal facilitador da superfamília de transporters secundários & $8.65 \mathrm{e}-04$ \\
\hline
\end{tabular}


Tabela 6 - Análise de similaridade de proteínas hipotéticas induzidas pela alimentação sanguínea.

\begin{tabular}{|c|c|c|c|c|}
\hline CDS & Anotação & $\begin{array}{l}\text { Média do fold change } \\
\text { (réplicas biológicas } 1 ; 2 \text { ) }\end{array}$ & Busca de domínios - CDD & E-Value \\
\hline \multicolumn{5}{|l|}{ Induzidas pela alimentação sanguínea } \\
\hline ref|NC_009882.1_:c32054-31221 & Proteína hipotética A1G_00185 & $2,02(2,13 ; 1,92)$ & pfam13462 - Tiorredoxina & $9.74 \mathrm{e}-56$ \\
\hline ref|NC_009882.1_c43779-43210 & Proteína hipotética A1G 00270 & $1,70(1,54 ; 1,85)$ & COG1678 - Fator transcricional putativo & $2.36 \mathrm{e}-80$ \\
\hline ref|NC_009882.1_:c58861-58682 & Proteína hipotética A1G_00400 & $1,87(1,84 ; 1,90)$ & Super familia HTH [cl00088] - Domínio Helix-turn-helix & $5.69 \mathrm{e}-09$ \\
\hline ref|NC_009882.1_:C96803-95487 & Proteína hipotética A1G_00605 & $2,69(2,76 ; 2,62)$ & Porina_4[pfam13609], Porina Gram negativa & $3.11 \mathrm{e}-17$ \\
\hline ref|NC_009882.1_: c103121-102387 & Proteína hipotética A1G 00640 & $1,83(1,84 ; 1,81)$ & OmpW[COG3047], Proteína W da membrana externa & $1.89 \mathrm{e}-48$ \\
\hline ref|NC_009882.1_:c122272-122108 & Proteína hipotética A1G_00715 & $2,09(1,88 ; 2,30)$ & PhdYeFM_antitox[pfam02604], Antitoxina Phd_YefM do sistema tipo II da toxina antitoxina & $1.12 \mathrm{e}-14$ \\
\hline ref|NC_009882.1_:122409-123413 & Proteína hipotética A1G 00720 & $1,80(1,53 ; 2,07)$ & TPR[cd00189] - Dominio do reapeat tetratricopeptídeo & $1.58 \mathrm{e}-06$ \\
\hline ref|NC_009882.1_:c191555-190416 & Proteína hipotética A1G_01045 & $1,99(1,83 ; 2,15)$ & RPE1[TIGR01045] - Elemento palindrômico de Rickettsia - domínio RPE1 & $1.61 \mathrm{e}-18$ \\
\hline ref|NC_009882.1_:c245095-244994 & Proteína hipotética A1G 01325 & $1,99(1,99 ; 1,99)$ & ChaB super familia [cl01887] -ChaB & $4.71 \mathrm{e}-12$ \\
\hline ref|NC $009882.1: 255227-255586$ & Proteína hipotética A1G 01380 & $2,71(2,69 ; 2,73)$ & VirB2[COG3838] - Componente VirB2 do Sistema de secreção tipo IV & $2.17 \mathrm{e}-21$ \\
\hline ref|NC_009882.1_:c268466-267525 & Proteína hipotética A1G_01485 & $1,61(1,56 ; 1,66)$ & Imp[COG2358] - Componente periplasmático TRAP-type não caracterizado de sistema de transporte & $1.77 \mathrm{e}-111$ \\
\hline ref|NC_009882.1_:c269541-268471 & Proteína hipotética A1G_01490 & $2,14(2,16 ; 2,12)$ & MopB_Res-Cmplx1_Nad11-M [cd02774] - NADH Oxiredutase mitocondrial codificada & $9.49 \mathrm{e}-05$ \\
\hline ref|NC_009882.1_:283121-283303 & Proteína hipotética A1G_01585 & $1,87(1,83 ; 1,91)$ & HIG_1_N[pfam04588] - Região conservada da proteína induzida por hipóxia & $2.52 \mathrm{e}-06$ \\
\hline ref|NC_009882.1_:436964-437104 & Proteína hipotética A1G_02475 & $1,61(1,50 ; 1,72)$ & PDDEXK_2 super familia [Cl15088] - Transposase PD-(D/E)XK & $8.12 \mathrm{e}-06$ \\
\hline ref|NC_009882.1_:c551038-550655 & Proteína hipotética A1G_03135 & $1,70(1,68 ; 1,72)$ & LbH XAT[cd03349] - Aciltransferase xenobiotico & $1.25 \mathrm{e}-09$ \\
\hline ref|NC_009882.1_:609991-610131 & Proteína hipotética A1G_03495 & $2,31(1,91 ; 2,71)$ & COG3956[COG3956] - Proteína com domínio tetrapirrolmetiltransferase & $4.87 \mathrm{e}-03$ \\
\hline ref|NC_009882.1_:782754-783182 & Proteína hipotética A1G_04620 & $1,91(2,12 ; 1,70)$ & Super familia HTH [cl00088] - Domínio Helix-turn-helix & $4.82 \mathrm{e}-39$ \\
\hline ref|NC_009882.1_:c790607-790365 & Proteína hipotética A1G_04690 & $1,94(1,88 ; 2,01)$ & Super família Flu_M2 [cl02903] - Proteína de matriz de Influenza (M2) & $2.90 \mathrm{e}-03$ \\
\hline ref|NC_009882.1_c913327-913094 & Proteína hipotética A1G 05400 & $2,13(1,90 ; 2,36)$ & GAS[pfam13851] - Ligante específico de microtúbulo & $4.10 \mathrm{e}-03$ \\
\hline ref|NC_009882.1_:994684-996585 & Proteína hipotética A1G_05975 & $1,78(1,61 ; 1,95)$ & ULP1[COG5160] - Protease - familia Ulp1 & $4.27 \mathrm{e}-04$ \\
\hline ref|NC_009882.1_:1051294-1051470 & Proteína hipotética A1G_06350 & $3,57(4,12 ; 3,01)$ & COG5510[COG5510] - Pequena proteína secretada & $4.88 \mathrm{e}-15$ \\
\hline ref|NC_009882.1_:c1062928-1062575 & Proteína hipotética A1G_06455 & $1,83(2,06 ; 1,61)$ & HTH_25[pfam13413] - Domínio Helix-turn-helix & $1.10 \mathrm{e}-20$ \\
\hline ref|NC_009882.1_:c1071820-1071686 & Proteína hipotética A1G_06480 & $1,98(1,88 ; 2,08)$ & PRK14995[PRK14995] - Proteína metil SmvA viologen de resistência & $4.84 \mathrm{e}-04$ \\
\hline ref/NC_009882.1_:1100886-1103396 & Proteína hipotética A1G 06650 & $1,90(1,75 ; 2,04)$ & AsmA 2[pfam 13502] - região C-terminal AsmA-like & $2.31 \mathrm{e}-07$ \\
\hline ref|NC_009882.1_:c1127890-1127534 & Proteína hipotética A1G_06745 & $2,82(2,94 ; 2,69)$ & COG3671[COG3671] - Proteína predita de membrana & $3.91 \mathrm{e}-67$ \\
\hline ref|NC_009882.1_: c1233873-1233787 & Proteína hipotética A1G 07345 & $2,03(1,96 ; 2,10)$ & Super família transpeptidase [cl01009] - Domínio transpeptidase da proteína ligante de penicilina & $1.05 \mathrm{e}-05$ \\
\hline ref|NC_009882.1_:1250262-1250714 & Proteína hipotética A1G 07480 & $2,51(2,41 ; 2,62)$ & SNF2_assoc super família [cl07173] - Helicase bacteriana SNF2 associado & $9.57 \mathrm{e}-03$ \\
\hline
\end{tabular}


Tabela 7 - Análise de similaridade de proteínas hipotéticas reprimidas pela alimentação sanguínea.

\begin{tabular}{|c|c|c|c|c|}
\hline $\operatorname{cDS}$ & Anotação & $\begin{array}{l}\text { Média do fold change } \\
\text { (réplicas biológicas 1;2) }\end{array}$ & Busca de domínios - CDD & E-Value \\
\hline \multicolumn{5}{|l|}{ Reprimidas pela alimentação sanguínea } \\
\hline ref|NC_009882.1_:c6316-6077 & Proteína hipotética A1G_00030 & $-2,28(2,39 ; 2,17)$ & MazF[COG2337] - Inibidor de crescimento & $4.40 \mathrm{e}-15$ \\
\hline ref|NC_009882.1_:13826-14749 & Proteína hipotética A1G_00085 & $-1,83(1,98 ; 1,68)$ & CE4_RC0012_like[cd10963] - Domínio homólogo à NodB catalítica putativa de Rickettsia conorii e bactérias homólogas & $8.64 \mathrm{e}-114$ \\
\hline ref|NC_009882.1_:32218-32739 & Proteína hipotética A1G_00190 & $-2,74(2,88 ; 2,59)$ & COG1329[COG1329] - Reguladores de transcrição, similar a CarD do Myxococcus xanthus & $2.39 \mathrm{e}-72$ \\
\hline ref|NC_009882.1_:137058-140018 & Proteína hipotética A1G_00820 & $-1,83(1,88 ; 1,78)$ & VirB6[COG3704] Componente VirB6 do Sistema de secreção tipo IV & $3.76 \mathrm{e}-101$ \\
\hline ref|NC_009882.1_:140005-141990 & Proteína hipotética A1G_00825 & $-1,68(1,77 ; 1,59)$ & VirB6[COG3704] - Componente VirB6 do Sistema de secreção tipo IV & $9.75 \mathrm{e}-103$ \\
\hline refiNC_009882.1_c199098-196984 & Proteína hipotética A1G_01070 & $-1,67(1,65 ; 1,69)$ & poIC[PRK00448], DNA polimerase III PoIC validada & $5.33 \mathrm{e}-03$ \\
\hline refiNC_009882.1_:210439-210642 & Proteína hipotética A1G_01135 & $-1,93(1,96 ; 1,89)$ & DUF2674[pfam 10879] - Proténa de função desconhecida (DUF2674) conservada em Rickettsia spp & $2.24 \mathrm{e}-46$ \\
\hline ref|NC_009882.1_:C346202-345054 & Proteína hipotética A1G_01945 & $-1,70(1,87 ; 1,52)$ & Super família AgrB [c101873] - Gene acessório regulador B & $8.85 \mathrm{e}-04$ \\
\hline ref|NC_009882.1_:384409-384507 & Proteína hipotética A1G_02175 & $-2,62(2,47 ; 2,76)$ & PRK06588[PRK06588] - Subunidade D do putativo antiporter monovalente cation $/ \mathrm{H}_{+}$ & $3.48 \mathrm{e}-23$ \\
\hline ref|NC_009882.1_:c413519-412539 & Proteína hipotética A1G_02330 & $-2,87(2,91 ; 2,84)$ & Super familia Nucleotid_trans [c105288] - Nucleotide-difosfo-açúcar transferase & $7.40 \mathrm{e}-04$ \\
\hline ref|NC_009882.1_c439531-439259 & Proténa hipotética A1G_02495 & $-2,08(2,35 ; 1,81)$ & $\begin{array}{l}\text { flgK_ends[TIGR02492] - Proteína flagelar FlgK } \\
\text { flu- }\end{array}$ & $9.61 \mathrm{e}-03$ \\
\hline refiNC_009882.1_:C462530-461532 & Proteína hipotética A1G_02620 & $-1,71(1,75 ; 1,67)$ & AcrA[COG0845] - Proteína de fusão à membrana & $1.20 \mathrm{e}-31$ \\
\hline ref|NC_009882.1_:495812-496729 & Proteína hipotética A1G_02820 & $-1,80(1,66 ; 1,84)$ & COG2984[COG2984] - Componente periplasmático do sistema de transporte tipo ABC não caracterizado & $1.35 \mathrm{e}-97$ \\
\hline ref|NC_009882.1_:c499229-498807 & Proteína hipotética A1G 02840 & $-3,03(3,30 ; 2,77)$ & ANK[cd00204] - repetiçōes de ankirina & $1.50 \mathrm{e}-08$ \\
\hline reffNC_009882.1_:524000-524968 & Proteína hipotética A1G_03000 & $-7,20(8,32 ; 6,07)$ & Fic[pfam02661] - Familia Fic/DOC de processos de filamentos induzidas por cAMP & $2.07 \mathrm{e}-22$ \\
\hline ref|NC_009882.1_c533894-533406 & Proténa hipotética A1G_03050 & $-2,67(3,04 ; 2,31)$ & BON[pfam04972] - Domínio BON encontrado em uma família de proteínas de proteção ao choque térmico & $3.58 \mathrm{e}-13$ \\
\hline reffNC_009882.1_c535744-534896 & Proteína hipotética A1G_03065 & $-2,43(2,81 ; 2,05)$ & Familía FTR1[pfam03239] - Ferro permease, familia FTR1 & $9.12 \mathrm{e}-60$ \\
\hline ref|NC_009882.1_:c536134-535754 & Proteína hipotética A1G_03070 & $-1,97(2,20 ; 1,73)$ & Cupredoxina_1[pfam13473] - Domínio cupredoxina-like & $5.13 e-37$ \\
\hline ref|NC_009882.1_c537320-536325 & Proteína hipotética A1G_03075 & $-3,04(3,65 ; 2,43)$ & FKBP_C[pfam00254] - Isomerase tipo FKBP peptidil-prolil cis-trans & $4.61 \mathrm{e}-07$ \\
\hline ref|NC_009882.1_:c727231-727037 & Proteína hipotética A1G_04255 & $-2,84(3,02 ; 2,67)$ & DUF4143[pfam13635] - Domínio de função desconhecida (DUF4143) encontrada na família ATPase & $1.37 \mathrm{e}-06$ \\
\hline ref|NC_009882.1_c727818-727639 & Proténa hipotética A1G_04270 & $-6,59(6,03 ; 7,16)$ & Super familia [P-loop_NTPasecl09099] - Hidrolase nucleotídica trifosfato & $6.62 \mathrm{e}-03$ \\
\hline refiNC_009882.1_cic730245-729259 & Proteína hipotética A1G_04280 & $-7,35(7,85 ; 6,86)$ & Peptidase_S66[cd07025] - LD-Carboxipeptidase, uma serino protease & $9.72 \mathrm{e}-51$ \\
\hline refi|NC_009882.1_: c733692-733087 & Proténa hipotética A1G_04305 & $-4,36(4,91,3,82)$ & ANK[cd00204] - repetiçôes de ankirina & $6.67 \mathrm{e}-06$ \\
\hline reffNC $009882.1 \div 767346-770225$ & Proteína hipotética A1G 04555 & $-1,68(1,66 ; 1,72)$ & Pentapeptide[pfam 00805] - Repetiçōes de pentapeptídeos (8 cópias) encontrado em proteínas cianobactérias & $1.99 \mathrm{e}-06$ \\
\hline ref|NC_009882.1_:774111-774803 & Proteína hipotética A1G_04585 & $-3,32(3,52 ; 3,13)$ & COG1214[COG1214] - Homólogo inativo da protease dependente de metal, chaperona molecular putativa & $5.47 \mathrm{e}-58$ \\
\hline ref|NC_009882.1_:c868072-867395 & Proténa hipotética A1G_05140 & $-2,28(2,16 ; 2,39)$ & Radical_SAM[cd01335] - Super família Radical SAM & $8.62 \mathrm{e}-06$ \\
\hline ref|NC_009882.1_:c947519-946632 & Proteína hipotética A1G_05640 & $-2,10(2,38 ; 1,81)$ & Super familia SurA_N_3[c107813] - Domínio N-terminal SurA & $2.06 \mathrm{e}-12$ \\
\hline refiNC_009882.1_:983971-984123 & Proténa hipotética A1G_05920 & $-2,20(2,36 ; 2,02)$ & DUF2269[pfam 10027] - Proteína predita integral de membrana (DUF2269) & $2.72 \mathrm{e}-13$ \\
\hline ref|NC_009882.1_c987677-987333 & Proteína hipotética A1G_05940 & $-2,70(2,81 ; 2,59)$ & HicB[pfam05534] - Familia HicB & $3.58 \mathrm{e}-16$ \\
\hline ref|NC_009882.1_:992452-993807 & Proteína hipotética A1G_05965 & $-2,50(2,76 ; 2,23)$ & MacB_PCD[pfam12704] - Domínio periplasmático MacB-like dos transportadores ABC & $1.44 \mathrm{e}-23$ \\
\hline ref|NC_009882.1_:c1015646-1014858 & Proténa hipotética A1G_06080 & $-4,51(4,90 ; 4,13)$ & DUF519[pfam 04378] - Proteína bacteriana de função desconhecida (DUF519), possivelmente secretada & $3.00 \mathrm{e}-116$ \\
\hline ref|NC $009882.1: 1043231-1043452$ & Proteína hipotética A1G 06275 & $-1,67(1,66 ; 1,67)$ & COG4100[COG4100] - Proteína da familia da cistationa beta-liase envolvida na resistência a alumínio & $6.60 \mathrm{e}-03$ \\
\hline ref|NC_009882.1_:c1050287-1049916 & Proténa hipotética A1G_06330 & $-2,69(2,86 ; 2,52)$ & ycf1[CHL00204] - Provisional Ycf1 & $7.56 \mathrm{e}-05$ \\
\hline ref|NC_009882.1_:c1052108-1051542 & Proteína hipotética A1G_06355 & $-2,39(2,72 ; 2,05)$ & PDDEXK_2[pfam12784] - Nuclease transposase PD-(D/E)XK & $1.29 \mathrm{e}-23$ \\
\hline reffNC 009882.1:1117305-1117733 & Proténa hipotética A1G 06700 & $-2,62(2,95 ; 2,28)$ & TH XRE[cd00093], Helix-turn-helix da familia de proteínas XRE-like & $5.36 \mathrm{e}-08$ \\
\hline ref|NC_009882.1_:c1164928-1163354 & Proténa hipotética A1G_06985 & $-1,84(2,01 ; 1,66)$ & Rotamase_2[pfam 13145], Domínio PPIC-tipo PPIASE & $4.55 \mathrm{e}-11$ \\
\hline ref|NC_009882.1_:c1175920-1175135 & Proteína hipotética A1G_07015 & $-1,80(1,71 ; 1,88)$ & COG1835[COG1835] - Aciltransferase predita & $2.38 \mathrm{e}-18$ \\
\hline reffNC_009882.1_:1237534-1238550 & Proténa hipotética A1G_07385 & $-2,11(2,28 ; 1,94)$ & YjgP_YjgQ[pfam03739] - Permease predita da família YjgP/YjgQ & $1.11 \mathrm{e}-59$ \\
\hline ref|NC_009882.1_:c1241821-1241363 & Proteína hipotética A1G_07415 & $-2,36(2,43 ; 2,29)$ & HsdM[COG0286] - Subunidade metiltransferase do sistema de restrição/modificação tipo 1 & $1.34 \mathrm{e}-17$ \\
\hline
\end{tabular}




\subsection{Confirmação do perfil de expressão de $\boldsymbol{R}$. rickettsii infectando fêmeas de $\boldsymbol{A}$. aureolatum}

A fim de confirmar os perfis de modulação dos genes $R$. rickettsii obtidos pela metodologia de microarranjos, selecionamos sete CDS moduladas pela temperatura e dez moduladas pela alimentação sanguínea para uma análise por RT-qPCR. A metionil tRNA sintetase (A1G_05810) foi utilizada para a normalização das quantidade de cDNA nas amostras, uma vez que apresentou os mesmos níveis de transcrição em todas as réplicas biológicas e condições avaliadas pelos microarranjos. Além disso, apresentou a menor variância dos valores de Cts entre as amostras nos experimentos de RT-qPCR. A eficiência dos oligonucleotídeos, determinada previamente às análises, variou entre 89 e 99\%, permitindo a determinação dos valores de fold-change pelo método $2^{-\Delta \Delta \mathrm{Ct}}$ (Livak, Schmittgen, 2001). Avaliamos cinco réplicas biológicas independentes (fêmeas inteiras de $A$. aureolatum) de cada grupo analisado nos experimentos de microarranjo: G1 (carrapatos não alimentados e mantidos a $25^{\circ} \mathrm{C}$ ), G2 (carrapatos não alimentados e mantidos a $35^{\circ} \mathrm{C}$ ) e G3 (carrapatos alimentados em cães por 3 dias). Os resultados de RT-qPCR tiveram uma correlação de $100 \%$ com os resultados previamente obtidos pelos microarranjos (Tabela 8). Dos 17 genes avaliados, 13 (76,47\%) apresentaram diferenças significativas $(p<0,05)$ em relação aos respectivos controles (G1 para a análise dos efeitos da elevação da temperatura e G2 para análise dos efeitos da alimentação sanguínea).

Tabela 8 - Validação dos dados de modulação dos microarranjos por RT-qPCR.

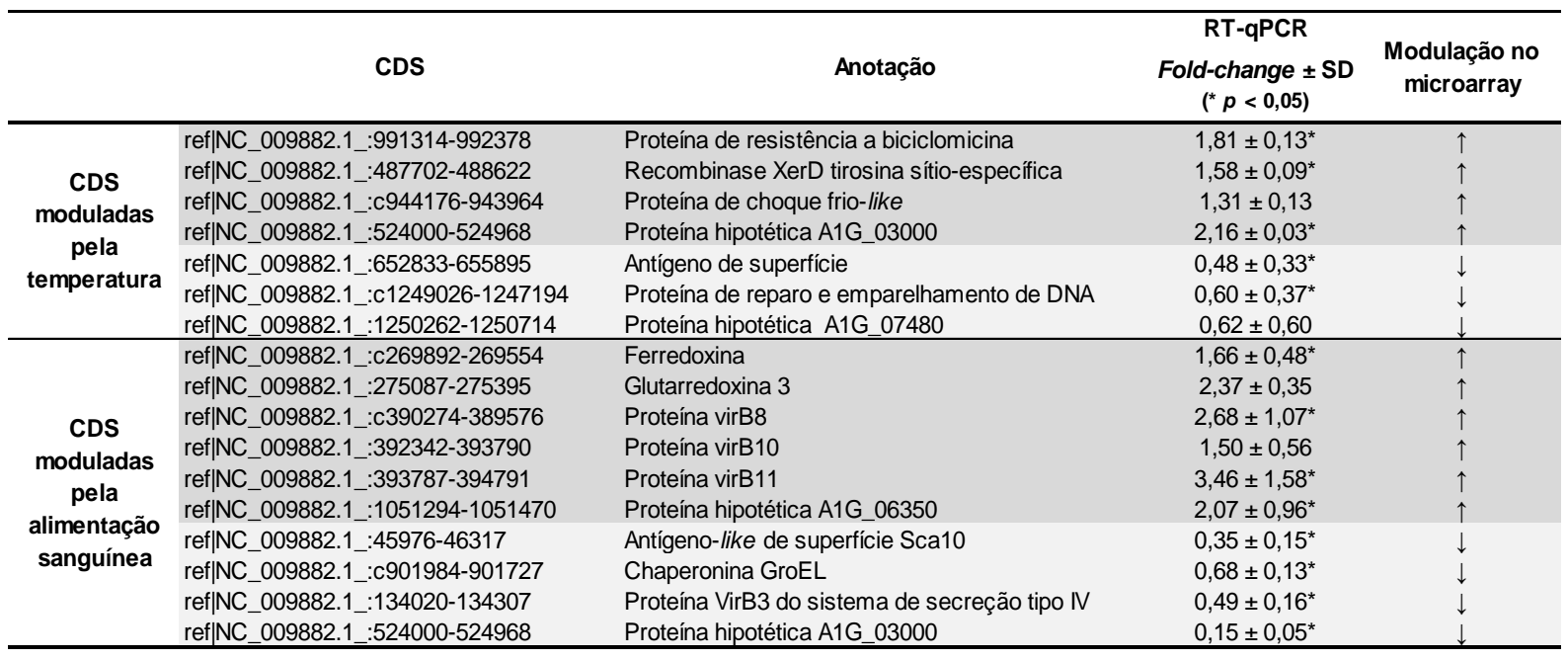




\subsection{Perfil de expressão de genes de $\boldsymbol{R}$. rickettsii modulados pela temperatura e alimentação sanguínea em glândulas salivares e intestinos de carrapatos $A$. aureolatum}

Com o objetivo de investigar a influência da elevação da temperatura e da exposição à alimentação sanguínea sobre o perfil transcricional de $R$. rickettsii em tecidos específicos do carrapato $A$. aureolatum, realizamos experimentos de RTqPCR microfluídica em larga escala. Para tal, fêmeas e machos infectados foram submetidos às mesmas condições anteriores: não alimentados e incubados a $25^{\circ} \mathrm{C}$ (G1) ou a $35^{\circ} \mathrm{C}$ (G2) por 3 dias ou alimentados em cães por 3 dias (G3). As glândulas salivares (SG) e intestino (MG) de cada exemplar foram dissecados e utilizados para a extração simultânea de RNA total e de DNA genômico. O número de bactérias por tecido foi quantificado por qPCR com sonda TaqMan específica para o gene gltA.

Dez amostras de SG e MG de fêmeas e de machos contendo em média 2,81 \pm $2,35 \times 10^{7}$ e 1,54 $\pm 1,70 \times 10^{7}$ bactérias, respectivamente, foram selecionadas para a análise do perfil transcricional de 95 genes (Apêndice B). Os genes analisados foram selecionados com base nos resultados das análises por microarranjos ou com base nos dados da literatura de fatores de virulência bacterianos, genes envolvidos no processo de estresse oxidativo, entre outros (Beckwith, 2013; Chan et al., 2009; Heinzen et al., 1993; Hendrick, Hartl, 1993; Li, Walker, 1998; Rahman et al., 2005; Rahman et al., 2013; Rikihisa, Lin, 2010; Uchiyama et al., 2006; Uchiyama, 2012; Walker et al., 2001; Winkler, 1976).

Os dados obtidos pelas reações foram inicialmente analisados pelo programa Fluidigm Real-Time PCR Analysis (Fluidigm Corporation). Os pares de oligonucleotídeos que não atingiram os valores mínimos de qualidade e que apresentaram eficiência menor que $89 \%$ ou que geraram mais de um produto de amplificação (amplicon) na curva de dissociação (melting curve) foram descartados das análises. Após a aplicação desses filtros, obtivemos o threshold cycle (Ct) de 70 genes, os quais seguiram para as análises de expressão.

Para selecionar o gene de referência mais adequado, utilizamos o programa NormFinder <http://www.mdl.dk/publicationsnormfinder.htm> (Andersen et al., 2004). Após a aplicação desse algoritmo, detectamos três genes com expressão constitutiva nas 120 amostras e que apresentaram os menores valores de estabilidade (stability value) e de erro-padrão [ribonuclease H (A1G_06145), proteína 
de montagem de superfície (A1G_02675) e proteína J do estágio 0 da esporulação (A1G_00545)]. A média desses três genes foi utilizada para o primeiro processo de normalização das quantidades de cDNA nas amostras. De maneira a quantificar a modulação gênica bacteriana em cada tecido analisado, utilizamos o método $2^{-\Delta \Delta C t}$ (Livak, Schmittgen, 2001). Não observamos diferença no perfil de expressão gênica de $R$. rickettsii infectando machos em relação a fêmeas. Dessa maneira, pudemos utilizar cada exemplar (macho ou fêmea) como uma réplica biológica nas análises.

Para determinar os efeitos da elevação da temperatura, comparamos a expressão de $R$. rickettsii em G2 (carrapatos não alimentados mantidos a $35^{\circ} \mathrm{C}$ ) e G1 (carrapatos não alimentados mantidos a $25^{\circ} \mathrm{C}$ ). Observamos que genes relacionados à virulência bacteriana, como proteínas de superfície e componentes do T4SS, além de possíveis efetores deste sistema de secreção (ankirinas), estão mais expressos nas glândulas salivares do que nos intestinos independentemente do gênero analisado (Figura 9). Considerando-se apenas genes com fold-changes $\geq 1,5$ e $p$-values $\leq 0,05$, observamos que a elevação da temperatura em $10{ }^{\circ} \mathrm{C}$ modulou 19 genes (14 induzidos e 5 reprimidos) nas glândulas salivares e 9 genes ( 2 induzidos e 7 reprimidos) nos intestinos (Tabela 9). 


\section{Figura 9 - Efeitos da temperatura sobre o perfil de expressão gênica de $\boldsymbol{R}$. rickettsii infectando glândulas salivares (SG) e intestinos (MG) de machos e fêmeas de $A$. aureolatum.}

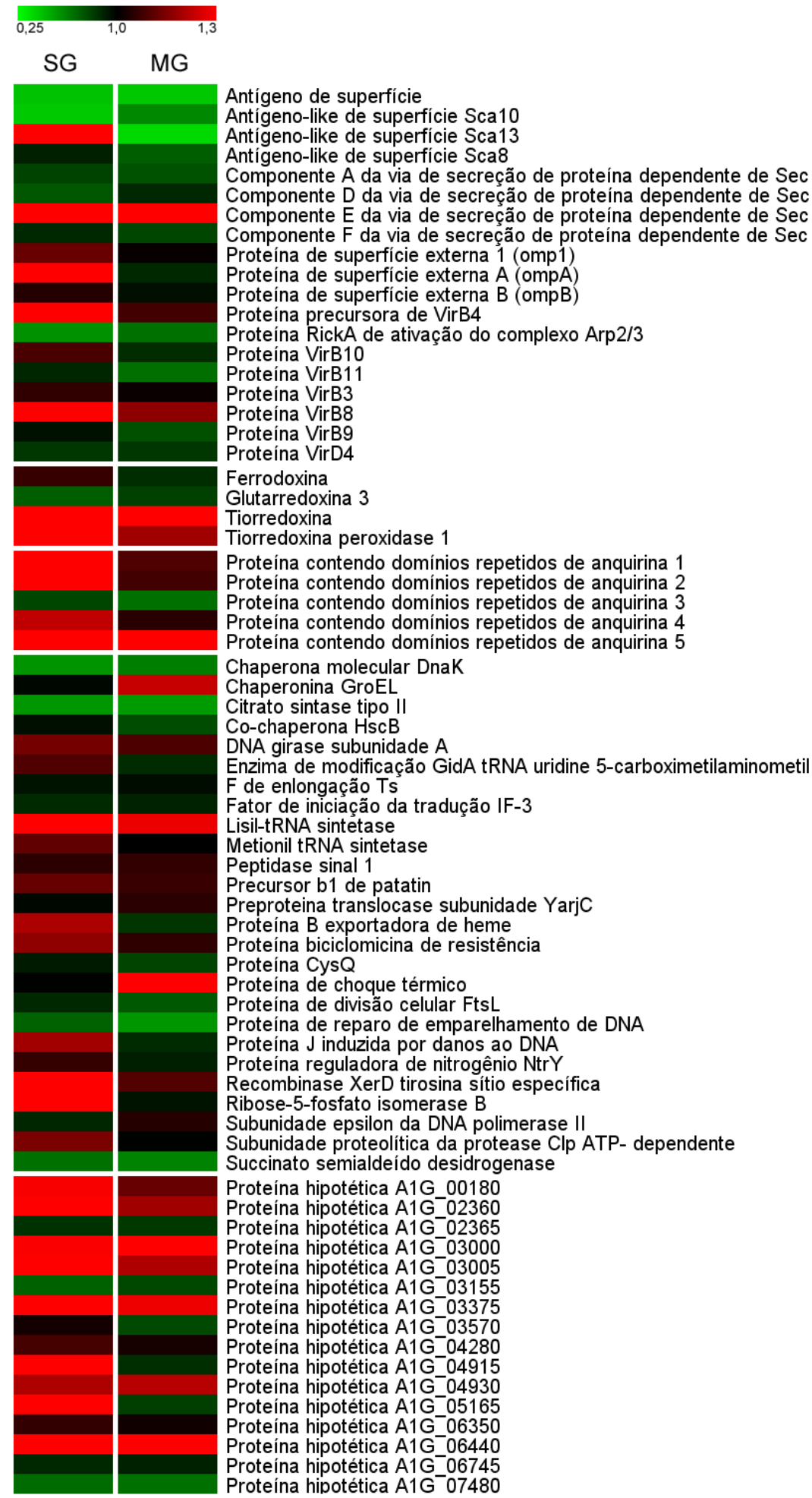

Nota: Os dados foram obtidos pelas análises de RT-qPCR microfluídica. A representação gráfica de heat-map representa genes mais expressos em vermelho e menos expresso em verde. 
Tabela 9 - CDS de $R$. rickettsii diferencialmente expressas pela exposição à elevação de temperatura em tecidos de $A$. aureolatum adultos.

\begin{tabular}{|c|c|c|c|c|c|c|}
\hline Tecido & $\begin{array}{c}\text { Perfil de } \\
\text { modulação }\end{array}$ & $\begin{array}{c}\text { Identificação } \\
\text { do gene }\end{array}$ & CDS & Anotação & Fold-change & $P$-value \\
\hline \multirow{19}{*}{$\begin{array}{l}\text { Glândula } \\
\text { salivar }\end{array}$} & \multirow{14}{*}{ Induzidos } & A1G_00010 & ref|NC_009882.1_:1082-1399 & tiorredoxina & 1,504 & 0,0000 \\
\hline & & A1G_00070 & ref|NC_009882.1_:c11968-11702 & proteína contendo domínios repetidos de anquirina & 2,790 & 0,0000 \\
\hline & & A1G_01005 & ref|NC_009882.1_:177150-177350 & componente $\mathrm{E}$ da via de secreção de proteína dependente de Sec & 1,602 & 0,0000 \\
\hline & & A1G_01255 & ref|NC_009882.1_:232567-232908 & proteína contendo domínios repetidos de anquirina & 1,628 & 0,0010 \\
\hline & & A1G_02115 & ref|NC_009882.1_:c373645-373484 & proteína de superfície externa $A$ (ompA) & 1,557 & 0,0134 \\
\hline & & A1G_02210 & ref|NC_009882.1_:c390274-389576 & proteína VirB8 & 1,664 & 0,0000 \\
\hline & & A1G_02360 & ref|NC_009882.1_:418652-418861 & proteína hipotética A1G_02360 & 1,702 & 0,0018 \\
\hline & & A1G_02785 & ref|NC_009882.1_:487702-488622 & recombinase XerD tirosina sítio-específica & 1,574 & 0,0005 \\
\hline & & A1G_02865 & ref|NC_009882.1_:500770-502338 & lisil tRNA sintetase & 1,863 & 0,0000 \\
\hline & & A1G_02955 & ref|NC_009882.1_:513850-514026 & proteína contendo domínios repetidos de anquirina & 2,155 & 0,0007 \\
\hline & & A1G_03005 & ref|NC_009882.1_:525229-525366 & proteína hipotética A1G_03005 & 1,759 & 0,0001 \\
\hline & & A1G_04915 & ref|NC_009882.1_:c830629-830507 & proteína hipotética A1G_04915 & 2,179 & 0,0022 \\
\hline & & A1G_06440 & ref|NC_009882.1_:c1061923-1061801 & proteína hipotética A1G_06440 & 2,249 & 0,0019 \\
\hline & & A1G_06915 & ref|NC_009882.1_:c1153524-1153240 & antígeno-like de superfície Sca13 & 1,671 & 0,0383 \\
\hline & \multirow{5}{*}{ Reprimidos } & A1G_00295 & ref|NC_009882.1_:45976-46317 & antígeno-like de superfície Sca10 & 0,409 & 0,0000 \\
\hline & & A1G_01335 & ref|NC_009882.1_:c248307-246424 & chaperona molecular DnaK & 0,563 & 0,0000 \\
\hline & & A1G_03790 & ref|NC_009882.1_:652833-655895 & antígeno de superfície & 0,428 & 0,0000 \\
\hline & & A1G_07170 & ref|NC_009882.1_:c1203242-1201938 & citrato sintase tipo II & 0,558 & 0,0000 \\
\hline & & Rrlowa_1080 & ref|NC_010263.2_:C856717-858162 & proteina RickA de ativação do complexo Arp2/3 & 0,573 & 0,0000 \\
\hline \multirow{9}{*}{ Intestinos } & \multirow{2}{*}{ Induzidos } & A1G_01005 & ref|NC_009882.1_:177150-177350 & componente $\mathrm{E}$ da via de secreção de proteína dependente de Sec & 1,521 & 0,0000 \\
\hline & & A1G_06440 & ref|NC_009882.1_:c1061923-1061801 & proteína hipotética A1G_06440 & 1,659 & 0,0459 \\
\hline & \multirow{7}{*}{ Reprimidos } & A1G_00295 & ref|NC_009882.1_:45976-46317 & antígeno-like de superfície Sca10 & 0,599 & 0,0004 \\
\hline & & A1G_01335 & ref|NC_009882.1_:c248307-246424 & chaperona molecular DnaK & 0,629 & 0,0001 \\
\hline & & A1G_03490 & ref|NC_009882.1_:608404-609831 & semialdeido succinato desidrogenase & 0,614 & 0,0000 \\
\hline & & A1G_03790 & ref|NC_009882.1_:652833-655895 & antígeno de superfície & 0,409 & 0,0000 \\
\hline & & A1G_06915 & ref|NC_009882.1_:c1153524-1153240 & antígeno-like de superfície Sca13 & 0,361 & 0,0076 \\
\hline & & A1G_07170 & ref|NC_009882.1_:c1203242-1201938 & citrato sintase tipo II & 0,544 & 0,0000 \\
\hline & & A1G_07470 & ref|NC 009882.1: c1249026-1247194 & proteína de reparo de emparelhamento de DNA & 0,557 & 0,0000 \\
\hline
\end{tabular}

Nota: A análise transcricional foi realizada por RT-qPCR microfluídica. 
Por fim, identificamos os conjuntos de genes modulados apenas nas glândulas salivares ou apenas nos intestinos dos carrapatos, de modo a criar uma assinatura gênica tecido-específica da bactéria frente à elevação da temperatura (Figura 10). Como componentes desta assinatura bacteriana, identificamos 12 genes (11 induzidos e 1 reprimido) que foram exclusivamente modulados em glândulas salivares e 2 genes reprimidos exclusivamente em intestinos. Portanto, além do aumento da temperatura em $10^{\circ} \mathrm{C}$ ter induzido a expressão de um número maior de genes nas glândulas salivares em comparação com o intestino (Figura 9), a assinatura das glândulas salivares frente a este estímulo também foi mais expressiva (Figura 10). Dentro desta assinatura, além de CDS de proteínas com função anotada, identificamos três CDS de proteínas hipotéticas. Duas delas (A1G_03005 e A1G_04915) não possuem nenhum domínio conservado descrito no CDD (Conserved Domain Database), enquanto a proteína hipotética A1G_02360 possui identidade com o domínio de ligação de ATP do fator de elongação 3 (e-value 2.19E-24). Assim, podemos assumir que o aumento de $10^{\circ} \mathrm{C}$ na temperatura modula diferencialmente a expressão nas glândulas e nos intestinos de $R$. rickettsii infectando $A$. aureolatum não alimentados. Esses genes podem ser utilizados no futuro como marcadores teciduais da exposição da bactéria à elevação da temperatura. 
Figura 10 - Assinatura gênica tecido-específica de $R$. rickettsii quando exposta à elevação da temperatura em $10^{\circ} \mathrm{C}$.

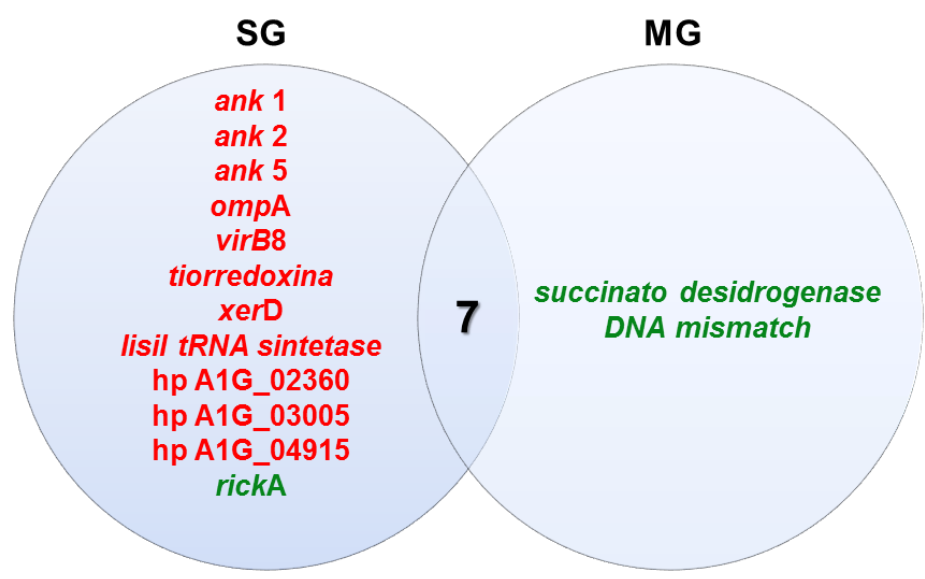

Nota: Os dados foram obtidos pelas análises de RT-qPCR microfluídica. O diagrama de Venn representa os conjuntos gênicos específicos de $R$. rickettsii em cada tecido do carrapato analisado e sua intersecção. Nas glândulas salivares, a assinatura é composta pelas CDS de três proteínas contendo domínios repetidos de ankirina (Ank1, Ank2 e Ank5), da proteína de superfície externa A (ompA), da proteína VirB8, da tiorredoxina, da recombinase XerD tirosina sítio-específica, da lisil tRNA sintetase, de três proteínas hipotéticas A1G_2360, A1G_4915, A1G3005, e da proteína RickA de ativação do complexo Arp2/3. Em intestinos, a assinatura é composta pelas CDS da semi-aldeido succinato desidrogenase e da proteína de reparo e emparelhamento de DNA (DNA mismatch). Em vermelho, CDS induzidas e em verde, CDS reprimidas.

Para determinar os efeitos da alimentação sanguínea sobre a expressão da bactéria em tecidos específicos do seu vetor, comparamos a expressão em G3 (carrapatos alimentados) versus G2 (carrapatos não alimentados e mantidos a 35 $\left.{ }^{\circ} \mathrm{C}\right)$. De maneira geral, a alimentação sanguínea também promoveu a modulação dos 70 genes analisados (Figura 11). Considerando como genes diferencialmente expressos aqueles com fold-changes $\geq 1,5$ e $p$-values $\leq 0,05$, a aquisição da alimentação sanguínea modulou 28 genes (5 induzidos e 23 reprimidos) nas glândulas salivares (Tabela 10) e 35 genes (15 induzidos e 20 reprimidos) nos intestinos (Tabela 11). Assim como na elevação da temperatura, conseguimos montar um conjunto de genes diferencialmente expressos apenas nas glândulas salivares ou no intestino. Dessa forma, conseguimos definir uma assinatura gênica tecido-específica da bactéria frente ao repasto sanguíneo realizado pelo carrapatovetor. Como componentes dessa assinatura, 5 genes foram exclusivamente modulados em glândulas salivares ( 1 induzido e 4 reprimidos) e 12 genes exclusivamente modulados em intestinos (11 induzidos e 1 reprimidos) (Figura 12). Diferentemente da elevação de temperatura, a alimentação sanguínea promoveu a 
modulação de um número maior de genes nos intestinos do que nas glândulas salivares. Além das proteínas com função anotada, identificamos três proteínas hipotéticas nas assinaturas, duas em glândulas salivares e uma nos intestinos. Destas, apenas a proteína hipotética A1G_6350 possui domínio de proteína secretada com função desconhecida (COG5510), segundo a busca por domínios conservados no CDD (Conserved Domain Database). 


\section{Figura 11 - Efeitos da alimentação sanguínea sobre o perfil de expressão gênica de $R$. rickettsii infectando glândulas salivares (SG) e intestinos (MG) de machos e fêmeas de $A$. aureolatum.}

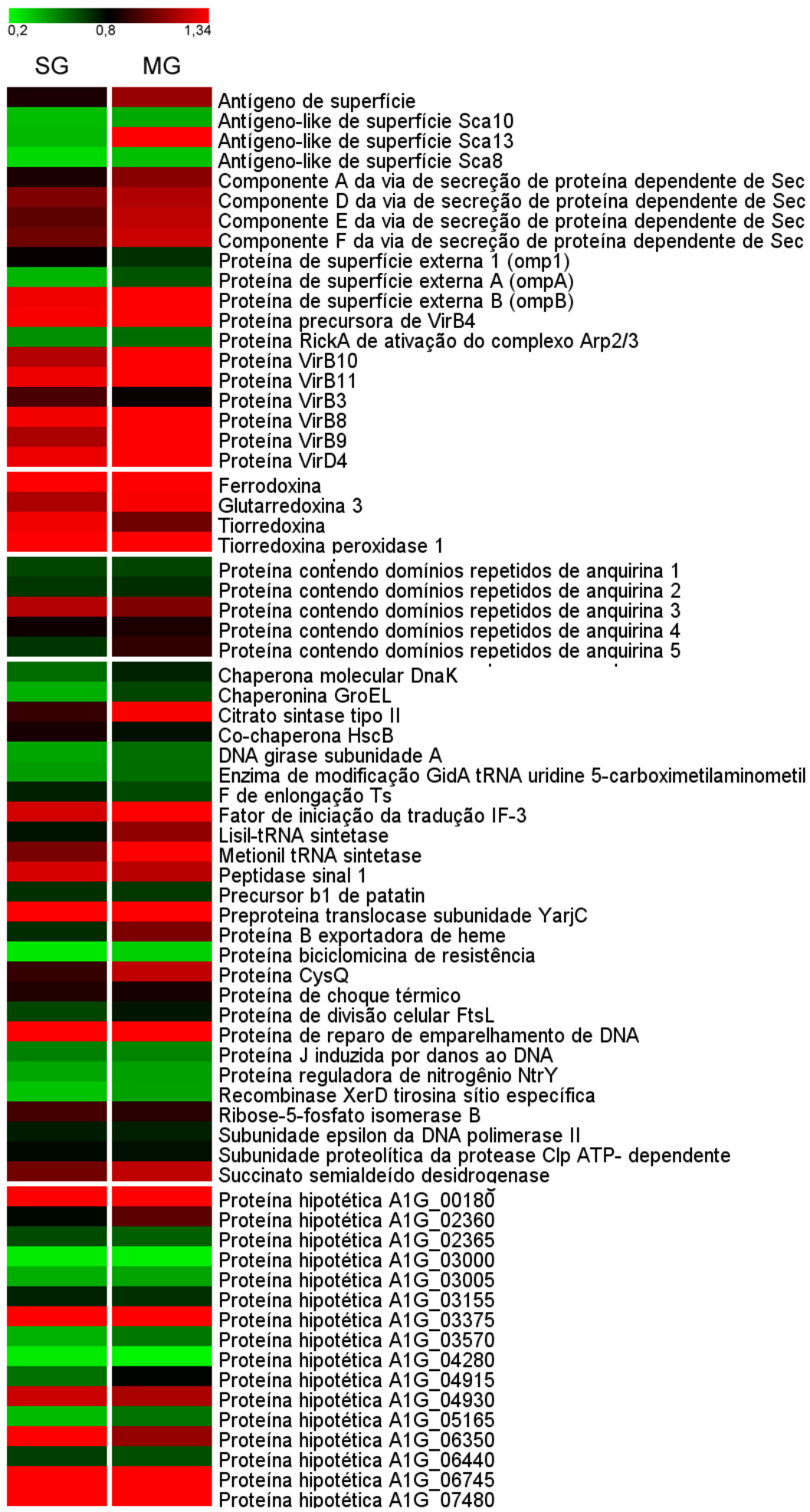

Nota: Os dados foram obtidos pelas análises de RT-qPCR microfluídica. A representação gráfica de heat-map representa genes mais expressos em vermelho e menos expressos em verde. 
Tabela 10 - CDS de $R$. rickettsii diferencialmente expressas pela exposição à alimentação sanguínea nas glândulas salivares de $A$. aureolatum adultos.

\begin{tabular}{|c|c|c|c|c|c|}
\hline $\begin{array}{l}\text { Perfil de } \\
\text { modulação }\end{array}$ & $\begin{array}{l}\text { Identificação } \\
\text { do gene }\end{array}$ & CDS & Anotação & Fold-change & $P$-value \\
\hline \multirow{5}{*}{ Induzidos } & A1G_00180 & ref|NC_009882.1_:c31143-30847 & proteína hipotética A1G_00180 & 1,60 & 0,0000 \\
\hline & A1G_02555 & ref|NC_009882.1_:C450224-449622 & tioredoxina peroxidase 1 & 1,55 & 0,0000 \\
\hline & A1G_06350 & ref|NC_009882.1_:1051294-1051470 & proteína hipotética A1G_06350 & 1,55 & 0,0005 \\
\hline & A1G 06745 & ref/NC $009882.1: c 1127890-1127534$ & proteína hipotética A1G 06745 & 1,68 & 0,0000 \\
\hline & A1G 07480 & ref|NC_009882.1_:1250262-1250714 & proteína hipotética A1G_07480 & 2,40 & 0,0000 \\
\hline \multirow{23}{*}{ Reprimidos } & A1G_00295 & ref|NC_009882.1_:45976-46317 & antígeno-like de superfície Sca10 & 0,35 & 0,0000 \\
\hline & A1G_00530 & ref|NC_009882.1_:79249-81117 & enzima de modificação GidA tRNA uridine 5-carboximetilaminometil & 0,43 & 0,0000 \\
\hline & A1G_01255 & ref|NC_009882.1_:232567-232908 & proteína contendo domínios repetidos de anquirina & 0,63 & 0,0034 \\
\hline & A1G_01335 & ref|NC_009882.1_:c248307-246424 & chaperona molecular DnaK & 0,55 & 0,0000 \\
\hline & A1G_01440 & ref|NC_009882.1_:262509-262940 & antígeno-like de superfície Sca8 & 0,29 & 0,0000 \\
\hline & A1G_01545 & ref|NC_009882.1_:c277476-277213 & DNA girase subunidade $A$ & 0,41 & 0,0001 \\
\hline & A1G_02115 & ref|NC_009882.1_:c373645-373484 & proteína de superfície externa $\mathrm{A}$ (ompA) & 0,37 & 0,0009 \\
\hline & $A 1 G 02385$ & ref|NC 009882.1:c421714-421487 & proteína hipotética A1G 02385 & 0,62 & 0,0085 \\
\hline & A1G_02785 & ref|NC_009882.1_:487702-488622 & recombinase XerD tirosina sítio-específica & 0,34 & 0,0000 \\
\hline & A1G_03000 & ref|NC_009882.1_:524000-524968 & proteína hipotética A1G_03000 & 0,24 & 0,0000 \\
\hline & A1G_03005 & ref|NC_009882.1_:525229-525366 & proteína hipotética A1G_03005 & 0,39 & 0,0000 \\
\hline & A1G_03570 & ref|NC_009882.1_:c621997-621737 & proteína hipotética A1G_03570 & 0,38 & 0,0000 \\
\hline & A1G_04280 & ref|NC_009882.1_:c730245-729259 & proteína hipotética A1G_04280 & 0,25 & 0,0000 \\
\hline & A1G_04750 & ref|NC_009882.1_:c803667-803269 & proteína de divisão celular FtsL & 0,64 & 0,0001 \\
\hline & A1G_04915 & ref|NC_009882.1_:c830629-830507 & proteína hipotética A1G_04915 & 0,53 & 0,0005 \\
\hline & A1G_05165 & ref|NC_009882.1_:c871627-869777 & proteína hipotética A1G_05165 & 0,36 & 0,0023 \\
\hline & A1G 05210 & ref|NC 009882.1 :c881085-879286 & proteína reguladora de nitrogênio NtrY & 0,41 & 0,0000 \\
\hline & A1G_05315 & ref|NC_009882.1_:c901984-901727 & chaperonina GroEL & 0,39 & 0,0000 \\
\hline & A1G_05960 & ref|NC_009882.1_:991314-992378 & proteína biciclomicina de resistência & 0,25 & 0,0000 \\
\hline & A1G_06440 & ref|NC_009882.1_:c1061923-1061801 & proteína hipotética A1G_06440 & 0,66 & 0,0243 \\
\hline & A1G 06915 & ref/NC $009882.1:$ : $1153524-1153240$ & antígeno-like de superfície Sca13 & 0,36 & 0,0001 \\
\hline & A1G_07375 & ref|NC_009882.1_:1236834-1237097 & proteína J induzida por danos ao DNA & 0,50 & 0,0001 \\
\hline & Rrlowa_1080 & ref|NC_010263.2:c856717-858162 & proteína RickA de ativação do complexo Arp2/3 & 0,46 & 0,0000 \\
\hline
\end{tabular}

Nota: A análise transcricional foi realizada por RT-qPCR microfluídica. 
Tabela 11 - CDS de $R$. rickettsii diferencialmente expressas pela exposição à alimentação sanguínea nos intestinos de $A$. aureolatum adultos.

\begin{tabular}{|c|c|c|c|c|c|}
\hline $\begin{array}{l}\text { Perfil de } \\
\text { modulação }\end{array}$ & $\begin{array}{l}\text { Identificação } \\
\text { do gene }\end{array}$ & CDS & Anotação & Fold-change & $P$-value \\
\hline \multirow{15}{*}{ Induzidos } & A1G 00180 & ref|NC 009882.1:c31143-30847 & proteína hipotética A1G 00180 & 1,70 & 0,0000 \\
\hline & A1G_02210 & ref|NC_009882.1_:c390274-389576 & proteína VirB8 & 1,88 & 0,0000 \\
\hline & A1G_02225 & ref|NC_009882.1_:391686-392159 & proteína VirB9 & 1,70 & 0,0000 \\
\hline & A1G_02230 & ref|NC_009882.1_:392342-393790 & proteína VirB10 & 1,68 & 0,0000 \\
\hline & A1G_02235 & ref|NC_009882.1_:393787-394791 & proteína VirB11 & 2,31 & 0,0000 \\
\hline & $A 1 G 02240$ & ref|NC 009882.1:394925-396700 & proteína VirD4 & 1,87 & 0,0000 \\
\hline & A1G_02555 & ref|NC_009882.1_:c450224-449622 & tioredoxina peroxidase 1 & 1,64 & 0,0000 \\
\hline & A1G_03375 & ref|NC_009882.1_:c591845-591552 & proteína hipotética A1G_03375 & 2,81 & 0,0017 \\
\hline & A1G_03930 & ref|NC_009882.1_:676576-677049 & fator de iniciação da trāucução IF-3 & 1,74 & 0,0000 \\
\hline & A1G_04935 & ref|NC_009882.1_:832252-832677 & preproteina translocase subunidade YarjC & 1,54 & 0,0000 \\
\hline & A1G 06030 & ref|NC_009882.1_:c1007464-1002500 & proteína de superfície externa B (ompB) & 1,95 & 0,0000 \\
\hline & A1G_06670 & ref|NC_009882.1_:1107497-1109929 & proteína precursora de VirB4 & 1,66 & 0,0000 \\
\hline & A1G_06745 & ref|NC_009882.1_:c1127890-1127534 & proteína hipotética A1G_06745 & 1,87 & 0,0000 \\
\hline & A1G_07470 & ref|NC_009882.1_:c1249026-1247194 & proteína de reparo de emparelhamento de DNA & 1,58 & 0,0001 \\
\hline & A1G_07480 & ref|NC_009882.1_:1250262-1250714 & proteína hipotética A1G_07480 & 2,60 & 0,0000 \\
\hline \multirow{20}{*}{ Reprimidos } & A1G 00295 & ref|NC_009882.1 :45976-46317 & antígeno-like de superfície Sca10 & 0,40 & 0,0000 \\
\hline & A1G_00530 & ref|NC_009882.1_:79249-81117 & enzima de modificação GidA tRNA uridine 5-carboximetilaminometil & 0,54 & 0,0003 \\
\hline & A1G 00685 & ref|NC_009882.1_:115915-116844 & fator de enlongação Ts & 0,63 & 0,0001 \\
\hline & A1G_01255 & ref|NC_009882.1_:232567-232908 & proteína contendo domínios repetidos de anquirina & 0,64 & 0,0107 \\
\hline & A1G 01440 & ref|NC $009882.1: 262509-262940$ & antígeno-like de superfície Sca8 & 0,35 & 0,0000 \\
\hline & A1G_01545 & ref|NC_009882.1_:2774476-277213 & DNA girase subunidade $A$ & 0,54 & 0,0003 \\
\hline & A1G_02115 & ref|NC_009882.1_:c373645-373484 & proteína de superfície externa $A$ (ompA) & 0,60 & 0,0126 \\
\hline & A1G_02385 & ref|NC_009882.1_:c421714-421487 & proteína hipotética A1G_02385 & 0,57 & 0,0001 \\
\hline & A1G_02785 & ref|NC_009882.1_:487702-488622 & recombinase XerD tirosina sítio específica & 0,42 & 0,0000 \\
\hline & $A 1 G 03000$ & ref|NC $009882.1: 524000-524968$ & proteína hipotética A1G 03000 & 0,24 & 0,0000 \\
\hline & A1G_03005 & ref|NC_009882.1_:525229-525366 & proteína hipotética A1G_03005 & 0,42 & 0,0000 \\
\hline & A1G_03570 & ref|NC_009882.1_:c621997-621737 & proteína hipotética A1G_03570 & 0,52 & 0,0013 \\
\hline & A1G_04280 & ref|NC_009882.1_:c730245-729259 & proteína hipotética A1G_04280 & 0,22 & 0,0000 \\
\hline & A1G_05165 & ref|NC_009882.1_:c871627-869777 & proteína hipotética A1G_05165 & 0,53 & 0,0220 \\
\hline & $A 1 G 05210$ & ref|NC_009882.1_:881085-879286 & proteína reguladora de nitrogênio NtrY & 0,43 & 0,0000 \\
\hline & A1G_05315 & ref|NC_009882.1_:c901984-901727 & chaperonina GroEL & 0,63 & 0,0004 \\
\hline & A1G_05960 & ref|NC_009882.1_:991314-992378 & proteína biciclomicina de resistência & 0,31 & 0,0000 \\
\hline & A1G_06440 & ref|NC_009882.1_:c1061923-1061801 & proteína hipotética A1G_06440 & 0,61 & 0,0042 \\
\hline & A1G_07375 & ref|NC_009882.1_:1236834-1237097 & proteína J induzida por danos ao DNA & 0,49 & 0,0022 \\
\hline & Rrlowa 1080 & ref|NC 010263.2 :c856717-858162 & proteína RickA de ativação do complexo Arp2/3 & 0,54 & 0,0001 \\
\hline
\end{tabular}

Nota: A análise transcricional foi realizada por RT-qPCR microfluídica. 
Figura 12 - Assinatura gênica tecido-específica de $R$. rickettsii quando exposta à alimentação sanguínea.

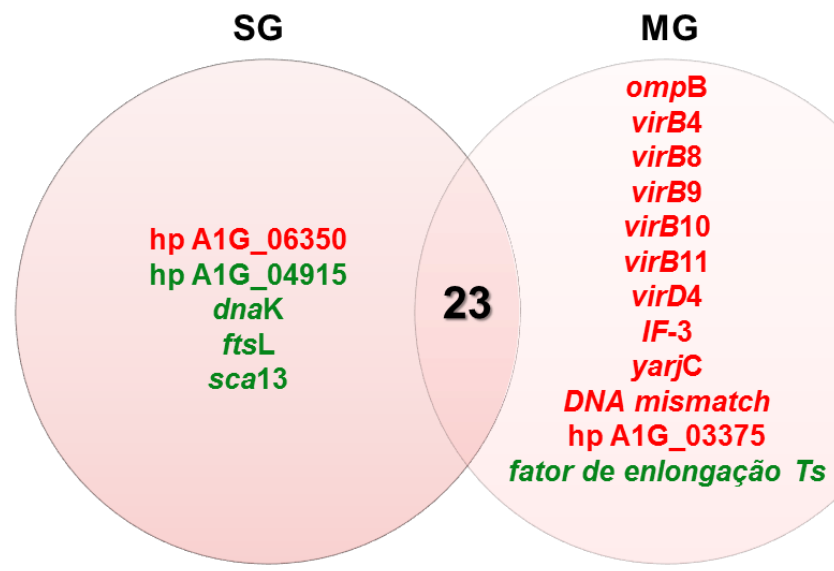

Nota: Os dados foram obtidos pelas análises de RT- qPCR microfluídica. O diagrama de Venn representa os conjuntos gênicos específicos de $R$. rickettsii em cada tecido do carrapato e sua intersecção. Nas glândulas salivares, a assinatura é composta pelas CDS das proteínas hipotéticas A1G_06350 e A1G_04915, além da chaperona molecular DnaK, da proteína de divisão celular FtsL e do antígeno-like de superfície Sca13. Em intestinos, a assinatura é composta pelas CDS da proteína de superfície externa B (ompB), de 6 componentes do sistema de secreção do tipo IV (VirB4, VirB8, VirB9, VirB10, VirB11, VirD4), do fator de iniciação da tradução IF-3, da subunidade YarjC da préproteína translocase, da proteína de reparo e emparelhamento de DNA (DNA mismatch), da proteína hipotética A1G_03375 e do fator de enlogação Ts. Em vermelho, CDS induzidas e em verde, CDS reprimidas pela condição biológica analisada.

Para avaliar os efeitos aditivos da temperatura e da alimentação sanguínea, analisamos comparativamente os níveis transcricionais da bactéria infectando os tecidos de $A$. aureolatum adultos não alimentados e incubados a $25^{\circ} \mathrm{C}(\mathrm{G} 1)$ versus carrapatos alimentados (G3). Os efeitos do aumento de temperatura combinados com a exposição à alimentação foram semelhantes aos efeitos da alimentação isoladamente quanto ao número e às CDS moduladas. Esses dados reforçam a premissa de que a elevação de temperatura, por si só, não tem um efeito tão significativo sobre os níveis transcricionais da bactéria quanto a alimentação sanguínea. Considerando-se fold-changes $\geq 1,5$ e $p$-values $\leq 0,05$, a elevação da temperatura somada à alimentação sanguínea modularam a expressão de 32 genes nas glândulas salivares (10 induzidos e 22 reprimidos) (Tabela 12) e 36 no intestino (13 induzidos e 23 reprimidos) (Tabela 13). A maioria dos genes (26) apresentou 0 mesmo perfil de modulação nos dois tecidos analisados. Dentre os genes modulados, 6 (3 induzidos e 3 reprimidos) caracterizam a assinatura gênica de $R$. rickettsii nas glândulas salivares enquanto 10 (6 induzidos e 4 reprimidos) caracterizam a assinatura nos intestinos (Figura 13). Dentre as proteínas hipotéticas 
que compõem essas assinaturas, uma delas (A1G_06350), modulada em glândulas salivares, também faz parte da assinatura de $R$. rickettsii infectando glândulas salivares expostas apenas à alimentação sanguínea. Como mencionado anteriormente, essa proteína possui domínio de proteína secretada de função desconhecida. A indução da proteína contendo domínios repetidos de ankirina 5 (Ank5), também faz parte desta assinatura. Conforme também já mencionado anteriormente, proteínas com domínio de ankirina são potenciais efetores do T4SS. Dentre as duas proteínas hipotéticas que compõem a assinatura gênica de $R$. rickettsii nos intestinos, a A1G_03005 não possui nenhum domínio conservado descrito enquanto a A1G_06745 possui domínio de proteína predita de membrana com função desconhecida (e-value 3.91e-67) (COG3671). 
Tabela 12 - CDS de $R$. rickettsii diferencialmente expressas nas glândulas salivares de $A$. aureolatum adultos pelo efeito aditivo da elevação de temperatura e da alimentação sanguínea.

\begin{tabular}{|c|c|c|c|c|c|}
\hline $\begin{array}{l}\text { Perfil de } \\
\text { modulação }\end{array}$ & $\begin{array}{l}\text { Identificação } \\
\text { do gene }\end{array}$ & CDS & Anotação & Fold-change & $P$-value \\
\hline \multirow{10}{*}{ Induzidos } & A1G_00070 & ref|NC_009882.1_c11968-11702 & proteína contendo domínios repetidos de ankirina & 1,89 & 0,0166 \\
\hline & A1G_00010 & ref|NC_009882.1_:1082-1399 & tiorredoxina & 1,98 & 0,0000 \\
\hline & A1G_00180 & ref|NC_009882.1_:c31143-30847 & proteína hipotética A1G_00180 & 2,07 & 0,0000 \\
\hline & A1G_01005 & ref|NC_009882.1_:177150-177350 & componente E da via de secreção de proteína dependente de Sec & 1,60 & 0,0000 \\
\hline & A1G_02210 & ref|NC_009882.1_:c390274-389576 & proteína VirB8 & 2,19 & 0,0000 \\
\hline & A1G_02555 & ref|NC_009882.1_:c450224-449622 & tioredoxina peroxidase 1 & 2,09 & 0,0000 \\
\hline & A1G_03375 & ref|NC_009882.1_:c591845-591552 & proteína hipotética A1G_03375 & 3,01 & 0,0174 \\
\hline & A1G_06350 & ref|NC_009882.1_:1051294-1051470 & proteína hipotética A1G_06350 & 1,64 & 0,0000 \\
\hline & A1G_06670 & ref|NC_009882.1_:1107497-1109929 & proteína precursora de VirB4 & 1,77 & 0,0000 \\
\hline & A1G 07480 & ref|NC_009882.1_:1250262-1250714 & proteína hipotética A1G_07480 & 1,64 & 0,0000 \\
\hline \multirow{22}{*}{ Reprimidos } & A1G_00295 & ref|NC_009882.1_:45976-46317 & antígeno-like de superfície Sca10 & 0,15 & 0,0000 \\
\hline & A1G_00530 & ref|NC_009882.1_:79249-81117 & enzima de modificação GidA tRNA uridine 5-carboximetilaminometil & 0,47 & 0,0000 \\
\hline & A1G_01335 & ref|NC_009882.1_:c248307-246424 & chaperona molecular DnaK & 0,31 & 0,0000 \\
\hline & A1G_01440 & ref|NC_009882.1_:262509-262940 & antígeno-like de superfície Sca8 & 0,26 & 0,0000 \\
\hline & A1G_01545 & ref|NC_009882.1_:c277476-277213 & DNA girase subunidade A & 0,47 & 0,0003 \\
\hline & A1G_02115 & ref|NC_009882.1_:c373645-373484 & proteína de superfície externa A (ompA) & 0,58 & 0,0184 \\
\hline & A1G_02385 & ref|NC_009882.1_:c421714-421487 & proteína hipotética A1G_02385 & 0,53 & 0,0018 \\
\hline & A1G_02785 & ref|NC_009882.1_:487702-488622 & recombinase XerD tirosina sítio-específica & 0,53 & 0,0000 \\
\hline & A1G_03000 & ref|NC_009882.1_:524000-524968 & proteína hipotética A1G_03000 & 0,32 & 0,0000 \\
\hline & A1G_03155 & ref|NC_009882.1_:555321-555569 & proteína hipotética A1G_03155 & 0,51 & 0,0000 \\
\hline & A1G_03570 & ref|NC_009882.1_:c621997-621737 & proteína hipotética A1G_03570 & 0,39 & 0,0000 \\
\hline & A1G_03790 & ref|NC_009882.1_:652833-655895 & antígeno de superfície & 0,37 & 0,0000 \\
\hline & A1G_04280 & ref|NC_009882.1_:c730245-729259 & proteína hipotética A1G_04280 & 0,27 & 0,0000 \\
\hline & A1G_04750 & ref|NC_009882.1_:c803667-803269 & proteína de divisão celular FtsL & 0,56 & 0,0000 \\
\hline & A1G_05165 & ref|NC_009882.1_:c871627-869777 & proteína hipotética A1G_05165 & 0,54 & 0,0371 \\
\hline & A1G_05210 & ref|NC_009882.1_:c881085-879286 & proteína reguladora de nitrogênio NtrY & 0,43 & 0,0000 \\
\hline & A1G_05315 & ref|NC_009882.1_:c901984-901727 & chaperonina GroEL & 0,38 & 0,0000 \\
\hline & A1G_05960 & ref|NC_009882.1_:991314-992378 & proteína biciclomicina de resistência & 0,30 & 0,0000 \\
\hline & A1G_06165 & ref|NC_009882.1_:1028222-1028911 & DNA polimerase II subunidade epsilon & 0,65 & 0,0000 \\
\hline & A1G_07170 & ref|NC_009882.1_:c1203242-1201938 & citrato sintase tipo II & 0,51 & 0,0000 \\
\hline & A1G_07375 & ref|NC_009882.1_:1236834-1237097 & proteína J induzida por danos ao DNA & 0,59 & 0,0030 \\
\hline & Rrlowa 1080 & ref|NC 010263.2 :c856717-858162 & proteina RickA de ativação do complexo Arp2/3 & 0,27 & 0,0000 \\
\hline
\end{tabular}

Nota: A análise transcricional foi realizada por RT-qPCR microfluídica. 
Tabela 13 - CDS de $R$. rickettsii diferencialmente expressas no intestino de $A$. aureolatum adultos pelo efeito aditivo da elevação de temperatura e da alimentação sanguínea.

\begin{tabular}{|c|c|c|c|c|c|}
\hline $\begin{array}{l}\text { Perfil de } \\
\text { modulação }\end{array}$ & $\begin{array}{l}\text { Identificação } \\
\text { do gene }\end{array}$ & CDS & Anotação & Fold-change & $P$-value \\
\hline \multirow{13}{*}{ Induzidos } & A1G_00180 & ref|NC_009882.1_:c31143-30847 & proteína hipotética A1G_00180 & 1,91 & 0,0000 \\
\hline & A1G_01005 & ref|NC_009882.1_:177150-177350 & componente $\mathrm{E}$ da via de secreção de proteína dependente de Sec & 1,83 & 0,0000 \\
\hline & A1G_02210 & ref|NC_009882.1_:c390274-389576 & proteína VirB8 & 2,20 & 0,0000 \\
\hline & A1G_02235 & ref|NC_009882.1_:393787-394791 & proteína VirB11 & 1,55 & 0,0000 \\
\hline & A1G_02240 & ref|NC_009882.1_:394925-396700 & proteína VirD4 & 1,56 & 0,0001 \\
\hline & A1G 02555 & ref|NC_009882.1_:450224-449622 & tioredoxina peroxidase 1 & 1,95 & 0,0000 \\
\hline & A1G_03375 & ref|NC_009882.1_:c591845-591552 & proteína hipotética A1G_03375 & 3,60 & 0,0005 \\
\hline & A1G_03930 & ref|NC_009882.1_:676576-677049 & fator de iniciação da tradução IF-3 & 1,56 & 0,0000 \\
\hline & A1G 04935 & ref|NC_009882.1_:832252-832677 & preproteina translocase subunidade YarjC & 1,62 & 0,0000 \\
\hline & A1G_06030 & ref|NC_009882.1_:c1007464-1002500 & proteína de superfície externa B (ompB) & 1,86 & 0,0000 \\
\hline & A1G_06670 & ref|NC_009882.1_:1107497-1109929 & proteína precursora de VirB4 & 1,79 & 0,0000 \\
\hline & A1G 06745 & ref|NC_009882.1_:c1127890-1127534 & proteína hipotética A1G 06745 & 1,69 & 0,0000 \\
\hline & A1G 07480 & refiNC_009882.1_:1250262-1250714 & proteína hipotética A1G 07480 & 1,74 & 0,0000 \\
\hline \multirow{23}{*}{ Reprimidos } & A1G_00295 & ref|NC_009882.1_:45976-46317 & antígeno-like de superfície Sca10 & 0,24 & 0,0000 \\
\hline & A1G 00530 & ref|NC $009882.1: 79249-81117$ & enzima de modificação GidA tRNA uridine 5-carboximetilaminometil & 0,47 & 0,0000 \\
\hline & A1G_00685 & ref|NC_009882.1_:115915-116844 & fator de enlongação Ts & 0,60 & 0,0000 \\
\hline & A1G_01335 & ref|NC_009882.1_:c248307-246424 & chaperona molecular DnaK & 0,45 & 0,0000 \\
\hline & A1G 01440 & ref|NC_009882.1_:262509-262940 & antígeno-like de superfície Sca8 & 0,25 & 0,0000 \\
\hline & A1G_01505 & ref|NC_009882.1_:c272234-271734 & proteína co-chaperona HscB & 0,59 & 0,0000 \\
\hline & A1G_01545 & ref|NC_009882.1_:c277476-277213 & DNA girase subunidade $A$ & 0,59 & 0,0002 \\
\hline & A1G 02115 & ref|NC_009882.1_c373645-373484 & proteína de superfície externa A (ompA) & 0,53 & 0,0022 \\
\hline & A1G_02385 & ref|NC_009882.1_:c421714-421487 & proteína hipotética A1G_02385 & 0,48 & 0,0000 \\
\hline & A1G_02785 & ref|NC_009882.1_:487702-488622 & recombinase XerD tirosina sítio-específica & 0,46 & 0,0000 \\
\hline & A1G_03000 & ref|NC_009882.1_:524000-524968 & proteína hipotética A1G_03000 & 0,35 & 0,0000 \\
\hline & A1G_03005 & ref|NC_009882.1_:525229-525366 & proteína hipotética A1G_03005 & 0,50 & 0,0000 \\
\hline & A1G_03155 & ref|NC_009882.1_:555321-555569 & proteína hipotética A1G_03155 & 0,54 & 0,0000 \\
\hline & A1G_03570 & ref|NC_009882.1_:c621997-621737 & proteína hipotética A1G_03570 & 0,40 & 0,0000 \\
\hline & A1G 03790 & ref|NC_009882.1_:652833-655895 & antígeno de superfície & 0,46 & 0,0000 \\
\hline & A1G_04280 & ref|NC_009882.1_:c730245-729259 & proteína hipotética A1G_04280 & 0,23 & 0,0000 \\
\hline & A1G_04750 & ref|NC_009882.1_:c803667-803269 & proteína de divisão celular FtsL & 0,55 & 0,0000 \\
\hline & A1G_05165 & ref|NC_009882.1_:c871627-869777 & proteína hipotética A1G_05165 & 0,43 & 0,0047 \\
\hline & A1G_05210 & ref|NC_009882.1_:c881085-879286 & proteína reguladora de nitrogênio NtrY & 0,39 & 0,0000 \\
\hline & A1G 05960 & ref|NC 009882.1:991314-992378 & proteína biciclomicina de resistência & 0,33 & 0,0000 \\
\hline & A1G_06915 & ref|NC_009882.1_:c1153524-1153240 & antígeno-like de superfície Sca13 & 0,52 & 0,0243 \\
\hline & A1G_07375 & ref|NC_009882.1_:1236834-1237097 & proteína J induzida por danos ao DNA & 0,42 & 0,0000 \\
\hline & Rrlowa 1080 & ref|NC $010263.2:$ : $856717-858162$ & proteina RickA de ativacão do complexo Arp2/3 & 0,36 & 0,0000 \\
\hline
\end{tabular}

Nota: A análise transcricional foi realizada por RT- qPCR microfluídica. 


\section{Figura 13 - Assinatura gênica tecido-específica de $R$. rickettsii exposta à elevação da temperatura e à alimentação sanguínea simultaneamente.}

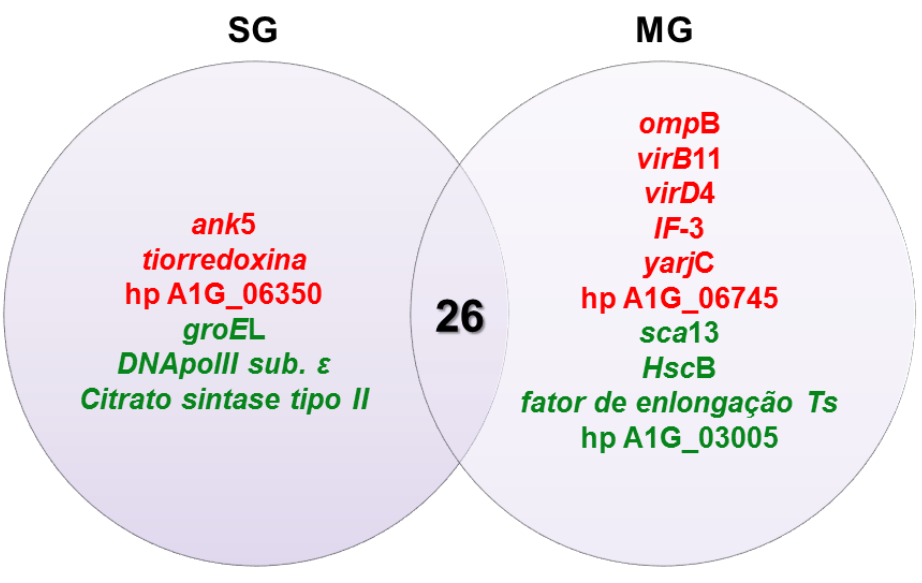

Nota: Os dados foram obtidos pelas análises de RT-qPCR microfluídica. O diagrama de Venn representa os conjuntos gênicos específicos de $R$. rickettsii em cada tecido do carrapato e sua intersecção. Nas glândulas salivares, a assinatura é composta pelas CDS da proteína contendo domínios repetidos de anquirina 5 (Ank5), tiorredoxina, proteína hipotética A1G_06350, chaperonina GroEL (GroEL), DNA polimerase III subunidade $\varepsilon$ e citrato sintase tipo II. Nos intestinos, a assinatura é composta pelas CDS de dois componentes do sistema de secreção do tipo IV (VirB11 e VirD4), fator de iniciação da tradução IF-3, subunidade YarjC da preproteina translocase, proteína de superfície externa B (OmpB), proteína hipotética A1G_06745, fator de enlongação TS, proteína cochaperona HscB, proteína hipotética A1G_03005 e antígeno-like de superfície Sca13. Em vermelho, CDS induzidas e em verde, CDS reprimidas.

\subsection{Expressão gênica de $R$. rickettsii em células BME26}

O perfil transcricional de $R$. rickettsii em células BME26 incubadas a $34{ }^{\circ} \mathrm{C}$ por 48 horas (fase exponencial de crescimento da bactérias nestas células) também foi avaliado por RT-qPCR. Observamos que todos os 70 genes expressos em tecidos de $A$. aureolatum também estão expressos in vitro (Tabela 14). Dessa forma, o cultivo celular poderá ser utilizado para estudos posteriores de interação carrapatoR. rickettsii. 
Tabela 14 - CDS de $R$. rickettsii expressas em células BME26 incubadas a $34^{\circ} \mathrm{C}$.

\begin{tabular}{|c|c|c|c|}
\hline $\begin{array}{c}\text { Identificação } \\
\text { do gene }\end{array}$ & CDS & Anotação & Média de $\mathrm{Ct} \pm \mathrm{SD}$ \\
\hline A1G_00010 & reff|NC_009882.1_:1082-1399 & tiorredoxina & $10,00 \pm 0,57$ \\
\hline A1G_00070 & reff|NC_009882.1_:c11968-11702 & proténa contendo domínios repetidos de anquirina 5 & $13,97 \pm 0,83$ \\
\hline A1G_00180 & reff|NC_009882.1_:C31143-30847 & proteína hipotética A1G_00180 & $09,64 \pm 0,54$ \\
\hline A1G_00295 & ref|NC_009882.1_:45976-46317 & antígeno-like de superfície Sca10 & $12,25 \pm 0,55$ \\
\hline A1G_00530 & ref|NC_009882.1_:79249-81117 & enzima de modificação GidA tRNA uridine 5-carboximetilaminometil & $12,25 \pm 0,60$ \\
\hline A1G_00545 & reff|NC_009882.1_:82427-83287 & proteína J do estágio 0 da esporulação & $9,59 \pm 0,48$ \\
\hline A1G_00810 & reff|NC_009882.1_:134020-134307 & proteína VirB3 componente do sistema de secreção tipo IV & $11,43 \pm 0,84$ \\
\hline A1G_01150 & reff|NC_009882.1_:c214853-212547 & proteína de superfície externa 1 (omp1) & $09,46 \pm 0,43$ \\
\hline A1G_01255 & ref|NC_009882.1_:232567-232908 & proteína contendo domínios repetidos de anquirina 1 & $14,25 \pm 0,68$ \\
\hline A1G_01335 & ref|NC_009882.1_:c248307-246424 & chaperona molecular DnaK & $10,25 \pm 0,54$ \\
\hline A1G_01440 & reffNC_009882.1_:262509-262940 & antígeno-like de superfície Sca8 & $17,01 \pm 0,88$ \\
\hline A1G_01500 & ref|NC_009882.1_:c271743-269956 & chaperona HscA & $12,17 \pm 0,65$ \\
\hline A1G_01505 & reff|NC_009882.1_:c272234-271734 & co-chaperona HscB & $12,71 \pm 0,73$ \\
\hline A1G_01525 & ref|NC_009882.1_:275087-275395 & glutarredoxina 3 & $11,15 \pm 0,55$ \\
\hline A1G_01545 & reff|NC_009882.1_:c277476-277213 & DNA girase subunidade $A$ & $16,22 \pm 0,74$ \\
\hline A1G_02035 & reff|NC_009882.1_:361975-362622 & proteína B exportadora de heme & $12,58 \pm 0,55$ \\
\hline A1G_02115 & ref|NC_009882.1_:c373645-373484 & proteína de superfície externa A (ompA) & $16,92 \pm 0,87$ \\
\hline A1G_02210 & ref|NC_009882.1_:c390274-389576 & proteína VirB8 & $14,56 \pm 0,94$ \\
\hline A1G_02225 & reff|NC_009882.1_:391686-392159 & proteína VirB9 & $12,33 \pm 0,73$ \\
\hline A1G_02230 & ref|NC_009882.1_:392342-393790 & proteína VirB10 & $11,54 \pm 0,52$ \\
\hline A1G_02235 & reff|NC_009882.1_:393787-394791 & proteína VirB11 & $11,02 \pm 0,55$ \\
\hline A1G_02240 & ref|NC_009882.1_:394925-396700 & proteína VirD4 & $11,08 \pm 0,86$ \\
\hline A1G_02285 & reff|NC_009882.1_:402739-403515 & proteína cysQ & $14,17 \pm 0,86$ \\
\hline A1G_02360 & reff|NC_009882.1_:418652-418861 & proteína hipotética A1G_02360 & $13,04 \pm 0,63$ \\
\hline A1G_02385 & ref|NC_009882.1_:c421714-421487 & proteína hipotética A1G_02385 & $13,7 \pm 0,48$ \\
\hline A1G_02435 & ref|NC_009882.1_:c431296-429542 & proteína AprD (alkaline protease secretion ATP-binding) & $15,72 \pm 0,96$ \\
\hline A1G_02675 & reffNC_009882.1_:c473994-471502 & proteína de membrana de ligação & $14,98 \pm 0,61$ \\
\hline A1G_02785 & ref|NC_009882.1_:487702-488622 & recombinase XerD tirosina sítio-específica & $12,35 \pm 0,66$ \\
\hline A1G_02865 & reff|NC_009882.1_:500770-502338 & lisil-tRNA sintetase & $15,34 \pm 0,81$ \\
\hline A1G_02955 & reff|NC_009882.1_:513850-514026 & proteína contendo domínios repetidos de anquirina 2 & $12,36 \pm 0,49$ \\
\hline A1G_02960 & reff|NC_009882.1_:514056-514307 & proteína contendo domínios repetidos de anquirina 3 & $12,09 \pm 0,62$ \\
\hline A1G_03005 & reff|NC_009882.1_:525229-525366 & proteína hipotética A1G_03005 & $15,97 \pm 0,98$ \\
\hline A1G_03155 & reff|NC_009882.1_:555321-555569 & proteína hipotética A1G_03155 & $13,38 \pm 0,58$ \\
\hline A1G_03300 & reff|NC_009882.1_:577205-579712 & leucil-tRNA sintetase & $15,95 \pm 1,27$ \\
\hline A1G_03445 & reff|NC_009882.1_:600281-600448 & proteína hipotética A1G_03445 & $14,39 \pm 0,54$ \\
\hline
\end{tabular}

Nota: A análise transcricional foi realizada por RT- qPCR microfluídica. 
Tabela 14 (Continuação).

\begin{tabular}{|c|c|c|c|}
\hline $\begin{array}{c}\text { Identificação } \\
\text { do gene }\end{array}$ & CDS & Anotação & Média de $\mathrm{Ct} \pm \mathrm{SD}$ \\
\hline A1G_03490 & ref|NC_009882.1_:608404-609831 & succinato semialdeído desidrogenase & $12,72 \pm 0,79$ \\
\hline A1G_03540 & ref|NC_009882.1_:616905-619217 & protease La ATP-dependente & $15,88 \pm 1,19$ \\
\hline A1G_03570 & ref|NC_009882.1_:c621997-621737 & proteína hipotética A1G_03570 & $15,14 \pm 0,83$ \\
\hline A1G_03790 & ref|NC_009882.1_:652833-655895 & antígeno de superfície & $11,95 \pm 0,55$ \\
\hline A1G_03930 & ref|NC_009882.1_:676576-677049 & fator de iniciação da tradução IF-3 & $10,77 \pm 0,46$ \\
\hline A1G_04200 & ref|NC_009882.1_:c720461-719856 & subunidade proteolítica da protease Clp ATP-dependente & $12,53 \pm 0,87$ \\
\hline A1G_04750 & ref|NC_009882.1_:c803667-803269 & proteína FtsL de divisão celular & $14,01 \pm 0,68$ \\
\hline A1G_04850 & ref|NC_009882.1_:c815948-815700 & proteína contendo domínios repetidos de anquirina 4 & $14,60 \pm 0,79$ \\
\hline A1G_04855 & ref|NC_009882.1_:c819688-816968 & componente A da via de secreção de proteína dependente de Sec & $12,51 \pm 0,57$ \\
\hline A1G_04915 & ref|NC_009882.1_:C830629-830507 & proteína hipotética A1G_04915 & $13,50 \pm 0,58$ \\
\hline A1G_04930 & ref|NC_009882.1_:832062-832241 & proteína hipotética A1G_04930 & $10,50 \pm 0,50$ \\
\hline A1G_04935 & reff|NC_009882.1_:832252-832677 & preproteina translocase subunidade YarjC & $9,43 \pm 0,48$ \\
\hline A1G_04940 & ref|NC_009882.1_:832661-834217 & componente $\mathrm{D}$ da via de secreção de proteína dependente de Sec & $11,41 \pm 0,56$ \\
\hline A1G_05085 & ref|NC_009882.1_:859725-861197 & precursor b1 de patatin & $8,78 \pm 0,46$ \\
\hline A1G_05165 & ref|NC_009882.1_:c871627-869777 & proteína hipotética A1G_05165 & $13,88 \pm 0,75$ \\
\hline A1G_05210 & ref|NC_009882.1_:c881085-879286 & proteína reguladora de nitrogênio NtrY & $12,84 \pm 0,63$ \\
\hline A1G_05315 & ref|NC_009882.1_:c901984-901727 & chaperonina GroEL & $13,31 \pm 0,77$ \\
\hline A1G_05455 & ref|NC_009882.1_:c922200-920899 & preproteína translocase subunidade $Y$ & $15,69 \pm 0,95$ \\
\hline A1G_05810 & ref|NC_009882.1_:c968241-966715 & metionil tRNA sintetase & $10,71 \pm 0,58$ \\
\hline A1G_05960 & ref|NC_009882.1_:991314-992378 & proteína de resistência a biciclomicina & $16,28 \pm 1,12$ \\
\hline A1G_06030 & ref|NC_009882.1_:c1007464-1002500 & proteína de superfície externa B (ompB) & $11,05 \pm 1,06$ \\
\hline A1G_06045 & ref|NC_009882.1_:c1009998-1009702 & proteína hipotética A1G_06045 & $13,84 \pm 0,64$ \\
\hline A1G_06100 & ref|NC_009882.1_:1020437-1020736 & proteína hipotética A1G_06100 & $15,71 \pm 0,64$ \\
\hline A1G_06145 & ref|NC_009882.1_:c1025600-1025133 & ribonuclease $\mathrm{H}$ & $10,16 \pm 0,70$ \\
\hline A1G_06350 & ref|NC_009882.1_:1051294-1051470 & proteína hipotética A1G_06350 & $11,37 \pm 0,50$ \\
\hline A1G_06440 & ref|NC_009882.1_:c1061923-1061801 & proteína hipotética A1G_06440 & $16,65 \pm 1,23$ \\
\hline A1G_06670 & ref|NC_009882.1_:1107497-1109929 & proteína precursora de VirB4 & $12,43 \pm 0,61$ \\
\hline A1G_06745 & ref|NC_009882.1_:c1127890-1127534 & proteína hipotética A1G_06745 & $11,41 \pm 0,72$ \\
\hline A1G_06915 & ref|NC_009882.1_:c1153524-1153240 & antígeno-like de superfície Sca13 & $16,67 \pm 0,83$ \\
\hline A1G_07055 & ref|NC_009882.1_:c1181808-1181458 & ferredoxina & $12,30 \pm 0,85$ \\
\hline A1G_07170 & ref|NC_009882.1_:c1203242-1201938 & citrato sintase tipo II & $11,37 \pm 0,53$ \\
\hline A1G_07355 & ref|NC_009882.1_:c1234383-1234144 & antitoxina do sistema StbD toxina-antitoxina & $15,59 \pm 0,93$ \\
\hline A1G_07375 & ref|NC_009882.1_:1236834-1237097 & proteína $\mathrm{J}$ induzida por danos no DNA & $15,71 \pm 0,48$ \\
\hline A1G_07480 & reff|NC_009882.1_:1250262-1250714 & proteína hipotética A1G_07480 & $12,80 \pm 0,52$ \\
\hline Rrlowa_1080 & ref|NC_010263.2_:c856717-858162 & proteina RickA de ativação do complexo Arp2/3 & $10,96 \pm 0,50$ \\
\hline
\end{tabular}




\section{DISCUSSÃO}

Rickettsia rickettsii, o agente etiológico da Febre Maculosa das Montanhas Rochosas (Rock Mountain Spotted Fever; RMSF) é uma $\alpha$-proteobactéria intracelular obrigatória, transmitida ao homem por diferentes espécies de carrapatos (Dantas Torres et al., 2012). Na região metropolitana da cidade de São Paulo, o carrapato Amblyomma aureolatum, que infesta cães domésticos e, portanto, apresenta grande proximidade com o homem, é um importante vetor (Labruna, 2009; Labruna et al., 2011; Pinter, Labruna, 2006; Vieira et al., 2004). Além de atuar como vetor de $R$. rickettsii, o carrapato $A$. aureolatum possui ainda um alto potencial de reservatório da bactéria, uma vez que, experimentos de infecção experimental demonstraram que $100 \%$ dos carrapatos de uma colônia mantida em laboratório tornam-se infectados (Labruna et al., 2008; Labruna et al., 2011).

Mesmo apresentando antibioticoterapia (tetraciclina e cloranfenicol) como alternativa terapêutica, a RMSF ainda é a mais letal das riquetsioses que acometem o homem, e suas taxas de letalidade no estado de São Paulo podem ultrapassar os 50\% <http://www.cve.saude.sp.gov.br/bepa/pdf/BEPA94_SUPLEMENTO_FMB.pdf>. A prevenção da doença, até o momento, baseia-se exclusivamente no controle das populações de carrapatos que transmitem a bactéria e na prevenção da exposição de humanos às áreas infestadas por esses carrapatos. Uma alternativa de profilaxia seria o desenvolvimento de uma vacina. Para isso, o conhecimento dos mecanismos moleculares da interação entre a bactéria e seus vetores é fundamental, podendo levar à identificação de potenciais alvos vacinais.

Como a regulação ao nível da transcrição desempenha um papel fundamental em procariotos, a determinação da expressão gênica de um patógeno durante a infecção do vetor ou do hospedeiro pode fornecer informações importantes sobre a relação patógeno-hospedeiro e, dessa forma, vem sendo empregada para o estudo de uma grande diversidade de agentes etiológicos (La et al., 2007; Raoult et al., 2008). Além disso, estes estudos podem permitir a identificação de potenciais alvos para o desenvolvimento de vacinas que impeçam a transmissão da bactéria pelo carrapato vetor para um vertebrado previamente vacinado. Esta estratégia foi previamente adotada, por exemplo, para o desenvolvimento da vacina LYMErix ${ }^{\mathrm{TM}}$, que se baseia no bloqueio da transmissão da bactéria Borrelia burgdorferi, agente 
etiológico da doença de Lyme, para pessoas previamente vacinadas (Sigal et al., 1998).

O genoma completo da cepa virulenta Sheila Smith de $R$. rickettsii (GenBank CP000848.1) foi elucidado em 2008 por Ellison e colaboradores, tornando possível a utilização de metodologias de análise de expressão gênica em larga escala, tais como microarranjos, para o estudo funcional dos genes desta bactéria. Os microarranjos vêm sendo amplamente utilizados para a detecção de alterações na expressão gênica de bactérias (Kazmierczak et al., 2003; Ng et al., 2003), incluindo riquétsias (Audia et al., 2008; Dreher-Lesnick et al., 2008; Ellison et al., 2008; Ellison et al., 2009; La et al., 2007). Através da utilização desta metodologia, nós investigamos os efeitos de dois estímulos ambientais sobre o perfil de expressão gênica global de $R$. rickettsii infectando carrapatos $A$. aureolatum: (i) a elevação da temperatura em $10{ }^{\circ} \mathrm{C}$ e (ii) a exposição aos fatores da refeição sanguínea adquirida pelo vetor. $R$. rickettsii é naturalmente exposta a esses dois estímulos quando o carrapato infectado em jejum, livre no ambiente, encontra seu hospedeiro vertebrado, fixa-se à sua pele aquecida e inicia a alimentação sanguínea. Ambos foram previamente associados à reativação da virulência desta bactéria em carrapatos (Gilford, Price, 1955; Hayes, Burgdorfer, 1982; Policastro et al., 1997; Spencer, Parker, 1923). Porém, os fatores responsáveis pela conversão do fenótipo virulento em avirulento não foram completamente elucidados até o momento.

Inicialmente, customizamos os microarranjos de oligonucleotídeos com base no genoma completo da cepa virulenta Sheila Smith de $R$. rickettsii, a única cepa com genoma completo disponível nos bancos de dados públicos na fase da customização. Atualmente, diversas cepas de $R$. rickettsii tiveram seus genomas disponibilizados no GeneBank, incluindo uma denominada Brazilian. Entretanto, nenhuma informação relacionada à sua origem ou qualquer característica biológica (por exemplo, virulência) foi apresentada. Na comparação genômica da cepa Sheila Smith com a cepa avirulenta lowa, 143 deleções e 492 polimorfismos de base única (SNPs) foram identificados (Ellison et al., 2008). Dentre os SNPs, 339 localizam-se em fase aberta de leitura (open reading frames, ORFs), mas apenas 188 SNPs resultam em substituições de aminoácidos não sinônimas (Ellison et al., 2008). Ainda neste estudo, somente quatro genes foram diferencialmente expressos quando o RNA das cepas virulentas Sheila Smith e $R$ foram hibridizados em microarranjos da própria cepa Sheila Smith e também da cepa lowa. Assim, estes 
resultados indicam que as diferenças genômicas entre cepas não alteram sua expressão gênica (Ellison et al., 2008).

Para a padronização dos procedimentos de preparação e marcação de amostras para a hibridização com os microarranjos, buscamos, primeiramente, uma forma de obter grandes quantidades de RNA de $R$. rickettsii. Para isso, uma linhagem de células embrionárias do carrapato Rhipicephalus (Boophilus) microplus (BME26) mantida em cultivo foram infectadas com a cepa Taiaçu de $R$. rickettsii. A propagação de microorganismos, incluindo os intracelulares obrigatórios, em diferentes linhagens de células de carrapatos in vitro já foi descrita na literatura, como, por exemplo, o cultivo de bactérias dos gêneros Ehrlichia e Anaplasma (para revisão, veja Bell-Sakyi et al., 2007). O cultivo in vitro de bactérias do gênero Rickettsia em células de carrapato também já foi previamente reportado, como, por exemplo, o cultivo de $R$. felis em células embrionárias de $I$. scapularis (ISE6) (Pornwiroon et al., 2006) e de $R$. raoultii em células embrionárias de Dermacentor reticulatus (Alberdi et al., 2012). Contudo, a infecção in vitro de $R$. rickettsii, em particular, tem sido bem pouco explorada e pouco descrita na literatura (Ellison et al., 2009). Uma das linhagens celulares de carrapato bem descrita na literatura é a BME26, a qual foi caracterizada celular e molecularmente por Esteves e colaboradores (2008). Nessas células, a adesão de Borrelia burgdorferi (Spirochaetales: Spirochaetaceae) (Kurtti, 1993) e a propagação de Anaplasma marginale (Esteves et al., 2009) foram reportadas. A cepa Taiaçu de $R$. rickettsii foi capaz de infectar as células BME26 (Figura 3) em todas as condições analisadas, incluindo diferentes pHs, temperaturas de incubação e MOI. Essa é a primeira vez que uma cepa brasileira de $R$. rickettsii foi estabelecida em células de carrapato mantidas in vitro. A curva de crescimento bacteriano nas células BME26 foi determinada por qPCR com a sonda $\operatorname{TaqMan}^{\circledR}$ específica para o gene da citrato sintase (gltA) de Rickettsia spp (Figura 4). Observamos que a quantidade de bactérias aumenta em uma ordem de grandeza a cada $18 \mathrm{~h}$, sendo que após $60 \mathrm{~h}$ do início da infecção ocorre o descolamento da maior parte das células da monocamada. A curva de crescimento de $R$. rickettsii e o efeito citopático da infecção sobre as células BME26 foram semelhantes ao previamente observado em outros cultivos celulares (Policastro et al., 1997). Com a curva de crescimento, pudemos observar que as bactérias, nessas condições, se encontravam em fase log de crescimento $48 \mathrm{~h}$ após a adição do inóculo ao cultivo celular. 
Após a obtenção de RNA de $R$. rickettsii na fase log de crescimento em células BME26, prosseguimos com a padronização dos procedimentos de preparação de amostras para os experimentos de microarranjo. Os resultados da padronização mostraram que enquanto a amplificação do cDNA nas amostras era um passo fundamental para a obtenção de sinais satisfatórios de fluorescência, a remoção do RNAm eucariótico não era (Figura 2). De fato, o processo de amplificação linear global do RNA, como descrito na literatura (Kang et al., 2011; La et al., 2007; Lawson, Johnston, 2006), é um processo fundamental para obtenção de dados transcricionais de alta qualidade. Além disso, um melhor sinal de fluorescência foi obtido com o kit de marcação Genomic DNA ULS ${ }^{\text {TM }}$ Labeling (Agilent Technologies) (Figura 5). Esse resultado deve-se ao fato de que, nesse processo, o acoplamento dos corantes Cy3 e Cy5 ao ácido nucleico independe da presença de um nucleotídeo modificado o que é um pré-requisito para a marcação com o FairPaly III Labeling Kit.

Com os procedimentos para os experimentos de microarranjos padronizados, seguimos para as análises da expressão gênica global de $R$. rickettsii infectando órgãos de fêmeas adultas de $A$. aureolatum. Este corresponde ao primeiro relato da expressão gênica global de $R$. rickettsii infectando um carrapato-vetor natural. Nossos resultados demonstraram que ambos os estímulos ambientais favoreceram - crescimento de $R$. rickettsii, uma vez que diferenças significativas foram observadas na carga bacteriana em carrapatos não alimentados incubados a $25^{\circ} \mathrm{C}$ em comparação com carrapatos não alimentados e incubados a $35{ }^{\circ} \mathrm{C}$ ou alimentados (Figura 6). Além disso, a elevação da temperatura e a alimentação sanguínea modularam de maneira expressiva o perfil transcricional global de $R$. rickettsii. Entretanto, a influência da alimentação sanguínea sobre o perfil transcricional da bactéria foi maior se comparado à elevação de temperatura, modulando cinco vezes mais genes (Tabelas 2 a 4 e Anexos C a E). Esse efeito maior deflagrado pela alimentação pode estar associado à maior oferta de nutrientes. De fato, a indução de genes que estão diretamente relacionados com produção e conversão de energia (oito genes) além de replicação, recombinação e reparo (oito genes) foi deflagrada apenas pela exposição à alimentação.

Por outro lado, a elevação de $10{ }^{\circ} \mathrm{C}$ de temperatura estimulou de maneira mais discreta a expressão gênica global da bactéria, reprimindo genes relacionados ao metabolismo e transporte de carboidrato (i), nucleotídeos (ii) e lipídeos (iii) além de 
genes relacionados a produção e conversão de energia (iv) e replicação, recombinação e reparo. Embora $R$. rickettsii tenha reagido transcricionalmente à elevação da temperatura, o aumento em $10^{\circ} \mathrm{C}$ não provocou uma resposta característica de choque térmico. As análises globais identificaram a indução de apenas uma proteína de choque térmico (GrpE) e de uma proteína de choque frio (A1G_05630). Esses dados indicam que a elevação da temperatura em $10^{\circ} \mathrm{C}$ possa ser encarado como um desafio natural para $R$. rickettsii. De fato, um estudo prévio dos efeitos de variações da temperatura de incubação (de $22{ }^{\circ} \mathrm{C}$ para $37^{\circ} \mathrm{C}$ em células de carrapato em cultivo ou de $25^{\circ} \mathrm{C}$ para $34^{\circ} \mathrm{C}$ em células Vero) mostrou uma discreta modulação gênica de $R$. rickettsii. Uma modulação significativa (56 genes) foi detectada apenas quando as células foram expostas a uma variação de $30{ }^{\circ} \mathrm{C}$ (Ellison et al., 2009). Proteínas de choque térmico como GroES, GroEL e DnaK foram reprimidas quando a bactéria foi exposta a um decréscimo de $30{ }^{\circ} \mathrm{C}$. Diferentemente, um discreto decréscimo de temperatura (de $37{ }^{\circ} \mathrm{C}$ a $25{ }^{\circ} \mathrm{C}$ ) ocasionou a repressão de diversos genes de $R$. typhi infectando células Vero, incluindo genes codificadores de chaperonas e proteínas de choque térmico (Dreher-Lesnick et al., 2008).

Além de genes possivelmente associados à multiplicação bacteriana, a alimentação sanguínea promoveu a modulação de um conjunto de genes associado a tráfego intracelular e secreção, incluindo componentes do sistema de secreção tipo IV (T4SS). Esse sistema é caracterizado por um complexo proteico ancorado na membrana da bactéria e que permite o transporte de macromoléculas, conhecidas como efetores, para a célula hospedeira. Os efetores interagem com proteínas da célula hospedeira, auxiliando a sobrevivência intracelular da bactéria (Voth et al., 2012). Esse sistema de secreção, bem como seus efetores, tem sido estudado em outros membros da ordem Rickettsiales como Anaplasma phagocytophilum e Ehrlichia chaffeensis (Rikihisa, Lin, 2010), além de Coxiella burnetii (Chen et al., 2010). Nossos dados de transcrição global demonstraram que a alimentação sanguínea modulou significativamente quase a totalidade dos genes que codificam os componentes do T4SS de $R$. rickettsii. A expressão de virB3, virB8 e virB11 foi estatisticamente validada por RT-qPCR. Esses dados indicam que a secreção de efetores por esse sistema bacteriano pode ser importante durante a aquisição da alimentação sanguínea pelo vetor. Entretanto, enquanto houve a indução de virB8, virB9, virB10, virB11, e virD4 pelo estímulo, a expressão de virB3 foi reprimida. Esse 
perfil pode ser justificado pela diferente localização desse componente no cromossomo de $R$. rickettsii (Figura 14), indicando que, provavelmente, esse gene seja controlado por um mecanismo regulatório diferente. Duas proteínas hipotéticas (A1G_00820 e A1G_00825) localizadas a jusante de virB3 também foram reprimidas. Ambas as proteínas hipotéticas contém domínios da proteína VirB6 (Tabela 7). A presença de duas cópias de VirB6 em $R$. rickettsii confirma análises anteriores de componentes do T4SS de outras espécies de bactérias do gênero Rickettsia (Gillespie et al., 2009). Além disso, outra proteína hipotética (A1G_01380) que foi induzida pela alimentação sanguínea possui domínios da proteína VirB2 (Tabela 6). Interessantemente, essa é a primeira descrição deste componente do sistema em $R$. rickettsii, considerado ausente anteriormente (Gillespie et al., 2009).

Figura 14 - Localização e orientação dos genes codificadores de componentes do T4SS reprimidos (A) ou induzidos (B) pela alimentação sanguínea no cromossomo de $R$. rickettsii.

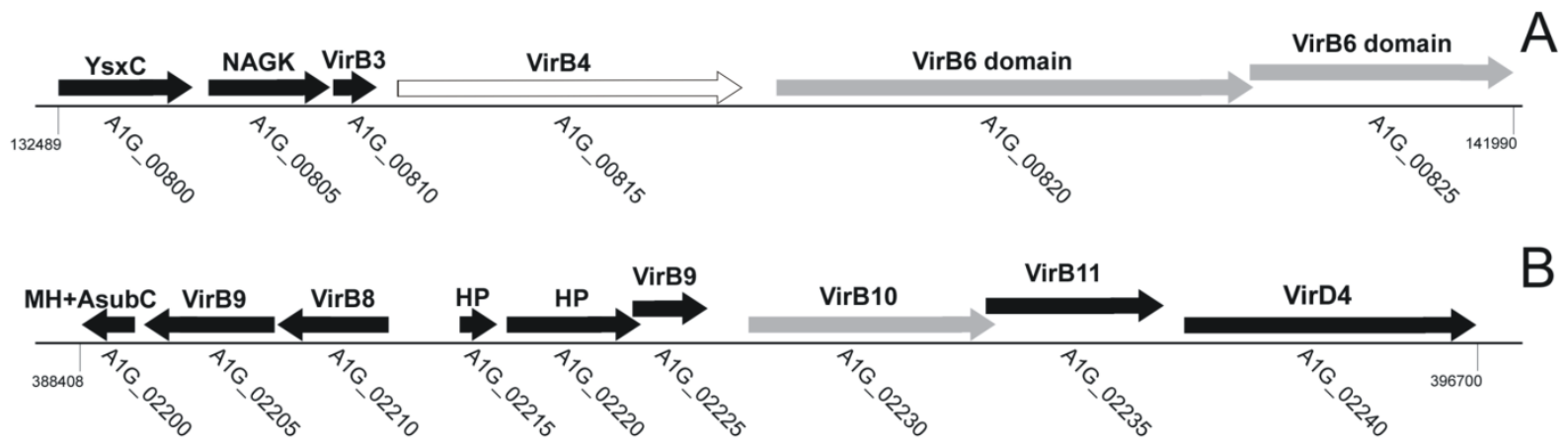

Nota: As setas pretas representam genes cuja modulação foi observada nas duas réplicas biológicas analisadas e as setas cinzas representam os genes cuja modulação foi observada em apenas uma das réplicas. A modulação da ATPase VirB4 (A1G_00815, seta branca) não foi observada.

Diferentemente do observado em $R$. rickettsii, a expressão gênica de componentes do T4SS de $R$. conorii foi induzida pela depleção de nutrientes durante a infecção de células Vero (La et al., 2007). Sob o mesmo aspecto de depleção nutricional, Ellison e colaboradores (2009) estudaram a influência de componentes do sangue na expressão gênica global de $R$. rickettsii durante a infecção in vitro de células Vero e de uma linhagem de células embrionárias do carrapato Ixodes scapularis (ISE6). Neste trabalho, foi avaliado o perfil transcricional da bactéria quando um agente quelante de ferro, com atividade inibitória sobre o crescimento de patógenos intracelulares, foi adicionado ao meio de cultura. Foi detectada uma 
alteração no crescimento bacteriano e a modulação de apenas cinco genes com fold-change $\geq 3.0$. Como esses genes codificam proteínas hipotéticas, os autores não concluíram a relação entre o estímulo ambiental e a modulação da expressão dos mesmos.

Recentemente, reações em cadeia da polimerase precedida por transcrição reversa (RT-qPCR) em circuitos microfluídicos vêm sendo utilizadas a fim de analisar, em larga escala, perfis de expressão de múltiplos genes e múltiplas amostras simultaneamente. Um exemplo é a plataforma conhecida como Biomark high-throughput RT-qPCR (Fluidigm Corporation), a qual se baseia em uma análise simultânea de até 96 amostras contra até 96 pares de oligonucleotídeos. Essa metodologia também é aplicada para análises de transcrição de uma única célula (Citri et al., 2011) e para a análise da expressão de micro RNAs (Jang et al., 2011). Além disso, é utilizada em análises genômicas, tais como busca por mutações e estabelecimento de assinaturas gênicas (Patel et al., 2012; Rosa et al., 2012). Utilizando essa plataforma, analisamos o perfil de expressão de todos os componentes do T4SS nas glândulas salivares e nos intestinos de fêmeas e machos adultos. Os componentes VirB4, VirB8, VirB9, VirB10, VirB11 e VirD4 foram induzidos em ambos os tecidos de ambos os gêneros (Tabela 11). Esse resultado sugere que a secreção de efetores da célula bacteriana para as células do intestino dos carrapatos seja promovida pela alimentação, permitindo a invasão dessa primeira barreira físico-química e assegurando o sucesso da colonização. Além disso, esses genes também fazem parte da assinatura transcricional da bactéria em intestinos de carrapatos alimentados (Figura 12). O uso de assinaturas gênicas tem sido relatada, principalmente em estudos humanos, a fim de se estabelecerem padrões para alvos terapêuticos (Patel et al., 2012; Shi et al., 2012), perfis de diagnóstico (Johansson et al., 2011) e até definição de prognósticos (Kumar et al., 2013; Peterson, 2013). Um único estudo para a definição de uma assinatura gênica foi reportado para bactérias do gênero Rickettsia (Renesto et al., 2008). Nesse trabalho, uma assinatura de Rickettsia conorii infectando a pele de humanos diagnosticados com a Febre Maculosa do Mediterrâneo foi definida, o qual auxiliou a identificação de novas características da patogenia pele-específica. Assim, a identificação das assinaturas específicas de $R$. rickettsii em intestinos e glândulas salivares de carrapatos poderão não somente auxiliar o entendimento das interações 
tecido-específicas, como também podem direcionar os futuros estudos funcionais para identificação de possíveis alvos de bloqueio da infecção.

Também avaliamos algumas das moléculas que conhecidamente atuam como efetores do T4SS de bactérias. Essas proteínas, que contêm domínios eucarióticos repetidos de anquirina (sendo por isso conhecida como Anks) estão envolvidas na interação proteína-proteína. Em algumas bactérias intracelulares, já foi demonstrado que as proteínas Anks secretadas no citoplasma da célula hospedeira onde interagem com proteínas do próprio hospedeiro (Habyarimana et al., 2008; Lin et al., 2007; Pan et al., 2008; Park et al., 2004; Rikihisa, Lin, 2010). Na célula hospedeira, podem desempenhar diferentes funções, tais como regulação de ciclo celular e transcrição gênica, interação de citoesqueleto, desenvolvimento celular e tráfego intracelular (Bork, 1993; Mosavi et al., 2004; Pan et al., 2008; Sedgwick \& Smerdon, 1999; para revisão ver Voth, 2011). Uma das proteínas com domínios de ankirina mais descritas em bactérias intracelulares é a AnkA de Anaplasma phagocytophilum. Ela é responsável pela modulação da transcrição gênica da célula eucariota, já que interage com regiões específicas da cromatina do hospedeiro (Caturegli et al., 2000; Garcia-Garcia et al., 2009; ljdo et al., 2007; Lin et al., 2007; Park et al., 2004). Nossos resultados de microarranjos mostraram que apenas duas CDS (A1G_02840 e A1G_04305), que codificam proteínas com domínios repetidos de anquirinas, foram reprimidas pela alimentação sanguínea. Esse resultado sugere que esses prováveis efetores de $R$. rickettsii atuem em outros órgãos dos carrapatos ou ainda que desempenhem funções apenas em células do hospedeiro vertebrado.

Em virtude da sua importância como efetores do sistema T4SS, analisamos o perfil de outras seis proteínas Anks previamente anotadas no genoma de $R$. rickettsii em glândulas salivares e intestinos de $A$. aureolatum por RT-qPCR microfluídica. Observamos que a alimentação sanguínea não modula as CDS dessas Anks em nenhum dos tecidos e gêneros testados. Por outro lado, três delas (A1G_00070, A1G_01255, A1G_02955) foram significativamente induzidas em glândulas salivares de machos e de fêmeas expostos à elevação da temperatura. As glândulas salivares são um importante sítio de interação entre o carrapato vetor, o hospedeiro vertebrado e o patógeno, uma vez que a saliva produzida nesse órgão é inoculada no hospedeiro vertebrado e pode carrear o patógeno (Nuttall, Labuda, 2003; vide Figura 1). Assim, esses dados de modulação sugerem que estas três proteínas Anks podem estar envolvidas na interação com moléculas do hospedeiro vertebrado, 
propiciando a invasão. Entretanto, futuros estudos funcionais são necessários para esclarecer suas interações com T4SS e seus papéis durante a infecção do carrapato-vetor.

Ainda sob efeito da alimentação sanguínea, observamos a indução de três enzimas antioxidantes (tioredoxina peroxidase 1, glutaredoxina 3 e ferrodoxina) e uma proteína hipotética com domínio de tioredoxina (A1G_00185) (Tabela 3 e Anexo D). A formação de espécies reativas de oxigênio (ROS) e nitrogênio (NOS) em artrópodes hematófagos é consequência da degradação da hemoglobina e liberação do heme (para revisão ver Graça-Souza et al., 2006). Além disso, a produção de ROS e NOS, corresponde a uma defesa imune contra infecções, descrita em todo o reino animal (para revisão ver Dzik, 2010). De fato, já foi reportado que os hemócitos do carrapato Rhipicephalus (Boophilus) microplus produzem ROS quando estimulados por bactérias (Pereira et al., 2001). Dentre os efeitos danosos de ROS, destacam-se a capacidade de oxidar DNA, lipídeos e proteínas, interferindo, assim, nas suas funções fisiológicas (Stroher, Millar, 2012). Estudos também sugerem que o DNA bacteriano seja o alvo primário de ROS quando a concentração de ferro livre está elevada no meio (Park et al., 2005). Dessa maneira, é provável que $R$. rickettsii encontre-se sob estresse oxidativo em carrapatos, tanto em decorrência da resposta imune quanto em decorrência da exposição à alimentação sanguinea. Como os sistemas glutaredoxina (Grx) e tioredoxina (Trx) estão envolvidos na recuperação do proteoma celular ao estado normal após ou durante condições desfavoráveis do ambiente (Stroher, Millar, 2012), é provável que a indução da tioredoxina peroxidase 1 e da glutaredoxina 3 reflita em a tentativa de $R$. rickettsii de se proteger dos efeitos deletérios dos radicais livres em carrapatos alimentados. Assim, esses dados podem ser um indicativo de que esse estresse culmina em uma resposta antioxidativa da bactéria.

Os nossos estudos de transcrição global e tecido-específico demonstram que em $R$. rickettsii a aquisição de sangue reprimiu significativamente três genes codificadores do antígeno de superfície celular (Sca) 8, um gene codificador de Sca10 e outro codificador de Sca13. Em bactérias, proteínas de superfície celular estão envolvidas na interação célula-célula, além de estarem associadas à evasão do sistema imune por modificações estruturais ou ainda à antigenicidade ligada ao sistema imune adaptativo de mamíferos (Erova et al., 2013; Futse et al., 2005; Ojogun et al., 2012; Raja, Natarajaseenivasan, 2013; Walker, 1996). Dessa forma, o 
estudo dessas proteínas pode ser chave para a descoberta de possíveis alvos de bloqueio da infecção. O perfil transcricional de proteínas de superfície de $B$. burgdorferi, já foi descrito como modulado quando associado à presença de sangue em culturas in vitro (Tokarz et al., 2004). Nesse estudo, os genes codificadores da proteína de superfície C (OspC) e da protease Lon, enzima possivelmente relacionada ao remodelamento das proteínas de superfície desta bactéria, foram induzidos. O grupo de proteínas Sca (antígeno de superfície celular) incluem duas importantes proteínas de superfície rOmpA (Sca0) e rOmpB (Sca5) de bactérias do gênero Rickettsia (para revisão ver Blanc et al., 2005). Essas duas proteínas foram previamente relacionadas à adesão e/ou invasão de células de mamíferos (Hillman et al., 2013; Li, Walker, 1998; Uchiyama et al., 2006). Além disso, rOmpA já foi estudada como potencial antígeno vacinal (McDonald et al., 1987; McDonald et al., 1988). Ainda associada à invasão de células hospedeiras, a interação de rOmpB com Ku-70, uma proteína do hospedeiro de $70 \mathrm{kDa}$, foi identificada durante a infecção de $R$. conorii em células Vero (Chan et al., 2009; Martinez et al., 2005).

Nas nossas análises de microarranjo, observamos que rOmpA e rOmpB não foram moduladas por nenhum dos dois estímulos ambientais analisados em órgão totais de fêmeas adultas. Entretanto, quando avaliamos a expressão desses dois genes nas glândulas salivares e intestinos de machos e fêmeas por RT-qPCR microfluídica, identificamos que a elevação de temperatura induziu significativamente a expressão de rOmpA nas glândulas salivares dos carrapatos enquanto rOmpB foi induzida nos intestinos dos carrapatos pela alimentação. Assim, é provável que da mesma maneira que rOmpA esteja associada a interação com moléculas da superfície células do hospedeiro vertebrado, rOmpB possa estar envolvida na interação e invasão do intestino do carrapato-vetor.

Além dos estudos dos efeitos isolados da elevação da temperatura e da alimentação sanguínea sob o perfil transcricional de $R$. rickettsii, avaliamos os efeitos aditivos desses dois estímulos ambientais nas glândulas salivares e intestinos de $A$. aureolatum machos e fêmeas, por RT-qPCR microfluídica. De fato, quando carrapatos infectados no ambiente encontram um hospedeiro vertebrado e iniciam o processo de alimentação, $R$. rickettsii é simultaneamente exposta à elevação da temperatura e componentes do sangue. Interessantemente, identificamos que os efeitos aditivos dos dois estímulos sobre o perfil transcricional de $R$. rickettsii são similares aos efeitos do efeito da alimentação sanguínea 
isoladamente. Importantes fatores de virulência, como os componentes do T4SS (VirB4, VirB8, VirB11 e VirD4), além das enzimas antioxidantes (tioredoxina peroxidase 1 e tioredoxina) também foram induzidas pelos dois estímulos combinados. Estes dados, de maneira geral, reforçam a influência da alimentação sanguínea nos processos de virulência bacteriana, mesmo desencadeando um processo de estresse no microambiente celular.

A transcrição de genes de $R$. rickettsii infectando células BME26 também foi avaliada por RT-qPCR microfluídica. Observamos que todos os genes analisados são expressos in vitro, com valores de Ct (threshold cycle) próximos aos observados em tecidos de carrapatos (Tabela 14). Esse resultado é importante, abrindo a possibilidade do uso de sistemas in vitro para o estudo da transcrição gênica, bem como das proteínas produzidas por $R$. rickettsii. De fato, nos últimos anos, sistemas de cultivo de células in vitro, principalmente de células de vetores e hospedeiros de microrganismos, têm se mostrado uma ferramenta importante para o estudo da biologia dos parasitas e da relação parasita-hospedeiro (para revisão, veja BellSakyi et al., 2007). 


\section{CONCLUSÃO}

A elevação da temperatura em aproximadamente $10^{\circ} \mathrm{C}$ e a exposição aos componentes do sangue do hospedeiro vertebrado simulam alguns dos estímulos ambientais aos quais a bactéria Rickettsia rickettsii é naturalmente exposta em seu carrapato-vetor. Interessantemente, ambos os estímulos foram previamente associados com a reativação da virulência de Rickettsia em carrapatos. Através de análises de expressão gênica, nós demonstramos que os dois estímulos propiciam a proliferação da bactéria em carrapatos, bem como modulam a expressão de conjuntos específicos de genes. No entanto, os componentes do sangue parecem exercer um maior efeito sobre o perfil transcricional de $R$. rickettsii, modulando cinco vezes mais genes que a temperatura. Os efeitos aditivos dos dois estímulos também são muito próximos dos efeitos observados pela alimentação sanguínea somente, reforçando o papel majoritário dos componentes do sangue no remodelamento do perfil de expressão da bactéria.

Os genes modulados que foram identificados neste trabalho, incluindo aqueles codificadores de proteínas hipotéticas, deverão ser funcionalmente caracterizados em futuros trabalhos e podem ser considerados alvos potenciais para o desenvolvimento de uma vacina anti- $R$. rickettsii. Além disso, o cultivo de $R$. rickettsii foi estabelecido com sucesso em um cultivo de células de carrapatos in vitro, onde também foi observada a expressão de diversos genes. Esse resultado é importante, abrindo a possibilidade do uso de sistemas in vitro para o estudo da transcrição gênica, bem como das proteínas produzidas por $R$. rickettsii. 


\section{REFERÊNCIAS*}

Alberdi MP, Nijhof AM, Jongejan F, Bell-Sakyi L. Tick cell culture isolation and growth of Rickettsia raoultii from Dutch Dermacentor reticulatus ticks. Ticks Tick Borne Dis. 2012 Dec;3(5-6):349-54.

Andersen CL, Jensen JL, Orntoft TF. Normalization of real-time quantitative reverse transcription-PCR data: a model-based variance estimation approach to identify genes suited for normalization, applied to bladder and colon cancer data sets. Cancer Res. 2004;64:5245-50.

Angerami RN, Resende MR, Feltrin AF, Katz G, Nascimento EM, Stucchi RS, Silva LJ. Brazilian spotted fever: a case series from an endemic area in southeastern Brazil: clinical aspects. Ann N Y Acad Sci. 2006a Oct;1078:252-4.

Angerami RN, Resende MR, Feltrin AF, Katz G, Nascimento EM, Stucchi RS, Silva LJ. Brazilian spotted fever: a case series from an endemic area in southeastern Brazil: epidemiological aspects. Ann N Y Acad Sci. 2006b Oct;1078:170-2.

Audia JP, Patton MC, Winkler HH. DNA microarray analysis of the heat shock transcriptome of the obligate intracytoplasmic pathogen Rickettsia prowazekii. 2008 Appl Environ Microbiol. 2008 Dec;74(24):7809-12.

Ballman KV, Grill DE, Oberg AL, Therneau TM. Faster cyclic loess: normalizing RNA 529 arrays via linear models. Bioinformatics. 2004;20:2778-86.

Barker SC, Murrell A. Systematics and evolution of ticks with a list of valid genus and species names. Parasitology. 2004;129 Suppl:S15-36. Review.

Barragan A, Hitziger N. Transepithelial migration by Toxoplasma. Subcell. Biochem. 2008;47:198-207.

Barros SL, Madruga CR, Araújo FR, Menk CF, de Almeida MA, Melo EP, Kessler $\mathrm{RH}$. Serological survey of Babesia bovis, Babesia bigemina, and Anaplasma marginale antibodies in cattle from the semi-arid region of the state of Bahia, Brazil, by enzyme-linked immunosorbent assays. Mem Inst Oswaldo Cruz. 2005 Oct;100(6):513-7.

Beckwith J. The Sec-dependent pathway. Res Microbiol. 2013;164:497-504.

Belitskaya-Lévy I, Zeleniuch-Jacquotte A, Russo J, Russo IH, Bordás P, Ahman J, Afanasyeva $Y$, Johansson $R$, Lenner $P$, Li X, de Cicco RL, Peri S, Ross E, Russo PA, Santucci-Pereira J, Sheriff FS, Slifker M, Hallmans G, Toniolo P, Arslan AA. Characterization of a genomic signature of pregnancy identified in the breast. Cancer Prev Res (Phila). 2011 Sep;4(9):1457-64.

\footnotetext{
* De acordo com:

International Committee of Medical Journal Editors. [Internet]. Uniform requirements for manuscripts submitted to Biomedical Journal: sample references. [updated $2011 \mathrm{Jul}$ 15]. Available from: http://www.icmje.org
} 
Bell-Sakyi L, Zweygarth E, Blouin EF, Gould EA, Jongejan F. Tick cell lines: tools for tick and tick-borne disease research. Trends Parasitol. 2007 Sep; 23(9):450-7.

Blanc G, Ngwamidiba M, Ogata H, Fournier PE, Claverie JM. Molecular evolution of rickettsia surface antigens: evidence of positive selection. Mol Biol Evol. 2005;22: 2073-83.

Bork $P$. Hundreds of ankyrin-like repeats in functionally diverse proteins: mobile modules that cross phyla horizontally? Proteins. 1993 Dec;17(4):363-74.

Böse R, Jorgensen WK, Dalgliesh RJ, Friedhoff KT, de Vos AJ. Current state and future trends in the diagnosis of babesiosis. Vet Parasitol. 1995 Mar;57(1-3):61-74. Review.

Brazma A, Hingamp P, Quackenbush J, Sherlock G, Spellman P, Stoeckert C, Aach J, Ansorge W, Ball CA, Causton HC, Gaasterland T, Glenisson P, Holstege FC, Kim IF, Markowitz V, Matese JC, Parkinson H, Robinson A, Sarkans U, Schulze-Kremer S, Stewart J, Taylor R, Vilo J, Vingron M. Minimum information about a microarray experiment (MIAME)-toward standards for microarray data. Nat Genet. 2001 Dec;29(4):365-71.

Burgdorfer W. Ecological and epidemiological considerations of Rock Mountain spotted fever and scrub typhus. pp.33-50 in Biology of Rickettsial Diseases. 1988 vol.1. (D.H. Walker, ed), CRC Inc, Boca Raton, USA.

Calic SB, Barcellos-Rocha CM, Leite RC, Mafra CL, Galvão MA. Old and new human rickettsiosis in Minas Gerais state, Brazil. Ann N Y Acad Sci. 2005 Dec;1063:356-7.

Cardoso LD, Freitas RN, Mafra CL, Neves CV, Figueira FC, Labruna MB, Gennari SM, Walker DH, Galvão MA. Characterization of Rickettsia spp. circulating in a silent peri-urban focus for Brazilian spotted fever in Caratinga, Minas Gerais, Brazil. Cad Saude Publica. 2006 Mar;22(3):495-501.

Caturegli P, Asanovich KM, Walls JJ, Bakken JS, Madigan JE, Popov VL, Dumler JS. ankA: an Ehrlichia phagocytophila group gene encoding a cytoplasmic protein antigen with ankyrin repeats. Infect Immun. 2000 Sep;68(9):5277-83.

Ceraul SM, Dreher-Lesnick SM, Gillespie JJ, Rahman MS, Azad AF. New tick defensin isoform and antimicrobial gene expression in response to Rickettsia montanensis challenge. Infect. Immun. 2007 75:1973-83.

Chan YG, Cardwell MM, Hermanas TM, Uchiyama T, Martinez JJ. Rickettsial outermembrane protein $\mathrm{B}(\mathrm{rOmpB})$ mediates bacterial invasion through $\mathrm{Ku} 70$ in an actin, c-Cbl, clathrin and caveolin 2-dependent manner. Cell Microbiol. 2009;11:629-44.

Chapman, AS, Murphy SM. "Rocky mountain spotted fever in the United States, 1997-2002." Ann N Y Acad Sci. 2006;1078:154-5.

Chen C, Banga S, Mertens K, Weber MM, Gorbaslieva I. Large-scale identification and translocation of type IV secretion substrates by Coxiella burnetii. Proc Natl Acad Sci U S A. 2010; 107: 21755-60. 
Citri A, Pang ZP, Südhof TC, Wernig M, Malenka RC. Comprehensive qPCR profiling of gene expression in single neuronal cells. Nat Protoc. 2011 Dec 22;7(1):118-27.

Colwell DD, Dantas-Torres F, Otranto D. Vector-borne parasitic zoonoses: emerging scenarios and new perspectives. Vet Parasitol. 2011 Nov 24;182(1):14-21.

Concepcion MB, Nelson DR. Expression of spoT in Borrelia burgdorferi during serum starvation. J Bacteriol. 2003 Jan;185(2):444-52.

Conway T, Schoolnik GK. Microarray expression profiling: capturing a genome wide portrait of the transcriptome. Mol. Microbiol. 2003 47:879-89.

Dantas-Torres F. "Rocky Mountain spotted fever." Lancet Infect Dis. 2007 7(11): 724 32.

Dantas-Torres F, Chomel BB, Otranto D. Ticks and tick-borne diseases: a One Health perspective. Trends Parasitol. 2012 Oct;28(10):437-46.

de la Fuente J, Blouin EF, Manzano-Roman R, Naranjo V, Almazán C, Pérez de la Lastra JM, Zivkovic Z, Jongejan F, Kocan KM. Functional genomic studies of tick cells in response to infection with the cattle pathogen, Anaplasma marginale. Genomics. 2007 Dec;90(6):712-22.

de Lemos ER, Alvarenga FB, Cintra ML, Ramos MC, Paddock CD, Ferebee TL, Zaki SR, Ferreira FC, Ravagnani RC, Machado RD, Guimarães MA, Coura JR. Spotted fever in Brazil: a seroepidemiological study and description of clinical cases in an endemic area in the state of São Paulo. Am J Trop Med Hyg. 2001 Oct;65(4):329-34.

Demma LJ, Traeger MS, Nicholson WL, Paddock CD, Blau DM, Eremeeva ME, Dasch GA, Levin ML, Singleton J Jr, Zaki SR, Cheek JE, Swerdlow DL, McQuiston $\mathrm{JH}$. Rocky Mountain spotted fever from an unexpected tick vector in Arizona. N. Engl. J. Med. 2005; 353:587-94.

Dobler G. Zoonotic tick-borne flaviviruses. Vet Microbiol. 2010 Jan 27;140(3-4):2218. Review.

Dreher-Lesnick SM, Ceraul SM, Rahman MS, Azad AF. Genome-wide screen for temperature-regulated genes of the obligate intracellular bacterium, Rickettsia typhi. BMC Microbiol. 2008;8:61.

Dzik JM. The ancestry and cumulative evolution of immune reactions. Acta Biochim Pol. 2010;57:443-66.

Ehrenreich A. DNA microarray technology for the microbiologist: an overview. Appl Microbiol Biotechnol. 2006;73(2):255-73.

Ellison DW, Clark TR, Sturdevant DE, Virtaneva K, Porcella SF, Hackstadt T. Genomic comparison of virulent Rickettsia rickettsii Sheila Smith and avirulent Rickettsia rickettsii lowa. Infect. Immun. 2008;76: 542-50. 
Ellison DW, Clark TR, Sturdevant DE, Virtaneva K, Hackstadt T. Limited transcriptional responses of Rickettsia rickettsii exposed to environmental stimuli. PLoSOne. 2009;4(5): e5612.

Erova TE, Rosenzweig JA, Sha J, Suarez G, Sierra JC, Kirtley ML, van Lier CJ, Telepnev MV, Motin VL, Chopra AK. Evaluation of protective potential of Yersinia pestis outer membrane protein antigens as possible candidates for a new-generation recombinant plague vaccine. Clin Vaccine Immunol. 2013 Feb;20(2):227-38.

Esteves E, Lara FA, Lorenzini DM, Costa GH, Fukuzawa AH, Pressinotti LN, Silva JR, Ferro JA, Kurtti TJ, Munderloh UG, Daffre S. Cellular and molecular characterization of an embryonic cell line (BME26) from the tick Rhipicephalus (Boophilus) microplus. Insect Biochem Mol Biol. 2008 May;38(5):568-80.

Esteves E, Fogaça AC, Maldonado R, Silva FD, Manso PP, Pelajo-Machado M, Valle D, Daffre S. Antimicrobial activity in the tick Rhipicephalus (Boophilus) microplus eggs: Cellular localization and temporal expression of microplusin during oogenesis and embryogenesis. Dev Comp Immunol. 2009 Aug: 33(8):913-9.

Estrada-Peña A, Guglielmone AA, Mangold AJ. The distribution and ecological 'preferences' of the tick Amblyomma cajennense (Acari: Ixodidae), an ectoparasite of humans and other mammals in the Americas. Ann Trop Med Parasitol. 2004 Apr;98(3):283-92.

Estripeaut D, Aramburu MG. "Rocky Mountain spotted fever, Panama." Emerg Infect Dis $2007 ; 13(11): 1763-5$.

Foley JE, Brown RN, Gabriel MW, Henn J, Drazenovich N, Kasten R, Green SL, Chomel BB. Spatial analysis of the exposure of dogs in rural north-coastal California to vector-borne pathogens. Vet Rec. 2007;161(19):653-7.

Fraser CM, Casjens S, Huang WM, Sutton GG, Clayton R, Lathigra R, White O, Ketchum KA, Dodson R, Hickey EK, Gwinn M, Dougherty B, Tomb JF, Fleischmann RD, Richardson D, Peterson J, Kerlavage AR, Quackenbush J, Salzberg S, Hanson $M$, van Vugt R, Palmer N, Adams MD, Gocayne J, Weidman J, Utterback T, Watthey L, McDonald L, Artiach P, Bowman C, Garland S, Fuji C, Cotton MD, Horst K, Roberts K, Hatch B, Smith HO, Venter JC. Genomic sequence of a Lyme disease spirochaete, Borrelia burgdorferi. Nature. 1997 Dec 11;390(6660):580-6.

Fritzen CM, Huang J, Westby K, Freye JD, Dunlap B, Yabsley MJ, Schardein M, Dunn JR, Jones TF, Moncayo AC. Infection prevalences of common tick-borne pathogens in adult lone star ticks (Amblyomma americanum) and American dog ticks (Dermacentor variabilis) in Kentucky. Am J Trop Med Hyg. 2011 Oct;85(4):718-23.

Fuentes LG. 1st case of Rocky Mountain fever in Costa Rica. Central America. Rev Latinoam Microbiol. 1979 Oct-Dec;21(4):167-72.

Futse JE, Brayton KA, Knowles DP Jr, Palmer GH. Structural basis for segmental gene conversion in generation of Anaplasma marginale outer membrane protein variants. Mol Microbiol. 2005 Jul;57(1):212-21. 
Garcia-Garcia JC, Rennoll-Bankert KE, Pelly S, Milstone AM, Dumler JS. Silencing of host cell CYBB gene expression by the nuclear effector AnkA of the intracellular pathogen Anaplasma phagocytophilum. Infect Immun. 2009 Jun;77(6):2385-91.

Garduño RA, Garduño E, Hiltz M, Hoffman PS. Intracellular growth of Legionella pneumophila gives rise to a differentiated form dissimilar to stationary-phase forms. Infect Immun. 2002 Nov;70(11):6273-83.

Gilford $\mathrm{JH}$, Price WH. Virulent-avirulent conversion of Rickettsia rickettsii in vitro. Proc. Natl. Acad. Sci. USA. 1955;41: 870-3.

Gillespie JJ, Ammerman NC, Dreher-Lesnick SM, Rahman MS, Worley MJ. An anomalous type IV secretion system in Rickettsia is evolutionarily conserved. PLoSOne 2009;4: e4833.

Graca-Souza AV, Maya-Monteiro C, Paiva-Silva GO, Braz GR, Paes MC. Adaptations against heme toxicity in blood-feeding arthropods. Insect Biochem Mol Biol 2006;36:322-35.

Greene CE, Breitschwerdt EB. Rocky Mountain spotted fever, murine typhuslike disease, rickettsialpox, typhus, and Q fever. In: Greene C, editor. Infectious diseases of the dog and cat. 2006 3rd ed. Philadelphia: Saunders, Elsevier; p. 232-45.

Guedes E, Leite R, Prata MCA, Pacheco RC, Walker DH, Labruna MB. Detection of Rickettsia rickettsii in the tick Amblyomma cajennense in a new Brazilian spotted fever-endemic area in the state of Minas Gerais. Mem. Instit. Oswaldo Cruz. 2005 100: 841-8.

Habyarimana F, Al-Khodor S, Kalia A, Graham JE, Price CT, Garcia MT, Kwaik YA. Role for the Ankyrin eukaryotic-like genes of Legionella pneumophila in parasitism of protozoan hosts and human macrophages. Environ Microbiol. 2008 Jun;10(6):146074.

Hackstadt T. The biology of rickettsiae. Infect Agents Dis. 1996 Jun;5(3):127-43. Review.

Hajdušek O, Síma R, Ayllón N, Jalovecká M, Perner J, de la Fuente J, Kopá?ek P. Interaction of the tick immune system with transmitted pathogens. Front Cell Infect Microbiol. 2013 Jul 16;3:26.

Han Y, Zhou D, Pang X, Song Y, Zhang L, Bao J, Tong Z, Wang J, Guo Z, Zhai J, Du $Z$, Wang $X$, Zhang $X$, Wang J, Huang $P$, Yang R. Microarray analysis of temperatureinduced transcriptome of Yersinia pestis. Microbiol. Immunol. 2004 48: 791-805.

Hayes SF, Burgdorfer W. Reactivation of Rickettsia rickettsii in Dermacentor andersoni ticks: an ultrastructural analysis. Infect Immun. 1982 Aug;37(2):779-85.

Heinzen RA, Hayes SF, Peacock MG, Hackstadt T. Directional actin polymerization associated with spotted fever group Rickettsia infection of Vero cells. Infect Immun 1993;61: 1926-35. 
Hendrick JP, Hartl FU. Molecular chaperone functions of heat-shock proteins. Annu Rev Biochem 1993;62: 349-84.

Hidalgo M, Orejuela L. "Rocky Mountain spotted fever, Colombia." Emerg Infect Dis 2007 13(7):1058-60.

Hillman RD Jr, Baktash YM, Martinez JJ. OmpA-mediated rickettsial adherence to and invasion of human endothelial cells is dependent upon interaction with integrin. Cell Microbiol. 2013 May;15(5):727-41.

Holman PJ, Ronald NC. A new tick cell line derived from Boophilus microplus. Res Vet Sci. 1980 Nov;29(3):383-7.

Horak IG, Camicas JL, Keirans JE. The Argasidae, Ixodidae and Nuttalliellidae (Acari: Ixodida): a world list of valid tick names. Exp Appl Acarol. 2002 28(1-4):27-54.

Hughes TR, Shoemaker DD. DNA microarrays for expression profiling. Curr. Opin. Chem. Biol. 2001;5:21-5.

Hun L, Cortés X, Taylor L. Molecular characterization of Rickettsia rickettsii isolated from human clinical samples and from the rabbit tick Haemaphysalis leporispalustris collected at different geographic zones in Costa Rica. Am J Trop Med Hyg. 2008 Dec;79(6):899-902.

IJdo JW, Carlson AC, Kennedy EL. Anaplasma phagocytophilum AnkA is tyrosinephosphorylated at EPIYA motifs and recruits SHP-1 during early infection. Cell Microbiol. 2007 May;9(5):1284-96.

Jang JS, Simon VA, Feddersen RM, Rakhshan F, Schultz DA, Zschunke MA, Lingle WL, Kolbert CP, Jen J. Quantitative miRNA expression analysis using fluidigm microfluidics dynamic arrays. BMC Genomics. 2011 Mar 9;12:144.

Johns RH, Sonenshine DE, Hynes WL. Enhancement of OspC expression by Borrelia burgdorferi in the presence of tick hemolymph. FEMS Microbiol Lett. 2000 Dec 1;193(1):137-41.

Jongejan F, Uilenberg G. The global importance of ticks. Parasitology. 2004;129 Suppl:S3-14.

Kang MJ, Yu H, Kim SK, Park SR, Yang I. Quantification of trace-level DNA by realtime whole genome amplification. PLoSOne. 2011;6(12):e28661.

Karim S, Browning R, Ali L, Truhett R. Laboratory-infected Ehrlichia chaffeensis female adult Amblyomma americanum salivary glands reveal differential gene expression. J Med Entomol. 2012 May;49(3):547-54.

Kazmierczak MJ, Mithoe SC, Boor KJ, Wiedmann M. Listeria monocytogenes sigma $B$ regulates stress response and virulence functions. J Bacteriol. 2003 Oct;185(19):5722-34. 
Keirans JE, Durden LA. Invasion: exotic ticks (Acari: Argasidae, Ixodidae) imported into the United States. A review and new records. J Med Entomol. 2001 Nov;38(6):850-61.

Kilpatrick AM, Randolph SE. Drivers, dynamics, and control of emerging vector-borne zoonotic diseases. Lancet. 2012 Dec 1;380(9857):1946-55.

Klompen JS, Black WC 4th, Keirans JE, Oliver JH Jr. Evolution of ticks. Annu Rev Entomol. 1996 ;41:141-61. Review.

Kreil DP, Russell RR, Russell S. Microarray oligonucleotide probes. Methods Enzymol. 2006 410: 73-98. Review.

Kumar P, Dezso Z, Mackenzie C, Oestreicher J, Agoulnik S, Byrne M, Bernier F, Yanagimachi M, Aoshima K, Oda Y. Circulating miRNA Biomarkers for Alzheimer's Disease. PLoSOne. 2013 Jul 29;8(7):e69807.

Kurtti TJ, Munderloh UG, Krueger DE, Johnson RC, Schwan TG. Adhesion to and invasion of cultured tick (Acarina: Ixodidae) cells by Borrelia burgdorferi (Spirochaetales: Spirochaetaceae) and maintenance of infectivity. J Med Entomol. 1993 May;30(3):586-96.

La MV, François P, Rovery C, Robineau S, Barbry P, Schrenzel J, Raoult D, Renesto $P$. Development of a method for recovering rickettsial RNA from infected cells to analyze gene expression profiling of obligate intracellular bacteria. J Microbiol Methods. 2007 71(3):292-7.

Labruna MB, Horta MC, Aguiar DM, Cavalcante GT, Pinter A, Gennari SM, Camargo LMA. Prevalence of Rickettsia infection in dogs from the urban and rural areas of Monte Negro Municipality, western Amazon, Brazil. Vector Borne Zoonotic Dis 2007 7: 249-55.

Labruna MB, Ogrzewalska M, Martins, TF, Pinter A, Horta MC. Comparative susceptibility of larval stages of Amblyomma aureolatum, Amblyomma cajennense, and Rhipicephalus sanguineus to infection by Rickettsia rickettsii. Journal of Medical Entomology. 2008 45(6): 1156-9.

Labruna MB. Ecology of rickettsia in South America. Ann N Y Acad Sci. 2009 May;1166:156-66.

Labruna MB, Ogrzewalska M, Soares JF, Martins TF, Soares HS, Moraes-Filho J, Nieri-Bastos FA, Almeida AP, Pinter A. Experimental Infection of Amblyomma aureolatum ticks with Rickettsia rickettsii. Emerging Infectious Diseases. 201117 (5): 829-34.

Lasala PR, Holbrook M. Tick-borne flaviviruses. Clin Lab Med. 2010 Mar;30(1):22135.

Latif AA, Putterill JF, de Klerk DG, Pienaar R, Mans BJ. Nuttalliella namaqua (Ixodoidea: Nuttalliellidae): first description of the male, immature stages and redescription of the female. PLoSOne 2012 7(7):e41651. 
Lawson JN, Johnston SA. Amplification of sense-stranded prokaryotic RNA. DNA Cell Biol. 2006 Nov;25(11):627-34.

Leroy Q, Raoult D. Review of microarray studies for host-intracellular pathogen interactions. J. Microb Methods 2010;81(2):81-95.

$\mathrm{Li} \mathrm{H}$, Walker $\mathrm{DH}$. rOmpA is a critical protein for the adhesion of Rickettsia rickettsii to host cells. Microb Pathog 1998;24:289-98.

Lin M, den Dulk-Ras A, Hooykaas PJ, Rikihisa Y. Anaplasma phagocytophilum AnkA secreted by type IV secretion system is tyrosine phosphorylated by Abl-1 to facilitate infection. Cell Microbiol. 2007 Nov;9(11):2644-57.

Livak KJ, Schmittgen TD. Analysis of relative gene expression data using real-time quantitative PCR and the 2(-Delta Delta C(T)) Method. Methods 2001;25: 402-408.

Lucchini S, Thompson A, Hinton JC. Microarrays for microbiologists. Microbiology. 2001 Jun;147(6):1403-14.

Macaluso KR, Mulenga A, Simser JA, Azad AF. Differential expression of genes in uninfected and rickettsia-infected Dermacentor variabilis ticks as assessed by differential-display PCR. Infect. Immun. 2003;71:6165-70.

Macaluso KR, Mulenga A, Simser JA, Azad AF. Characterization of Dermacentor variabilis molecules associated with rickettsial infection. Ann. N. Y. Acad. Sci. 2006; 1078: 384-88.

Mans BJ, Neitz AW. Adaptation of ticks to a blood-feeding environment: evolution from a functional perspective. Insect Biochem Mol Biol. 2004 Jan;34(1):1-17. Review.

Mans BJ, de Klerk D, Pienaar R, de Castro MH, Latif AA. The mitochondrial genomes of Nuttalliella namaqua (Ixodoidea: Nuttalliellidae) and Argas africolumbae (Ixodoidae: Argasidae): estimation of divergence dates for the major tick lineages and reconstruction of ancestral blood-feeding characters. PLoSOne 2012 7(11):e49461.

Martinez JJ, Seveau S, Veiga E, Matsuyama S, Cossart P. Ku70, a component of DNA-dependent protein kinase, is a mammalian receptor for Rickettsia conorii. Cell. 2005 Dec 16;123(6):1013-23.

McDade JE, Newhouse VF. Natural history of Rickettsia rickettsii. Annu Rev Microbiol. 1986;40:287-309.

McDonald GA, Anacker RL, Garjian K. Cloned gene of Rickettsia rickettsii surface antigen: candidate vaccine for Rocky Mountain spotted fever. Science. 1987 Jan $2 ; 235(4784): 83-5$.

McDonald GA, Anacker RL, Mann RE, Milch LJ. Protection of guinea pigs from experimental Rocky Mountain spotted fever with a cloned antigen of Rickettsia rickettsii. J Infect Dis. 1988 Jul;158(1):228-31. 
McNally KL, Mitzel DN, Anderson JM, Ribeiro JM, Valenzuela JG, Myers TG, Godinez A, Wolfinbarger JB, Best SM, Bloom ME. Differential salivary gland transcript expression profile in Ixodes scapularis nymphs upon feeding or flavivirus infection. Ticks Tick Borne Dis. 2012 Feb;3(1):18-26.

Mosavi LK, Cammett TJ, Desrosiers DC, Peng ZY. The ankyrin repeat as molecular architecture for protein recognition. Protein Sci 2004 13: 1435-48.

Mulenga A, Macaluso KR, Simser JA, Azad AF. Dynamics of Rickettsia-tick interactions: identification and characterization of differentially expressed mRNAs in uninfected and infected Dermacentor variabilis. Insect Mol. Biol. 2003;12:185-93.

Munderloh UG, Jauron SD, Fingerle V, Leitritz L, Hayes SF, Hautman JM, Nelson CM, Huberty BW, Kurtti TJ, Ahlstrand GG, Greig B, Mellencamp MA, Goodman JL. Invasion and intracellular development of the human granulocytic ehrlichiosis agent in tick cell culture. J Clin Microbiol. 1999 Aug;37(8):2518-24.

Narasimhan S, Santiago F, Koski RA, Brei B, Anderson JF, Fish D, Fikrig E. Examination of the Borrelia burgdorferi transcriptome in Ixodes scapularis during feeding. J Bacteriol. 2002 Jun;184(11):3122-5.

Nava S, Guglielmone AA, Mangold AJ. An overview of systematics and evolution of ticks. Front Biosci 2009 Jan 1;14:2857-77. Review.

Nene V, Lee D, Kang'a S, Skilton R, Shah T, de Villiers E, Mwaura S, Taylor D, Quackenbush J, Bishop R. Genes transcribed in the salivary glands of female Rhipicephalus appendiculatus ticks infected with Theileria parva. Insect Biochem Mol Biol. 2004 Oct;34(10):1117-28.

$\mathrm{Ng} \mathrm{SK}$, Tan SH, Sundararajan VS. On combining multiple microarray studies for improved functional classification by whole-dataset feature selection. Genome Inform. 2003;14:44-53.

Nicholson WL, Allen K E. The increasing recognition of rickettsial pathogens in dogs and people. Trends in Parasitology 2010;26(4): 205-12.

Niebylski ML, Peacock MG, Schwan ETG. Lethal effect of Rickettsia rickettsii on its tick vector (Dermacentor andersoni). App. Environm. Microbiol. 1999;65:773-338.

Nuttall PA, Labuda M. Dynamics of infection in tick vectors and at the tick-host interface. Adv Virus Res. 2003;60:233-72. Review.

Ogrzewalska M, Saraiva DG, Moraes-Filho J, Martins TF, Costa FB, Pinter A, Labruna MB. Epidemiology of Brazilian spotted fever in the Atlantic Forest, state of São Paulo, Brazil. Parasitology. 2012 Sep;139(10):1283-300.

Ojaimi C, Brooks C, Casjens S, Rosa P, Elias A, Barbour A, Jasinskas A, Benach J, Katona L, Radolf J, Caimano M, Skare J, Swingle K, Akins D, Schwartz I. Profiling of temperature-induced changes in Borrelia burgdorferi gene expression by using whole genome arrays. Infect. Immun. 200;71:1689-1705. 
Ojogun N, Kahlon A, Ragland SA, Troese MJ, Mastronunzio JE, Walker NJ, Viebrock L, Thomas RJ, Borjesson DL, Fikrig E, Carlyon JA. Anaplasma phagocytophilum outer membrane protein $A$ interacts with sialylated glycoproteins to promote infection of mammalian host cells. Infect Immun. 2012 Nov;80(11):3748-60.

Paddock CD, Fernandez S, Echenique GA, Sumner JW, Reeves WK, Zaki SR, Remondegui CE. Rocky Mountain spotted fever in Argentina. Am J Trop Med Hyg. 2008 Apr;78(4):687-92.

Pan X, Luhrmann A, Satoh A, Laskowski-Arce MA, Roy CR Ankyrin repeat proteins comprise a diverse family of bacterial type IV effectors. Science. 2008;320: 1651- 4.

Park J, Kim KJ, Choi KS, Grab DJ, Dumler JS. Anaplasma phagocytophilum AnkA binds to granulocyte DNA and nuclear proteins. Cell Microbiol. 2004 Aug;6(8):74351.

Park S, You X, Imlay JA Substantial DNA damage from submicromolar intracellular hydrogen peroxide detected in Hpx- mutants of Escherichia coli. Proc Natl Acad Sci USA. 2005 102: 9317-9322.

Parola P, Paddock CD, Raoult D. Tick-borne rickettsioses around the world: emerging diseases challenging old concepts. Clin. Microbiol. Rev. 2005;18: 719-56.

Parola P, Raoult D. Tropical rickettsioses. Clin Dermatol. 2006 May-Jun;24(3):191200. Review.

Pashalidis S, Moreira LM, Zaini PA, Campanharo JC, Alves LM, L. Ciapina P, R. Vêncio RZ, Lemos EG, da Silva AM, da Silva AC. Whole-genome expression profiling of Xylella fastidiosa in response to growth on glucose. Omics. 2005;9: 77-90.

Patel R, Tsan A, Tam R, Desai R, Schoenbrunner N. Mutation Scanning Using MUTMAP, a High-Throughput, Microfluidic Chip-Based, Multi- Analyte Panel. PLoSOne. 2012 7(12): e51153.

Pereira LS, Oliveira PL, Barja-Fidalgo C, Daffre S. Production of reactive oxygen species by hemocytes from the cattle tick Boophilus microplus. Exp Parasitol. 2001;99: 66-72.

Peterson DR. Constructing multivariate prognostic gene signatures with censored survival data. Methods Mol Biol. 2013;972:85-101.

Piesman J, Eisen L. Prevention of tick-borne diseases. Annu Rev Entomol. 2008;53:323-43.

Piesman J, Zeidner NS, Schneider BS. Dynamic changes in Borrelia burgdorferi populations in Ixodes scapularis (Acari: Ixodidae) during transmission: studies at the mRNA level. Vector Borne Zoonotic Dis. 2003 Fall;3(3):125-32.

Pinter A, Labruna MB. Isolation of Rickettsia rickettsii and Rickettsia bellii in cell culture from the tick Amblyomma aureolatum in Brazil. Ann N Y Acad Sci. 2006;1078: 523-9. 
Policastro PF, Munderloh UG, Fischer ER, Hackstadt T. Rickettsia rickettsii growth and temperature-inducible protein expression in embryonic tick cell lines. J. Med. Microbiol. 1997;46: 839-45.

Pornwiroon W, Pourciau SS, Foil LD, Macaluso KR. Rickettsia felis from cat fleas: isolation and culture in a tick-derived cell line. Appl Environ Microbiol. 2006 Aug: 72(8):5589-95.

Rahman MS, Gillespie JJ, Kaur SJ, Sears KT, Ceraul SM. Rickettsia typhi Possesses Phospholipas e A2 Enzymes that Are Involved in Infection of Host Cells. PLoS Pathog. 2013;9: e1003399.

Rahman MS, Simser JA, Macaluso KR, Azad AF. Functional analysis of secA homologues from rickettsiae. Microbiology. 2005;151: 589-96.

Raja V, Natarajaseenivasan K. Pathogenic, diagnostic and vaccine potential of leptospiral outer membrane proteins (OMPs). Crit Rev Microbiol. 2013 May 21.

Renesto P, Rovery C, Schrenzel J, Leroy Q, Huyghe A, Li W, Lepidi H, François P, Raoult D. Rickettsia conorii transcriptional response within inoculation eschar. PLoSOne. 2008;3(11):e3681.

Reynolds MA, Chaves SS, Harpaz R, Seward JF. The impact of the varicella vaccination program on herpes zoster epidemiology in the United States: a review. J. Infect. Dis 2008;1:S224-7.

Rikihisa Y, Lin M. Anaplasma phagocytophilum and Ehrlichia chaffeensis type IV secretion and Ank proteins. Curr Opin Microbiol. 2010;13: 59-66.

Ripoll CM, Remondegui CE, Ordonez G, Arazamendi R, Fusaro H, Hyman MJ, Paddock CD, Zaki SR, Olson JG, Santos-Buch CA. Evidence of rickettsial spotted fever and ehrlichial infections in a subtropical territory of Jujuy, Argentina. Am J Trop Med Hyg. 1999 Aug;61(2):350-4.

Rosa RD, de Lorgeril J, Tailliez P, Bruno R, Piquemal D, Bachère $E$. A hemocyte gene expression signature correlated with predictive capacity of oysters to survive Vibrio infections. BMC Genomics. 2012 Jun 18;13:252.

Rovery C, Renesto P, Crapoulet N, Matsumoto K, Parola P, Ogata H, Raoult D. Transcriptional response of Rickettsia conorii exposed to temperature variation and stress starvation. Res. Microbiol. 2005 156: 211-18.

Rozen S, Skaletsky H Primer3 on the WWW for general users and for biologist programmers. Methods Mol Biol. 2000;132: 365-86.

Rudenko N, Golovchenko M, Edwards MJ, Grubhoffer L. Differential expression of Ixodes ricinus tick genes induced by blood feeding or Borrelia burgdorferi infection. J Med Entomol. 2005 Jan;42(1):36-41.

Sangioni LA, Horta MC, Vianna MCB, Gennari SM, Soares RS, Galvão MAM, Schumaker TTS, Ferreira F, Vidotto O, Labruna MB. Rickettsial infection in animals and Brazilian spotted fever endemicity. Emerging Infec. Dis. 2005;11: 265-70. 
Schnittger L, Rodriguez AE, Florin-Christensen M, Morrison DA. Babesia: a world emerging. Infect Genet Evol. 2012 Dec;12(8):1788-809. Review.

Schoolnik GK. Functional and comparative genomics of pathogenic bacteria. Curr. Op. Microbiol. 2002;5: 20-6.

Schulze A \& Downward J. Navigating gene expression using microarrays - a technology review. Nature Cell Biol. 2001;3: E190-5.

Sedgwick SG, Smerdon SJ. The ankyrin repeat: a diversity of interactions on a common structural framework. Trends Biochem Sci. 1999 Aug;24(8):311-6. Review.

Shi M, Beauchamp RD, Zhang B. A network-based gene expression signature informs prognosis and treatment for colorectal cancer patients. PLoSOne. 2012 7(7):e41292.

Sigal LH, Zahradnik JM, Lavin P, Patella SJ, Bryant G, Haselby R, Hilton E, Kunkel M, Adler-Klein D, Doherty T, Evans J, Molloy PJ, Seidner AL, Sabetta JR, Simon HJ, Klempner MS, Mays J, Marks D, Malawista SE. A vaccine consisting of recombinant Borrelia burgdorferi outer-surface protein A to prevent Lyme disease. Recombinant Outer-Surface Protein A Lyme Disease Vaccine Study Consortium. N Engl J Med. 1998 Jul 23;339(4):216-22.

Soares JF, Soares HS, Barbieri AM, Labruna MB. Experimental infection of the tick Amblyomma cajennense, Cayenne tick, with Rickettsia rickettsii, the agent of Rocky Mountain spotted fever. Med Vet Entomol. 2012 Jun; 26(2):139-51.

Souza CE, Moraes-Filho J, Ogrzewalska M, Uchoa FC, Horta MC, Souza SS, Borba RC, Labruna MB. Experimental infection of capybaras Hydrochoerus hydrochaeris by Rickettsia rickettsii and evaluation of the transmission of the infection to ticks Amblyomma cajennense. Vet Parasitol. 2009 Apr 6;161(1-2):116-21.

Spencer RR, Parker RR. Rocky Mountain spotted fever: infectivity of fasting and recently fed ticks. Public Health Reports. 1923;38: 333-9.

Stevenson B, von Lackum K, Riley SP, Cooley AE, Woodman ME, Bykowski T. Evolving models of Lyme disease spirochete gene regulation. Wien Klin Wochenschr. 2006 Nov;118(21-22):643-52. Review.

Stewart GR, Wernisch L, Stabler R, Mangan JA, Hinds J, Laing KG, Young DB, Butcher PD. Dissection of the heat-shock response in Mycobacterium tuberculosis using mutants and microarrays. Microbiology. 2002 148(10):3129-3138.

Stroher E, Millar AH. The biological roles of glutaredoxins. Biochem J. 2012;446: 333-48.

Suarez CE, Noh S. Emerging perspectives in the research of bovine babesiosis and anaplasmosis. Vet Parasitol. 2011 Aug 4;180(1-2):109-25. 
Sunyakumthorn P, Petchampai N, Kearney MT, Sonenshine DE, Macaluso KR. Molecular characterization and tissue-specific gene expression of Dermacentor variabilis $\alpha$-catenin in response to rickettsial infection. Insect Mol Biol. 2012 Apr;21(2):197-204.

Szabó MP, Pinter A, Labruna MB. Ecology, biology and distribution of spotted-fever tick vectors in Brazil. Front Cell Infect Microbiol. 2013 Jul 12;3:27.

Tokarz R, Anderton JM, Katona LI, Benach JL. Combined effects of blood and temperature shift on Borrelia burgdorferi gene expression as determined by whole genome DNA Array. Infect. Immun. 2004;72:5419-32.

Uchiyama T. Tropism and pathogenicity of rickettsiae. Front Microbiol. 2012;3: 230.

Uchiyama T, Kawano H, Kusuhara $\mathrm{Y}$. The major outer membrane protein rOmpB of spotted fever group rickettsiae functions in the rickettsial adherence to and invasion of Vero cells. Microbes Infect. 2006;8:801-9.

van der Veen S, Hain T, Wouters JA, Hossain H, de Vos WM, Abee T, Chakraborty $\mathrm{T}$, Wells-Bennik $\mathrm{MH}$. The heat-shock response of Listeria monocytogenes comprises genes involved in heat shock, cell division, cell wall synthesis, and the SOS response. Microbiology. 2007;153(10):3593-607.

Vieira AML, Souza C E, Labruna MB, Mayo R C, Souza SSL, Camargo-Neves VLF. Manual de Vigilância Acarológica, Estado de São Paulo. Secretaria da Saúde do Estado de São Paulo, Brasil. 2004;62pp.

Voth DE. ThANKs for the repeat: Intracellular pathogens exploit a common eukaryotic domain. Cell Logist. 2011;1: 128-132.

Voth DE, Broederdorf LJ, Graham JG. Bacterial 570 Type IV secretion systems: versatile virulence machines. Future Microbiol. 2012;7:241-57.

Walker DH, Feng HM, Popov VL. Rickettsial phospholipase A2 as a pathogenic mechanism in a model of cell injury by typhus and spotted fever group rickettsiae. Am J Trop Med Hyg. 2001;65:936-42.

Walker, DH. Rocky Mountain spotted fever: a disease in need of microbiological concern. Clin. Microbiol. Rev. 1989;2(3): 227-40.

Walker DH. Rickettsiae. n: Baron S, editor. Medical Microbiology. 4th edition. Galveston (TX): University of Texas Medical Branch at Galveston. 1996 Chapter 38.

Weiss E. The biology of rickettsiae. Annu Rev Microbiol. 1982;36:345-70. Review.

Wike DA, Burgdorfer W. Plaque formation in tissue cultures by Rickettsia rickettsi isolated directly from whole blood and tick hemolymph. Infect Immun. 1972 Nov;6(5):736-8.

Winkler HH. Rickettsial permeability. An ADP-ATP transport system. J Biol Chem. 1976;251: 389-96. 
Winkler HH. Rickettsia species (as organisms). Annu Rev Microbiol. 1990;44:131-53.

Wolbach SB. Studies on Rocky Mountain spotted Fever. J Med Res. 1919 Nov;41(1):1-198.41.

Zaini PA, Fogaça AC, Lupo FG, Nakaya HI, Vêncio RZ, da Silva AM. The iron stimulon of Xylella fastidiosa includes genes for type IV pilus and colicin V-like bacteriocins. J Bacteriol. 2008;190(7):2368-78.

Zavala-Castro JE, Zavala-Velázquez JE, Walker DH, Ruiz Arcila EE, Laviada-Molina $\mathrm{H}$, Olano JP, Ruiz-Sosa JA, Small MA, Dzul-Rosado KR. Fatal human infection with Rickettsia rickettsii, Yucatán, Mexico. Emerg Infect Dis. 2006 Apr;12(4):672-4.

Zivkovic Z, Blouin EF, Manzano-Roman R, Almazán C, Naranjo V, Massung RF, Jongejan F, Kocan KM, de la Fuente J. Anaplasma phagocytophilum and Anaplasma marginale elicit different gene expression responses in cultured tick cells. Comp Funct Genomics. 2009;705034.

Zivkovic Z, Esteves E, Almazán C, Daffre S, Nijhof AM, Kocan KM, Jongejan F, de la Fuente J. Differential expression of genes in salivary glands of male Rhipicephalus (Boophilus) microplus in response to infection with Anaplasma marginale. BMC Genomics. 2010 Mar 18;11:186. 


\section{APÊNDICES}

\section{APÊNDICE A - Oligonucleotídeos utilizados na validação dos dados de expressão gênica de $R$. rickettsii obtidos nos}

microarranjos.

\begin{tabular}{|c|c|c|c|}
\hline CDS & Gene alvo & Oligonucleotídeo senso & Oligonucleotídeo antissenso \\
\hline ref|NC_009882.1_652833-655895 & Antígeno de superfície & TAACCAACCACTGCAACCTG & TTGCATGCTGCCTGATAAAG \\
\hline ref|NC_009882.1_:1249026-1247194 & Proteína de reparo e emparelhamento de DNA & CCTTACTGCGTCAAATGGAAA & CGTCCAAATAAGCGTTCGAT \\
\hline ref|NC_009882.1_:1250262-1250714 & Proteína hipotética A1G_07480 & TTGGAGAAGTAGGTGATTTTGG & TGGTAAACTCCGCTACCTTTTT \\
\hline ref|NC_009882.1_:991314-992378 & Proteína de resistência a biciclomicina & GGGATATCATCGGTTGCAG & AGGGCAATAGTGCCGTTTA \\
\hline ref|NC_009882.1: $: 487702-488622$ & Recombinase XerD tirosina sítio específico & CGCGTTTAATCCGGTTCTTA & TTGAGAGCAATGTTCAAGTAACG \\
\hline ref|NC_009882.1_c944176-943964 & Proteína like de choque térmico & TTTGTACACAAATCAGCCGTAGA & CAGCATAGGCTTTTCCTTGC \\
\hline ref|NC_009882.1_:524000-524968 & Proteína hipotética A1G_03000 & GCTTGGTGAATCGACCTTATT & GATAAAGGCGTATTTGCCTCA \\
\hline ref|NC_009882.1_:45976-46317 & Antígeno-like de superfície Sca10 & CCGGGACTACATGCTTCTGT & TGCTGCTAATTGTAGTGTTCTCAA \\
\hline ref|NC_009882.1_:c901984-901727 & Chaperonina GroEL & TTTTGGAGCCATCCATTACC & GGTCGGCGACTATCCATATCT \\
\hline ref|NC_009882.1_:134020-134307 & Proteína VirB3 do sistema de secreção tipo IV & CGCCGATGATATTTGGAGTAA & CAAAGCAGCTGCAATGAATAA \\
\hline ref|NC_009882.1_:269892-269554 & Ferredoxina & CACCGGGGTTAATAGAATGG & ATTTATCGGCATCAGGCAAA \\
\hline ref|NC_009882.1_:275087-275395 & Glutarredoxina 3 & AATATGCATGTTGGCGGTTG & CAGCAGGTGCAGTCGTCTT \\
\hline ref|NC_009882.1_:3990274-389576 & Proteína virB8 & ACTTTTGAATCACTGGCAAAAA & GGCATATCAGGTGATGTATTGG \\
\hline ref|NC_009882.1_:392342-393790 & Proteína virB10 & CGCCGGTCTTACCTCCTACT & TGCATCGCTCTCAACTAACG \\
\hline \begin{tabular}{|r|} 
ref|NC_009882.1_:393787-394791 \\
\end{tabular} & Proteína virB11 & GAGGCCTGTTTGCGTTTAAG & TGAACCGGGATGACCTGTAT \\
\hline ref|NC_009882.1_:1051294-1051470 & Proteína hipotética A1G_06350 & GCAAGGTGCAGGTCAAGAT & AGTTAGCTGAGCTGTGAGGACA \\
\hline
\end{tabular}


APÊNDICE B - Oligonucleotídeos utilizados na validação dos dados de expressão gênica de $R$. rickettsii obtidos nos microarranjos.

\begin{tabular}{|c|c|c|c|}
\hline CDS & Gene alvo & Oligonucleotídeo senso & Oligonucleotídeo antissenso \\
\hline \multirow{2}{*}{ ref|NC_009882.1_:C373645-373484 } & \multirow{2}{*}{ Proteína de superfície externa A (ompA) } & AGATTTCGGTACGTGGGCTA & CCGACAGTACTGCTGGTTGA \\
\hline & & GGTACGTGGGCTAGTCCTTTT & CCGACAGTACTGCTGGTTGA \\
\hline \multirow{2}{*}{ ref|NC_009882.1_:c1007464-1002500 } & \multirow{2}{*}{ Proteína de superfície externa B (ompB) } & TGGTGCAGGATTACAAGGAA & AGTAGTACCGCCGCCTAAAA \\
\hline & & GAACACATGCTGCCGAGTTA & CCGACAAGAGCAGTTTGGTT \\
\hline ref|NC_009882.1 : : c819688-816968 & Componente A da via de secreção de proteína dependente de Sec & AAACGCCAAATTTCATGAGC & TACCCCGTCCTGCCATATTA \\
\hline ref|NC_009882.1:97701-98159 & Componente $\mathrm{B}$ da via de secreção de proteína dependente de Sec & CCGCATATTTCCGTTAATGC & ATCAATTTGAGGGCGTTGAT \\
\hline ref|NC_009882.1_:832661-834217 & Componente $\mathrm{D}$ da via de secreção de proteína dependente de Sec & ATCTGCGTTTGGCCACTATCC & CAACGGCAAAACCTTTTGATT \\
\hline ref|NC_009882.1:177150-177350 & Componente $\mathrm{E}$ da via de secreção de proteína dependente de Sec & TGTTGCTTCAACGTTAGTAGTGG & GCCGATATTAAGCAAAAGCTG \\
\hline ref|NC_009882.1:156281-157207 & Preproteína translocase subunidade F & GGGGCTATGGCGATGTTATT & GTCATGCACTAAGGCGATCA \\
\hline ref|NC_009882.1_c922200-920899 & Preproteína translocase subunidade $\mathrm{Y}$ & AATTTATGGAGGCGAAGCAA & ATTAGCAAGCGTAGCAGGAAA \\
\hline ref|NC_009882.1_:262509-262940 & Antígeno-like de superfície Sca8 & GCTCCTGTACTTAACGGTGCT & TGCTCGTTACGTCCTGTTTC \\
\hline ref|NC 009882.1:45976-46317 & Antígeno-like de superfície Sca10 & CCGGGACTACATGCTTCTGT & TGCTGCTAATTGTAGTGTTCTCAA \\
\hline ref|NC_009882.1_:c1153524-1153240 & Antígeno-like de superfície Sca13 & GCAGTACTTCAAAAGTGGGTGAT & TCCTTAAATTTTTATGTCGCCAAC \\
\hline \multirow{2}{*}{ ref|NC_009882.1_:134020-134307 } & \multirow{2}{*}{ Proteína VirB3 componente do sistema de secreção tipo IV } & GGTTAACTAGACCGCCGATG & TCATAATGCCGTTATTCCAAA \\
\hline & & CGCCGATGATATTTGGAGTAA & CAAAGCAGCTGCAATGAATAA \\
\hline \multirow{2}{*}{ ref|NC_009882.1_:394925-396700 } & \multirow{2}{*}{ Proteína VirD4 componente do sistema de secreção tipo IV } & TCCGCCTATAAAATCGCGTA & TGCCCTAGGGTCAAAAGGTA \\
\hline & & AGATGCAAGCTGGGCTAATC & GAACCCGTCTGCAACAAAAT \\
\hline \multirow{2}{*}{ |ref|NC_009882.1_:C390274-389576 } & \multirow{2}{*}{ Proteína VirB8 componente do sistema de secreção tipo IV } & ACTTTTGAATCACTGGCAAAAA & GGCATATCAGGTGATGTATTGG \\
\hline & & ATCCGGCGAATATTTTATTGA & TCGTGCATATTAAAAGCAGAAGA \\
\hline \multirow{2}{*}{ ref|NC_009882.1_:391686-392159 } & \multirow{2}{*}{ Proteína precursora VirB9 componente do sistema de secreção tipo IV } & TGCATTTTGGCTTTCAATCA & TGCCAAAGGAGTTATTTTCCA \\
\hline & & TTAGTTTTGCATTTTGGCTTTC & TTTGCCAAAGGAGTTATTTTCC \\
\hline \multirow{2}{*}{ ref|NC_009882.1_:392342-393790 } & \multirow{2}{*}{ Proteína VirB10 componente do sistema de secreção tipo IV } & CGCCGGTCTTACCTCCTACT & TGCATCGCTCTCAACTAACG \\
\hline & & CCGGCTTTAATATAGGGCTTG & CAATTGTTTTGCCGTAGCAC \\
\hline \multirow{2}{*}{ ref|NC_009882.1_:393787-394791 } & \multirow{2}{*}{ Proteína ATPase VirB11 do sistema de secreção tipo IV } & GAGGCCTGTTTGCGTTTAAG & TGAACCGGGATGACCTGTAT \\
\hline & & CGCTCAATCTACCGAACAGA & CCTATCTCACAAGCAGGAGGA \\
\hline \multirow{2}{*}{ ref|NC_009882.1_:1107497-1109929 } & \multirow{2}{*}{ Proteína precursora VirB4 componente do sistema de secreção tipo IV } & TACTGCGAACCGAGAAAGG & AATACGGTTTTTGCCGGTTT \\
\hline & & ACATGGCATTACCTCAGAGAAA & TGTAGCCAAAAAGCAAAATCA \\
\hline ref|NC_009882.1_:c968241-966715 & Metionil tRNA sintetase & GCGTTTTCATGCCGTCTATT & AATTTTCTGCCCATCATTCG \\
\hline ref|NC_009882.1_:575078-576217 & Subunidade beta da DNA polimerase III & GGCAACGCAAAAGAGGTTA & TCCAAATATTGCGGGTTAAA \\
\hline ref|NC_010263.2_:c856717-858162 & Proteina RickA de ativação do complexo Arp2/3 & GGAAAATCAACCACGTCCTTC & TGCAACCGGTTTTCCTGTAT \\
\hline ref|NC_009882.1_:1028222-1028911 & Subunidade epsilon da DNA polimerase III & ACAACAAGGTCATCGAATCGT & AGCCTCAAACGGCATATCTC \\
\hline
\end{tabular}


APÊNDICE B - Continuação.

\begin{tabular}{|c|c|c|c|}
\hline CDS & Gene alvo & Oligonucleotídeo senso & Oligonucleotídeo antissenso \\
\hline ref|NC_009882.1_:832252-832677 & Preproteína translocase subunidade YajC & GTGCCTGCAGAAACAAATTCT & TCGTGTTTCTTGTGGACGTAA \\
\hline ref|NC_009882.1_:859725-861197 & Precursor b1 de patatin & CGATTTTACTGGAGGGACCA & TTGCGCTGCACTGAATAAAG \\
\hline ref|NC_009882.1_:c248307-246424 & Chaperona molecular DnaK & ATTGAAACTCTTGGCGGTGT & TTACGGCATGCTGGTTATCA \\
\hline ref|NC_009882.1_: c1181808-1181458 & Ferredoxina & CACCGGGGTTAATAGAATGG & ATTTATCGGCATCAGGCAAA \\
\hline ref|NC_009882.1_:275087-275395 & Glutarredoxina 3 & AATATGCATGTTGGCGGTTG & CAGCAGGTGCAGTCGTCTT \\
\hline ref|NC_009882.1:c450224-449622 & Tiorredoxina peroxidase 1 & ATTTGTCGGCAAAACTGCTC & TATCCCCTGCAGCATAATTG \\
\hline ref|NC_009882.1_:361975-362622 & Proteína B exportadora de heme & TGGAAGACGGAAGCTTAGAGT & AACAAAAACCAGCCCTATCG \\
\hline ref|NC_009882.1_:c901984-901727 & Chaperonina GroEL & TTTTGGAGCCATCCATTACC & GGTCGGCGACTATCCATATCT \\
\hline ref|NC_009882.1_c944176-943964 & Proteína de choque térmico-like & TTTGTACACAAATCAGCCGTAGA & CAGCATAGGCTTTTCCTTGC \\
\hline ref|NC_009882.1 :652833-655895 & Antígeno de superfície & TAACCAACCACTGCAACCTG & TTGCATGCTGCCTGATAAAG \\
\hline ref|NC_009882.1_:c803667-803269 & Proteína FtsL de divisão celular & ACTTTTTGCGGCTAGATTGG & TATATTTGGCCCTAACGGATCTT \\
\hline ref|NC_009882.1_:c1025600-1025133 & Ribonuclease H & GTGCGCCGCTTTTACTACTT & CCCCGTTTGATATTTTACGC \\
\hline ref|NC_009882.1_:79249-81117 & Enzima GidA com modificação tRNA uridina 5-carboximetilaminometil & GAAATCGATGCACTTGATGG & TCTAGGTCCCCAAACTGCTG \\
\hline ref|NC_009882.1_c1203242-1201938 & Citrato sintase tipo II & ATGGGTTTTGGTCATCGTGT & GTTGTCTAGCTGCCCGAGTT \\
\hline ref|NC_009882.1_:c431296-429542 & Proteína AprD (alkaline protease secretion ATP-binding) & CACTTGGTGAAGCTACCGAAT & ATTCTTCATCATTCCCATTGC \\
\hline ref|NC_009882.1_:577205-579712 & Leucil-tRNA sintetase & TGGCAGTACATTTGGCAAGA & CATGGATTTTACCGGAAGGGA \\
\hline ref|NC_009882.1_:500770-502338 & Lisil-tRNA sintetase & CCTGAAATGGTGGCACAGTA & GAGCGAAGCTTTGCATTCAT \\
\hline ref|NC_009882.1_:616905-619217 & Protease La ATP-dependente & AAAGCTCCAAATTGCCAGA & ATCCAAAAGTGCCATCTCG \\
\hline ref|NC_009882.1_:402739-403515 & Proteína cysQ & TCGATCCTATTGATGGGACA & ATATCAAGCCGATGGTTGG \\
\hline ref|NC_009882.1_:82427-83287 & Proteína J do estágio 0 da esporulação & AATTTGCCGCAGTCTATTCAA & TCGGCTATTACTTCTGCATGTTC \\
\hline ref|NC_009882.1_:1082-1399 & Tiorredoxina & TGCGGACCGTGTAAAATGT & GAAGGAGTGTTAGGATTTTCATCA \\
\hline ref|NC_009882.1_:676576-677049 & Fator IF-3 da iniciação da tradução & ATGCACGGCGTCGTAAATA & TACAGACAGGGGGTACAGCA \\
\hline ref|NC_009882.1_:115915-116844 & Fator de enlongação Ts & CGGTGCAGGTATGATGGAT & TGCAGCAGCAGCTAAACC \\
\hline ref|NC_009882.1_:1236834-1237097 & Proteína J induzida por danos no DNA & AGCAGCTTTAGTGCTTGCTG & GTGGTTCAAACGGCAATG \\
\hline ref|NC_009882.1_:c1234383-1234144 & Antitoxina do sistema StbD toxina-antitoxina & GCCAGCTGAATTATATGAGCA & AACCGCTATTGCCTTTTTCTT \\
\hline ref|NC_009882.1_:c881085-879286 & Proteína ntrY de regulação de nitrogênio & GACGAGAATCCGGGAAAATA & TATTAGCTCAGGCGGGAATC \\
\hline ref|NC_009882.1_:991314-992378 & Proteína de resistência a biciclomicina & GGGATATCATCGGTTGCAG & AGGGCAATAGTGCCGTTTA \\
\hline ref|NC_009882.1_:487702-488622 & Recombinase XerD tirosina sítio específica & CGCGTTTAATCCGGTTCTTA & TTGAGAGCAATGTTCAAGTAACG \\
\hline ref|NC_009882.1_:c277476-277213 & DNA girase subunidade $\mathrm{A}$ & GCTGGTTTTACCAAACCACTT & GCTATTATGCCGAACTTTGGT \\
\hline ref|NC_009882.1_:c1249026-1247194 & Proteína de reparo e emparelhamento de DNA & CCTTACTGCGTCAAATGGAAA & CGTCCAAATAAGCGTTCGAT \\
\hline ref|NC_009882.1_:608404-609831 & Succinato semialdeído desidrogenase & CGGCGGTAAAACTGTTGATA & AGCAACTACCGGACCGAATA \\
\hline
\end{tabular}


APÊNDICE B - Continuação.

\begin{tabular}{|c|c|c|c|}
\hline CDS & Gene alvo & Oligonucleotídeo senso & Oligonucleotídeo antissenso \\
\hline ref|NC_009882.1_:c406932-406498 & Ribose-5-fosfato isomerase B & TTGATACTCGGAGCAAAAACC & TAGGCGGGTGCTATGTCTG \\
\hline ref|NC_009882.1_:C271743-269956 & Chaperona HscA & TCTCAATACTCCGGCACTTTTTT & TGCAATTTCAGGGACTCTCA \\
\hline ref|NC_009882.1_:c272234-271734 & Co-chaperona HscB & ATGCCTTAAAGCGTGCTGA & GCTTAATTCTAGCGGCGAAA \\
\hline ref|NC_009882.1_:232567-232908 & Proteína contendo domínios repetidos de anquirina 1 & ATGATGCTAGCCGCAGAAAG & AGGGAAGTCATTCCGGTTTT \\
\hline ref|NC_009882.1_:513850-514026 & Proteína contendo domínios repetidos de anquirina 2 & CCCAGAAAACAAAAGTACCATACA & СTCTAAAGCAGTATCACCATTCTCA \\
\hline ref|NC_009882.1_:514056-514307 & Proteína contendo domínios repetidos de anquirina 3 & GGCAGAGCGGTTAATAAAACA & TTTTAAGCGCTGTAATCTGTCAA \\
\hline ref|NC_009882.1_:c815948-815700 & Proteína contendo domínios repetidos de anquirina 4 & ATACCTTTGCATGCGGTTG & TGCGTTGATATCAGCACCAT \\
\hline ref|NC_009882.1_:c11968-11702 & Proteína contendo domínios repetidos de anquirina 5 & TATTAAGCTGCTGCCACCTG & ATTCCCTTACCTCGGCAAAT \\
\hline ref|NC_009882.1_:c12474-12022 & Proteína contendo domínios repetidos de anquirina 6 & ATCAATCCGATGAGGATGGT & AGCCTCGTCAGACATCTTGG \\
\hline ref|NC_009882.1_:c214853-212547 & Proteína de superfície externa 1 (omp1) & TAGTCGGTACCGGGAAACTG & CGCCAAGTGATAACTCACGA \\
\hline ref|NC_009882.1_:c720461-719856 & Subunidade proteolítica da protease Clp ATP-dependente & CGAGAAGGGGATGCGTTAT & AGGGTTTCTTGAGCATGGATT \\
\hline ref|NC_009882.1_:158821-159621 & Peptidase sinal 1 & AGAGTGGGGGTCTTTTGCTT & CTTTCATAGACCCGGTTGGA \\
\hline ref|NC_009882.1_:C473994-471502 & Proteína de membrana de ligação & TAGATGCTTCACCTGCCACA & TAGGCGGTAAATCCGCAATA \\
\hline ref|NC_009882.1_:418652-418861 & Proteína hipotética A1G_02360 & CCGCTTTCTGGGTTGTCA & AGATGGTTTGTCGGTTCGTC \\
\hline ref|NC_009882.1_:c591845-591552 & Proteína hipotética A1G_03375 & ACTTAAATTTGTATGGGTGCTAAAA & TGCCCAATGATAAAACTGGA \\
\hline ref|NC_009882.1_:c1009998-1009702 & Proteína hipotética A1G_06045 & ACATCTCTTTCTACCGCTAAAATC & ACGCACGTCATCGAGGAAT \\
\hline ref|NC_009882.1_:c31143-30847 & Proteína hipotética A1G_00180 & TCAGGTACAATGGTAGGTGTCG & GCCGGCAATCATTCCTATTA \\
\hline ref|NC_009882.1_:1051294-1051470 & Proteína hipotética A1G_06350 & GCAAGGTGCAGGTCAAGAT & AGTTAGCTGAGCTGTGAGGACA \\
\hline ref|NC_009882.1_:C421714-421487 & Proteína hipotética A1G_02385 & CAAAAATCCGGTAAAGCTCCT & TATAGTTGTGCCGTCATCCATA \\
\hline ref|NC_009882.1_:c1127890-1127534 & Proteína hipotética A1G_06745 & GGGTTCTTGGGTGGATTGT & ACCGATGGCAACACGAAG \\
\hline ref|NC_009882.1_:524000-524968 & Proteína hipotética A1G_03000 & GCTTGGTGAATCGACCTTATT & GATAAAGGCGTATTTGCCTCA \\
\hline ref|NC_009882.1_:525229-525366 & Proteína hipotética A1G_03005 & TCCTAATGATGGGAAGTGTCA & AATTAGTGTCGGTAAAGCGGTAA \\
\hline ref|NC_009882.1_:c730245-729259 & Proteína hipotética A1G_04280 & GGTACAATAACAGGCGGGAAT & CGCGGGAATGACATAAAGA \\
\hline ref|NC_009882.1_:1250262-1250714 & Proteína hipotética A1G_07480 & TTGGAGAAGTAGGTGATTTTGG & TGGTAAACTCCGCTACCTTTTT \\
\hline ref|NC_009882.1_:1020437-1020736 & Proteína hipotética A1G_06100 & CACAAATGCGTCAGTCAGGT & GTAAAAAGCTTAGGCGCTTCG \\
\hline ref|NC_009882.1_:c871627-869777 & Proteína hipotética A1G_05165 & TTCTGATGAAGGTACAACTCCTGT & GGCTCCTGAATGACAAGAAAA \\
\hline ref|NC_009882.1_:c1061923-1061801 & Proteína hipotética A1G_06440 & TGCACGTAAAATGGGAAAGT & GACAGGGACGATGTCCTAAAA \\
\hline ref|NC_009882.1_:832062-832241 & Proteína hipotética A1G_04930 & GTTGGAAGCCAAGTAAGTGGT & CCTTTGATACTTCAAGCTTTGG \\
\hline ref|NC_009882.1_:312257-312475 & Proteína hipotética A1G_01755 & AGCGGGAATCCAACAATTA & GTCATTCCTGCGAAAGCA \\
\hline ref|NC_009882.1_:555321-555569 & Proteína hipotética A1G_03155 & CACTAGAAGTTCCGCCTCATT & ССТТСАТТАААТТСАССТТGТСС \\
\hline ref|NC_009882.1_:600281-600448 & Proteína hipotética A1G_03445 & TAGATTCGCTGGTCGTGGT & TGCTATTCTAGGCTCTTTTTCTGA \\
\hline ref|NC_009882.1_:c830629-830507 & Proteína hipotética A1G_04915 & AGGTGCCGAGCTTTATCTAACC & CACGGTTGCACCTAAAATTACA \\
\hline ref|NC_009882.1_:c621997-621737 & Proteína hipotética A1G_03570 & CCGCAGAAGCACAAAAATTA & TGCAAATAGCCCTGCTAATG \\
\hline
\end{tabular}




\section{APÊNDICE C - Proteínas hipotéticas de $R$. rickettsii moduladas pela mudança de temperatura em $10^{\circ} \mathrm{C}$.}

\begin{tabular}{|c|c|c|c|}
\hline \multirow[b]{2}{*}{ CDS } & \multirow[b]{2}{*}{ Anotação } & \multicolumn{2}{|c|}{ Fold-change } \\
\hline & & $\begin{array}{c}\text { Réplica } \\
\text { biológica } 1\end{array}$ & $\begin{array}{c}\text { Réplica } \\
\text { biológica } 2\end{array}$ \\
\hline ref|NC_009882.1_:289631-290197 & Proteína Hipotética A1G_01610 & 2,06 & 2,10 \\
\hline ref|NC_009882.1_:293809-293943 & Proteína Hipotética A1G_01635 & 1,75 & 1,54 \\
\hline ref||NC_009882.1_:c346202-345054 & Proteína Hipotética A1G_01945 & 2,26 & 2,12 \\
\hline ref|NC_009882.1_:c485893-485420 & Proteína Hipotética A1G_02765 & 2,29 & 1,69 \\
\hline ref||NC_009882.1_:524000-524968 & Proteína Hipotética A1G_03000 & 3,46 & 2,38 \\
\hline ref|NC_009882.1_:525229-525366 & Proteína Hipotética A1G_03005 & 4,29 & 2,72 \\
\hline ref|NC_009882.1_:526267-526467 & Proteína Hipotética A1G_03015 & 2,11 & 1,63 \\
\hline ref|NC_009882.1_:c535744-534896 & Proteína Hipotética A1G_03065 & 1,99 & 1,61 \\
\hline ref|NC_009882.1_:787589-787804 & Proteína Hipotética A1G_04655 & 1,84 & 1,94 \\
\hline ref|NC_009882.1_:807614-807820 & Proteína Hipotética A1G_04775 & 2,13 & 1,58 \\
\hline ref|NC_009882.1_:875046-875333 & Proteína Hipotética A1G_05190 & 1,81 & 2,18 \\
\hline ref|NC_009882.1_:c875454-875305 & Proteína Hipotética A1G_05195 & 2,99 & 2,57 \\
\hline ref|NC_009882.1_:c947519-946632 & Proteína Hipotética A1G_05640 & 2,23 & 1,85 \\
\hline ref|NC_009882.1_:c1026073-1025600 & Proteína Hipotética A1G_06150 & 1,76 & 1,85 \\
\hline ref|NC_009882.1_:c1193675-1193313 & Proteína Hipotética A1G_07135 & 1,99 & 1,67 \\
\hline ref|NC_009882.1_:1226140-1225526 & Proteína Hipotética A1G_07280 & 1,72 & 1,69 \\
\hline ref|NC_009882.1_:283121-283303 & Proteína Hipotética A1G_01585 & $-2,24$ & $-1,89$ \\
\hline ref|NC_009882.1_:c368094-367954 & Proteína Hipotética A1G_02080 & $-1,90$ & $-1,52$ \\
\hline ref|NC_009882.1_:443651-444028 & Proteína Hipotética A1G_02525 & $-1,83$ & $-1,63$ \\
\hline ref|NC_009882.1_:489832-490995 & Proteína Hipotética A1G_02795 & $-2,07$ & $-1,92$ \\
\hline ref|NC_009882.1_:520257-521780 & Proteína Hipotética A1G_02985 & $-2,50$ & $-1,99$ \\
\hline ref|NC_009882.1_:676096-676425 & Proteína Hipotética A1G_03925 & $-1,70$ & $-1,77$ \\
\hline ref|NC_009882.1_:691150-691590 & Proteína Hipotética A1G_04030 & $-2,31$ & $-1,84$ \\
\hline ref|NC_009882.1_:c748277-748155 & Proteína Hipotética A1G_04410 & $-1,95$ & $-1,85$ \\
\hline ref|NC_009882.1_:c759589-759365 & Proteína Hipotética A1G_04500 & $-2,22$ & $-1,70$ \\
\hline ref|NC_009882.1_:794728-796473 & Proteína Hipotética A1G_04720 & $-1,72$ & $-2,05$ \\
\hline ref|NC_009882.1_:c871627-869777 & Proteína Hipotética A1G_05165 & $-2,90$ & $-2,95$ \\
\hline ref|NC_009882.1_:1020437-1020736 & Proteína Hipotética A1G_06100 & $-2,96$ & $-1,56$ \\
\hline ref|NC_009882.1_:1115303-1116967 & Proteína Hipotética A1G_06690 & $-2,72$ & $-2,28$ \\
\hline ref|NC_009882.1_:1250262-1250714 & Proteína Hipotética A1G_07480 & $-3,02$ & $-2,21$ \\
\hline
\end{tabular}

Nota: A análise transcricional foi realizada por microarranjo de oligonucleotídeos. 


\section{APÊNDICE D - Proteínas hipotéticas de $R$. rickettsii induzidas pela alimentação sanguínea.}

\begin{tabular}{|c|c|c|c|}
\hline \multirow[b]{2}{*}{ CDS } & \multirow[b]{2}{*}{ Anotação } & \multicolumn{2}{|c|}{ Fold-change } \\
\hline & & $\begin{array}{c}\text { Réplica } \\
\text { biológica } 1\end{array}$ & $\begin{array}{c}\text { Réplica } \\
\text { biológica } 2\end{array}$ \\
\hline ref|NC_009882.1_:C32054-31221 & Proteína Hipotética A1G_00185 & 2,13 & 1,92 \\
\hline ref|NC_009882.1_:c43779-43210 & Proteína Hipotética A1G_00270 & 1,54 & 1,85 \\
\hline ref|NC_009882.1_:c58861-58682 & Proteína Hipotética A1G_00400 & 1,84 & 1,90 \\
\hline ref|NC_009882.1_:c96803-95487 & Proteína Hipotética A1G_00605 & 2,76 & 2,62 \\
\hline ref|NC_009882.1_:c103121-102387 & Proteína Hipotética A1G_00640 & 1,84 & 1,81 \\
\hline ref|NC_009882.1_:c122272-122108 & Proteína Hipotética A1G_00715 & 1,88 & 2,30 \\
\hline ref|NC_009882.1_:122409-123413 & Proteína Hipotética A1G_00720 & 1,53 & 2,07 \\
\hline ref|NC_009882.1_:c191555-190416 & Proteína Hipotética A1G_01045 & 1,83 & 2,15 \\
\hline ref|NC_009882.1_:c221811-221575 & Proteína Hipotética A1G_01195 & 1,91 & 2,38 \\
\hline ref|NC_009882.1_:c245095-244994 & Proteína Hipotética A1G_01325 & 1,99 & 1,99 \\
\hline ref|NC_009882.1_:255227-255586 & Proteína Hipotética A1G_01380 & 2,69 & 2,73 \\
\hline ref|NC_009882.1_:c268466-267525 & Proteína Hipotética A1G_01485 & 1,56 & 1,66 \\
\hline ref|NC_009882.1_:c269541-268471 & Proteína Hipotética A1G_01490 & 2,16 & 2,12 \\
\hline ref|NC_009882.1_:283121-283303 & Proteína Hipotética A1G_01585 & 1,83 & 1,91 \\
\hline ref|NC_009882.1_:312257-312475 & Proteína Hipotética A1G_01755 & 2,92 & 2,02 \\
\hline ref|NC_009882.1_:390739-390918 & Proteína Hipotética A1G 02215 & 2,05 & 2,15 \\
\hline ref|NC_009882.1_:c421714-421487 & Proteína Hipotética A1G_02385 & 3,76 & 3,45 \\
\hline ref|NC_009882.1_:436964-437104 & Proteína Hipotética A1G_02475 & 1,50 & 1,72 \\
\hline ref|NC_009882.1_:c551038-550655 & Proteína Hipotética A1G_03135 & 1,68 & 1,72 \\
\hline ref|NC_009882.1_:609991-610131 & Proteína Hipotética A1G_03495 & 1,91 & 2,71 \\
\hline ref|NC_009882.1_:634212-634331 & Proteína Hipotética A1G_03675 & 1,82 & 2,18 \\
\hline ref|NC_009882.1_:c741051-740596 & Proteína Hipotética A1G_04350 & 1,59 & 1,61 \\
\hline ref|NC_009882.1_:782754-783182 & Proteína Hipotética A1G_04620 & 2,12 & 1,70 \\
\hline ref|NC_009882.1_:c789805-789605 & Proteína Hipotética A1G_04675 & 2,09 & 1,59 \\
\hline ref|NC_009882.1_:c790607-790365 & Proteína Hipotética A1G_04690 & 1,88 & 2,01 \\
\hline ref|NC_009882.1_:c791063-790797 & Proteína Hipotética A1G_04700 & 2,15 & 2,31 \\
\hline ref|NC_009882.1_:838905-839507 & Proteína Hipotética A1G_04970 & 1,84 & 1,73 \\
\hline ref|NC_009882.1_:c889260-889108 & Proteína Hipotética A1G_05260 & 3,23 & 2,25 \\
\hline ref|NC_009882.1_:c913327-913094 & Proteína Hipotética A1G_05400 & 1,90 & 2,36 \\
\hline ref|NC_009882.1_:951876-952079 & Proteína Hipotética A1G_05665 & 1,92 & 1,96 \\
\hline ref|NC_009882.1_:994684-996585 & Proteína Hipotética A1G_05975 & 1,61 & 1,95 \\
\hline ref|NC_009882.1_:1051294-1051470 & Proteína Hipotética A1G_06350 & 4,12 & 3,01 \\
\hline ref|NC_009882.1_c1062928-1062575 & Proteína Hipotética A1G_06455 & 2,06 & 1,61 \\
\hline ref|NC_009882.1_:c1071820-1071686 & Proteína Hipotética A1G_06480 & 1,88 & 2,08 \\
\hline ref|NC_009882.1_c1072517-1072290 & Proteína Hipotética A1G_06485 & 1,55 & 1,85 \\
\hline ref|NC_009882.1_:1079986-1080216 & Proteína Hipotética A1G_06525 & 2,14 & 2,08 \\
\hline ref|NC_009882.1_:1100886-1103396 & Proteína Hipotética A1G_06650 & 1,75 & 2,04 \\
\hline ref|NC_009882.1_:c1127890-1127534 & Proteína Hipotética A1G_06745 & 2,94 & 2,69 \\
\hline ref|NC_009882.1_:c1233873-1233787 & Proteína Hipotética A1G_07345 & 1,96 & 2,10 \\
\hline ref|NC_009882.1_:1250262-1250714 & Proteína Hipotética A1G_07480 & 2,41 & 2,62 \\
\hline
\end{tabular}

Nota: A análise transcricional foi realizada por microarranjo de oligonucleotídeos. 


\section{APÊNDICE E - Proteínas hipotéticas de $R$. rickettsii reprimidas pela alimentação sanguínea.}

\begin{tabular}{|c|c|c|c|}
\hline \multirow[b]{2}{*}{ CDS } & \multirow[b]{2}{*}{ Anotação } & \multicolumn{2}{|c|}{ Fold-change } \\
\hline & & $\begin{array}{c}\text { Réplica } \\
\text { biológica } 1\end{array}$ & $\begin{array}{c}\text { Réplica } \\
\text { biológica } 2\end{array}$ \\
\hline ref|NC 009882.1: :6316-6077 & Proteína Hipotética A1G 00030 & $-2,39$ & $-2,17$ \\
\hline ref|NC 009882.1:13826-14749 & Proteína Hipotética A1G 00085 & $-1,98$ & $-1,68$ \\
\hline ref|NC_009882.1_:32218-32739 & Proteína Hipotética A1G_00190 & $-2,88$ & $-2,59$ \\
\hline ref|NC_009882.1_:87774-87914 & Proteína Hipotética A1G_00570 & $-1,64$ & $-1,90$ \\
\hline ref|NC_009882.1_c100796-100236 & Proteína Hipotética A1G_00630 & $-2,16$ & $-1,79$ \\
\hline ref|NC_009882.1_:117318-117707 & Proteína Hipotética A1G_00690 & $-1,85$ & $-2,37$ \\
\hline ref|NC_009882.1_:137058-140018 & Proteína Hipotética A1G_00820 & $-1,88$ & $-1,78$ \\
\hline ref|NC_009882.1_:140005-141990 & Proteína Hipotética A1G_00825 & $-1,77$ & $-1,59$ \\
\hline ref|NC_009882.1_c199098-196984 & Proteína Hipotética A1G_01070 & $-1,65$ & $-1,69$ \\
\hline ref|NC_009882.1_:210439-210642 & Proteína Hipotética A1G_01135 & $-1,96$ & $-1,89$ \\
\hline ref|NC $009882.1: 263542-263811$ & Proteína Hipotética A1G 01450 & $-5,74$ & $-5,90$ \\
\hline ref|NC_009882.1:c264827-264525 & Proteína Hipotética A1G 01455 & $-4,24$ & $-3,88$ \\
\hline ref||NC_009882.1_:285406-285849 & Proteína Hipotética A1G_01605 & $-2,76$ & $-2,19$ \\
\hline ref|NC_009882.1_:289631-290197 & Proteína Hipotética A1G_01610 & $-1,89$ & $-1,69$ \\
\hline ref|NC_009882.1_:333307-333474 & Proteína Hipotética A1G_01880 & $-2,49$ & $-2,64$ \\
\hline ref|NC_009882.1_:c333827-333624 & Proteína Hipotética A1G_01885 & $-1,89$ & $-2,03$ \\
\hline ref|NC_009882.1_:c346202-345054 & Proteína Hipotética A1G_01945 & $-1,87$ & $-1,52$ \\
\hline ref||NC_009882.1_:384409-384507 & Proteína Hipotética A1G_02175 & $-2,47$ & $-2,76$ \\
\hline ref|NC_009882.1_:c413519-412539 & Proteína Hipotética A1G_02330 & $-2,91$ & $-2,84$ \\
\hline ref|NC_009882.1_:c439531-439259 & Proteína Hipotética A1G_02495 & $-2,35$ & $-1,81$ \\
\hline ref|NC_009882.1_:c462530-461532 & Proteína Hipotética A1G_02620 & $-1,75$ & $-1,67$ \\
\hline ref|NC_009882.1_:495812-496729 & Proteína Hipotética A1G_02820 & $-1,66$ & $-1,94$ \\
\hline ref||NC_009882.1_:c498787-498383 & Proteína Hipotética A1G_02835 & $-3,73$ & $-3,82$ \\
\hline ref|NC_009882.1_:c499229-498807 & Proteína Hipotética A1G_02840 & $-3,30$ & $-2,77$ \\
\hline ref|NC_009882.1_:524000-524968 & Proteína Hipotética A1G_03000 & $-8,32$ & $-6,07$ \\
\hline ref|NC_009882.1:525229-525366 & Proteína Hipotética A1G 03005 & $-8,16$ & $-5,32$ \\
\hline ref|NC_009882.1:526267-526467 & Proteína Hipotética A1G 03015 & $-3,53$ & $-2,48$ \\
\hline ref|NC 009882.1: c533894-533406 & Proteína Hipotética A1G 03050 & $-3,04$ & $-2,31$ \\
\hline ref|NC_009882.1_:c535744-534896 & Proteína Hipotética A1G_03065 & $-2,81$ & $-2,05$ \\
\hline ref|NC_009882.1_:c536134-535754 & Proteína Hipotética A1G_03070 & $-2,20$ & $-1,73$ \\
\hline ref|NC_009882.1_:c537320-536325 & Proteína Hipotética A1G_03075 & $-3,65$ & $-2,43$ \\
\hline ref|NC_009882.1_:561253-561429 & Proteína Hipotética A1G_03195 & $-1,54$ & $-1,72$ \\
\hline ref|NC_009882.1_:726966-727136 & Proteína Hipotética A1G_04250 & $-2,08$ & $-2,15$ \\
\hline ref|NC_009882.1_:c727231-727037 & Proteína Hipotética A1G_04255 & $-3,02$ & $-2,67$ \\
\hline ref|NC_009882.1_:c727442-727242 & Proteína Hipotética A1G_04260 & $-4,51$ & $-3,61$ \\
\hline ref|NC_009882.1_:c727681-727544 & Proteína Hipotética A1G_04265 & $-7,60$ & $-8,08$ \\
\hline ref|NC_009882.1_:c727818-727639 & Proteína Hipotética A1G_04270 & $-6,03$ & $-7,16$ \\
\hline ref|NC_009882.1_:c730245-729259 & Proteína Hipotética A1G_04280 & $-7,85$ & $-6,86$ \\
\hline ref|NC_009882.1_c733692-733087 & Proteína Hipotética A1G_04305 & $-4,91$ & $-3,82$ \\
\hline ref|NC_009882.1_:767346-770225 & Proteína Hipotética A1G_04555 & $-1,66$ & $-1,72$ \\
\hline
\end{tabular}

Nota: A análise transcricional foi realizada por microarranjo de oligonucleotídeos. 


\section{APÊNDICE E - Continuação.}

\begin{tabular}{|c|c|c|c|}
\hline \multirow[b]{2}{*}{ CDS } & \multirow[b]{2}{*}{ Anotação } & \multicolumn{2}{|c|}{ Fold-change } \\
\hline & & $\begin{array}{l}\text { Réplica } \\
\text { biológica } 1\end{array}$ & $\begin{array}{c}\text { Réplica } \\
\text { biológica } 2\end{array}$ \\
\hline ref|NC_009882.1_:774111-774803 & Proteína Hipotética A1G_04585 & $-3,52$ & $-3,13$ \\
\hline ref|NC_009882.1_:c814522-814355 & Proteína Hipotética A1G_04840 & $-2,08$ & $-1,74$ \\
\hline ref|NC_009882.1_:c846798-845314 & Proteína Hipotética A1G_05015 & $-2,05$ & $-1,98$ \\
\hline ref|NC_009882.1_:c868072-867395 & Proteína Hipotética A1G_05140 & $-2,16$ & $-2,39$ \\
\hline ref|NC_009882.1_:875046-875333 & Proteína Hipotética A1G_05190 & $-6,27$ & $-4,46$ \\
\hline ref|NC_009882.1_:c875454-875305 & Proteína Hipotética A1G_05195 & $-7,99$ & $-4,45$ \\
\hline ref|NC_009882.1_c947519-946632 & Proteína Hipotética A1G_05640 & $-2,38$ & $-1,81$ \\
\hline ref|NC_009882.1_:983971-984123 & Proteína Hipotética A1G_05920 & $-2,36$ & $-2,02$ \\
\hline ref|NC_009882.1_c987677-987333 & Proteína Hipotética A1G_05940 & $-2,81$ & $-2,59$ \\
\hline ref|NC_009882.1_:992452-993807 & Proteína Hipotética A1G_05965 & $-2,76$ & $-2,23$ \\
\hline ref|NC_009882.1_:c1015646-1014858 & Proteína Hipotética A1G_06080 & $-4,90$ & $-4,13$ \\
\hline ref|NC_009882.1_:c1026073-1025600 & Proteína Hipotética A1G_06150 & $-1,98$ & $-1,79$ \\
\hline ref|NC_009882.1_:1043231-1043452 & Proteína Hipotética A1G_06275 & $-1,66$ & $-1,67$ \\
\hline ref|NC_009882.1_:c1050287-1049916 & Proteína Hipotética A1G_06330 & $-2,86$ & $-2,52$ \\
\hline ref|NC_009882.1_c1050466-1050275 & Proteína Hipotética A1G_06335 & $-4,30$ & $-3,32$ \\
\hline ref|NC_009882.1_:c1052108-1051542 & Proteína Hipotética A1G_06355 & $-2,72$ & $-2,05$ \\
\hline ref|NC_009882.1_:1117305-1117733 & Proteína Hipotética A1G_06700 & $-2,95$ & $-2,28$ \\
\hline ref|NC_009882.1_:c1164928-1163354 & Proteína Hipotética A1G_06985 & $-2,01$ & $-1,66$ \\
\hline ref|NC_009882.1_:c1175920-1175135 & Proteína Hipotética A1G_07015 & $-1,71$ & $-1,88$ \\
\hline ref|NC_009882.1_:c1193675-1193313 & Proteína Hipotética A1G_07135 & $-4,88$ & $-3,92$ \\
\hline ref|NC_009882.1_:1237534-1238550 & Proteína Hipotética A1G_07385 & $-2,28$ & $-1,94$ \\
\hline ref|NC_009882.1_:c1241293-1241123 & Proteína Hipotética A1G_07410 & $-1,93$ & $-2,03$ \\
\hline ref|NC_009882.1_:c1241821-1241363 & Proteína Hipotética A1G_07415 & $-2,43$ & $-2,29$ \\
\hline
\end{tabular}




\section{APÊNDICE F - Artigo de Periódico}

Galletti, MFBM; Fujita, A; Nishiyama-Jr, MY; Malossi, CD; Pinter, A; Soares, JF; Daffre, S; Labruna, MB; Fogaca, AC. (2013) Natural blood feeding and temperature shift modulate the global transcriptional profile of Rickettsia rickettsii infecting its tick vector. PlosOne (submetido).

\section{PLOS ONE}

\section{Natural Blood Feeding and Temperature Shift Modulate the Global Transcriptional Profile of Rickettsia rickettsii Infecting Its Tick Vector --Manuscript Draft--}

\begin{tabular}{|c|c|}
\hline Manuscript Number: & PONE-D-13-10640F2 \\
\hline Article T/pe: & Resesrch Avticle \\
\hline Full Title: & $\begin{array}{l}\text { Natural Blood Feeding and Temperature Shift Modulste the Global Tranecriptional } \\
\text { Profile of Ricketsia ricketteil Infecting lts Tidk Vector }\end{array}$ \\
\hline Short Tite: & In vivo tranecriptional profile of R. ricketteii \\
\hline Corresponding Author: & $\begin{array}{l}\text { Andrea Cristina Fogaca, Ph.D. } \\
\text { Universidf of SB̈o Paulo } \\
\text { SS̈o Paulo, SB̈o Paulo BRAZIL }\end{array}$ \\
\hline Kefwords: & $\begin{array}{l}\text { Ricketteis; Tick, Rock Mountain Spotted Fever, Bacterium, arthropod; } \\
\text { transcriptome; gene expreseion; microarraf; microfluidic RT-qPCR; temperature } \\
\text { shift, blood feeding; T4SS; anticoidant; vector-pathogen interaction; stress response }\end{array}$ \\
\hline Abstract: & 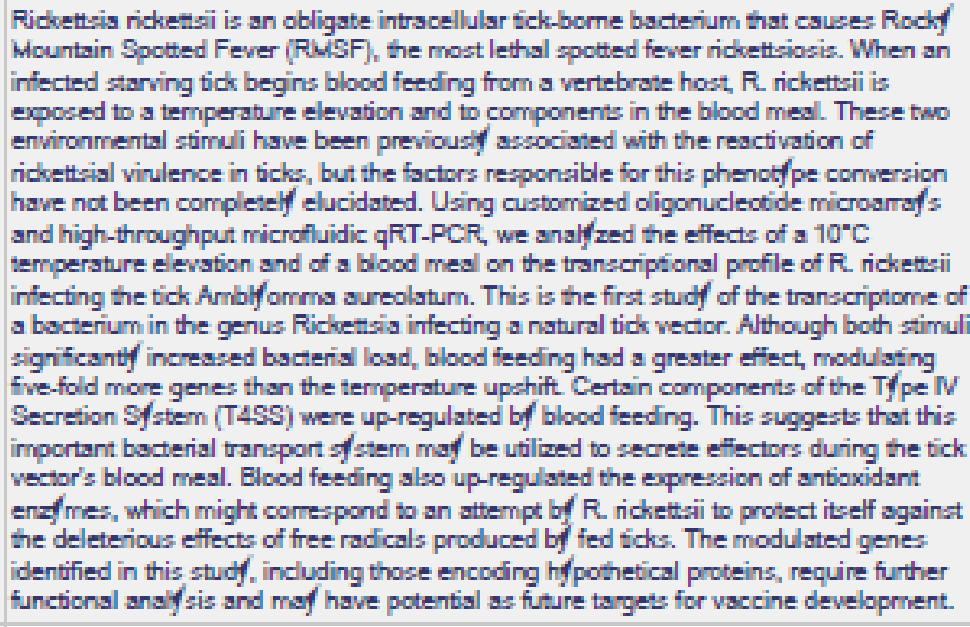 \\
\hline \multirow[t]{9}{*}{ Onder of Authors: } & Maria Fernanda B. M. Galeti \\
\hline & André Fujita \\
\hline & Milton Y. Nishifams-Jr \\
\hline & Camila D. Maloesi \\
\hline & Adriano Pinter \\
\hline & Joäo F. Soare: \\
\hline & Sirlei Duffre \\
\hline & Marcelo B. Labruna \\
\hline & Andrea Cristina Fogaca, Ph.D. \\
\hline
\end{tabular}




\title{
Natural Blood Feeding and Temperature Shift Modulate the Global Transcriptional Profile of Rickettsia rickettsii Infecting Its Tick Vector
}

\author{
Maria Fernanda B. M. Galletti ${ }^{1}$, André Fujita ${ }^{2}$, Milton Y. Nishiyama-Jr ${ }^{3}$, Camila \\ D. Malossi ${ }^{1}$, Adriano Pinter ${ }^{4}$, João F. Soares ${ }^{5}$, Sirlei Daffre ${ }^{1}$, Marcelo B. \\ Labruna $^{5}$, Andréa C. Fogaça ${ }^{1^{\star}}$
}

${ }^{1}$ Departamento de Parasitologia, Instituto de Ciências Biomédicas, Universidade de São Paulo, São Paulo, Brazil, ${ }^{2}$ Departamento de Ciências da Computação, Instituto de Matemática e Estatística, Universidade de São Paulo, São Paulo, Brazil, ${ }^{3}$ Departamento de Bioquímica, Instituto de Química, Universidade de São Paulo, São Paulo, Brazil, ${ }^{4}$ Superintendência de Controle de Endemias (SUCEN), São Paulo, Brazil, ${ }^{5}$ Departamento de Medicina Veterinária Preventiva e Saúde Animal, Faculdade de Medicina Veterinária e Zootecnia, Universidade de São Paulo, São Paulo, Brazil.

\section{Abstract}

Rickettsia rickettsii is an obligate intracellular tick-borne bacterium that causes Rocky Mountain Spotted Fever (RMSF), the most lethal spotted fever rickettsiosis. When an infected starving tick begins blood feeding from a vertebrate host, $R$. rickettsii is exposed to a temperature elevation and to components in the blood meal. These two environmental stimuli have been previously associated with the reactivation of rickettsial virulence in ticks, but the factors responsible for this phenotype conversion have not been completely elucidated. Using customized oligonucleotide microarrays and high-throughput microfluidic qRT-PCR, we analyzed the effects of a $10^{\circ} \mathrm{C}$ temperature elevation and of a blood meal on the transcriptional profile of $R$. rickettsii infecting the tick Amblyomma aureolatum. This is the first study of the transcriptome of a bacterium in the genus Rickettsia infecting a natural tick vector. Although both stimuli significantly increased bacterial load, blood feeding had a greater effect, modulating five-fold more genes than the temperature upshift. Certain components of the Type IV Secretion System (T4SS) were up-regulated by blood feeding. This suggests that this important bacterial transport system may be utilized to secrete effectors during the tick vector's blood meal. Blood feeding also up-regulated the expression of antioxidant enzymes, which might correspond to an attempt by $R$. rickettsii to protect itself against the deleterious effects of free radicals produced by fed ticks. The modulated genes identified in this study, including those encoding hypothetical proteins, require further functional analysis and may have potential as future targets for vaccine development. 


\section{Introduction}

The obligate Gram-negative intracellular bacterium Rickettsia rickettsii (Order: Rickettsiales, Family: Rickettsiacea) is the etiological agent of Rocky Mountain spotted fever (RMSF), the most lethal spotted fever rickettsiosis. RMSF has been reported in different countries on the American continent (for review, see [1,2]). In Brazil, where the disease is known as Brazilian spotted fever (BSF), a high fatality rate (around $40 \%$ ) has been recorded [2]. The endemic areas of BSF coincide with the presence of Amblyomma cajennense ticks, the major vector for $R$. rickettsii, and of Amblyomma aureolatum ticks, an important vector in the metropolitan area of the city of São Paulo [2]. Importantly, in this area, domestic dogs are the primary hosts that sustain natural populations of adult $A$. aureolatum ticks [2].

When an infected starving tick on the ground attaches to the warm skin of a vertebrate host and begins blood feeding, $R$. rickettsii is exposed to a temperature elevation as well as to the components of the blood meal, which is a rich source of nutrients. These factors have been previously associated with the reactivation of rickettsial virulence in ticks [3,4,5,6]. However, the mechanisms responsible for this phenotype conversion have not been completely elucidated. Bacteria significantly alter their transcriptome in response to environmental changes to adapt to different conditions. Therefore, studying the global transcriptional profile of pathogens under specific biological conditions can reveal the role of gene sets or pathways in adaptive processes (for review, see $[7,8]$ ).

The effects of temperature shifts and/or nutrient restriction on the gene expression profile of bacteria from the genus Rickettsia have been previously reported $[9,10,11,12]$. Nonetheless, all the previous studies were performed using bacteria infecting in vitro cultures of vertebrate and/or invertebrate cells. In the current study, we present the first transcriptional profile of $R$. rickettsii infecting a natural vector, the tick Amblyomma aureolatum. Using oligonucleotide microarrays and high-throughput microfluidic GPCR, the effects of two environmental stimuli were analyzed: a temperature shift and the acquisition of a blood meal by the tick. Although these two stimuli significantly promoted bacterial replication, blood feeding had a greater effect, also modulating five-fold more genes than the temperature shift. Blood feeding induced the expression of antioxidant enzymes, which might correspond to an attempt by $R$. rickettsii to protect itself against free radicals produced by fed ticks. Genes encoding Type IV Secretion System (T4SS) components were also up-regulated by blood feeding, suggesting that this system might play a role in secreting rickettsial effectors during the acquisition of a blood meal by a tick vector.

Interestingly,

RT-qPCR data 
showed that the effects of blood feeding combined to temperature upshift is similar to the effects of blood feeding alone, strengthening that the acquisition of the blood meal by the tick triggers major alterations on $R$. rickettsii gene expression. The products of the modulated genes identified in this work, including the hypothetical proteins, should be functionally characterized and may have potential as targets for vaccine development.

\section{Methods}

\section{Ethics Statement}

The protocol used in this work was approved by both Animal Experimentation Ethics Committees of the Faculty of Veterinary Medicine and Zootecnics (University of São Paulo, São Paulo, Brazil) and the Institute of Biomedical Sciences (University of São Paulo, São Paulo, Brazil). Guinea pigs and rabbits were purchased from commercial breeders that produce these animals for research use only. Guinea pigs were bought from Anilab (Paulínea, São Paulo, Brazil) and rabbits were bought from Criex (Mogi das Cruzes, São Paulo, Brazil). Domestic dogs were obtained from the Department of Preventive Veterinary Medicine and Animal Health of the University of São Paulo under the coordination of one of the co-authors (MBL) of the present study. These dogs are bred for research use only. Animals are euthanized through the intraperitoneal injection of a combination of ketamine and xylazine.

\section{Rickettsia rickettsii and Amblyomma aureolatum}

In this study, we used the virulent Taiaçu strain of $R$. rickettsii that was originally isolated from a naturally infected $A$. aureolatum tick by inoculating guinea pigs with the tick homogenate [13]. Since its isolation, this strain has been maintained via cryopreservation of infected organs from the guinea pigs.

We also used adult females from the fifth generation of an $A$. aureolatum laboratory colony, which started with engorged females $\left(F_{0}\right)$ collected from domestic dogs in Atibaia in the state of São Paulo. Ticks from this colony were first infected with the Taiaçu strain of $R$. rickettsii by feeding $F_{1}$ larvae on guinea pigs inoculated with the cryopreserved organs from the infected guinea pigs, as detailed in [14]. Therefore, ticks were exposed to a $R$. rickettsii strain that has never been cultured in vitro. During the previous four laboratory generations, $R$. rickettsii was maintained by transstadial perpetuation and transovarial transmission in $100 \%$ of the individuals in this colony [15]. In addition, $R$. rickettsii was shown to be highly virulent; all the guinea pigs and rabbits that served as hosts during the larval, nymph, or adult stages in the $F_{1}$ through $F_{4}$ generations developed severe clinical illness, with a $50 \%$ fatality rate among the guinea pigs [15]. Off-host developmental stages were held in an incubator at $25^{\circ} \mathrm{C}$ and $95 \%$ relative humidity $(\mathrm{RH})$. 


\section{Exposure to environmental stimuli}

R. rickettsii-infected unfed adult females $\left(F_{5}\right)$ were incubated at either $25^{\circ} \mathrm{C}$ (Group 1, G1) or $35^{\circ} \mathrm{C}$ (Group 2, G2) for 3 days or fed on domestic dogs (Canis familiaris) for 3 days (Group 3, G3). Canine infestations were performed as previously described [15] except the ticks were manually detached from the dogs on the third feeding day. Immediately after incubation or feeding, the ticks were washed in $70 \%$ ethanol and sterile phosphate-buffered saline (PBS) (10 $\mathrm{mM} \mathrm{NaH} \mathrm{PO}_{4}, 1.8 \mathrm{mM} \mathrm{KH}_{2} \mathrm{PO}_{4}, 140 \mathrm{mM} \mathrm{NaCl}$, and $\left.2.7 \mathrm{mM} \mathrm{KCl}, \mathrm{pH} 7.4\right)$ for 10 minutes each. To collect organs, the tick cuticle was carefully cut, and the integument was separated from the internal organs, which were transferred to $100 \mu \mathrm{L}$ RNAlater ${ }^{\circledR}$ Solution (Life Technologies, USA).

\section{DNA and RNA extraction}

Genomic DNA (gDNA) and total RNA from the organs of each individual tick were obtained simultaneously using the InviTrap ${ }^{\circledR}$ TwinSpin Cell Mini Kit (STRATEC, Germany) according to the manufacturer's instructions.

\section{Real-time quantitative PCR (qPCR) to quantify $R$. rickettsii}

The total number of rickettsiae per adult female tick was quantified by realtime qPCR using specific primers and a TaqMan ${ }^{\circledR}$ probe for the citrate synthase gene $(g / t A)$ as previously described [16] except for a few modifications, including deleting two bases in the sense primer [17]. Briefly, 8 pmol of each gltA-specific primer (sense and antisense), 0.2 pmol of probe and $100 \mathrm{ng}$ of gDNA were added to $10 \mu \mathrm{L}$ of Quantimix Easy Probes Kit (Biotools, Spain), and the reaction volume was brought to $20 \mu \mathrm{L}$ with ultrapure water. The reactions were performed on a Mastercycler ${ }^{\circledR}$ ep Realplex ${ }^{2}$ detection system (Eppendorf, Germany) using the following thermocycler program: 2 minutes at $95^{\circ} \mathrm{C}$ followed by 40 cycles of 15 seconds at $95^{\circ} \mathrm{C}, 15$ seconds at $55^{\circ} \mathrm{C}$, and 20 seconds at $68^{\circ} \mathrm{C}$. Three technical replicates were analyzed for each sample.

\section{Microarray design}

The complete genome sequence of the Sheila Smith strain of $R$. rickettsii (GenBank CP000848.1) [18] was submitted to the Agilent eArray web tool for gene expression probe design (https://earray.chem.agilent.com/earray/). Subsequently, a total of 13,04960 -mer probes representing $99.5 \%$ of the bacterial genome (at least six probes per coding sequence) were spotted on an $8 \times 15 \mathrm{k}$ chip.

RNA amplification and labeling

Each of the two biological replicates used in the microarray experiments contained total RNA from seven adult females harboring between $1.6 \times 10^{8}$ and $2.2 \times 10^{8}$ bacteria. After DNasel (Promega, USA) treatment, RNA was reverse transcribed and amplified using the MessageAmp ${ }^{\mathrm{TM}}$ II - Bacteria RNA 
Amplification Kit (Life Technologies, USA) according to the manufacturer's instructions. To obtain technical replicates (dye swap), the resulting amplified RNA (aRNA) was divided into two samples that were independently labeled with Cy3 or Cy5 using the Genomic DNA ULS ${ }^{\text {TM }}$ Labeling Kit (Agilent Technologies, USA). After labeling, G2 samples were mixed with either G1 (to evaluate the effects of a temperature shift) or G3 (to evaluate the effects of blood feeding) samples and hybridized to the microarrays according to the Gene Expression FFPE protocol (Agilent Technologies, USA). Total RNA obtained from noninfected ticks was also similarly processed and hybridized to the $R$. rickettsii microarray to check probe specificity. The coding sequences (CDS) represented by microarray oligonucleotides that cross-hybridized with noninfected $A$. aureolatum transcripts were removed from the data analysis.

\section{Microarray scanning and data analyses}

The chips were scanned on a High-Resolution C Scanner (Agilent Technologies, USA). Images were visually inspected in order to detect eventual air bubbles and dust. Both signal data extraction and spot quality control were carried out using Feature Extraction 10.5 (Agilent Technologies) with default parameters. Spots with low quality, identified by Feature Extraction 10.5, were set to "not available" (NA) and were removed from the dataset. Data were normalized using the loess algorithm as implemented previously [19]. Foldchanges were obtained by calculating the mean value of a gene (summation of normalized probe intensity divided by the number of probes for each gene) and subsequently by calculating the ratios of the normalized intensities of the G2/G1 and G3/G2 samples. Only genes where $65 \%$ of the probes exhibited the same transcriptional pattern and a fold-change $\geq 1.5$ in both biological replicates were considered to be modulated.

A detailed microarray description can be found in the NCBI Gene Expression Omnibus (GEO) database under Accession Number GPL16681. The complete dataset (Accession Number GSE44349) is publicly available according to MIAME guidelines [19].

\section{Conserved domain analysis}

The complete list of the modulated hypothetical proteins was screened for the presence of conserved domains using the NCBI Conserved Domain Database (CDD, http://www.ncbi.nlm.nih.gov/cdd).

\section{Microfluidic high-throughput RT-qPCR}

To validate the microarray data, specific primers for 85 selected genes (Table S1) were designed using Primer3 [20] and synthesized by Life Technologies (USA). Two hundred ng of the RNA extracted from total organs of one $A$. aureolatum were used as template for reverse transcription (RT) in complementary DNA (cDNA) using M-MLV Reverse Transcriptase (Life Technologies, USA) according to manufacturer's protocol. Twenty biological 
replicates (adult females harboring between $2.0 \times 10^{8}$ and $5.7 \times$ $10^{8}$ rickettisiae) from each biological group (G1, G2 and G3) were analyzed. cDNA was pre-amplified using a mixture containing the 85 primer pairs (200nM each) and the TaqMan ${ }^{\circledR}$ PreAmp Master Mix 2x (Life Technologies, USA). Amplification reactions were carried out on a Mastercycler ${ }^{\circledR}$ Gradient (Eppendorf, Germany) with a thermocycler program of $95^{\circ} \mathrm{C}$ for 10 minutes and 14 cycles of $95^{\circ} \mathrm{C}$ for 15 seconds and $60^{\circ} \mathrm{C}$ for 4 minutes each. Pre-amplified cDNA samples and primers were combined in wells of a 96x96 chip (Fluidigm, USA) using the integrated fluidic circuit (IFC) controller (Fluidigm, USA) following manufacturer's instructions. Reactions were performed on a BioMark ${ }^{\mathrm{TM}}$ reader (Fluidigm, USA) using a thermocycler program of $50^{\circ} \mathrm{C}$ for 2 minutes, $70^{\circ} \mathrm{C}$ for 30 minutes, $25^{\circ} \mathrm{C}$ for 10 minutes, $50^{\circ} \mathrm{C}$ for 120 minutes and $95^{\circ} \mathrm{C}$ for 10 minutes, followed by 35 cycles of $95^{\circ} \mathrm{C}$ for 15 seconds and $60^{\circ} \mathrm{C}$ for 60 seconds. In order to exclude non-specific primers, the same procedure was performed using pre-amplified cDNA samples of non-infected females. To determine the efficiency of each primer pair, standard curves were generated using five serial dilutions $(1: 1,1: 2,1: 4,1: 8,1: 16)$ of a unique cDNA sample composed by a pool of pre-amplified cDNAs from all biological samples. Only primers presenting efficiencies between $90-100 \%$ were considered.

The threshold cycle $(\mathrm{Ct})$ was determined using the BioMark ${ }^{\mathrm{TM}}$ qPCR analysis software (Fluidigm, USA). Threshold values were normalized according to the $\mathrm{Ct}$ of the reference gene (methionyl-tRNA synthetase), which is expressed at similar levels under all conditions tested, according to our microarray and RT-qPCR data. The $2^{-\Delta \Delta C t}$ equation [20] was used to calculate the relative expression of select genes in G2 versus G1 (to evaluate the effects of a temperature shift), G3 versus G2 (to evaluate the effects of exposure to blood feeding), and G3 versus G1 (to evaluate the combined effects of both stimuli). To identify the outliers, we considered the Tukey criterion [22]. The medians of fold-changes of samples from the same biological group were analyzed using the Wilcoxon test to statistically validate the differentially expressed genes. $P$-values were corrected for multiple comparisons by the False Discovery Rate (FDR) method [21]. Data was considered significantly different at $p<0.05$.

\section{Results}

\section{Global gene expression analysis}

To obtain Rickettsia rickettsii samples for the transcriptional studies, we performed a laboratory-controlled blood feeding infection of ticks with the virulent Taiaçu strain. Amblyomma aureolatum $\mathrm{F}_{1}$ larvae were fed on experimentally infected Cavia porcellus and reared through five consecutive generations in the laboratory. After the $F_{5}$ adults emerged, unfed females were 
incubated at either $25^{\circ} \mathrm{C}(\mathrm{G} 1)$ or $35^{\circ} \mathrm{C}(\mathrm{G} 2)$ for 3 days or were fed on dogs (G3) for 3 days. Real-time quantitative PCR demonstrated that $100 \%$ of the ticks in the three biological groups were infected with $R$. rickettsii. Moreover, the bacterial load in G3 $\left(7.2 \pm 4.0 \times 10^{8}\right)$ and in G2 $\left(3.4 \pm 2.2 \times 10^{8}\right)$ is higher than in G1 $\left(2.2 \pm 2.0 \times 10^{8}\right)$ ticks (Figure 1), suggesting that both temperature upshift and blood feeding stimulated rickettsial replication.

Total RNA from infected ticks was reverse transcribed, amplified, and labeled for hybridization to oligonucleotide microarrays representing $99.5 \%$ of the 1,345 CDS of the Sheila Smith strain of $R$. rickettsii. As a control, total RNA extracted from uninfected ticks was similarly processed and hybridized to $R$. rickettsii microarrays. CDS represented by probes that cross-hybridized with the control transcripts $(5.7 \%)$ were removed from the data analysis (data not shown). A similar percentage of cross-hybridization with host-cell transcripts was observed by [12].

Microarray screening showed that a $10^{\circ} \mathrm{C}$ temperature increase modulated the expression of 44 rickettsial genes with a fold-change $\geq 1.5$, of which 14 encoded proteins with annotated function (Table S2) and 30 encoded hypothetical proteins (Table S3). On the other hand, the acquisition of a blood meal by the tick vector affected the expression of 221 genes, which comprised 118 proteins with annotated function (Table S4) and 103 hypothetical proteins (Table S5). These results indicated that blood feeding substantially affected the $R$. rickettsii gene expression profile, leading to the differential expression of fivefold more genes than the temperature shift.

Among the 44 genes modulated by the temperature increase, 25 were induced and 19 were repressed. The COG (Clusters of Orthologous Groups) functional categories that comprised the majority of the up-regulated genes with annotated function were (i) posttranslational modification and protein turnover and (ii) inorganic ion transport and metabolism (Figure 2A). The down-regulated genes were equally distributed in the following categories: (i) nucleotide, (ii) carbohydrate, and (iii) lipid transport and metabolism; (iv) energy production and conversion; and (ii) replication, recombination, and repair (Figure 2A).

Of the 221 genes differentially expressed in fed compared with unfed ticks in G2, 80 were up-regulated and 141 were down-regulated. Most of the annotated down-regulated genes were involved in translation, ribosomal structure, and biogenesis, whereas the majority of the up-regulated genes were associated with the following categories: (i) energy production and conversion; (ii) replication, recombination, and repair; and (iii) intracellular trafficking, secretion, and vesicular transport (Figure 2B).

Certain up-regulated genes in the last category encode components of the Type IV Secretion System (T4SS; VirB8, VirB9, VirB10, VirB11, and VirD4) (Table S4). Differently, virB3, which encodes another T4SS component, was repressed. Remarkably, three genes encoding the cell surface antigen-like protein Sca8 and one encoding Sca10 were significantly down-regulated (foldchange $\geq 2.0$ ) by blood feeding, and the gene expression of enzymes related to 
protection against oxidative stress (ferredoxin, glutaredoxin 3 , and thioredoxin peroxidase 1) was induced (Table S4).

In silico domain analysis of the hypothetical proteins

As expected, numerous genes encoding hypothetical proteins in $R$. rickettsii were modulated by both temperature change and blood feeding (Tables S3 and S5, respectively). The nucleotide sequences of all the genes encoding hypothetical proteins were submitted for a bioinformatics search against the NCBI Conserved Domain Database (CDD). Of the 133 analyzed sequences, 89 contained domains related to other proteins in the CDD (Tables S3 and S5). Analyzing the hypothetical proteins modulated by temperature change revealed that they contained domains similar to SpoT (A1G_06100) and iron permease (A1G_03065) (Table S3). Interestingly, two hypothetical proteins similar to VirB6 (A1G_00820 and A1G_00825), one to VirB2 (A1G_01380), two to ankyrin repeat proteins (A1G_02840 and A1G_04305), and one to thioredoxin (A1G_00185) were among the hypothetical proteins modulated by blood feeding (Table S5).

\section{Microarray data validation}

In order to validate the microarray data, 35 modulated genes were analyzed by high-throughput microfluidic RT-qPCR (Table 1). In addition, the gene expression of 26 genes that were previously reported to play an important role in bacterial physiology, stress response, and/or virulence $[22,23,24,25,26,27,28,29,30,31,32,33]$ was also analyzed (Table 2). All the 61 primer pairs presented efficiencies between $90 \%$ and $100 \%$ and were used to calculate the relative expression in G2 versus $\mathrm{G} 1$ (to evaluate the effects of temperature upshift), G3 versus G2 (to evaluate the effects of exposure to blood feeding) and G3 versus G1 (to evaluate the combined effects of both stimuli). No amplification was detected when cDNA from non-infected females was used as template in reactions, attesting primer specificity. There was an overall concordance of $100 \%$ between the microarray and the RT-qPCR analyses (Table 1). Interestingly, a similar modulation profile was observed upon blood feeding alone or combined to the temperature upshift for 48 from the 61 analyzed genes (Tables 1 and 2). The other 13 genes presented different patterns or transcription levels were not statistically significant.

\section{Discussion}

Global transcriptional studies are a useful tool to investigate the response of rickettsiae to environmental stimuli using in vitro vertebrate and invertebrate host cell cultures $[9,10,11,12,34]$. In this study, we used customized oligonucleotide microarrays to evaluate the global transcriptional profile of the obligate intracellular bacterium Rickettsia rickettsii infecting its vector, the 
Amblyomma aureolatum tick. To the best of our knowledge, this is the first report on the gene expression of a highly virulent bacterium in the genera Rickettsia infecting a natural tick vector. The genome of the Sheila Smith strain of $R$. rickettsii (GenBank CP000848.1) was used as reference to design the oligonucleotide microarrays. A genomic comparison of this virulent strain with the avirulent lowa strain had shown 143 deletions and 492 single nucleotide polymorphisms (SNPs) between the two genomes [18]. Among the SNPs, 339 were found in predicted open reading frames (ORFs), but only 188 SNPs result in non-synonymous amino acid substitutions [18]. Moreover, only four genes were differentially expressed by hybridization of the RNA of the virulent strains Sheila Smith or $\mathrm{R}$ with microarrays containing both the Sheila Smith and lowa genomes, indicating that the genetic differences between the two strains do not alter gene expression [18].

Because of limited rickettsial RNA in infected ticks, we performed whole transcriptome linear amplification prior to RNA labeling and microarray hybridization. As demonstrated previously $[34,35,36]$, this procedure is critical for obtaining good transcriptional data. Using this methodology, we investigated the influence of two environmental stimuli, a $10^{\circ} \mathrm{C}$ temperature elevation and the acquisition of a blood-meal by the tick vector, on $R$. rickettsii global gene expression. In total, 265 genes were detected to be modulated by either the temperature upshift or blood feeding. Thirty five of the 265 modulated genes $(>13 \%)$ were selected for further high-throughput RT-qPCR analysis. A correlation of $100 \%$ between RT-qPCR and microarray data was obtained, which increased our confidence in the microarray data.

The temperature upshift and blood feeding, which have been previously associated with the reactivation of rickettsial virulence in ticks $[3,4,5,6]$, specifically altered the expression of distinct gene sets. Remarkably, blood feeding modulated five-fold more genes than the temperature shift. The substantial change in the $R$. rickettsii transcriptional profile elicited by the blood meal coincided with increased bacterial load in fed compared with starving ticks. Therefore, it is plausible to suppose that nutrients in the blood meal may stimulate bacterial proliferation in fed ticks. In fact, 16 of the 80 genes upregulated by the blood meal were related to (i) energy production and conversion or (ii) replication, recombination, and repair. Nonetheless, genes involved in translation, ribosomal structure, and biogenesis are mostly downregulated. Therefore, we can hypothesize that $R$. rickettsii may repress translation and ribosome structure/biogenesis genes when nutrients are abundant to avoid a disordered proliferation, what could lead to vector's death. The repression of the 30S ribosomal protein S2 (A1G_00680) was validated by RT-qPCR. We also observed that the encoding genes for two ATP/ADP carrier proteins (A1G_00515 and A1G_06265) and one glycerol-3-phosphate transporter (A1G_00520) are repressed in fed ticks, suggesting that a fewer number of membrane transporter molecules are necessary in a nutrient-rich environment. 
Blood acquisition also up-regulated genes associated with trafficking and secretion, including components of the Type IV Secretion System (T4SS). The T4SS is a protein complex that delivers macromolecules (effectors) from the bacterium to the host cell where they interact with host proteins, enabling bacterial replication and survival [37]. Its importance has been studied in members of the Order Rickettsiales, such as Anaplasma phagocytophilum and Ehrlichia chaffeensis (for review, see [23]), and in Coxiella burnetii [38]. Here, we demonstrated that blood feeding modulated the expression of $R$. rickettsii genes that encode T4SS components. The expression of virB3, virB9, virB10, virB11, and virD4 was statistically validated by microfluidic RT-qPCR. These data indicated that this bacterial transport system might play an important role in secreting rickettsial effectors during blood meal acquisition by the tick vector. However, whereas virB9, virB10, virB11, and virD4 were induced by this stimulus, virB3 was repressed. Because virB3 is located on a different region of the $R$. rickettsii chromosome (Figure 3), it is possible that this gene is controlled by a different regulatory mechanism. Interestingly, two hypothetical proteinencoding genes, A1G_00820 and A1G_00825, that are located downstream of virB3 (Figure 3) were also repressed by tick blood feeding, while the modulation of the ATPase VirB4 (A1G_00815) was not detected. These two hypothetical proteins contain VirB6 domains (Tables 2 and S5) and were also statistically validated by RT-qPCR. The presence of two copies of VirB6 in R. rickettsii agrees with a previous analysis of T4SS components in the genomes of several species of the genera Rickettsia [39]. Additionally, the hypothetical protein A1G_01380 was up-regulated by blood feeding and contains a VirB2 domain. This T4SS component has been previously described to be absent in Rickettsia spp. [39].

In contrast to what we observed, the gene expression of T4SS components was reported to be up-regulated during nutrient depletion in $R$. conorii, the causative agent of Mediterranean spotted fever [34]. Nevertheless, in addition to being a different species, the previously published study was performed in vitro using a culture of Vero cells as the host. The effects of nutrient deprivation were also investigated in $R$. rickettsii infecting Vero cells [12]. Under limiting iron conditions, five hypothetical protein-encoding genes were modulated with a fold-change $\geq 3.0$. One of the genes up-regulated by in vitro iron limitation encodes the hypothetical protein A1G_04305 [12]. We demonstrated that this protein encoding gene was repressed when $A$. aureolatum acquired a blood meal, which is a rich iron source. The domain analysis indicated that the hypothetical protein A1G_04305 contains ankyrin repeat domains (Table S5). Ankyrin repeat domains are protein motifs involved in protein-protein interactions that mediate diverse cellular processes [40]. Despite typically being found in eukaryotes, proteins containing ankyrin repeat domains (referred to as Anks) have also been described in bacteria, especially intracellular ones, where they act as T4SS effectors (for review, see [41,42]). Blood feeding downregulated another gene encoding a hypothetical protein (A1G_02840) with 
ankyrin repeat domain. It is possible that these two proteins act as T4SS effectors in mammals but not in ticks. The encoding genes of two additional ankyrin-repeat containing proteins (A1G_02960 and A1G_01255) were analyzed by RT-qPCR. Data showed that both genes are repressed by the blood meal, while A1G_01255 is induced by temperature upshift. Therefore, their role as T4SS effectors in host cells should be investigated.

The global transcriptional profile of the etiological agent of Lyme disease, Borrelia burgdorferi, has been reported to be modulated by the addition of blood to in vitro cultures [43]. The genes encoding the outer surface protein C (OspC) and a Lon protease, an enzyme possibly involved in remodeling the spirochete outer surface, were up-regulated. In $R$. rickettsii, the acquisition of a blood meal by the tick vector stastistically repressed three genes encoding the cell surface protein Sca8, one encoding Sca10, and one encoding Sca13. The Sca (surface cell antigen) group includes the two major Rickettsia surface proteins rOmpA (Sca0) and rOmpB (Sca5) (for review, see [44]). rOmpA and rOmpB were previously reported to be involved in the attachment and/or invasion of mammalian cells by rickettsiae $[26,29]$. In addition, it was demonstrated that the invasion of Vero cells by $R$. conorii involved the interaction of rOmpB with Ku70 , a $70 \mathrm{kDa}$ host protein [30,45]. Although the modulation of rOmpA and rOmpB was not detected by microarray experiments, RT-qPCR analysis showed that rOmpB is up-regulated upon blood feeding alone or combined to temperature upshift. Therefore, studies on the role of rOmpB in invasion of vector and host cells are warranted.

The heme component of the blood meal contributes to the formation of free radicals in blood feeding arthropods (for review, see [46]). Therefore, it is plausible to suppose that $R$. rickettsii may be under oxidative stress in fed ticks. The production of reactive oxygen and nitrogen species (ROS and RNS, respectively) is an ancient immune response to infection and therefore is widespread in the animal kingdom (for review, see [47]). Indeed, the hemocytes of the cattle tick Rhipicephalus microplus have been reported to produce ROS when stimulated by bacteria [48]. ROS can oxidize DNA, lipids, and proteins, interfering with their function [49]. Importantly, it has been suggested that bacterial DNA may be the primary target of ROS when free iron concentrations are high [50]. In the current study, we demonstrated that blood feeding statistically induced the expression of three antioxidant enzymes (thioredoxin peroxidase 1, glutaredoxin 3 , and ferredoxin) and one hypothetical protein with thioredoxin domain (A1G_00185). It is possible that the induction of these enzymes reflects an attempt by $R$. rickettsii to protect itself against the deleterious effects of free radicals in fed ticks. Interestingly, the glutaredoxin (Grx) and thioredoxin ( $\operatorname{Trx}$ ) systems are involved in returning the cellular proteome to normal after or during unfavorable conditions (for review, see [49]). 
The exposure of $R$. rickettsii to a $10^{\circ} \mathrm{C}$ temperature increase also altered the global transcriptional profile of unfed ticks. This temperature upshift naturally occurs when a starving tick on the ground climbs onto a vertebrate host and contacts its warm skin. This stimulus, compared with blood feeding, did not extensively alter gene transcription. This limited response may partly be explained by the absence of an ideal microenvironment for the bacteria within the starving tick, where energy and nutrients are scarce. A limited gene expression response to temperature shift in $R$. rickettsii infecting a tick cell line $\left(22^{\circ} \mathrm{C}\right.$ to $\left.37^{\circ} \mathrm{C}\right)$ or Vero cells $\left(25^{\circ} \mathrm{C}\right.$ to $\left.34^{\circ} \mathrm{C}\right)$ in vitro has been reported [12]. Major gene expression alterations were only detected with larger temperature shifts [12]. In contrast, a temperature downshift $\left(37^{\circ} \mathrm{C}\right.$ to $\left.25^{\circ} \mathrm{C}\right)$ was previously reported to modulate the expression of several genes in $R$. typhi in an in vitro cell culture model, down-regulating several chaperonins and heat shock proteins [11]. Under a similar temperature shift $\left(25^{\circ} \mathrm{C}\right.$ to $\left.35^{\circ} \mathrm{C}\right)$, we observed the induction of only one heat shock protein (GrpE) by microarray experiments. The analysis of additional chaperones and heat shock proteins by microfluidic RTqPCR showed that the encoding genes of the co-chaperone HscB and the chaperonin GroEL are also up-regulated by the temperature elevation, while the molecular chaperone DnaK and chaperone protein HscA are repressed. This indicates that a $10^{\circ} \mathrm{C}$ temperature elevation does not trigger a heat-shock response in $R$. rickettsii as observed in $R$. typhi. Interestingly, the cold shocklike protein A1G_05630 was up-regulated by a temperature upshift. Because A1G_05630 is the unique cold-shock protein in $R$. rickettsii genome, this role should be addressed.

In summary, we identified distinct effects of blood feeding and a temperature shift on the transcriptional profile of the obligate intracellular virulent pathogen $R$. rickettsii infecting its natural tick vector $A$. aureolatum. Both conditions modulated bacterial gene expression, although the analyses revealed that blood feeding caused more significant effects, for instance, increasing bacterial load. Interestingly, a similar transcriptional profile was observed upon blood feeding alone or combined to the temperature upshift. This result strengthens that the components of blood meal triggers major alterations in rickettsial gene expression modulation than the temperature upshift. These two environmental stimuli simulate the challenges that the bacterium is actually exposed to when infecting its natural tick vectors and have been previously associated with the reactivation of bacterial virulence. Therefore, this is an important approach for identifying key molecules involved in bacterial biological processes and vector interactions that may have potential as targets for vaccine development. The modulated genes identified in this study, including those encoding hypothetical proteins, should be functionally characterized. 
Acknowledgements: We would like to thank Dr. Regina Maki Sasahara, Dr. Gerhard Wunderlich, and Dr. Roberto Marcondes Cesar Jr. for suggestions. We also thank Dr. Milton Moraes and Tiana Rosa de Brito for microfluidic RT-qPCR technical assistance. In addition, we would like to thank Dr. Rafael D. Rosa for assisting on figures editing, and Larissa Almeida Martins, Hebert Sousa Soares, and Francisco Borges Costa for technical assistance in tick colony maintenance.

\section{References}

1. Dantas-Torres F (2007) Rocky Mountain spotted fever. Lancet Infect Dis 7: 724-732.

2. Labruna MB (2009) Ecology of rickettsia in South America. Ann N Y Acad Sci 1166: 156-166.

3. Spencer RR, Parker RR (1923) Rocky Mountain spotted fever: infectivity of fasting and recently fed ticks. Public Health Reports 38: 333-339.

4. Policastro PF, Munderloh UG, Fischer ER, Hackstadt T (1997) Rickettsia rickettsii growth and temperature-inducible protein expression in embryonic tick cell lines. J Med Microbiol 46: 839-845.

5. Gilford JH, Price WH (1955) VIRULENT-AVIRULENT CONVERSIONS OF Rickettsia Rickettsii IN VITRO. Proc Natl Acad Sci U S A 41: 870-873.

6. Hayes SF, Burgdorfer W (1982) Reactivation of Rickettsia rickettsii in Dermacentor andersoni ticks: an ultrastructural analysis. Infect Immun 37: 779-785.

7. Konkel ME, Tilly K (2000) Temperature-regulated expression of bacterial virulence genes. Microbes Infect 2: 157-166.

8. Conway T, Schoolnik GK (2003) Microarray expression profiling: capturing a genome-wide portrait of the transcriptome. Mol Microbiol 47: 879-889.

9. Rovery C, La MV, Robineau S, Matsumoto K, Renesto P, et al. (2005) Preliminary transcriptional analysis of spoT gene family and of membrane proteins in Rickettsia conorii and Rickettsia felis. Ann N Y Acad Sci 1063: 79-82.

10. Audia JP, Patton MC, Winkler HH (2008) DNA microarray analysis of the heat shock transcriptome of the obligate intracytoplasmic pathogen Rickettsia prowazekii. Appl Environ Microbiol 74: 7809-7812.

11. Dreher-Lesnick SM, Ceraul SM, Rahman MS, Azad AF (2008) Genome-wide screen for temperature-regulated genes of the obligate intracellular bacterium, Rickettsia typhi. BMC Microbiol 8: 61.

12. Ellison DW, Clark TR, Sturdevant DE, Virtaneva K, Hackstadt T (2009) Limited transcriptional responses of Rickettsia rickettsii exposed to environmental stimuli. PLoS One 4: e5612.

13. Pinter A, Labruna MB (2006) Isolation of Rickettsia rickettsii and Rickettsia bellii in cell culture from the tick Amblyomma aureolatum in Brazil. Ann N Y Acad Sci 1078: 523529.

14. Labruna MB, Ogrzewalska M, Martins TF, Pinter A, Horta MC (2008) Comparative susceptibility of larval stages of Amblyomma aureolatum, Amblyomma cajennense, and Rhipicephalus sanguineus to infection by Rickettsia rickettsii. J Med Entomol 45: 11561159.

15. Labruna MB, Ogrzewalska M, Soares JF, Martins TF, Soares HS, et al. (2011) Experimental infection of Amblyomma aureolatum ticks with Rickettsia rickettsii. Emerg Infect Dis 17: 829-834.

16. Labruna MB, Whitworth T, Horta MC, Bouyer DH, McBride JW, et al. (2004) Rickettsia species infecting Amblyomma cooperi ticks from an area in the state of Sao Paulo, Brazil, where Brazilian spotted fever is endemic. J Clin Microbiol 42: 90-98.

17. Guedes E, Leite RC, Prata MC, Pacheco RC, Walker DH, et al. (2005) Detection of Rickettsia rickettsii in the tick Amblyomma cajennense in a new Brazilian spotted feverendemic area in the state of Minas Gerais. Mem Inst Oswaldo Cruz 100: 841-845. 
18. Ellison DW, Clark TR, Sturdevant DE, Virtaneva K, Porcella SF, et al. (2008) Genomic comparison of virulent Rickettsia rickettsii Sheila Smith and avirulent Rickettsia rickettsii lowa. Infect Immun 76: 542-550.

19. Ballman KV, Grill DE, Oberg AL, Therneau TM (2004) Faster cyclic loess: normalizing RNA arrays via linear models. Bioinformatics 20: 2778-2786.

20. Livak KJ, Schmittgen TD (2001) Analysis of relative gene expression data using real-time quantitative PCR and the 2(-Delta Delta C(T)) Method. Methods 25: 402-408.

21. Benjamini $Y$, Hochberg Y (1995) Controlling the False Discovery Rate - a Practical and Powerful Approach to Multiple Testing. Journal of the Royal Statistical Society Series BMethodological 57: 289-300.

22. Walker DH, Feng HM, Popov VL (2001) Rickettsial phospholipase A2 as a pathogenic mechanism in a model of cell injury by typhus and spotted fever group rickettsiae. Am J Trop Med Hyg 65: 936-942.

23. Rikihisa Y, Lin M (2010) Anaplasma phagocytophilum and Ehrlichia chaffeensis type IV secretion and Ank proteins. Curr Opin Microbiol 13: 59-66.

24. Winkler HH (1976) Rickettsial permeability. An ADP-ATP transport system. J Biol Chem 251: 389-396.

25. Heinzen RA, Hayes SF, Peacock MG, Hackstadt T (1993) Directional actin polymerization associated with spotted fever group Rickettsia infection of Vero cells. Infect Immun 61: 1926-1935.

26. Li H, Walker DH (1998) rOmpA is a critical protein for the adhesion of Rickettsia rickettsii to host cells. Microb Pathog 24: 289-298.

27. Beckwith J (2013) The Sec-dependent pathway. Res Microbiol 164: 497-504.

28. Rahman MS, Simser JA, Macaluso KR, Azad AF (2005) Functional analysis of secA homologues from rickettsiae. Microbiology 151: 589-596.

29. Uchiyama T, Kawano H, Kusuhara $Y$ (2006) The major outer membrane protein rOmpB of spotted fever group rickettsiae functions in the rickettsial adherence to and invasion of Vero cells. Microbes Infect 8: 801-809.

30. Chan YG, Cardwell MM, Hermanas TM, Uchiyama T, Martinez JJ (2009) Rickettsial outermembrane protein $\mathrm{B}(\mathrm{rOmpB})$ mediates bacterial invasion through Ku70 in an actin, c$\mathrm{Cbl}$, clathrin and caveolin 2-dependent manner. Cell Microbiol 11: 629-644.

31. Uchiyama T (2012) Tropism and pathogenicity of rickettsiae. Front Microbiol 3: 230.

32. Rahman MS, Gillespie JJ, Kaur SJ, Sears KT, Ceraul SM, et al. (2013) Rickettsia typhi Possesses Phospholipase A2 Enzymes that Are Involved in Infection of Host Cells. PLoS Pathog 9: e1003399.

33. Hendrick JP, Hartl FU (1993) Molecular chaperone functions of heat-shock proteins. Annu Rev Biochem 62: 349-384.

34. La MV, Francois P, Rovery C, Robineau S, Barbry P, et al. (2007) Development of a method for recovering rickettsial RNA from infected cells to analyze gene expression profiling of obligate intracellular bacteria. J Microbiol Methods 71: 292-297.

35. Lawson JN, Johnston SA (2006) Amplification of sense-stranded prokaryotic RNA. DNA Cell Biol 25: 627-634.

36. Kang Y, Norris MH, Zarzycki-Siek J, Nierman WC, Donachie SP, et al. (2011) Transcript amplification from single bacterium for transcriptome analysis. Genome Res 21: 925935.

37. Voth DE, Broederdorf LJ, Graham JG (2012) Bacterial Type IV secretion systems: versatile virulence machines. Future Microbiol 7: 241-257.

38. Chen C, Banga S, Mertens K, Weber MM, Gorbaslieva I, et al. (2010) Large-scale identification and translocation of type IV secretion substrates by Coxiella burnetii. Proc Natl Acad Sci U S A 107: 21755-21760.

39. Gillespie JJ, Ammerman NC, Dreher-Lesnick SM, Rahman MS, Worley MJ, et al. (2009) An anomalous type IV secretion system in Rickettsia is evolutionarily conserved. PLoS One 4: e4833.

40. Mosavi LK, Cammett TJ, Desrosiers DC, Peng ZY (2004) The ankyrin repeat as molecular architecture for protein recognition. Protein Sci 13: 1435-1448.

41. Voth DE (2011) ThANKs for the repeat: Intracellular pathogens exploit a common eukaryotic domain. Cell Logist 1: 128-132.

42. Pan X, Luhrmann A, Satoh A, Laskowski-Arce MA, Roy CR (2008) Ankyrin repeat proteins comprise a diverse family of bacterial type IV effectors. Science 320: 1651-1654. 
43. Tokarz R, Anderton JM, Katona LI, Benach JL (2004) Combined effects of blood and temperature shift on Borrelia burgdorferi gene expression as determined by whole genome DNA array. Infect Immun 72: 5419-5432.

44. Blanc G, Ngwamidiba M, Ogata H, Fournier PE, Claverie JM, et al. (2005) Molecular evolution of rickettsia surface antigens: evidence of positive selection. Mol Biol Evol 22: 2073-2083.

45. Martinez JJ, Seveau S, Veiga E, Matsuyama S, Cossart P (2005) Ku70, a component of DNA-dependent protein kinase, is a mammalian receptor for Rickettsia conorii. Cell 123: 1013-1023.

46. Graca-Souza AV, Maya-Monteiro C, Paiva-Silva GO, Braz GR, Paes MC, et al. (2006) Adaptations against heme toxicity in blood-feeding arthropods. Insect Biochem Mol Biol 36: 322-335.

47. Dzik JM (2010) The ancestry and cumulative evolution of immune reactions. Acta Biochim Pol 57: 443-466.

48. Pereira LS, Oliveira PL, Barja-Fidalgo C, Daffre S (2001) Production of reactive oxygen species by hemocytes from the cattle tick Boophilus microplus. Exp Parasitol 99: 66-72.

49. Stroher E, Millar AH (2012) The biological roles of glutaredoxins. Biochem J 446: 333-348.

50. Park S, You X, Imlay JA (2005) Substantial DNA damage from submicromolar intracellular hydrogen peroxide detected in Hpx- mutants of Escherichia coli. Proc Natl Acad Sci U S A 102: 9317-9322.

\section{Figures}

Figure 1. Boxplot representation of $\boldsymbol{R}$. rickettsii load in $\boldsymbol{A}$. aureolatum adult females. The bacterial load in unfed ticks incubated at either $25^{\circ} \mathrm{C}(\mathrm{G} 1)$ or $35^{\circ} \mathrm{C}(\mathrm{G} 2)$ or fed on dogs (G3) was determined by qPCR using specific primers and a TaqMan probe for gltA. The medians are represented by thicker black lines. Outliers are represented by empty circles. ${ }^{*} p<0.001$, Wilcoxon test.

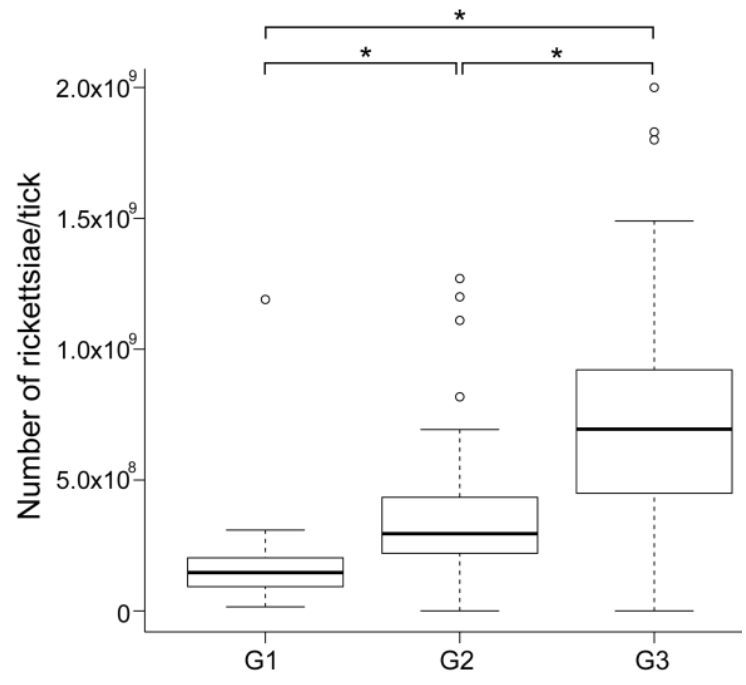


Figure 2. Functional classification of $R$. rickettsii genes modulated by exposure to a $10^{\circ} \mathrm{C}$ increase in incubation temperature $(A)$ or to blood feeding $(B)$.
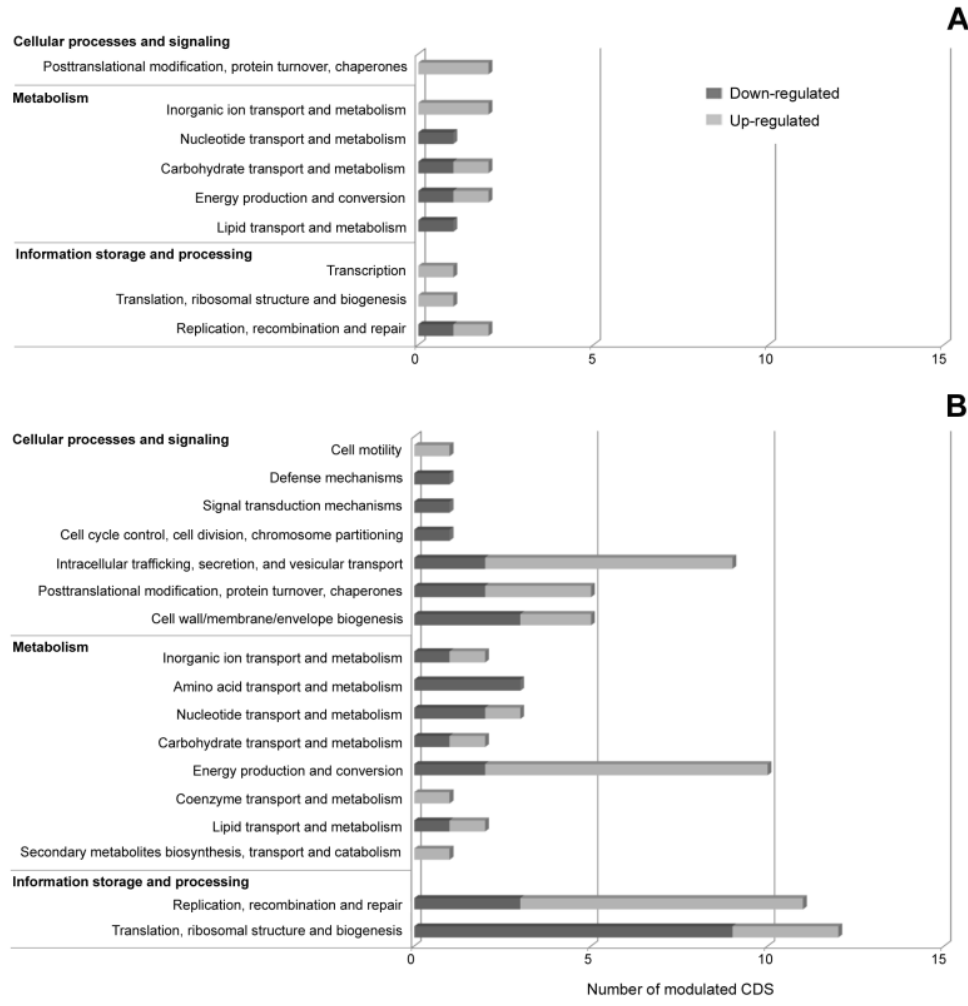

Figure 3. Location and orientation of genes encoding T4SS components repressed $(A)$ or induced $(B)$ by blood feeding in the $\boldsymbol{R}$. rickettsii genome. Black arrows represent genes modulated in two biological replicates and grey arrows genes modulated in only one biological replicate in microarray experiments. The modulation of the ATPase VirB4 (A1G_00815; white arrow) was not observed.
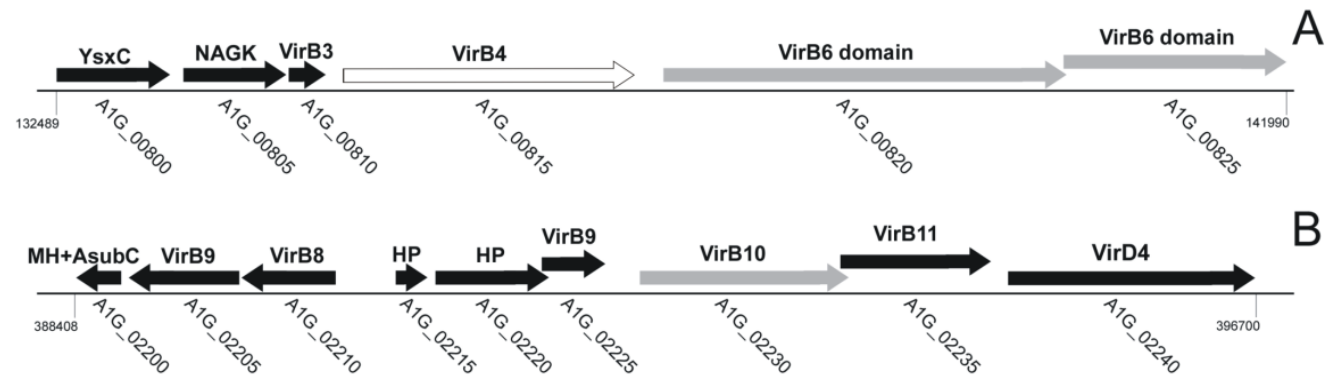
Table 1. Transcript levels of selected genes of $R$. rickettsii analyzed by microarrays and high-throughput microfluidic RT-qPCR.

\begin{tabular}{|c|c|c|c|c|c|c|c|}
\hline \multicolumn{3}{|l|}{ Temperature shift } & \multicolumn{3}{|l|}{ Blood feeding } & \multicolumn{2}{|c|}{$\begin{array}{l}\text { Temperature shift }+ \\
\text { Blood feeding }\end{array}$} \\
\hline Microarray & RT-qPCR & & Microarray & RT-qPCR & & RT-qPCR & \\
\hline $\begin{array}{lr}\text { Fold } & \text { change } \\
\text { (replicate } & 1 ; \\
\text { replicate 2) } & \end{array}$ & Fold change & $p$-value & $\begin{array}{lr}\text { Fold } & \text { change } \\
\text { (replicate } & \text {;; } \\
\text { replicate 2) }\end{array}$ & Fold change & $p$-value & Fold change & $p$-value \\
\hline ND & -1.67 & 0.0000 & $-2.33(-2.39 ;-2.27)$ & -4.76 & 0.0000 & -8.33 & 0.0000 \\
\hline ND & NS & & $-1.96(-1.91 ;-2.02)$ & -2.17 & 0.0000 & -2.13 & 0.0000 \\
\hline ND & NS & & $-1.73(-1.62 ;-1.83)$ & -2.70 & 0.0000 & -2.22 & 0.0000 \\
\hline ND & 1.41 & 0.0018 & $-2.46(-2.62 ;-2.29)$ & -4.00 & 0.0000 & -2.86 & 0.0000 \\
\hline ND & NS & & $-1.79(-1.79 ;-1.78)$ & -2.94 & 0.0000 & -2.70 & 0.0000 \\
\hline ND & 1.45 & 0.0016 & $-1.98(-2.07 ;-1.89)$ & -2.78 & 0.0000 & -1.92 & 0.0000 \\
\hline ND & 1.43 & 0.0080 & $-5.41(-5.66 ;-5.15)$ & -12.5 & 0.0000 & -8.33 & 0.0000 \\
\hline ND & NS & & $2.19(2.30 ; 2.09)$ & 1.36 & 0.0000 & 1.29 & 0.0012 \\
\hline ND & $-1,25$ & 0.0019 & $2.68(3.12 ; 2.23)$ & 1.93 & 0.0000 & 1.54 & 0.0000 \\
\hline ND & -1.27 & 0.0045 & $2.38(2.42 ; 2.35)$ & 1.56 & 0.0000 & NS & \\
\hline ND & NS & & $1.72(1.69 ; 1.76)$ & 1.55 & 0.0000 & 1.81 & 0.0000 \\
\hline ND & -1.35 & 0.0002 & $1.68(1.70 ; 1.66)$ & 2.00 & 0.0000 & 1.49 & 0.0000 \\
\hline ND & -1.19 & 0.0196 & $1.83(1.72 ; 1.94)$ & 1.64 & 0.0000 & 1.38 & 0.0000 \\
\hline ND & NS & & $1.67(1.59 ; 1.75)$ & 1.84 & 0.0000 & 2.06 & 0.0000 \\
\hline ND & NS & & $-2.06(-2.18 ;-1.93)$ & -2.78 & 0.0000 & -2.33 & 0.0000 \\
\hline $1.53(1.53 ; 1.53)$ & 1.86 & 0.0000 & $-2.69(-2.52 ;-2.87)$ & -4.35 & 0.0000 & -2.27 & 0.0000 \\
\hline$-1.79(-1.99 ;-1.60)$ & -1.96 & 0.0000 & ND & 1.40 & 0.0002 & 0.72 & 0.0000 \\
\hline
\end{tabular}

\section{Gene ID Annotation}

A1G_00295 cell surface antigen-like protein Sca10

A1G_00515 ADP,ATP carrier protein

A1G_00520 glycerol-3-phosphate transporter

A1G_00680 30S ribosomal protein S2

A1G_00685 elongation factor Ts

A1G_00810 type IV secretion system protein VirB3

A1G_01445 cell surface antigen-like protein Sca8

A1G_01495 ferredoxin

A1G_01525 glutaredoxin 3

A1G_02205 virB9 protein

A1G_02230 virB10 protein

A1G_02235 type IV secretion system ATPase VirB11

A1G_02240 type IV secretion system component VirD4

A1G_02555 thioredoxin peroxidase 1

A1G_02680 16S rRNA-processing protein RimM

A1G_02785 site-specific tyrosine recombinase XerD

A1G_03790 cell surface antigen

0.0000
Blood feeding

array

$0.0002 \quad 0.72$

Microarray fold-changes represent the mean of the fold-changes of two biological replicates ( 1 and 2). ND: differential expression not detected by microarrays. RT 2 PCR

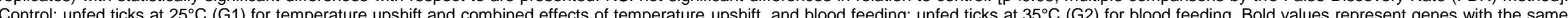
transcriptional pattern in both microarray and RT-qPCR experiments. 
Table 1 (continued).

\begin{tabular}{|c|c|c|c|c|c|c|c|c|c|}
\hline \multirow[b]{3}{*}{ Gene ID } & \multirow[b]{3}{*}{ Annotation } & \multicolumn{3}{|l|}{ Temperature shift } & \multicolumn{3}{|l|}{ Blood feeding } & \multirow{2}{*}{\multicolumn{2}{|c|}{$\begin{array}{l}\begin{array}{l}\text { Temperature } \\
\text { Blood feeding }\end{array} \\
\text { RT-qPCR } \\
\end{array}$}} \\
\hline & & Microarray & \multicolumn{2}{|l|}{ RT-qPCR } & Microarray & \multicolumn{2}{|l|}{ RT-qPCR } & & \\
\hline & & $\begin{array}{lr}\text { Fold } & \text { change } \\
\text { (replicate } & 1 ; \\
\text { replicate 2) } & \\
\end{array}$ & $\begin{array}{l}\text { Fold } \\
\text { change }\end{array}$ & $p$-value & $\begin{array}{lr}\text { Fold } & \text { change } \\
\text { (replicate } & 1 ; \\
\text { replicate 2) } & \\
\end{array}$ & Fold change & $p$-value & Fold change & $p$-value \\
\hline A1G_05315 & chaperonin GroEL & ND & 1.46 & 0.0006 & $-1.71(-1.53 ;-1.88)$ & -2.27 & 0.0000 & -1.54 & 0.0000 \\
\hline A1G_05630 & cold shock-like protein & $1.92(1.98 ; 1.87)$ & 1.36 & 0.0063 & ND & -1.96 & 0.0000 & -1.43 & 0.0002 \\
\hline A1G_05960 & bicyclomycin resistance protein & $1.57(1.60 ; 1.53)$ & 1.82 & 0.0000 & ND & -5.88 & 0.0000 & -3.33 & 0.0000 \\
\hline A1G_05625 & ATP-dependent RNA helicase RhIE & ND & NS & & $-2.87(-3.13 ;-2.62)$ & -4.76 & 0.0000 & -3.85 & 0.0000 \\
\hline A1G_06265 & ADP,ATP carrier protein & ND & 1.47 & 0.0005 & $-2.30(-2.20 ;-2.41)$ & -4.17 & 0.0000 & -2.78 & 0.0000 \\
\hline A1G_06705 & $\mathrm{NADH}$ dehydrogenase subunit $\mathrm{J}$ & ND & 1.46 & 0.0018 & $-2.02(-2.11 ;-1.93)$ & -4.17 & 0.0000 & -2.86 & 0.0000 \\
\hline A1G_06710 & $\mathrm{NADH}$ dehydrogenase subunit $\mathrm{K}$ & ND & NS & & $-4.08(-4.59 ;-3.56)$ & -12.5 & 0.0000 & -10.00 & 0.0000 \\
\hline A1G_06715 & $\mathrm{NADH}$ dehydrogenase subunit L & ND & 1.46 & 0.0124 & $-1.75(-1.97 ;-1.54)$ & -7.14 & 0.0000 & -5.00 & 0.0000 \\
\hline A1G_07470 & DNA mismatch repair protein & $-1.62(-1.69 ;-1.54)$ & -1.22 & 0.0481 & ND & 1.32 & 0.0001 & NS & \\
\hline A1G_00825 & hypothetical protein A1G_00825 & ND & 1.62 & 0.0012 & $-1.68(-1.77 ;-1.59)$ & -3.03 & 0.0000 & -1.85 & 0.0000 \\
\hline A1G_02840 & hypothetical protein A1G_02840 & ND & NS & & $-3.03(-3.30 ;-2.77)$ & -6.67 & 0.0000 & -7.14 & 0.0000 \\
\hline A1G_06350 & hypothetical protein A1G_06350 & ND & NS & & $3.57(4.12 ; 3.01)$ & 1.76 & 0.0000 & 1.86 & 0.0000 \\
\hline A1G_07480 & hypothetical protein A1G_07480 & $-2.62(-3.02 ;-2.21)$ & -1.49 & 0.0001 & $2.51(2.41 ; 2.62)$ & 2.39 & 0.0000 & 1.59 & 0.0000 \\
\hline A1G_00185 & hypothetical protein A1G_00185 & ND & NS & & $2.02(2.13 ; 1.92)$ & 2.00 & 0.0000 & 1.74 & 0.0000 \\
\hline A1G_00820 & hypothetical protein A1G_00820 & ND & 1.77 & 0.0001 & $-1.83(-1.88 ;-1.78)$ & -4.00 & 0.0000 & -2.22 & 0.0000 \\
\hline A1G_01380 & hypothetical protein A1G_01380 & ND & NS & & $2.71(2.69 ; 2.73)$ & 2.35 & 0.0000 & 1.96 & 0.0000 \\
\hline A1G_03000 & hypothetical protein A1G_03000 & ND & 2.53 & 0.0000 & $-7.2(-8.32 ;-6.07)$ & -7.14 & 0.0000 & -2.78 & 0.0000 \\
\hline A1G_06745 & hypothetical protein A1G_06745 & ND & NS & & $2.82(2.94 ; 2.69)$ & 1.69 & 0.0000 & 1.85 & 0.0000 \\
\hline
\end{tabular}


Table 2. Transcript levels of selected genes of $R$. rickettsii analyzed by high-throughput microfluidic RT-qPCR.

\begin{tabular}{|c|c|c|c|c|c|c|c|}
\hline \multirow[b]{2}{*}{ Gene ID } & \multirow[b]{2}{*}{ Annotation } & \multicolumn{2}{|c|}{ Temperature shift } & \multicolumn{2}{|l|}{ Blood feeding } & \multicolumn{2}{|c|}{$\begin{array}{l}\text { Temperature shift }+ \text { Blood } \\
\text { feeding }\end{array}$} \\
\hline & & Fold change & $p$-value & Fold change & $p$-value & Fold change & $p$-value \\
\hline A1G_00545 & stage 0 sporulation protein $\mathrm{J}$ & -1.18 & 0.0058 & -1.16 & 0.0047 & -1.39 & 0.0000 \\
\hline A1G_00890 & preprotein translocase subunit SecF & NS & & -1.43 & 0.0000 & -1.41 & 0.0000 \\
\hline A1G_01005 & preprotein translocase subunit SecE & 1.44 & 0.0000 & -1.25 & 0.0003 & 1.15 & 0.0047 \\
\hline A1G_01150 & outer membrane protein omp1 & NS & & -1.59 & 0.0000 & -1.49 & 0.0000 \\
\hline A1G_01255 & ankyrin repeat-containing protein & 1.52 & 0.0017 & -1.52 & 0.0013 & NS & \\
\hline A1G_01335 & molecular chaperone DnaK & -1.41 & 0.0003 & NS & & -1.27 & 0.0094 \\
\hline A1G_01500 & chaperone protein HscA & -1.16 & 0.0196 & -1.37 & 0.0003 & -1.61 & 0.0000 \\
\hline A1G_01505 & co-chaperone HscB & 1.70 & 0.0000 & -1.37 & 0.0001 & 1.24 & 0.0088 \\
\hline A1G_02285 & cysQ protein & 1.34 & 0.0023 & -1.27 & 0.0027 & NS & \\
\hline A1G_02675 & outer membrane assembly protein & -1.12 & 0.0351 & NS & & -1.16 & 0.0179 \\
\hline A1G_02960 & ankyrin repeat-containing protein & -1.67 & 0.0000 & -1.33 & 0.0008 & -2.22 & 0.0000 \\
\hline A1G_04625 & hemolysin & 1.21 & 0.0400 & -1.52 & 0.0003 & -1.25 & 0.0343 \\
\hline A1G_04750 & cell division protein FtsL & NS & & -1.43 & 0.0003 & -1.41 & 0.0009 \\
\hline A1G_04855 & preprotein translocase subunit SecA & -1.41 & 0.0000 & NS & & -1.25 & 0.0039 \\
\hline A1G_04935 & preprotein translocase subunit YajC & 1.17 & 0.0145 & 1.28 & 0.0001 & 1.50 & 0.0000 \\
\hline A1G_04940 & preprotein translocase subunit SecD & -1.35 & 0.0001 & NS & & -1.27 & 0.0001 \\
\hline A1G_05085 & patatin b1 precursor & NS & & -1.59 & 0.0000 & -1.85 & 0.0000 \\
\hline A1G_06030 & outer membrane protein B (cell surface antigen sca5) & NS & & 1.49 & 0.0000 & 1.56 & 0.0000 \\
\hline A1G_06165 & DNA polymerase III subunit epsilon & NS & & -1.85 & 0.0000 & -2.04 & 0.0000 \\
\hline A1G_06915 & cell surface antigen-like protein Sca13 & NS & & -1.32 & 0.0000 & -1.35 & 0.0000 \\
\hline A1G_07170 & type II citrate synthase & -1.2 & 0.0038 & NS & & -1.28 & 0.0004 \\
\hline Rrlowa_1080 & rickA Arp2/3 complex activation protein & -1.23 & 0.0227 & -2.5 & 0.0000 & -3.03 & 0.0000 \\
\hline A1G_00180 & hypothetical protein A1G_00180 & 1.18 & 0.0241 & 1.61 & 0.0000 & 1.89 & 0.0000 \\
\hline A1G_00745 & hypothetical protein A1G_00745 & NS & & -1.33 & 0.0449 & NS & \\
\hline A1G_03155 & hypothetical protein A1G_03155 & NS & & -1.75 & 0.0000 & -1.79 & 0.0000 \\
\hline A1G_04930 & hypothetical protein A1G_04930 & 1.23 & 0.0068 & 1.24 & 0.0022 & 1.53 & 0.0000 \\
\hline
\end{tabular}


Table S1. Primers used in microfluidic RT-qPCR analysis.

\begin{tabular}{|c|c|c|c|}
\hline CDS & Annotation & Sense $\left(5^{\prime}-3^{\prime}\right)$ & Antisense $\left(5^{\prime}-3^{\prime}\right)$ \\
\hline ref|NC_009882.1_:c474839-474342 & 16S rRNA-processing protein RimM & TCTITACCGACCCTGCTACA & СTCCTTTGGCATTTIGGCTA \\
\hline ref|NC_009882.1_:114829-115716 & $30 \mathrm{~S}$ ribosomal protein S2 & CGCAATTAATGAAGCGGTAAA & ATCATCATTACCCGGAATCG \\
\hline ref|NC_009882.1_:75811-77307 & ADP,ATP carrier protein & GGCAAGCTGCTGTTGAAGT & TACAAAACCAAACGCAGGAA \\
\hline ref|NC_009882.1_:1040765-1042162 & ADP,ATP carrier protein & TCTAGCTGACTGGATGGAACG & CCAAAGCTCGGCAAGACTAT \\
\hline ref|NC_009882.1_:c815948-815700 & ankyrin repeat-containing protein & ATACCTITGCATGCGGTTG & TGCGTGATATCAGCACCAT \\
\hline reff|NC_009882.1_:c12474-12022 & ankyrin repeat-containing protein & ATCAATCCGATGAGGATGGT & AGCCTCGTCAGACATCTTGG \\
\hline ref|NC_009882.1_:c11968-11702 & ankyrin repeat-containing protein & TATTAAGCTGCTGCCACCTG & ATTCCCTTACCTCGGCAAAT \\
\hline ref|NC_009882.1_514056-514307 & ankyrin repeat-containing protein & GGCAGAGCGGTTAATAAAACA & TITAAAGCGCTGTAATCTGTCAA \\
\hline reff|NC_009882.1_513850-514026 & ankyrin repeat-containing protein & CCCAGAAAACAAAAAGTACCATACA & CTCTAAAGCAGTATCACCATTCTCA \\
\hline reff|NC_009882.1_:232567-232908 & ankyrin repeat-containing protein & ATGATGCTAGCCGCAGAAAG & AGGGAAGTCATTCCGGTTT \\
\hline ref|NC_009882.1_:c720461-719856 & ATP-dependent Clp protease proteolytic subunit & CGAGAAGGGGATGCGTTAT & AGGGTTTCTTGAGCATGGATT \\
\hline ref|NC_009882.1_:616905-619217 & ATP-dependent protease La & AAAGCTCCAAATTGCCAGA & ATCCAAAAGTGCCATCTCG \\
\hline ref|NC_009882.1_:c943449-942217 & ATP-dependent RNA helicase RhIE & GTCAGCGTCAACGTGAAAGA & GAGGAATATCAAGCCCACGA \\
\hline ref|NC_009882.1_:991314-992378 & bicyclomycin resistance protein & GGGATATCATCGGTTGCAG & AGGGCAATAGTGCCGTTTA \\
\hline ref|NC_009882.1_:c803667-803269 & cell division protein FtsL & ACTTTGGCCGGCTAGATTGG & TATATTGGGCCCTAACGGATCTT \\
\hline reff|NC_009882.1_:652833-655895 & cell surface antigen & TAACCAACCACTGCAACCTG & TTGCATGCTGCCTGATAAAG \\
\hline reff|NC_009882.1_:262509-262940 & cell surface antigen-like protein Sca8 & GCTCCTGTACTTAACGGTGCT & TGCTCGTTACGTCCTGTTC \\
\hline ref|NC_009882.1_:45976-46317 & cell surface antigen-like protein Sca10 & CCGGGACTACATGCTTCTGT & TGCTGCTAATTGTAGTGTTCTCAA \\
\hline ref|NC_009882.1_:c1153524-1153240 & cell surface antigen-like protein Sca13 & GCAGTACTTCAAAAGTGGGTGAT & TCCTTAAATTTTATGTCGCCAAC \\
\hline ref|NC_009882.1_:c271743-269956 & chaperone protein HscA & TCTCAATACTCCGGCACTTTाT & TGCAATTTCAGGGACTCTCA \\
\hline reffNC_009882.1_:c901984-901727 & chaperonin GroEl & TाTTGGAGCCATCCATTACC & GGTCGGCGACTATCCATATCT \\
\hline ref|NC_009882.1_:c272234-271734 & co-chaperone HscB & ATGCCTTAAAGCGTGCTGA & GCTTAATTCTAGCGGCGAAA \\
\hline ref|NC_009882.1_c944176-943964 & cold shock-like protein & TाTGTACACAAATCAGCCGTAGA & CAGCATAGGCTITCCTTGC \\
\hline ref|NC_009882.1_:402739-403515 & cys Q protein & TCGA TCCTATTGATGGGACA & ATATCAAGCCGATGGTTGG \\
\hline ref|NC_009882.1_c1249026-1247194 & DNA mismatch repair protein & ССTAACTGCGTCAAATGGAAA & CGTCCAAATAAGCGTTCGAT \\
\hline ref|NC_009882.1_:1028222-1028911 & DNA polymerase Ill subunit epsilon & ACAACAAGGTCATCGAATCGT & AGCCTCAAACGGCATATCTC \\
\hline ref|NC_009882.1_:1236834-1237097 & DNA-damage-inducible protein $\mathrm{J}$ & AGCAGCTTTAGTGCTTGCTG & GTGGTTCAAACGGCAATG \\
\hline ref|NC_009882.1_:115915-116844 & elongation factor Ts & CGGTGCAGGTATGATGGAT & TGCAGCAGCAGCTAAACC \\
\hline ref|NC_009882.1_:c1181808-1181458 & ferredoxin & CACCGGGGTAATAGAATGG & ATTTATCGGCATCAGGCAAA \\
\hline ref|NC_009882.1_:275087-275395 & glutaredoxin 3 & AATATGCATGTTGGCGGTTG & CAGCAGGTGCAGTCGTCTT \\
\hline ref|NC_009882.1_:77503-78798 & glycerol-3-phosphate transporter & TGCAAATGCAGGCTTACAAA & CGCGACGACCTTGAAATAGT \\
\hline ref|NC_009882.1_:361975-362622 & heme exporter protein B & TGGAAGACGGAAGCTTAGAGT & AACAAAAACCAGCCCTATCG \\
\hline ref|NC_009882.1_:c783932-783177 & hemolysin & GTAGTAGCACCGGCGGTाT & AGGATGAAGTCCGCCATAAC \\
\hline ref|NC_009882.1_:c1044404-1043505 & hemolysin C & AATTGCAGCTCCTTCTATGAAA & AAACCGTCAGTACCGCCATA \\
\hline ref|NC_009882.1_577205-579712 & leucyl-tRNA synthetase & TGGCAGTACATTGGCAAGA & CATGGATTTACCGGAAGGGA \\
\hline ref|NC_009882.1_500770-502338 & Iysyl-tRNA synthetase & CCTGAAATGGTGGCACAGTA & GAGCGAAGCTTTGCATTCAT \\
\hline ref|NC_009882.1_c968241-966715 & methionyl-tRiNA synthetase & GCGTITCATGCCGTCTATT & AАTTTCTGCCCATCATTCG \\
\hline ref|NC_009882.1_:c248307-246424 & molecular chaperone DnaK & ATTGAAACTCTTGGCGGTGT & TIACGGCATGCTGGTTATCA \\
\hline ref|NC_009882.1_:1117766-1118383 & NADH dehydrogenase subunit $J$ & TCAGTAGCGTATGCGTTGTCTT & TாCTGCTCCAAGCAAAATCA \\
\hline ref|NC_009882.1_:1118376-1118690 & NADH dehydrogenase subunit $\mathrm{K}$ & TGAGTAATGCTGCTGGAGTT & GGCAGCTGCTACGGTTAAGA \\
\hline ref|NC_009882.1_:1118690-1120663 & NADH dehydrogenase subunit $L$ & ACCATGGATTGAGGTTGGAA & TGACACCCATGTTACGGCTA \\
\hline ref|NC_009882.1_:c373645-373484 & outer memberane protein rOmpA & AGATTTCGGTACGTGGGCTA & CCGACAGTACTGCTGGTTGA \\
\hline ref|NC_009882.1_c473994-471502 & outer membrane assembly protein & TAGATGCTTCACCTGCCACA & TAGGCGGTAAATCCGCAATA \\
\hline ref|NC_009882.1_:c1007464-1002500 & outer membrane protein B (cell surface antigen sca5) & TGGTGCAGGATTACAAGGAA & AGTAGTACCGCCGCCTAAAA \\
\hline ref|NC_009882.1_c214853-212547 & outer membrane protein omp 1 & TAGTCGGTACCGGGAAACTG & CGCCAAGTGATAACTCACGA \\
\hline reff|NC_009882.1_:859725-861197 & patatin b1 precursor & CGATTITACTGGAGGGACCA & TTGCGCTGCACTGAATAAAG \\
\hline ref|NC_009882.1_:c819688-816968 & preprotein translocase subunit SecA & AAACGCCAAATTTCATGAGC & TACCCCGTCCTGCCATATTA \\
\hline ref|NC_009882.1_:97701-98159 & preprotein translocase subunit $\operatorname{Sec} B$ & CCGCATATTTCCGTTAATGC & ATCAATTGGAGGGCGTTGAT \\
\hline ref|NC_009882.1_:832661-834217 & preprotein translocase subunit SecD & ATCTGCGMTTGCCACTATCC & CAACGGCAAAACCTTGAT \\
\hline reff|NC_009882.1_:177150-177350 & preprotein translocase subunit SecE & TGTTGCTTCAACGTTAGTAGTGG & GCCGATATTAAGCAAAAGCTG \\
\hline ref|NC_009882.1_:156281-157207 & preprotein translocase subunit SecF & GGGGCTATGGCGATGTTAT & GTCATGCACTAAGGCGATCA \\
\hline ref|NC_009882.1_c922200-920899 & preprotein translocase subunit SecY & AATTATGGAGGCGAAGCAA & ATTAGCAAGCGTAGCAGGAAA \\
\hline ref|NC_009882.1_:832252-832677 & preprotein translocase subunit YajC & GTGCCTGCAGAAACAAATTCT & TCGTGTTTCTTGTGGACGTAA \\
\hline ref|NC_009882.1_cc1025600-1025133 & ribonuclease $\mathrm{H}$ & GTGCGCCGCTITACTACTT & CCCCGMTTGATATTITACGC \\
\hline ref|NC_009882.1_:125610-125777 & ribose-phosphate pyrophosphokinase & TGTAGAGGGCAAAAATTGCAT & CCGATAAAGCCGAATGTTCT \\
\hline ref|NC_009882.1_:125279-125629 & ribose-phosphate pyrophosphokinase & TITGGTTATGCAAGGCAAGA & CATGGTTTACTCCGAGCTTCTC \\
\hline ref|NC_010263.2_:c856717-858162 & rickA Arp2/3 complex activation protein & GGAAAATCAACCACGTCCTTC & TGCAACCGGTTTTCCTGTAT \\
\hline ref|NC_009882.1_:487702-488622 & site-specific tyrosine recombinase XerD & CGCGTTAATCCGGTCTTA & TTGAGAGCAATGTTCAAGTAACG \\
\hline ref|NC_009882.1_:82427-83287 & stage 0 sporulation protein $\mathrm{J}$ & AATTTGCCGCAGTCTATTCAA & TCGGCTATTACTTCTGCATGTTC \\
\hline ref|NC_009882.1_c450224-449622 & thioredoxin peroxidase 1 & ATTTGTCGGCAAAACTGCTC & TATCCCCTGCAGCATAATTG \\
\hline ref|NC_009882.1_:676576-677049 & translation initiation factor IF-3 & ATGCACGGCGTCGTAAATA & TACAGACAGGGGGTACAGCA \\
\hline ref|NC_009882.1_:c1203242-1201938 & type II citrate synthase & ATGGGTTTGGGTCATCGTGT & GTTGTCTAGCTGCCCGAGTT \\
\hline ref|NC_009882.1_:393787-394791 & type IV secretion system ATPase VirB11 & GAGGCCTGMTTGCGMTTAAG & TGAACCGGGATGACCTGTAT \\
\hline ref|NC_009882.1_394925-396700 & type IV secretion system component VirD4 & AGATGCAAGCTGGGCTAATC & GAACCCGTCTGCAACAAAAT \\
\hline ref|NC_009882.1_:134020-134307 & type IV secretion system protein VirB3 & GGTAACTAGACCGCCGATG & TCATAATGCCGTTATTCCAAA \\
\hline ref|NC_009882.1_:392342-393790 & virB10 protein & CGCCGGTCTTACCTCCTACT & TGCATCGCTCTCAACTAACG \\
\hline ref|NC_009882.1_c390274-389576 & virB8 protein & ACTITTGAATCACTGGCAAAAA & GGCATATCAGGTGATGTATTGG \\
\hline ref|NC_009882.1_:391686-392159 & virB9 protein precursor & TGCATITGGGCTTCAATCA & TGCCAAAGGAGTTATITCCA \\
\hline ref|NC_009882.1_:C31143-30847 & hypothetical protein A1G_00180 & TCAGGTACAATGGTAGGTGTCG & GCCGGCAATCATTCCTATTA \\
\hline ref|NC_009882.1_:C32054-31221 & hypothetical protein A1G_00185 & AAACGAATCAGGAAGCCGTA & GAAGCCGGCGTTGATACTT \\
\hline ref|NC_009882.1_:125749-125973 & hypothetical protein A1G_00745 & AGACCTCTTGGAGAACGAAGC & CGTCAATCCAGTATTCGCATC \\
\hline reff|NC_009882.1_:137058-140018 & hypothetical protein A1G_00820 & CCGGAGGTCAATGTACTCGT & CAACAGATTTGGCCCGAGAT \\
\hline reff|NC_009882.1_:140005-141990 & hypothetical protein A1G_00825 & TACACCGACTCCACCTCCTC & GAACTGCAAGACCGGAAAAA \\
\hline ref|NC_009882.1_255227-255586 & hypothetical protein A1G_01380 & GTCGGTGATCCTGTAGGTGAG & TCCCAGAACAATTATACCGACA \\
\hline ref|NC_009882.1_:418652-418861 & hypothetical protein A1G_02360 & CCGCTITCTGGGTTGTCA & AGATGGTTTGTCGGTTCGTC \\
\hline ref|NC_009882.1_:c499229-498807 & hypothetical protein A1G_02840 & TGCGTGTGGTGAGTCAATIT & TCAATAGAACGCCTTGTCGTC \\
\hline reff|NC_009882.1_:524000-524968 & hypothetical protein A1G_03000 & GCTTGGTGAATCGACCTTATT & GATAAAGGCGTATTTGCCTCA \\
\hline reff|NC_009882.1_:555321-555569 & hypothetical protein A1G_03155 & CACTAGAAGTTCCGCCTCAT & ССТСАТТАAАTТСАССТTGTCC \\
\hline reff|NC_009882.1_:c730245-729259 & hypothetical protein A1G_04280 & GGTACAATAACAGGCGGGAAT & CGCGGGAATGACATAAAGA \\
\hline ref|NC_009882.1_:832062-832241 & hypothetical protein A1G_04930 & GTTGGAAGCCAAGTAAGTGGT & СCTITGATACTTCAAGCTTTGG \\
\hline ref|NC_009882.1_:c871627-869777 & hypothetical protein A1G_05165 & TTCTGATGAAGGTACAACTCCTGT & GGCTCCTGAATGACAAGAAAA \\
\hline ref|NC_009882.1_:1020437-1020736 & hypothetical protein A1G_06100 & CACAAATGCGTCAGTCAGGT & GTAAAAAGCTTAGGCGCTTCG \\
\hline ref|NC_009882.1_:1051294-1051470 & hypothetical protein A1G_06350 & GCAAGGTGCAGGTCAAGAT & AGTTAGCTGAGCTGTGAGGACA \\
\hline ref|NC_009882.1_:c1127890-1127534 & hypothetical protein A1G_06745 & GGGTCTTGGGTGGATTGT & ACCGATGGCAACACGAAG \\
\hline ref|NC_009882.1_:1250262-1250714 & hypothetical protein A1G_07480 & TIGGAGAAGTAGGTGATTTGG & TGGTAAACTCCGCTACCTTTTT \\
\hline
\end{tabular}


Table S2. Genes of $R$. rickettsii encoding proteins with annotated function differentially expressed by the elevation of temperature.

\begin{tabular}{|c|c|c|c|c|c|}
\hline \multirow[b]{2}{*}{ Gene ID } & \multirow[b]{2}{*}{ CDS } & \multirow[b]{2}{*}{ Annotation } & \multirow[b]{2}{*}{ COG } & \multicolumn{2}{|c|}{ Fold change } \\
\hline & & & & $\begin{array}{l}\text { Biological } \\
\text { replicate } 1\end{array}$ & $\begin{array}{l}\text { Biological } \\
\text { replicate } 2\end{array}$ \\
\hline A1G_00390 & ref|NC_009882.1_:c57026-55992 & putative DNA-binding/iron metalloprotein/AP endonuclease & COG05330 & 1.98 & 1.72 \\
\hline A1G_00800 & ref|NC_009882.1_:132498-133136 & ribosome biogenesis GTP-binding protein YsxC & COG0218R & 1.87 & 1.61 \\
\hline A1G_02195 & ref|NC_009882.1_:c388225-387110 & putative monovalent cation/H+ antiporter, subunit $\mathrm{D}$ & COG0651CP & 1.68 & 1.57 \\
\hline A1G_02785 & ref|NC_009882.1_:487702-488622 & site-specific tyrosine recombinase XerD & COG4974L & 1.53 & 1.53 \\
\hline A1G_05185 & ref|NC_009882.1_:c874676-873717 & magnesium and cobalt transport protein CorA & COG0598P & 1.66 & 1.52 \\
\hline A1G_05370 & ref|NC_009882.1_:909316-909915 & grpE protein & COG05760 & 1.62 & 1.80 \\
\hline A1G_05630 & ref|NC_009882.1_:c944176-943964 & cold shock-like protein & COG1278K & 1.98 & 1.87 \\
\hline A1G_05635 & ref|NC_009882.1_:c946479-945574 & dimethyladenosine transferase & COG0030J & 1.82 & 1.50 \\
\hline A1G_05960 & ref|NC_009882.1_:991314-992378 & bicyclomycin resistance protein & COG2814G & 1.60 & 1.53 \\
\hline A1G_03490 & ref|NC_009882.1_:608404-609831 & succinate semialdehyde dehydrogenase & COG1012C & -1.79 & -1.59 \\
\hline A1G_03670 & ref|NC_009882.1_:632043-633866 & ribonucleotide-diphosphate reductase, subunit alpha & COG0209F & -1.78 & -1.89 \\
\hline A1G_03790 & ref|NC_009882.1_:652833-655895 & cell surface antigen & - & -1.99 & -1.60 \\
\hline A1G_05000 & ref|NC_009882.1_:844068-844703 & succinyl-CoA:3-ketoacid-coenzyme A transferase, subunit B & COG2057I & -2.32 & -1.95 \\
\hline A1G_07470 & ref|NC_009882.1_c1249026-1247194 & DNA mismatch repair protein & COG0323L & -1.69 & -1.54 \\
\hline
\end{tabular}




\section{Table S3. Hypothetical protein encoding genes modulated by temperature shift.}

\begin{tabular}{|c|c|c|c|c|c|}
\hline \multirow[b]{2}{*}{ CDS } & \multirow[b]{2}{*}{ Annotation } & \multirow[b]{2}{*}{ Domain identified by conserved domain analysis } & \multirow[b]{2}{*}{ E-Value } & \multicolumn{2}{|c|}{ Fold change } \\
\hline & & & & $\begin{array}{l}\text { Biological } \\
\text { replicate } 1\end{array}$ & $\begin{array}{l}\text { Biological } \\
\text { replicate } 2\end{array}$ \\
\hline ref|NC_009882.1_:289631-290197 & hypothetical protein A1G_01610 & No conserved domains identified & & 2.06 & 2.10 \\
\hline reff|NC_009882.1_:293809-293943 & hypothetical protein A1G_01635 & No conserved domains identified & & 1.75 & 1.54 \\
\hline reff|NC_009882.1_:c346202-345054 & hypothetical protein A1G_01945 & AgrB super family[cl01873] - Accessory gene regulator B & $8.85 \mathrm{e}-04$ & 2.26 & 2.12 \\
\hline reff|NC_009882.1_:c485893-485420 & hypothetical protein A1G_02765 & No conserved domains identified & & 2.29 & 1.69 \\
\hline reff|NC_009882.1_:524000-524968 & hypothetical protein A1G_03000 & Fic/DOC family & $2.07 e-22$ & 3.46 & 2.38 \\
\hline ref|NC_009882.1_:525229-525366 & hypothetical protein A1G_03005 & No conserved domains identified & & 4.29 & 2.72 \\
\hline reff|NC_009882.1_:526267-526467 & hypothetical protein A1G_03015 & No conserved domains identified & & 2.11 & 1.63 \\
\hline reff|NC_009882.1_:c535744-534896 & hypothetical protein A1G_03065 & FTR1[pfam03239] - Iron permease FTR1 family & $9.12 \mathrm{e}-60$ & 1.99 & 1.61 \\
\hline reff|NC_009882.1_:787589-787804 & hypothetical protein A1G_04655 & Transposase_20[pfam02371] - Transposase IS116/IS110/IS902 family & $6.69 \mathrm{e}-08$ & 1.84 & 1.94 \\
\hline reff|NC_009882.1_:807614-807820 & hypothetical protein A1G_04775 & DNase_IIIpfam03265] - Deoxyribonuclease II & $2.99 \mathrm{e}-03$ & 2.13 & 1.58 \\
\hline reffNC_009882.1_:875046-875333 & hypothetical protein A1G_05190 & No conserved domains identified & & 1.81 & 2.18 \\
\hline ref|NC_009882.1_:C875454-875305 & hypothetical protein A1G_05195 & No conserved domains identified & & 2.99 & 2.57 \\
\hline reff|NC_009882.1_:c947519-946632 & hypothetical protein A1G_05640 & SurA_N_3 super family[cl07813] - SurA N-terminal domain & $2.06 e-12$ & 2.23 & 1.85 \\
\hline reff|NC_009882.1_:c1026073-1025600 & hypothetical protein A1G_06150 & No conserved domains identified & & 1.76 & 1.85 \\
\hline ref|NC_009882.1_:c1193675-1193313 & hypothetical protein A1G_07135 & No conserved domains identified & & 1.99 & 1.67 \\
\hline reff|NC_009882.1_:c1226140-1225526 & hypothetical protein A1G_07280 & MFS[cd06174] - The Major Facilitator Superfamily (MFS) & $8.65 e-04$ & 1.72 & 1.69 \\
\hline reffNC_009882.1_:283121-283303 & hypothetical protein A1G_01585 & HIG_1_N[pfam04588] - Hypoxia induced protein conserved region & $2.52 \mathrm{e}-06$ & -2.24 & -1.89 \\
\hline reff|NC_009882.1_:C368094-367954 & hypothetical protein A1G_02080 & No conserved domains identified & & -1.90 & -1.52 \\
\hline reff|NC_009882.1_:443651-444028 & hypothetical protein A1G_02525 & No conserved domains identified & & -1.83 & -1.63 \\
\hline ref|NC_009882.1_:489832-490995 & hypothetical protein A1G_02795 & Lipoprotein_7[pfam01540] - Adhesin lipoprotein & $2.65 \mathrm{e}-03$ & -2.07 & -1.92 \\
\hline ref|NC_009882.1_:520257-521780 & hypothetical protein A1G_02985 & Heme_Cu_Oxidase_I super family[cl00275] - Heme-copper oxidase subunit I & $6.66 \mathrm{e}-18$ & -2.50 & -1.99 \\
\hline ref|NC_009882.1_:676096-676425 & hypothetical protein A1G_03925 & COG5346[COG5346] - Predicted membrane protein & $2.16 e-50$ & -1.70 & -1.77 \\
\hline reff|NC_009882.1_:691150-691590 & hypothetical protein A1G_04030 & COG5622[COG5622] - Protein required for attachment to host cells & $4.84 \mathrm{e}-61$ & -2.31 & -1.84 \\
\hline ref|NC_009882.1_:c748277-748155 & hypothetical protein A1G_04410 & No conserved domains identified & & -1.95 & -1.85 \\
\hline reff|NC_009882.1_:c759589-759365 & hypothetical protein A1G_04500 & No conserved domains identified & & -2.22 & -1.70 \\
\hline ref|NC_009882.1_:794728-796473 & hypothetical protein A1G_04720 & Pentapeptide[pfam00805] - Repeats (8 copies) found in many cyanobacteria & $6.05 \mathrm{e}-06$ & -1.72 & -2.05 \\
\hline reff|NC_009882.1_:c871627-869777 & hypothetical protein A1G_05165 & ANK[cd00204] - ankyrin repeats & $4.60 \mathrm{e}-03$ & -2.90 & -2.95 \\
\hline reff|NC_009882.1_:1020437-1020736 & hypothetical protein A1G_06100 & SpoT[COG0317] - Guanosine polyphosphate pyrophosphohydrolases/synthetases & $2.71 \mathrm{e}-16$ & -2.96 & -1.56 \\
\hline ref|NC_009882.1_:1115303-1116967 & hypothetical protein A1G_06690 & AdoMet_MTases[cd02440] - S-adenosylmethionine-dependent methyltransferases, class I & $2.02 \mathrm{e}-18$ & -2.72 & -2.28 \\
\hline reff|NC_009882.1_:1250262-1250714 & hypothetical protein A1G_07480 & SNF2_assoc super family[c107173] - Bacterial SNF2 helicase associated & $9.57 \mathrm{e}-03$ & -3.02 & -2.21 \\
\hline
\end{tabular}


Table S4. Genes encoding proteins with annotated function modulated by blood-feeding.

\begin{tabular}{|c|c|c|c|c|c|}
\hline \multirow[b]{2}{*}{ Gene ID } & \multirow[b]{2}{*}{ CDS } & \multirow[b]{2}{*}{ Annotation } & \multirow[b]{2}{*}{ COG } & \multicolumn{2}{|l|}{ Fold change } \\
\hline & & & & $\begin{array}{l}\text { Biological } \\
\text { replicate } 1\end{array}$ & $\begin{array}{l}\text { Biological } \\
\text { replicate } 2\end{array}$ \\
\hline A1G_00160 & ref|NC_009882.1_:c29202-28708 & F0F1 ATP synthase subunit B & COG0711C & 1.70 & 1.94 \\
\hline A1G_00175 & ref|NC_009882.1_:C30842-30114 & F0F1 ATP synthase subunit A & COG0356C & 2.30 & 2.39 \\
\hline A1G_00430 & refiNC_009882.1_:64387-64584 & site-specific DNA methylase & COG0270L & 1.78 & 2.08 \\
\hline A1G_00635 & ref|NC_009882.1_:c102248-100851 & $\operatorname{NAD}(p)$ transhydrogenase subunit beta & COG1282C & 1.89 & 1.80 \\
\hline A1G_00785 & ref|NC_009882.1_:c131143-131006 & 50 S ribosomal protein L28 & - & 1.77 & 1.77 \\
\hline A1G_01205 & ref|NC_009882.1_:225568-225900 & DNA-binding protein HU & COG0776L & 3.09 & 3.48 \\
\hline A1G_01215 & ref|NC_009882.1_:227060-228409 & signal recognition particle protein & COG0541U & 1.64 & 1.62 \\
\hline A1G_01495 & ref|NC_009882.1_:c269892-269554 & ferredoxin & COG0633C & 2.30 & 2.09 \\
\hline A1G_01525 & ref|NC_009882.1_:275087-275395 & glutaredoxin 3 & COG06950 & 3.12 & 2.23 \\
\hline A1G_02025 & ref|NC_009882.1_:360525-360845 & putative monovalent cation $/ \mathrm{H}+$ antiporter subunit $\mathrm{G}$ & COG1320P & 2.04 & 1.66 \\
\hline A1G_02035 & ref|NC_009882.1_:361975-362622 & heme exporter protein B & - & 1.53 & 1.76 \\
\hline A1G_02200 & ref|NC_009882.1_:c388743-388408 & putative monovalent cation $/ \mathrm{H}+$ antiporter subunit $\mathrm{C}$ & COG1006P & 2.00 & 2.14 \\
\hline A1G_02205 & ref|NC_009882.1_:c389574-388822 & virB9 protein & COG3504U & 2.42 & 2.35 \\
\hline A1G_02210 & ref|NC_009882.1_:c390274-389576 & virB8 protein & COG3736U & 2.23 & 1.93 \\
\hline A1G_02230 & ref|NC_009882.1_:392342-393790 & virB10 protein & COG2948U & 1.69 & 1.76 \\
\hline A1G_02235 & ref|NC_009882.1_:393787-394791 & type IV secretion system ATPase VirB11 & COG0630NU & 1.70 & 1.66 \\
\hline A1G_02240 & ref|NC_009882.1_:394925-396700 & type IV secretion system component VirD4 & COG3505U & 1.72 & 1.94 \\
\hline A1G_02290 & ref|NC_009882.1_:c406315-403655 & DNA mismatch repair protein MutS & COG0249L & 1.70 & 1.76 \\
\hline A1G_02555 & ref|NC_009882.1_:c450224-449622 & thioredoxin peroxidase 1 & COG0450O & 1.59 & 1.75 \\
\hline A1G_02595 & ref|NC_009882.1_:455319-456344 & capD protein & COG1086MG & 1.54 & 1.63 \\
\hline A1G_02600 & ref|NC_009882.1_:456337-457470 & putative UDP-N-acetylglucosamine 2-epimerase & COG0381M & 1.65 & 1.77 \\
\hline A1G_02690 & ref|NC_009882.1_:477545-477787 & exodeoxyribonuclease VII small subunit & COG1722L & 1.64 & 2.91 \\
\hline A1G_03140 & ref|NC_009882.1_:c552178-551231 & cytochrome c oxidase polypeptide II & COG1622C & 1.54 & 1.58 \\
\hline A1G_03350 & ref|NC_009882.1_:587602-588060 & SsrA-binding protein & COG06910 & 2.12 & 2.06 \\
\hline A1G_03685 & ref|NC_009882.1_:634696-635682 & ribonucleotide-diphosphate reductase subunit beta & COG0208F & 1.61 & 1.71 \\
\hline A1G_03930 & ref|NC_009882.1_:676576-677049 & translation initiation factor IF-3 & COG0290J & 1.84 & 1.86 \\
\hline A1G_03935 & ref|NC_009882.1_:677195-678433 & branched-chain alpha-keto acid dehydrogenase subunit E2 & COG0508C & 1.52 & 1.54 \\
\hline A1G_03945 & ref|NC_009882.1_:679794-681557 & single-stranded-DNA-specific exonuclease RecJ & COG0608L & 1.50 & 1.76 \\
\hline A1G_04575 & ref|NC_009882.1_:772880-773593 & DNA repair protein $\mathrm{RecO}$ & COG1381L & 1.65 & 2.16 \\
\hline A1G_05475 & ref|NC_009882.1_:c923789-923442 & 50 S ribosomal protein L18 & COG0256J & 1.77 & 2.39 \\
\hline A1G_05485 & ref|NC_009882.1_:c924745-924347 & $30 \mathrm{~S}$ ribosomal protein S8 & COG0096J & 1.66 & 1.94 \\
\hline A1G_05670 & ref|NC_009882.1_:952076-952858 & exodeoxyribonuclease III & COG0708L & 1.59 & 1.76 \\
\hline A1G_06385 & ref|NC_009882.1_:1054896-1055495 & phosphatidylglycerophosphatase A & COG1267I & 2.16 & 1.75 \\
\hline A1G_06495 & ref|NC_009882.1_:1074289-1075014 & 3-ketoacyl-(acyl-carrier-protein) reductase & COG1028IQR & 1.57 & 1.54 \\
\hline A1G_06605 & ref|NC_009882.1_:1093598-1093933 & S-adenosylmethionine synthetase & COG0192H & 2.01 & 2.13 \\
\hline A1G_06640 & ref|NC_009882.1_:c1099203-1095658 & DNA polymerase III subunit alpha & COG0587L & 1.73 & 1.73 \\
\hline A1G_06655 & ref|NC_009882.1_:1103534-1105075 & ampG protein & - & 1.60 & 1.63 \\
\hline A1G_06670 & ref|NC_009882.1_:1107497-1109929 & virB4 protein precursor & COG3451U & 2.10 & 2.08 \\
\hline A1G_06740 & ref|NC_009882.1_:c1127546-1125516 & $\mathrm{NADH}$ dehydrogenase subunit $\mathrm{G}$ & COG1034C & 1.67 & 1.66 \\
\hline A1G_06750 & reffNC_009882.1_:c1130695-1128059 & aconitate hydratase & COG1048C & 2.21 & 1.97 \\
\hline
\end{tabular}


Table S4 (continued).

\begin{tabular}{|c|c|c|c|c|c|}
\hline \multirow[b]{2}{*}{ Gene ID } & \multirow[b]{2}{*}{ CDS } & \multirow[b]{2}{*}{ Annotation } & \multirow[b]{2}{*}{ COG } & \multicolumn{2}{|c|}{ Fold change } \\
\hline & & & & $\begin{array}{l}\text { Biological } \\
\text { replicate } 1\end{array}$ & $\begin{array}{l}\text { Biological } \\
\text { replicate } 2\end{array}$ \\
\hline A1G_00015 & ref|NC_009882.1_:1409-2158 & O-antigen export system ATP-binding protein RibE & COG1134GM & -1.76 & -1.63 \\
\hline A1G_00025 & ref|NC_009882.1_:2932-6033 & putative bifunctional glutamate synthase subunit beta/2-polyprenylphenol hydroxylase & COG0493ER & -1.60 & -1.54 \\
\hline A1G_00080 & ref|NC_009882.1_:12813-13808 & nifR3-like protein & COG0042J & -1.66 & -1.71 \\
\hline A1G_00200 & reff|NC_009882.1_:34713-34922 & recombination protein $\mathrm{F}$ & - & -1.55 & -1.64 \\
\hline A1G_00295 & reff|NC_009882.1_:45976-46317 & cell surface antigen-like protein Sca10 & - & -2.39 & -2.27 \\
\hline A1G_00390 & reff|NC_009882.1_:c57026-55992 & putative DNA-binding/iron metalloprotein/AP endonuclease & COG05330 & -2.45 & -2.22 \\
\hline A1G_00395 & ref|NC_009882.1_:c58403-57210 & acyl-CoA desaturase 1 & COG1398I & -2.13 & -1.64 \\
\hline A1G_00515 & ref|NC_009882.1_:75811-77307 & ADP,ATP carrier protein & COG3202C & -2.20 & -2.41 \\
\hline A1G_00520 & ref|NC_009882.1_:77503-78798 & glycerol-3-phosphate transporter & COG2271G & -1.62 & -1.83 \\
\hline A1G_00525 & reff|NC_009882.1_:78823-79245 & nucleoside diphosphate kinase & COG0105F & -1.69 & -1.81 \\
\hline A1G_00530 & ref|NC_009882.1_:79249-81117 & tRNA uridine 5-carboxymethylaminomethyl modification enzyme GidA & COG0445D & -2.04 & -1.81 \\
\hline A1G_00575 & reff|NC_009882.1_:c88344-88012 & Iron-sulfur cluster assembly accessory protein & COG0316S & -2.58 & -2.68 \\
\hline A1G_00680 & ref|NC_009882.1_:114829-115716 & $30 \mathrm{~S}$ ribosomal protein S2 & COG0052J & -2.62 & -2.29 \\
\hline A1G_00685 & ref|NC_009882.1_:115915-116844 & elongation factor Ts & COG0264J & -1.79 & -1.78 \\
\hline A1G_00800 & ref|NC_009882.1_:132498-133136 & ribosome biogenesis GTP-binding protein YsxC & COG0218R & -3.11 & -2.61 \\
\hline A1G_00805 & ref|NC_009882.1_:133207-134007 & acetylglutamate kinase & COG0548E & -2.32 & -1.75 \\
\hline A1G_00810 & ref|NC_009882.1_:134020-134307 & type IV secretion system protein VirB3 & COG3702U & -2.07 & -1.89 \\
\hline A1G_00880 & ref|NC_009882.1_:155386-155802 & 50 S ribosomal protein L19 & COG0335J & -2.44 & -1.88 \\
\hline A1G_00920 & ref|NC_009882.1_:161909-162601 & tRNA/rRNA methyltransferase & COG0565J & -1.95 & -1.79 \\
\hline A1G_00945 & ref|NC_009882.1_:165322-166362 & protease activity modulator HflK & COG03300 & -1.58 & -1.60 \\
\hline A1G_01390 & ref|NC_009882.1_:256639-257463 & 2,3,4,5-tetrahydropyridine-2,6-carboxylate N-succinyltransferase & COG2171E & -1.71 & -1.56 \\
\hline A1G_01440 & reff|NC_009882.1_:266435-266578 & cell surface antigen-like protein Sca8 & - & -5.66 & -5.15 \\
\hline A1G_01445 & ref|NC_009882.1_:262509-262940 & cell surface antigen-like protein Sca8 & - & -4.06 & -3.50 \\
\hline A1G_01475 & ref|NC_009882.1_:263261-263530 & cell surface antigen-like protein Sca8 & - & -6.15 & -7.11 \\
\hline A1G_01595 & ref|NC_009882.1_:283754-284281 & peptide deformylase & COG0242J & -2.32 & -1.94 \\
\hline A1G_01600 & ref|NC_009882.1_:284293-285189 & methionyl-tRNA formyltransferase & COG0223J & -1.93 & -2.00 \\
\hline A1G_01640 & ref|NC_009882.1_:c295786-294017 & multidrug resistance $A B C$ transporter ATP-binding protein & COG1132V & -1.64 & -1.65 \\
\hline A1G_01670 & ref|NC_009882.1_:299495-300343 & beta 1,4 glucosyltransferase & COG0463M & -3.08 & -2.15 \\
\hline A1G_01675 & ref|NC_009882.1_:300420-301658 & mitochondrial protease & COG0612R & -2.34 & -1.83 \\
\hline A1G_01680 & ref|NC_009882.1_:301812-302522 & phosphoribosylaminoimidazole-succinocarboxamide synthase & COG0152F & -1.93 & -1.62 \\
\hline A1G_01995 & ref|NC_009882.1_:c357123-355294 & GTP-binding protein & COG1217T & -2.23 & -2.16 \\
\hline A1G_02095 & ref|NC_009882.1_:c370213-369356 & peptide chain release factor 2 & COG1186J & -1.57 & -1.76 \\
\hline A1G_02170 & ref|NC_009882.1_:c384629-383091 & putative monovalent cation $/ \mathrm{H}+$ antiporter subunit $\mathrm{D}$ & COG0651CP & -1.63 & -2.04 \\
\hline A1G_02680 & ref|NC_009882.1_:c474839-474342 & 16S rRNA-processing protein RimM & COG0806J & -2.18 & -1.93 \\
\hline A1G_02785 & ref|NC_009882.1_:487702-488622 & site-specific tyrosine recombinase XerD & COG4974L & -2.52 & -2.87 \\
\hline A1G_02825 & ref|NC_009882.1_:496734-497573 & $A B C$ transporter permease protein & COG4120R & -1.84 & -1.95 \\
\hline A1G_02830 & ref|NC_009882.1_:497570-498292 & putative $A B C$ transporter ATP-binding protein & COG1101R & -1.79 & -2.34 \\
\hline A1G_03010 & ref|NC_009882.1_:525371-525985 & Holliday junction DNA helicase RuvA & COG0632L & -3.83 & -3.52 \\
\hline A1G_03025 & reff|NC_009882.1_:526978-528006 & Holliday junction DNA helicase RuvB & COG2255L & -1.53 & -1.63 \\
\hline A1G_03150 & ref|NC_009882.1_:554615-555154 & lipoprotein signal peptidase & COG0597MU & -2.65 & -2.19 \\
\hline
\end{tabular}


Table S4 (continued).

\begin{tabular}{|c|c|c|c|c|c|}
\hline \multirow[b]{2}{*}{ Gene ID } & \multirow[b]{2}{*}{ CDS } & \multirow[b]{2}{*}{ Annotation } & \multirow[b]{2}{*}{ COG } & \multicolumn{2}{|c|}{ Fold change } \\
\hline & & & & $\begin{array}{l}\text { Biological } \\
\text { replicate } 1\end{array}$ & $\begin{array}{l}\text { Biological } \\
\text { replicate } 2\end{array}$ \\
\hline A1G_03160 & ref|NC_009882.1_:555741-557243 & UDP-N-acetylmuramoyI-L-alanyI-D-glutamate synthetase & COG0771M & -1.88 & -1.66 \\
\hline A1G_03165 & ref|NC_009882.1_:557375-558508 & cell division protein FtsW & COG0772D & -2.31 & -2.00 \\
\hline A1G_03170 & ref|NC_009882.1_:558505-559635 & undecaprenyldiphospho-muramoylpentapeptide beta- $\mathrm{N}$ - acetylglucosaminyltransferase & COG0707M & -1.65 & -1.54 \\
\hline A1G_03250 & ref|NC_009882.1_:c568298-567279 & capM protein & COG0438M & -3.43 & -2.99 \\
\hline A1G_03280 & ref|NC_009882.1_:571571-572620 & phenylalanyl-tRNA synthetase subunit alpha & COG0016J & -1.52 & -1.50 \\
\hline A1G_03780 & ref|NC_009882.1_:651005-652540 & tRNA pseudouridine synthase $B$ & COG0130J & -1.90 & -1.96 \\
\hline A1G_04070 & ref|NC_009882.1_:c698126-696873 & ampG protein & COG2271G & -2.05 & -1.66 \\
\hline A1G_04075 & ref|NC_009882.1_:c698615-698370 & transposase & - & -2.44 & -2.34 \\
\hline A1G_04275 & ref|NC_009882.1_:c729262-728207 & porphobilinogen deaminase & COG0181H & -4.57 & -6.30 \\
\hline A1G_04285 & ref|NC_009882.1_:c730629-730501 & $\mathrm{Na}+/$ proline symporter and signal transduction histidine kinase & - & -6.29 & -5.12 \\
\hline A1G_04290 & ref|NC_009882.1_:c731081-730683 & two-component sensor histidine kinase & COG2205T & -6.91 & -5.17 \\
\hline A1G_04835 & ref|NC_009882.1_:c813871-813740 & type I site-specific restriction-modification system, $\mathrm{R}$ (restriction) subunit & - & -2.28 & -1.84 \\
\hline A1G_05020 & ref|NC_009882.1_:845765-845917 & phospho-N-acetylmuramoyl-pentapeptide-transferase & - & -2.09 & -2.68 \\
\hline A1G_05095 & ref|NC_009882.1_:991314-992378 & bicyclomycin resistance protein & - & -4.62 & -3.16 \\
\hline A1G_05210 & ref|NC_009882.1_:c881085-879286 & nitrogen regulation protein $\mathrm{ntr} Y$ & COG5000T & -2.10 & -2.52 \\
\hline A1G_05315 & ref|NC_009882.1_:c901984-901727 & chaperonin GroEL & - & -1.53 & -1.88 \\
\hline A1G_05620 & ref|NC_009882.1_:c941865-940801 & ampG protein & - & -2.43 & -1.96 \\
\hline A1G_05625 & ref|NC_009882.1_:c943449-942217 & ATP-dependent RNA helicase RhIE & COG0513LKJ & -2.98 & -2.49 \\
\hline A1G_05635 & ref|NC_009882.1_:c946479-945574 & dimethyladenosine transferase & COG0030J & -3.61 & -2.68 \\
\hline A1G_05925 & ref|NC_009882.1_:c985898-984621 & ATP-dependent protease ATP-binding subunit ClpX & COG12190 & -1.87 & -1.62 \\
\hline A1G_05935 & ref|NC_009882.1_:c987336-986650 & trans-regulatory protein ExsB & COG0603R & -2.76 & -3.02 \\
\hline A1G_05960 & ref|NC_009882.1_:c862507-862325 & bicyclomycin resistance protein & COG2814G & -1.87 & -1.58 \\
\hline A1G_06065 & ref|NC_009882.1_:c1013060-1012188 & lipid A biosynthesis lauroyl acyltransferase & COG1560M & -2.51 & -2.19 \\
\hline A1G_06070 & ref|NC_009882.1_:c1014000-1013035 & tetraacyldisaccharide 4'-kinase & COG1663M & -3.18 & -2.98 \\
\hline A1G_06075 & ref|NC_009882.1_:c1014858-1014004 & putative periplasmic protein & COG0739M & -3.36 & -4.04 \\
\hline A1G_06135 & ref|NC_009882.1_:c1024825-1024376 & $A B C$ transporter substrate binding protein & COG1463Q & -1.70 & -1.56 \\
\hline A1G_06145 & ref|NC_009882.1_:c1025600-1025133 & ribonuclease $\mathrm{H}$ & COG0328L & -2.08 & -1.82 \\
\hline A1G_06170 & ref|NC_009882.1_:1029038-1029760 & surfeit locus protein 1 & COG3346S & -2.18 & -2.05 \\
\hline A1G_06265 & ref|NC_009882.1_:1040765-1042162 & ADP,ATP carrier protein & COG3202C & -1.91 & -2.02 \\
\hline A1G_06400 & ref|NC_009882.1_:1056470-1057675 & aspartate kinase & COG0527E & -1.87 & -1.77 \\
\hline A1G_06435 & ref|NC_009882.1_:c1061573-1060332 & proline/betaine transporter & - & -3.11 & -2.65 \\
\hline A1G_06705 & ref|NC_009882.1_:1117766-1118383 & NADH dehydrogenase subunit $J$ & COG0839C & -2.11 & -1.93 \\
\hline A1G_06710 & ref|NC_009882.1_:1118376-1118690 & $\mathrm{NADH}$ dehydrogenase subunit $\mathrm{K}$ & COG0713C & -4.59 & -3.56 \\
\hline A1G_06715 & ref|NC_009882.1_:1118690-1120663 & NADH dehydrogenase subunit $L$ & COG1009CP & -1.97 & -1.54 \\
\hline A1G_07355 & ref|NC_009882.1_:c1234383-1234144 & antitoxin of toxin-antitoxin system StbD & COG2161D & -3.32 & -2.82 \\
\hline A1G_07375 & ref|NC_009882.1_:1236834-1237097 & DNA-damage-inducible protein J & COG3077L & -1.98 & -1.82 \\
\hline A1G_07380 & ref|NC_009882.1_:1237189-1237332 & addiction module toxin, RelE/StbE family protein & COG3041S & -3.13 & -2.62 \\
\hline A1G_07400 & ref|NC_009882.1_:c1240365-1239220 & succinyl-diaminopimelate desuccinylase & COG0624E & -2.61 & -2.18 \\
\hline
\end{tabular}


Table S5. Hypothetical protein encoding genes differentially expressed by blood feeding.

\begin{tabular}{|c|c|c|c|c|c|}
\hline \multirow[b]{2}{*}{ CDS } & \multirow[b]{2}{*}{ Annotation } & \multirow[b]{2}{*}{ Domain identified by conserved domain analysis } & \multicolumn{3}{|c|}{ Fold change } \\
\hline & & & E-Value & $\begin{array}{l}\text { Biological } \\
\text { replicate } 1\end{array}$ & $\begin{array}{l}\text { Biological } \\
\text { replicate } 2 \\
\end{array}$ \\
\hline ref|NC_009882.1_:c32054-31221 & hypothetical protein A1G_00185 & pfam 13462 - Thioredoxin & $9.74 \mathrm{e}-56$ & 2.13 & 1.92 \\
\hline ref|NC_009882.1_:c43779-43210 & hypothetical protein A1G_00270 & COG1678 - Putative transcriptional regulator & $2.36 \mathrm{e}-80$ & 1.54 & 1.85 \\
\hline ref|NC_009882.1_:c58861-58682 & hypothetical protein A1G_00400 & HTH super family[c100088] - Helix-turn-helix domains & $5.69 \mathrm{e}-09$ & 1.84 & 1.90 \\
\hline ref|NC_009882.1_:c96803-95487 & hypothetical protein A1G_00605 & Porin_4[pfam13609], Gram-negative porin & $3.11 \mathrm{e}-17$ & 2.76 & 2.62 \\
\hline ref|NC_009882.1_:c103121-102387 & hypothetical protein A1G_00640 & OmpW[COG3047], Outer membrane protein W & $1.89 \mathrm{e}-48$ & 1.84 & 1.81 \\
\hline reffNC_009882.1_:c122272-122108 & hypothetical protein A1G_00715 & PhdYeFM_antitox[pfam02604], Antitoxin Phd_YefM, type II toxin-antitoxin system & $1.12 \mathrm{e}-14$ & 1.88 & 2.30 \\
\hline reffNC_009882.1_:122409-123413 & hypothetical protein A1G_00720 & TPR[cd00189] - Tetratricopeptide repeat domain & $1.58 \mathrm{e}-06$ & 1.53 & 2.07 \\
\hline refiNC_009882.1_c191555-190416 & hypothetical protein A1G_01045 & RPE1[TIGR01045] - Rickettsial palindromic element RPE1 domain & $1.61 \mathrm{e}-18$ & 1.83 & 2.15 \\
\hline ref|NC_009882.1_:c221811-221575 & hypothetical protein A1G_01195 & No conserved domains identified & & 1.91 & 2.38 \\
\hline reffNC 009882.1:c245095-244994 & hypothetical protein A1G 01325 & ChaB super family $[\mathrm{c} 101887 \mathrm{-ChaB}$ & $4.71 e^{-12}$ & 1.99 & 1.99 \\
\hline reffNC $009882.1: 255227-255586$ & hypothetical protein A1G 01380 & VirB2[COG3838] - Type IV secretory pathway, VirB2 components (pilins) & $2.17 \mathrm{e}-21$ & 2.69 & 2.73 \\
\hline ref|NC_009882.1_:c268466-267525 & hypothetical protein A1G_01485 & Imp[COG2358] - TRAP-type uncharacterized transport system, periplasmic component & $1.77 \mathrm{e}-111$ & 1.56 & 1.66 \\
\hline ref|NC_009882.1_:c269541-268471 & hypothetical protein A1G_01490 & MopB_Res-Cmplx1_Nad11-M[cd02774] - Mitochondrial-encoded NADH-quinone oxidoreductase/respiratory complex I & $9.49 \mathrm{e}-05$ & 2.16 & 2.12 \\
\hline ref|NC_009882.1_:283121-283303 & hypothetical protein A1G_01585 & HIG___N[pfam04588] - Hypoxia induced protein conserved region & $2.52 \mathrm{e}-06$ & 1.83 & 1.91 \\
\hline ref|NC_009882.1_:312257-312475 & hypothetical protein A1G_01755 & No conserved domain identified & & 2.92 & 2.02 \\
\hline refiNC 009882. $\cdot 390739-390918$ & hyoothetical protein A1G 02215 & No conserved domain identified & & 205 & 215 \\
\hline ref|NC_009882.1_:C421714-421487 & hypothetical protein A1G_02385 & No conserved domain identified & & 3.76 & 3.45 \\
\hline reffNC_009882.1 :436964-437104 & hypothetical protein A1G 02475 & PDDEXK 2 super family[Cl15088] - PD-(D/E)XK nuclease family transposase & $8.12 \mathrm{e}-06$ & 1.50 & 1.72 \\
\hline ref|NC_009882.1_:c551038-550655 & hypothetical protein A1G_03135 & LbH_XAT[cd03349] - Xenobiotic acyltransferase (XAT) & $1.25 \mathrm{e}-09$ & 1.68 & 1.72 \\
\hline ref|NC_009882.1_:609991-610131 & hypothetical protein A1G_03495 & COG3956 - Protein containing tetrapyrrole methyltransferase domain and MazG-like (predicted pyrophosphatase) domain & $4.87 \mathrm{e}-03$ & 1.91 & 2.71 \\
\hline refinC 009882.1 :634212-634331 & hypothetical protein A1G-03675 & No conserved domain identified & & 1.82 & 2.18 \\
\hline reffNC_009882.1_:c741051-740596 & hypothetical protein A1G_04350 & No conserved domain identified & & 1.59 & 1.61 \\
\hline ref|NC_009882.1_:782754-783182 & hypothetical protein A1G_04620 & HTH super family[cl00088] - Helix-turn-helix domains & $4.82 \mathrm{e}-39$ & 2.12 & 1.70 \\
\hline ref|NC_009882.1_:c789805-789605 & hypothetical protein A1G_04675 & No conserved domain identified & & 2.09 & 1.59 \\
\hline ref|NC_009882.1_:c790607-790365 & hypothetical protein A1G_04690 & Flu_M2 super family[Cl02903] - Influenza Matrix protein (M2) & $2.90 \mathrm{e}-03$ & 1.88 & 2.01 \\
\hline reffNC_009882.1_c791063-790797 & hypothetical protein A1G_04700 & No conserved domain identified & & 2.15 & 2.31 \\
\hline refiNC 009882.1.838905-839507 & hypothetical protein A1G 04970 & No consered domain identified & & 184 & 173 \\
\hline ref|NC_009882.1_:c889260-889108 & hypothetical protein A1G_05260 & No conserved domain identified & & 3.23 & 2.25 \\
\hline refiNC 009882.1:c913327-913094 & hypothetical protein A1G 05400 & GAS[pfam13851] - Growth-arrest specific micro-tubule binding & $4.10 \mathrm{e}-03$ & 1.90 & 2.36 \\
\hline reffNC_009882.1_:951876-952079 & hypothetical protein A1G 05665 & No conserved domain identified & & 1.92 & 1.96 \\
\hline ref|NC_009882.1_:994684-996585 & hypothetical protein A1G_05975 & ULP1[COG5160] - Protease, Ulp1 family & $4.27 \mathrm{e}-04$ & 1.61 & 1.95 \\
\hline refiNC 009882.1: $1051294-1051470$ & hypothetical protein A1G 06350 & COG5510 - Predicted small secreted protein & $4.88 \mathrm{e}-15$ & 4.12 & 3.01 \\
\hline reffNC 009882.1 : c1062928-1062575 & hypothetical protein A1G 06455 & HTH 25[pfam13413] - Helix-turn-helix domain & $1.10 \mathrm{e}-20$ & 2.06 & 1.61 \\
\hline ref|NC_009882.1_:c1071820-1071686 & hypothetical protein A1G_06480 & PRK14995[PRK 14995] - methyl viologen resistance protein SmvA & $4.84 \mathrm{e}-04$ & 1.88 & 2.08 \\
\hline ref|NC_009882.1_:c1072517-1072290 & $\begin{array}{l}\text { hypothetical protein A1G_06485 } \\
\text { het }\end{array}$ & No conserved domain identified & & 1.55 & 1.85 \\
\hline ref|NC_009882.1_:1079986-1080216 & hypothetical protein A1G_06525 & No conserved domain identified & & 2.14 & 2.08 \\
\hline reffNC 009882.1:1100886-1103396 & hypothetical protein A1G 06650 & AsmA 2[pfam 13502] - AsmA-like C-terminal region & $2.31 \mathrm{e}-07$ & 1.75 & 2.04 \\
\hline ref|NC_009882.1_:c1127890-1127534 & hypothetical protein A1G_06745 & COG3671[COG3671] - Predicted membrane protein & $3.91 \mathrm{e}-67$ & 2.94 & 2.69 \\
\hline refiNC 009882.1 :c1233873-1233787 & hypothetical protein A1G 07345 & Transpeptidase super family[cl01009] - Penicillin binding protein transpeptidase domain & $1.05 \mathrm{e}-05$ & 1.96 & 2.10 \\
\hline refiNC 009882.1:1250262-1250714 & hypothetical protein A1G 07480 & SNF2 assoc super family[cl07173] - Bacterial SNF2 helicase associated & $9.57 \mathrm{e}-03$ & 2.41 & 2.62 \\
\hline refiNC_009882.1_:c462530-461532 & hypothetical protein A1G_02620 & AcrA[COG0845] - Membrane-fusion protein & $1.20 \mathrm{e}-31$ & $\begin{array}{l}-1.41 \\
-1.75\end{array}$ & $\begin{array}{l}2.02 \\
-1.67\end{array}$ \\
\hline ref|NC_009882.1_:c6316-6077 & hypothetical protein A1G_00030 & MazF[COG2337] - Growth inhibitor & $4.40 \mathrm{e}-15$ & -2.39 & -2.17 \\
\hline ref|NC_009882.1_:13826-14749 & hypothetical protein A1G_00085 & CE4_RC0012_like[cd10963] - Putative catalytic NodB homology domain of uncharacterized protein from Rickettsia conorii & $8.64 \mathrm{e}-114$ & -1.98 & -1.68 \\
\hline reffNC 009882.1:32218-32739 & hypothetical protein A1G 00190 & COG1329 - Transcriptional regulators, similar to M xanthus CarD & $2.39 \mathrm{e}-72$ & -2.88 & -2.59 \\
\hline reffNC 009882.1:87774-87914 & hypothetical protein A1G 00570 & No conserved domain identified & & -1.64 & -1.9 \\
\hline reffNC_009882.1_c100796-100236 & hypothetical protein A1G_00630 & No conserved domain identified & & -2.16 & -1.79 \\
\hline reffNC 009882.1: $: 117318-117707$ & hypothetical protein A1G 00690 & No conserved domain identified & & -1.85 & -2.37 \\
\hline refiNC 009882.1: $137058-140018$ & hypothetical protein A1G 00820 & VirB6[COG3704] 33499 no Type IV secretory pathway, VirB6 components & 3.76e-101 & -1.88 & -1.78 \\
\hline ref|NC_009882.1_:140005-141990 & hypothetical protein A1G_00825 & VirB6[COG3704] - Type IV secretory pathway, VirB6 components & $9.75 \mathrm{e}-103$ & -1.77 & -1.59 \\
\hline reffNC 009882.1 : c199098-196984 & hypothetical protein A1G 01070 & polC[PRK00448], DNA polymerase III PoIC; Validated & $5.33 \mathrm{e}^{-03}$ & -1.65 & -1.69 \\
\hline
\end{tabular}


Table S5 (continued).

\begin{tabular}{|c|c|c|c|c|c|}
\hline \multirow[b]{2}{*}{$\operatorname{cDS}$} & \multirow[b]{2}{*}{ Annotation } & \multirow[b]{2}{*}{ Domain identified by conserved domain analysis } & \multicolumn{3}{|c|}{ Fold change } \\
\hline & & & E-Value & $\begin{array}{l}\text { Biological } \\
\text { replicate 1 }\end{array}$ & $\begin{array}{l}\text { Biological } \\
\text { replicate 2 }\end{array}$ \\
\hline $\begin{array}{l}\text { reff|NC_009882.1_:210439-210642 } \\
\end{array}$ & hypothetical protein A1G_01135 & DUF2674[pfam 10879] - Protein of unknown function (DUF2674) & $2.24 \mathrm{e}-46$ & -1.96 & -1.89 \\
\hline reffNC_009882.1_:263542-263811 & hypothetical protein A1G_01450 & No conserved domain identified & & -5.74 & -5.90 \\
\hline ref|NC_009882.1:c264827-264525 & hypothetical protein A1G 01455 & No conserved domain identified & & -4.24 & -3.88 \\
\hline ref|NC_009882.1_:285406-285849 & hypothetical protein A1G 01605 & No conserved domain identified & & -2.76 & -2.19 \\
\hline reffNC_0098882.1_:289631-290197 & hypothetical protein A1G_01610 & No conserved domain identified & & -1.89 & -1.69 \\
\hline ref|NC_009882.1_:333307-333474 & hypothetical protein A1G_01880 & No conserved domain identified & & -2.49 & -2.64 \\
\hline ref|NC_009882.1_:c333827-333624 & hypothetical protein A1G_01885 & No conserved domain identified & & -1.89 & -2.03 \\
\hline ref|NC_009882.1_:c346202-345054 & hypothetical protein A1G_01945 & AgrB super family[cl01873] - Accessory gene regulator B & $8.85 \mathrm{e}-04$ & -1.87 & -1.52 \\
\hline ref|NC_009882.1_:384409-384507 & hypothetical protein A1G_02175 & PRK06588[PRK06588] - putative monovalent cation/H+ antiporter subunit D & $3.48 \mathrm{e}-23$ & -2.47 & -2.76 \\
\hline ref|NC_009882.1_:c413519-412539 & hypothetical protein A1G_02330 & Nucleotid_trans super family[Cl05288] - Nucleotide-diphospho-sugar transferase & $7.40 \mathrm{e}-04$ & -2.91 & -2.84 \\
\hline ref|NC_009882.1_:c439531-439259 & hypothetical protein A1G_02495 & flgK_ends[TIGR02492] - flagellar hook-associated protein FlgK & $9.61 \mathrm{e}-03$ & -2.35 & -1.81 \\
\hline refiNC_009882.1 :495812-496729 & hypothetical protein A1G 02820 & COG2984 - ABC-type uncharacterized transport system, periplasmic component & $1.35 \mathrm{e}-97$ & -1.66 & -1.94 \\
\hline refiNC 009882.1:c498787-498383 & hypothetical protein A1G 02835 & No conserved domain identified & & -3.73 & -3.82 \\
\hline ref|NC_009882.1_:c499229-498807 & hypothetical protein A1G_02840 & ANK[cd00204] - ankyrin repeats & $1.50 \mathrm{e}-08$ & -3.3 & -2.77 \\
\hline ref|NC_009882.1_:524000-524968 & hypothetical protein A1G_03000 & Fic[pfam02661] - Fic/DOC family & $2.07 \mathrm{e}-22$ & -8.32 & -6.07 \\
\hline ref|NC_009882.1_:525229-525366 & hypothetical protein A1G_03005 & No conserved domain identified & & -8.16 & -5.32 \\
\hline ref|NC_009882.1_526267-526467 & hypothetical protein A1G_03015 & No conserved domain identified & & -3.53 & -2.48 \\
\hline ref|NC_009882.1_:c533894-533406 & hypothetical protein A1G_03050 & BON[pfam04972] - BON domain & $3.58 \mathrm{e}-13$ & -3.04 & -2.31 \\
\hline ref|NC_009882.1_:c535744-534896 & hypothetical protein A1G_03065 & FTR1[pfam 03239] - Iron permease FTR1 family; & $9.12 \mathrm{e}-60$ & -2.81 & -2.05 \\
\hline refiNC_009882.1_:c536134-535754 & hypothetical protein A1G_03070 & Cupredoxin_1[pfam13473] - Cupredoxin-like domain & $5.13 \mathrm{e}-37$ & -2.20 & -1.73 \\
\hline ref|NC_009882.1 :c537320-536325 & hypothetical protein A1G 03075 & FKBP C C[pfam00254] - FKBP-type peptidyl-prolyl cis-trans isomerase & $4.61 \mathrm{e}-07$ & -3.65 & -2.43 \\
\hline refiNC_009882.1_:561253-561429 & hypothetical protein A1G_03195 & No conserved domain identified & & -1.54 & -1.72 \\
\hline ref|NC_009882.1_:726966-727136 & hypothetical protein A1G_04250 & PHA00670 super family[cl17051] - hypothetical protein & $3.74 \mathrm{e}-05$ & -2.08 & -2.15 \\
\hline ref|NC_009882.1_:c727231-727037 & hypothetical protein A1G_04255 & DUF4143[pfam13635] - Domain of unknown function (DUF4143) & $1.37 \mathrm{e}-06$ & -3.02 & -2.67 \\
\hline reffNC_009882.1_:c727442-727242 & hypothetical protein A1G_04260 & DUF4143[pfam13635] - Domain of unknown function (DUF4143) & $1.50 \mathrm{e}-17$ & -4.51 & -3.61 \\
\hline ref|NC_009882.1_:c727681-727544 & hypothetical protein A1G_04265 & No conserved domain identified & & -7.60 & -8.08 \\
\hline ref|NC_009882.1_:c727818-727639 & hypothetical protein A1G_04270 & P-loop_NTPase super family[Cl09099] - P-loop containing Nucleoside Triphosphate Hydrolases & $6.62 \mathrm{e}-03$ & -6.03 & -7.16 \\
\hline refiNC_009882.1_c730245-729259 & hypothetical protein A1G_04280 & Peptidase_S66[cd07025] - LD-Carboxypeptidase, a serine protease & $9.72 \mathrm{e}-51$ & -7.85 & -6.86 \\
\hline ref|NC_009882.1_:c733692-733087 & hypothetical protein A1G_04305 & ANK[cd00204] - ankyrin repeats & $6.67 \mathrm{e}-06$ & -4.91 & -3.82 \\
\hline reffNC_009882.1:767346-770225 & hypothetical protein A1G 04555 & Pentapeptide[pfam00805] - Pentapeptide repeats ( 8 copies) & $1.99 \mathrm{e}-06$ & -1.66 & -1.72 \\
\hline refiNC 009882.1:774111-774803 & hypothetical protein A1G 04585 & COG1214[COG1214] - Inactive homolog of metal-dependent proteases, putative molecular chaperone & $5.47 e-58$ & -3.52 & -3.13 \\
\hline ref|NC_009882.1_c:c814522-814355 & hypothetical protein A1G_04840 & No conserved domain identified & & -2.08 & -1.74 \\
\hline ref|NC_009882.1_:c846798-845314 & hypothetical protein A1G_05015 & No conserved domain identified & & -2.05 & -1.98 \\
\hline ref|NC_009882.1_:c868072-867395 & hypothetical protein A1G_05140 & Radical_SAM[cd01335] - Radical SAM superfamily & $8.62 \mathrm{e}-06$ & -2.16 & -2.39 \\
\hline ref|NC_009882.1_:875046-875333 & hypothetical protein A1G_05190 & & & -6.27 & -4.46 \\
\hline ref|NC_009882.1_:c875454-875305 & hypothetical protein A1G_05195 & No conserved domain identified & & -7.99 & -4.45 \\
\hline ref|NC_009882.1_:c947519-946632 & hypothetical protein A1G_05640 & SurA_N_3 super family[cl07813] - SurA N-terminal domain & $2.06 \mathrm{e}-12$ & -2.38 & -1.81 \\
\hline ref|NC_009882.1_:983971-984123 & hypothetical protein A1G_05920 & DUF2269[pfam10027] - Predicted integral membrane protein (DUF2269) & $2.72 \mathrm{e}-13$ & -2.36 & -2.02 \\
\hline reffNC_009882.1_c987677-987333 & hypothetical protein A1G 05940 & HicB[pfam05534] - bacterial HicB family of proteins & $3.58 \mathrm{e}-16$ & -2.81 & -2.59 \\
\hline refiNC 009882.1:992452-993807 & hypothetical protein A1G 05965 & MacB PCD[pfam 12704] - MacB-like periplasmic core domain & $1.44 \mathrm{e}-23$ & -2.76 & -2.23 \\
\hline ref|NC_009882.1_:c1015646-1014858 & hypothetical protein A1G_06080 & DUF519[pfam 04378] - Protein of unknown function (DUF519) possibly secreted & $3.00 \mathrm{e}-116$ & -4.90 & -4.13 \\
\hline ref|NC_009882.1_:c1026073-1025600 & hypothetical protein A1G_06150 & No conserved domain identified & & -1.98 & -1.79 \\
\hline ref|NC_009882.1_:1043231-1043452 & hypothetical protein A1G_06275 & COG4100 - Cystathionine beta-lyase family protein involved in aluminum resistance & $6.60 \mathrm{e}-03$ & -1.66 & -1.67 \\
\hline ref|NC_009882.1_cic1050287-1049916 & hypothetical protein A1G_06330 & ycf1[CHL00204] - Ycf1, Provisional & $7.56 \mathrm{e}-05$ & -2.86 & -2.52 \\
\hline ref|NC_009882.1_:c1050466-1050275 & hypothetical protein A1G_06335 & No conserved domain identified & & -4.30 & -3.32 \\
\hline ref|NC_009882.1_:c1052108-1051542 & hypothetical protein A1G_06355 & PDDEXK_2[pfam12784] - PD-(D/E)XK nuclease family transposase & $1.29 \mathrm{e}-23$ & -2.72 & -2.05 \\
\hline ref|NC_009882.1_:1117305-1117733 & hypothetical protein A1G_06700 & TH_XRE[cd00093], Helix-turn-helix XRE-family like proteins & $5.36 \mathrm{e}-08$ & -2.95 & -2.28 \\
\hline ref|NC_009882.1_c1164928-1163354 & hypothetical protein A1G_06985 & Rotamase_2[pfam 13145], PPIC-type PPIASE domain & $4.55 \mathrm{e}-11$ & -2.01 & -1.66 \\
\hline refiNC 009882.1 :c1175920-1175135 & hypothetical protein A1G 07015 & COG1835 - Predicted acyltransferases & $2.38 \mathrm{e}-18$ & -1.71 & -1.88 \\
\hline refiNC_009882.1_c1193675-1193313 & hypothetical protein A1G_07135 & No conserved domain identified & & -4.88 & -3.92 \\
\hline refiNC 009882.1:1237534-1238550 & hypothetical protein A1G 07385 & YjgP_YjgQ[pfam03739] - Predicted pe & $1.11 \mathrm{e}-59$ & -2.28 & -1.94 \\
\hline ref|NC_009882.1_:c1241293-1241123 & hypothetical protein A1G_07410 & No conserved domain identified & & -1.93 & \\
\hline reffNC_009882.1_:c1241821-1241363 & hypothetical protein A1G_07415 & HsdM[COG0286] - Type I restriction-modification system methyltransferase subunit & $1.34 \mathrm{e}-17$ & -2.43 & -2.29 \\
\hline
\end{tabular}

